\title{
DISCIPLINAMENTO DO USO E OCUPAÇÃO DO SOLO URBANO
}

VISANDO A PRESERVAÇAO DO MEIO AMBIENTE

Tese apresentada à Faculdade de Saū de Püblica da USP, para obtenção do título de Doutor em Saūde Püblica.

Orientador: Prof. Walter Engräcia de oliveira

São Paulo 1980

BIBLIOTECA 


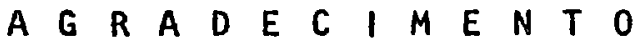

Ao Professor Walter Engräcia de Oliveira, orientadof é constante incentlvadsra

Ao Centro de Tecnologia da Universidade Fe deral do Ceará e, em especial, à Coordena ção do Curso de Pós-Graduação em Engenhá ria de Recursos Hidricos.

Ao Centro de Ciências da Saúde da Universi dade Estadual do Ceará.

Aos meus pais, irmãos e minha mulher, res ponsảveis por minha formaçäo e incentivado res permanentes. 
1. INTRODUÇÃO

2. OBJETIVO

3. MATERIAIS E METODOS

4. URBANIZAÇÃO E HEIO AMBIENTE

4.1 - 0 ecossistema urbano

4.2 - Características ambientais e a urbanizaçào

4.2.1 - Condiçōas climāticas

4.2 .2 - Topografia.

4.2 .3 - Geologia

4.2 .4 - Fatores hidrológicos

4.2.5 - Outras características ambientais

4.3 - Urbanização e poluição do meio ambiente

4.3.1 - Poluição do solo

4.3 .2 - Poluição da água

4.3.2.1 - Fontes localizadas de poluição da āgua

4.3.2.2 - Fontes não localizadas de poluiçäo da āgua

4.3.2.2.1 - Agua de escoamento superficial

4.3.2.2.2 - Água de infiltraçāo

4.3 .3 - Poluição do ar

4.3.3.1 - Emissão de poluentes

4.3.3.2 - Fatores ambientais

4.3 .4 - Poluição acūstica

4.3.5 - Poluição vịsual

5. USO DO SOLO E PRESERVAÇÃO DO MEIO AMBIENTE

5.1 - Técnicas de planejamento urbano

5.2 - Uso do solo e controle da poluição do solo

5.2 .1 - Disposição de resíduos no solo

5.2.1.1 - Disposição de resíduos sölidos

5.2 .1 .2 - Disposição de resíduos líquidos

5.2 .2 - Erosão do solo

5.3 - Uso do solo e controle da poluição da água

5.3 .1 - Capacidade da infra-estrutura onitäria existente ou projetada

5.3 .2 - Proteção do lençol freātico

5.3 .3 - Proteção de mananciais superficiais

5.3.3.1 - Controle de fontes näo localizadas

5.3 .3 .2 - Controle de fontes localizadas 
5.4 - Uso do solo e controle da poluição do ar

5.4.1 - Controle de fontes estacionärias

5.4.1.1 - Potencial de poluição

5.4 .1 .2 - Dispersão de poluentes

5.4.1.3 - Critérios para localizaçāo das fontes

5.4 .2 - Controle de fontes móveis

5.4.3 - Arranjo das edificações e áreas livres

5.5 - Uso do solo e controle da poluição acústica

5.5 .1 - Níveis aceitāveis de ruído

5.5 .2 - Medidas preventivas de controle

5.5.2.1 - Afastamento entre fonte e receptor

5.5 .2 .2 - Controle de ruídos do träfego

5.5 .2 .3 - Controle de ruídos de aeroportos

5.6 - Uso do solo e controle dos recursos de valor palsagísti co, ambiental e cultural

6. METOdOLOGIA DE PLANEJAMENTO URBANO VISANDO a PRESERVAÇÃo do MEIO AMBIENTE

6.1 - Etapas do planejamento

6.2 - Sistemätica de controle

6.2.1 - Aspectos legais e institucionais

6.2 .2 - Técnicas de controle

6.2 .3 - Aspectos econômicos

6.2.4 - Recursos humanos e educaçāo ambiental

7. RESUMO DAS PRINCIPAIS RECOMENDAÇÕES

8. REFERENCIAS BIBLIOGRAFICAS 
QUADRO TTTULO

4.1 Mudanças médias em características climáticas, causadas pela urbanização

4.2 Variaçōes de temperatura com o uso do solo urbano, em Washington, D.C. e Sheffield, Inglaterra, em dia claro de verão

4.3 Erosāo do solo em funçāo da topografia

4.4 Erosão em funçāo do uso do solo

4.5 Volume de sedimentos erodidos, por tipo de uso do solo

4.6 Persistência de alguns inseticidas clorados no solo

4.7 Populaçāo equivalente de produçāo fecal de animais, em termos de demanda bioquímica de oxigênio

4.8 Características da ägua de escoamento superficial em áreas urbanas

4.9 Concentraçōes mēdias de alguns constituintes de àguas de enxurradas, em diferentes intervalos de tempo. Northampton, Inglaterra, 1963

4.10 Distânclas e tempos de percursos alcançados por poluen tes de àguas subiterrāneas em diversas formações geolögi cas

4.11 Porcentagens de emissāo de poluentes, por fontes. Baŕa de Säo Francisco, Estados Unidos, 1975

4.12 Distribuiçāo das emissōes por tipo de fonte de poluição do ar, na regiāo da grande São Paulo, 1978

4.13 Principais poluentes do ar, suas fontes e seus efeitos

4.14 Níveis de ruidos e efeitos sobre as atividades humanas

4.15 Regra de adiçāo de decibēis, para combinação de níveís

5.1 Composiçāo de líquidos percolados em resíduos sölidos. Estados Unidos da América

5.2 Seleção do material de cobertura final de aterros san! tārios, para as diversas finalidades da mesma

5.3 Lotes mínimos em funçāo da declividade do terreno, re giāo montanhosa do èstado de Georgia, Estados Unidos 
ocupação do solo em função da declividade do terreno Condados dos Estados Unidos da Amërica

Afastamentos recomendados para äreas de infiltração de efluentes de fossa. Estados Unidos da Amërica

Dimensöes mínimas de lotes em função da infra-estrü tura sanitäria. Cidade de Carleton, Michigan, Esta dos Unidos

Proposta para dimensöes mínlmas e índice de ocupação de lotes em função da Infra-estrutura sanitäria exis tehtei Uso residencial

Proposta para dimensōes mínimas e índice de ocupação de lotes em função da infra-estrutura sanitäria exis tente. Uso comercial

5.9 Características dos principais resíduos líquidos in dustriais

5.10 Tabela de equivalentes populacionals para diferentes tipos de indüstrias

5.11 Emissão de poluentes em fontes estacionárias de poluiçāo

5.12 Classificação geral de indústrias por emissão de de terminados poluentes

5.13 Taxas de emissāo de determinados poluentes atmosféri cos, por classe de indüstria

5:14 Indústrias potencialmente grande poluidoras do ar

5:15 Indüstrias potencialmente mëdio poluidoras do ar

5.16 Industrias potencialmente pequena poluidoras do ar

5.17 Indüstrias potencialmente leve poluidoras do ar ou näo poluidoras do ar

5.18 Emissão de poluentes em veículos a gasolina, em fun ção das características de funcionamento e idade dos mesmos

5.19 Emissão de poluentes por automöveis e ônibus, por passageiro transportado, por milha, Estados Unidos da Amērica. 1960 a 1973 
QUADRO

$5: 20$

$5: 21$

5.22

7.1

7.2

7.3

7.4

7.5
Níveis de ruido recomendados para ambientes externos, em fúnção do uso do solo - Suiça

Limites de ruídos em locais de trabalho, em funçāo do perfodo de exposição diāria. Estado da Pennsyluania (E.U,A.) e Brasil

Níveis de ruídos aceitáveis para ambientes internos, de acordo com a NE-95, da Associaçăo Brasilleira de Hormas Técnicas

Resumo das recomendações visando o controle da polul ção do solo

Resumo das recomendaçöes visando o controle da polui ção da àgua

Resumo das recomendaçöes visando o controle da polui ção do ar

Resumo das recomendaçöes visando o controle da polui ção acūstica

Resumo das recomendaçōes visando a preservação dos re cursos de valor paisagístico, ambiental e cultural 


\section{FIGURA ITTULO}

4.1 0 ecossistema urbano - recursos e produtos

4.2 Consequências da urbanização sobre o ciclo hidrolögíco

4.3 Infiltração "RUNOFF" e evapo-transpiração, em função da pavimentaçăo da superfície do solo

4.4 Atividades humanas no meio urbano e a poluição ambien tal

4.5 Principais modos de ocorrência da poluição da água

4.6 Fontes de poluição da āgua, poluentes e impactos quali tativos

4.7 Alguns modos de ocorrência da poluição da àgua subter rānea

4.8 Fontes de poluiçāo do ar. Säo Paulo. 1975

4.9 Fontes de poluição do ar. Estados Unidos da América. 1975

4.10 Camadas atmosfëricas - Condições normais e inversōes

4.11 Movimento do ar em montanhas e vales

4.12 Dispersão de poluentes impedida por montanhas

4.13 "Domus de poeira". Circulaçāo do ar em uma clidade

4.14 Niveis equivalentes de ruídos em äreas residenciais de municípios da grande são paulo. 1979

5.1 Modelo de análise dos aspectos ambientais na escolha de terreno para receber resíduos

5.2 Uso do solo em funçāo da declividade do terreno. Planning Commission, Hashville - Davidson County

5.3 Proposta para ocupação do solo em função da declividą de

5.4 Ocupação do solo e o escoamento natural das águas

5.5 Zoneamento de äreas para uso de sistemas fossa/sumidou ro ou vala de infiltração

5.6 Exemplos de faixas de proteçăo de cursos d'água 
5.7 Esquema de faixas visando a preservação de cursos d'ägua

5.8 Exemplo de distribuiçäo de lotes e vias püblicas nas mar gens de cursos d'ägua

5.9 Aspectos a considerar na escolha de locals para lançamen tos de ësgotos em äreas urbahas

5:10 EXemplo de "ROSA DOS VENTOS"

5.11 Esquema de uma distrlbutçăo Gaussiana

5.12 Exemplo de curvas de concentração de poluentes a partir de uma fonte

5.13 Processo de planejamento para definiçāo da localizaçăo de atividades poluidoras do ar

5.14 Exemplo de uso do solo visando preservar a qualidade do ar em äreas sensíveis

5.15 Exemplo do uso do solo vizinho a uma via de grande movi mento de veículos

5.16 Distribuiçōes adequada e inadequada de edificações

5.17 Arranjo de äreas verdes favorecendo à circulação do ar

5.18 Exemplo de barreira contra a propagaçäo do som resultan te de träfego intenso

5.19 Propagação do som em diversas seções de vias

5.20 Curvas de "Previsão de exposição ao ruído" (N.E.F "Noise exposure fore cast")

5.21 Exemplo de disciplinamento do uso do solo nas vizinhan cas de um aeroporto, visando minimizar o impacto do rú do em äreas sensíveis

5.22 Exemplos de ocupaçōes certas e erradas do solo, em ter mos de aspectos visuais

5.23 Exemplo de um mapa indicativo de ảreas de valor palsagís tico, ambientais e histörico-cultural

6.1 Fases do planejamento do uso do solo visando a preserva ção do meio ambiente

6.2 Integraçāo entre örgāos de planejamento urbano, de con trole ambiental e de serviços püblicos 


\section{FIGURA TITULO}

613 Mêtodo da superposição de mapas para identificação de äreas ambientais sensíveis à urbanizaçăo

6.4 Exemplo esquemätico de dois parcelamentos diferentes de uma mesma ärea, mantendo-se a mesma densidade

6.5 Exemplo de parcelamento do solo considerando aspectos topogräficos e condições natural do terreno 
- trabalho tem como objetivo apresentar tëcnicas de disciplinamento do uso do solo urbano visando a preservaçäo do meio ambiente.

Inicialmente, è discutido o interrelacionamento en tre a urbanização e o meio ambiente, mostrando como as carac teristicas ambientais influem no processo de urbanização ou săo alteradas pelo mesmo. Entre as alteraçöes resultantes do desenvolvimento urbano è ressaltada a poluiçäo ambiental em suas diversas modalidades: do solo, da ägua, do ar, acústica e visual.

A seguir, săo propostas técnicas de disciplinamento do uso e ocupaçắo do solo urbano a serem apllicadas como medi das de controle preventivo destas modalidades de poluição.

Săo recomeridadas medidas de preservaçāo do meio amb ente na disposição de resíduos sōlidos e liquidos, para con trole da erosāo, como proteção da qualidade de āguas superfi cials e subterrāneas, como controle da poluição do ar e acūs tica, ou como proteçāo dos recursos de valor paisagístico, am biental e cultural.

Finalmente, é apresentada uma metodologia de planeja mento urbano visando a preservaçāo do meio ambiente, onde são discutidos os aspectos técnicos, legais, institucionais, eco nômicos e sociais do processo.

o trabalho baseia-se em pesquisa bibliogräfica e na observaçāo de programas de disciplinamento do uso do solo de cldades brasileiras e americanas. 
URBAN LAND USE CONTROL AND ENVIRONMENT PRESERVATION

This work discusses land use control techniques for urbä environment preservation.

First, the relationship between urbanization and environment is discussedd it is showed how environmental characteristics affect urbanization and how urbatization affects environment. Some kinds of environmental pollution are discussed: solid wastes disposal problems, water pollution, air pollution, noise, and visual quality impacts.

After, some land use control techniques are proposed for the preventive control of these kinds of pollution, related solid and liquid wastes disposal,erosion control, groundwater and surface water protection, air pollution and noise control. landscape, environmental and historic resources preservation.

Finaly, it is proposed an urban planning model for environmental protection. Technical, legal, economic and social aspects of planning are discussed.

This work is based on bibliographic research and observation of land use control programs of brazilian and american cities. 
E fato já comprovado e bastante discutido o processo de urbanização que ocorre em todo mundo. Acompanhado do aumento da população, hã um acentuado crescimento da população urbana, ocorrendo uma elevação na porcentagem de pessoas vivendo nas ci dades, comparada com a relativa aos habltantes do meio rural.

No Brasil ocorre, tambēm, este fenōmeno e o mesmo ca racteriza-se por uma concentraçāo de pessoas, principalmente, em algumas cidades grandes, as quais tendem a se tornar cada vez maiores.

Até o ano de 1954 a populaçäo brasileira dobrava ca da 32 anos, passando, a partir daí, a duplicar cada 24 anos. As sim, a população do Brasil, que era de 57,6 milhöes de pessoas em 1954, foi estimada em 114,6 milhöes em 1978 e deverá alcan çar 229,2 milhöes de habitantes no ano 2.002. (60)

Como dissemos, este crescimento da população acen tua-se nas àreas urbanas. Alguns dados da Fundação instituto Brasileiro de Geografia e Estatística confirmam esta afirmati va: (4)

- Em 1940, a população urbana brasileira representa va $31,2 \%$ da populaçāo total. Em 1960 foi constatada uma popula ção das cidades significando $45,1 \%$ do total. Porèm, no ano de 1970 foi maior a porcentagem de habitantes urbanos - 55,9\%, est i mando-se para 1980 uma proporção ainda maior - $63.5 \%$ da popula ção total do Brasil.

- As 9 regiōes metropolitanas brasileiras (Belēm, Cü ritiba, Fortaleza, Salvador, Porto Alegre, Belo Horizonte, Reci fe, Rio de Janeiro e São Paulo), com uma ärea terrestre igual a cerca de $0,5 \%$ da área total do país, abrigavam, em 1975, cerca de $27 \%$ de sua população.

- Os municípios com mais de um milhāo de pessoas Säo Paulo, Rio de Janeiro, Belo Horizonte, Recife,Salvador. For taleza e Porto Alegre - representando apenas cerca de $0,05 \%$ do territörio nacional, concentravam, em 1975, cerca de $17 \%$ da PO pulaçäo brasileíra.

Além das regiōes e cidades jä citadas, outras àreas urbanas brasileiras vēm apresentando elevado crescimento.

0 aumento da população e a consequente ampliação das cidades deveriam ser sempre acompanhados de um crescimento de 
toda a infra-estrutura urbana necessäria a proporcionar aos ha bitantes uma mínima condição de vida.

A ordenaçāo deste crescimento se faz necessäria, de modo que as influências que o mesmo possa ter sobre o meio amb ente não se tornem prejudiciais aos habitantes.

Infelizmente, nem sempre ocorre o que seria teorica mente desejado. 0 processo de ocupaçāo é feito sem a devida im plantaçāo da infra-estrutura necessāria. o crescimento è desor denado, sem considerar as características dos recursos naturais do meio.

As consequências deste processo inadequado de cresci mento são as já comuns em todas as cidades grandes:falta de con dições sanitärias mínimas em muitas àreas; ausência de serviços indispensāveis à vida das pessoas nas cidades; ocupaçāo de ä reas inadequadas; destruição de recursos de valor ocológico; po luição do meio ambiente; habitações em condições precärias de vida.

Tudo isto reflete-se na qualidade de vida urbana, re percutindo diretamente sobre a saüde das pessoas.

0 planejamento territorial urbano tem sido usado co mo uma forma de ordenar o crescimento das cidades, de modo a mi nimizar os problemas decorrentes da urbanização.

o disciplinamento do uso do solo urbano constitui uma importante ferramenta neste processo de ordenaçăo. 0 zonea mento, com a definição de usos preponderantes, compativeis ou indesejäveis para as diversas äreas de uma cidade, pode resuI tar numa adequada distribuiçāo de atividades, evitando-se, ao mäximo, efeitos negativos sobre o ambiente de vida de seus habi tantes.

De um modo geral, os usos do solo urbano podem ser classificados da seguinte forma:

- USOS RESIDENCIAIS

- USOS INDUSTRIAIS

- USOS COMERCIAIS

- USOS INSTITUCIONAIS (püblicos ou privados

- areas de circulação

- AREAS VAGAS (públicas ou privadas: pröprias ou im pröprias ao uso urbano)

- areas destinadas a recreaçAo 
A distribuiçāo destes usos se faz de forma variada, em funçăo das caracteristicas peculiares a cada cidade, e, nor malmente resulta em alteraçōes do ambiente natural.

Estas alterações podem ser pequenas, facilmente assi miläveis pela Natureza, cu podem acontecer em proporções maio res, provocando desequilíbrios.

Estes desequilíbrios podem resultar em alteraçōes in desejāveis (poluição) dos recursos solo, ar e ägua, com prejur zos para a população. E ísto sempre ocorre quando o disciplina mento do uso do solo é feito sem considerar aspectos ambientais, não levando em conta princípios bäsicos de saneamento.

o planejamento urbano tem sido feito considerando critérios sociais, económicos e culturais, mas muito pouco tem sido feito sob o aspecto ecológico.

os usos do solo citados anteriormente, quando feitos sem visar a preservação ambiental, resultam em problemas para os habitantes das cidades. Alguns exemplos podem ser citados:

- A localização de residências (USO ResidencIaL) em äreas com solos inadequados à utilização de sigtemas fossa -s midouro (terrenos impermeāveis ou com lençol freático elevado). pode criar muitos problemas aos seus moradores, quando näo exis tirem sistemas adequados de abastecimento de água e de afasta mento do esgoto.

- A instalação de indūstrias (USO RESIDENCIAL) sem considerar os aspectos climäticos da localidade, com certeza re sultará em problemas de poluição do ar, podendo afetar áreas ré sidenciais próximas.

- Vias de grande circulação de veículos (ÁREAS DE CIR (ULAÇAO), inadequadamente posicionadas nas proximidades de resi dēncias, podem resultar em poluição acústica. ou atmosférica, com malefícios para os seus moradores.

- A construção de um aeroporto (USO INSTITUCIONAL) nas proximidades de zonas residenciais, causarä distúrbios em termos de poluiçāo acūstica, prejudicando o sossego dos habitan tes.

Estes sāo alguns exemplos de usos incorretos do solo urbano, com efeitos indesejáveis sobre o meio ambiente, e, con sequentemente, sobre as pessoas que aí vivem.

o conhecimento e a aplicaçāo de princípios sanitāri os no disciplinamento destes usos, muito contribuirão para ate 
nuar estes efeitos.

Do mesmo modo, muitas outras téchicas de saneamento podem contribuir para um melhor disciplinamento do uso do solo urbano.

Com o crescimento acelerado de äreas urbanas, já co mentado, cada vez mais devem ser considerados os aspectos ambi entais no planejamento urbano. Os problemas de poluição podem ser minimizados ou mesmo evitados, pela simples aplicação de princípios básicos de saneamento, quando do disciplinamento do uso do solo.

A necessidade deste maior entrosamento entre os obje tivos do saneamento e os do planejamento territorial foi ressal tada por ENGRACIA DE OLIVEIRA, jä em 1964, quando afirmou:"dada a influéncia do saneamento no desenvolvimento, consequentemente se torna importante inclui-lo criteriosamente no processo de planejamento territorial". (17) 
Este trabalio pretande estudar os princípios de sa neamentó que deverāo ser considerados no disciplinamerito do uso do solo urbario, visando a preservação do melo ambienté

Apōs ưma abordagem das consequências da urbanização sobre o meio amblente, através das diversas formas de polulcăodo solo, do ar, da àgua; acüstica e visual - deverão ser estudá dos os diversos critérios ambientais a serem considerados no planejamento urbano: ou seja, serão discutidas as diversas for mas de aplicaçāo de técnicas de saneamento ao planejamento, vi sando uma melhor qualidade do ambiente urbano.

Como jä dissemos; este é o melhor caminho a ser se guido, pois visa preservar os recursos naturais, através de uma melhor distribuiça dos usos do solo nas cidades

Muitos são os critérios a serem utilizados no plane jamento territorial e este trabalho tem como objetivo discutílos sob värios aspectos, apresentando tēcnicas de disciplinamen do uso do solo urbano que levem em consideraça a aplicação dos mesmos.

A Organização Mundial da Saúde, em 1965, no seu Bo letim nümero 297, da Sërie de Relatórios Tëcnicos, preconizava que - "As normas de planejamento físico mais vālldas são as que se apoiam em normas sanitárias e que consideram, portanto, os problemas de saneamento". (63)

Deste Relatório da 0.M.S. podemos transcrever alguns outros trechos:

"São essenciais uma maior cooperação e uma coordena çăo em uma escala muito mais ampla entre planejado res e profissionais de saúde ambiental. Desde que o objetivo de ambos ē melhorar a saúde e bem-estar das pessoas, è de particular significância que os dois ponham maior ênfase na prevençāo do que na cura".

"No processo de planejamento, os planejadores e os profissionais de saúde ambiental devem trabalhar jun tos".

"Desde que o uso do solo tem sido tradicionalmente a chave para o planejamento metropolitano, deve ser considerada a sua interação com o sistema de abaste 
cimento de ägua, coleta e disposição de esgoto, dre nagem, transporte, coleta e disposição do lixo,polui ção do ar, do solo e da ägua, etc."

Neste Relatório, a Organização Mundial de Saúde res salta a necessidade de uma maior integração entre os profissio nais do planejamento e do saneamento, jả que o objetivo de am bos é o mesmo - uma melhor qualidade de vida para a população.

Infelizmente, tem sido pequano este interrelaciona mento. Ainda é insignificante a participação do profissional de saneamento no planejamento territorial. Por outro lado, medidas de planejamento poderiam ser aplicadas com maior eficācia na preservação ambiental.

Somente na ärea de preservação de recursos hídricos tem havido alguma preocupação em se relacionar o uso do solo com a qualidade da água. Alguns Estados brasileiros já possuem legislação que dispõe sobre o disciplinamento do uso do solo pá ra proteção dos recursos hídricos.

Porém, muitos outros critërios ambientais poderiam ser aplicados ao planejamento territorial, com o objetivo de preservar os recursos do ar, solo e àgua.

Neste trabalho abordaremos toda esta problemätica, procurando apresentar um roteiro de aplicaçăo dos princípios bä sicos de saneamento ao disciplinamento do uso do solo urbano.

Este trabalho poderä ser utilizado por profissionais da área de planejamento, interessados na preservaçäo ambiental, por sanitaristas cujas atividades se relacionem com o meio am biente urbano, ou, o que é mais importante, por ambos, na reali zaçāo de um trabalho conjunto em benefício da melhor qualidade de vida do homem urbano.

o trabalho foi feito visando sua aplicação ao meio ambiente urbano. No entanto, devemos destacar que não se pode isolar uma determinada ärea urbana do ambiente geral. Assim, o planejamento visando a preservação dos recursos naturais deve ser feito de forma global, analisando-se todos os fatores inter nos e externos to meio.

E importante ressaltar, também, que as propostas a presentadas devem ser consideradas como uma indicação para o es tudo aprofundado de cada ambiente. No trabalho, são recomenda dos alguns parâmetros, tais como dimensōes minimas de lotes, ta 
xas de ocupação, afastamentos, entre outros, os quais não devem ser considerados como valores rígidos, devendo serem adaptados às características próprias de cada local.

o melhor planejamento é aquele feito com base no co nhecimento detalhado do meio. Reconhecemos, no entanto, que nem sempre é possível um estudo aprofundado de todos os aspectos am bientais e, por isto, fazemos algumas proposiçōes välidas de um modo geral, as quais, se aplicadas, já contribuiräo para um pro cesso de uso e ocupaçäo dó solo com menores consequéncias dano sas ao ambiente natural.

Devemos reconhecer, ainda, que o planejamento è um processo inesgotáveijadaptável a cada ambiente em estudojAssim; acreditamos que as propostas feltas devem ser consideradas como um punto de partida para um maior detalhamento sempre que forem ser aplicados. Muitos dados precisam ainda ser levantados, novos conhecimentos devem ser adquiridos, pesquisas necessitam ser de senvolvidas, tudo isto a ser feito por técnicos de diversas for mações profissionais, de modo que seja cada vez mais aperfeiçoa do o processo de planejamento visando a preservação do meio am biente. 
Conforme já vimos, este trabalho tem como objetivo a presentar tềcnicas de disciplinamento do uso do solo urbano vi sando a preservação do meio ambiente.

Inicialmente, $\vec{e}$ feita uma discussāo sobre as conse quências da urbanização sobre o meio ambiente. A cidade è estü dada como um ecossistema, em que vários fatores ambientais se räo discutidos, verificando-se como os mesmos são afetados ou podem influir no processo de urbanização.

Como principais consequências da urbanizaçāo sobre - ambiente, são estudadas as diversas formas de poluição - do solo, do ar, da ägua, acústica e visual - observando-se as suas causas e modos de ocorrēncias.

São discutidas as tëcnicas de saneamento que podem ser aplicadas ao planejamento urbano, mostrando como as mesmas de vem ser utilizadas no controle da poluição do solo, do ar, da à gua, acústica e visual.

Finalmente, são discutidas as tëcnicas a serem apli cadas no disciplinamento do uso do solo urbano visando a preser vação do meio ambiente.

são, então, relacionados os dados, levantamentos e mapas necessärios, atividades a serem desenvolvidas, etapas do processo e aspectos institucionais.

o trabalho é desenvolvido apoiado em pesquisa em vas ta bibliografia nas áreas de planejamento territorial e sanea mento ambiental, como tambēm com base em observaçōes de progra mas de disciplinamento do uso do solo de cidades brasileiras e dos Estados Unidos da América.

Estägio realizado nos Estados Unidos da Amërica, em örgãos relacionados com o planejamento urbano e com o controle da poluição ambiental, através de programa elaborado pelo Depar tamento de Saúde, Educação e Bem-estar, daquele país, possibili tou o acompanhamento de trabalhos desenvolvidos nestas äreas.

Por outro lado, a nossa experiência profissional, xercendo atividades na Prefeitura Municipal de Fortaleza, nas äreas de planejamento, controle urbano e serviços públicos, se ja como engenhelro da Secretaria de Urbanismo e obras püblicas ou exercendo a função de Secretārio de Serviços Urbanos, foi de grande valor para a elaboraçāo deste trabalho. 
4. URBANIZAÇÃO E MEIO AMBIENTE

4.1-0 ecossistema urbano

A cidade pode ser entendida como um ecossistema, con siderando o conceito amplo do mesmo - uma unidade ambiental,den tro da qual todos os elementos e processos do ambiente são in terrelacionados e interdependentes, de modo que uma mudança em um deles resultarä em alterações em outros componentes.

Este ecossistema ë formado de dois sistemas intima mente interrelacionados: o "sistema natural", composto do meio físico e biológico (solo, vegetação, animais, habitaçōes, àgua, etc.) e o "sistema cultural", consistindo do homem e de suas a tividades. Assim, como em outros sistemas ecológicos, o homem tem a capacidade de dirigir suas açōes, utilizando o meio amb ente como fonte de matēria e energia necessärias a sua vida ou como receptor de seus produtos e resíduos.

obviamente, um meio urbano não pode funclonar como um ambiente fechado, onde o homem possa encontrar tudo que ne cessita. Assim, a cidade deve ser entendida como um sistema a berto, funcionando de forma dependente de outras partes do meio ambiente geral.

As alteraçōes introduzidas pelo homem no ambiente são sempre procedidas de forma rāpida e variada, não permitin do, muitas vezes, qua haja a recuperação normal da Natureza.

outros animais provocam alteraçōes ambientais, na bus ca de allimentos, na construção de abrigos ou na expeliçāo de de tritos. Porēm, ao contrário das mudanças causadas pelo homem, isto se processa de forma natural, lenta, e sempre do mesmo mo do, em geral, sem prejuízos ao meio ambiente.

Com o crescimento acelerado das cidades, as necess dades deste ecossistema urbano aumentam, tambëm, rapidamente, e - seu atendimento é feito a partir de modificaçōes ambientais, com prejuízos para o pröprio meio.

As necessidades de um ecossistema urbano podem ser agrupadas em duas grandes categorias: necessidades biológicas, essenciais à sobrevivência da população urbana; e requisitos culturais, necessärios ao funcionamento e crescimento da cida de. (32) 
As necessidades biolögicas do ecossistema urbano săo:

- Ar

- Agua

- Espaço

- Energía (alimento e calor)

- Abrigo

- Disposição de resíduos

As necessidades culturais säo:

- Organizafä́o política

- Sistema económico (trabalho, capital, materiais e poder)

- Tecnologia

- Transporte e comunicaçăo

- Educação e informação

- Atividades social e Intelectual - recreação, reli giăo, senso de comunidade, etc.

- Segurança

os requisitos biolögicos e culturais são obtidos e desenvolvidos no ambiente físico da cidade, o qual é formado de quatro componentes principais:

- Ambiente litológico - constituído da parte imōvel. sem vida, do planeta (formaçōes geológicas)'

- Ambiente atmosfërico

- Ambiente hidrológico

- Ambiente biolögico

Para atender as suas necessidades, o homem utilizase destes ambientes, provocando mudanças e gerando residuos.

Usando os recursos naturais, na forma de matēria e energia, o homem desenvolve suas atividades no ecossistema urba no, produzindo outras formas de energia, resíduos, bens e servi ços. (FIGURA 4.1)

Estas atividades do homem dentro do seu ecossistema urbano, resultam em modificaçōes ambientais. A urbanizaçāo ë um processo que provoca alteraçōes no meio físico.

Por outro lado, o ambiente físico pode influir sobre - processo de urbanizaçäo, contribuindo ou nāo para o seu desen volvimento. Algumas äreas säo de caracteristicas desfavoräveis à implantação de cidades. Outras, oferecem boas condiçōes, favo 


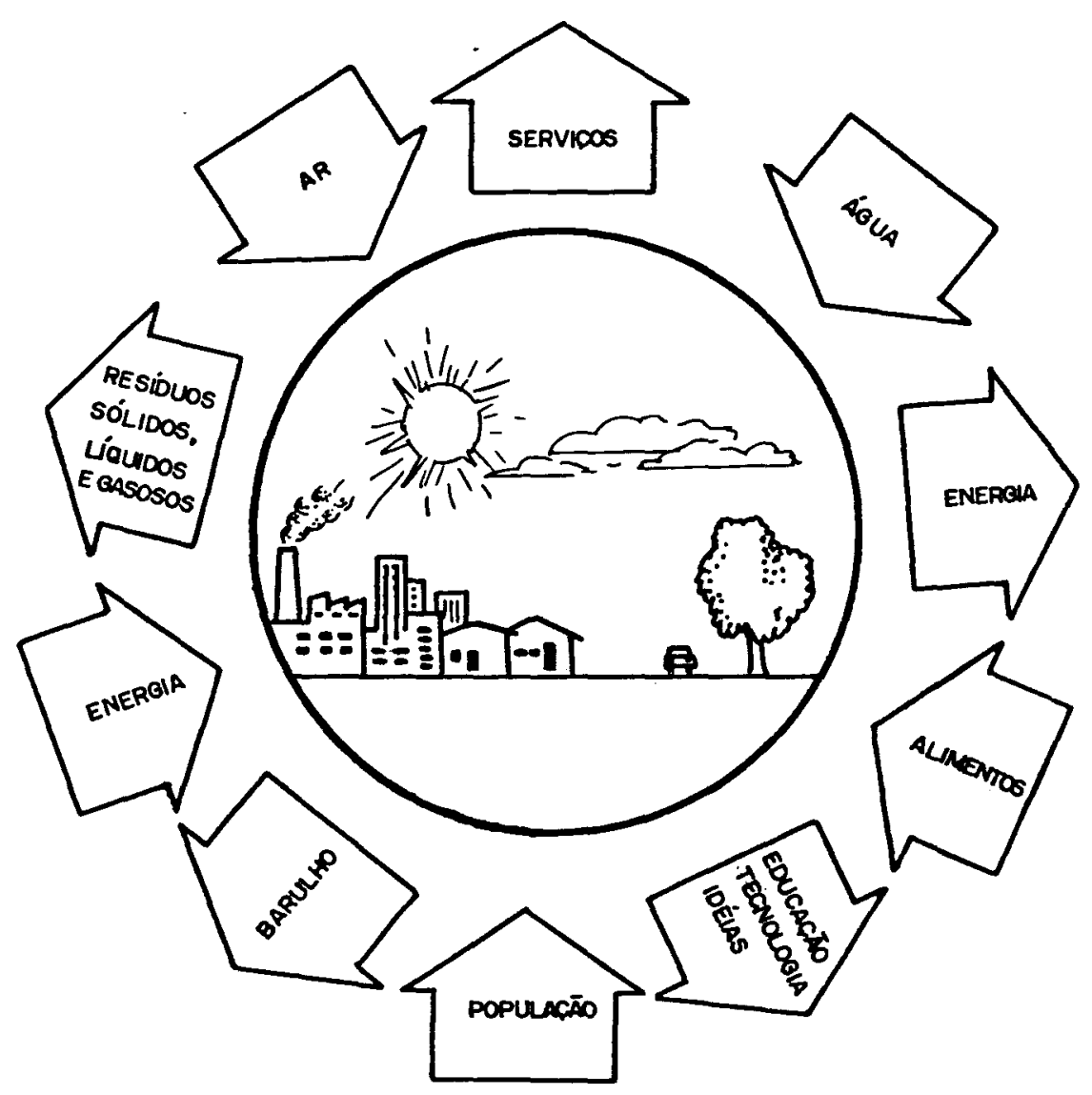

FIBURA 4.1

- ECOSBISTEMA URBANO - RECURSOS E PRODUTOS 
recéndö à sua ocupação.

com o desenvolvimento tecnologico atual, multos obs täculos naturais podem ser vencidos pelo homem. Porém, is to pọ de ocofrer a úm custo económico muito alto, ou mesmo com altera çöes ecológlcas de grande porte.

Compete ao homem a ocupaçāo ordenada do solo, com a utilizaçăo racional do ambiente físico, de forma a garantir um ecossistema urbano equilibrado, que lhe oferega as melhores con diçōes de vidai

4:2 - Cafacterísticas ambientais e a urbanizaçăo

0 meto ambiente pode exercer infiuenclas sobre o pro cesso de urbahizaçă, atravĕs de caractetisticas que lhe são fa voräveis ou não.

o processo de urbanizaçāo, por outro lado, provoca modificaçōes no meio ambiente, alterando suas características.

As condiçōes climäticas de uma região, a sua topogra fia, tipos e formaçōes de solos, os recursos hidricos e a cober tura vegetal, entre outros, são características de um ambiente que estāo relacionadas com a urbanização, influindo no proces so ou sendo modificadas por ele.

Algumas características do meio podem ser usadas co mo elementos que orientarão a definição dos diversos usos do so 10. Por outro lado, o conhecimento dos impactos ambientais das diversas atividades em um meio urbano é importante no discipli namento do uso do solo.

A seguir, säo discutidos os principais fatores ambi entais relacionados com a urbanização. Posteriormente, serä es tudado como os mesmos podem ser utilizados ro disciplinamento do uso do solo urbano.

Conforme veremos no desenrolar do trabalho, estas ca racterísticas estāo interrelacionadas, influindo umas sobre as outras. Apenas para efeito didätico serão estudadas separadamen te. 


\section{$4: 2 i i$ - Condiçōes climăticas}

Entre os fatores climäticos que estão relacionados com a urbanizaçāo, podemos citar:

- Radiação solar

- Temperatura

- Velocidade e direção dos ventos

- Precipitação

- Umidade

- Camadas atmosfëricas

Em algumas regiōes, a distribuiçāo da cidade e os tí pos de construção devem favorecer à incidência do sol. Em ou tras, onde a radiação solar ē intensa, esta incidência deve ser diminuída ou evitada.

A temperatura estā relacionada com a urbanizaçāo. A reas pavimentadas absorvem mais calor durante o dia e expelem durante a noite, aumentando a temperatura. Além disto, com a pa vimentação hà um escoamento mais rảpido da ägua e, em consequén cia, um secamento mais rāpido do solo, diminuindo o processo de evaporação, o qual tem efeito de resfriamento da superfície da Terra. Hä ainda a considerar as atividades normais do meio urba no (mäquinas e veículos) que produzem calor e contribuem para o aumento da temperatura.

A velocidade dos ventos é menor nas cidades, em con sequência de barreiras (edificações) que são criadas a sua cír culação.

Nas cidades, observa-se maior precipitação pluvial do que nos campos, pois as atividades humanas neste meio produ zem maior nümero de nücleos de condensaçāo. Por outro lado,con tata-se menor umidade relativa nas áreas urbanas do que nos cam pos.

As camadas atmosfēricas, com suas possiveis inver sōes, são fatores importantes que estão diretamente relaciona dos com a dispersāo dos poluentes atmosféricos resultantes de atividades urbanas. A direçāo e a velocidade dos ventos são ou tros fatores a considerar sob este aspecto.

o desmatamento provoca alteraçōes climäticas, pois a vegetaçāo é responsāvel pela regularizaçăo da temperatura e da umidade. Além disto, a arborização contribui para uma melhor ventil açāo. 
Nos QUADROS 4.1 e 4.2 indicamos como a urbanizaçäo pode modificar as condiçōes climäticas. O QUADRO 4.1 mostra as alteraçōes climáticas causadas pela urbanização, comparando com - meio rural. O QUADRO 4.2 apresenta variaçoes de temperatura em diversas äreas de Washington, D.C. (Estados Unidos) e de Sheffield (Inglaterra), em função de diversos usos do solo ur bano.

Vemos que as alterações climăticas resultarites do processo de urbanização são significativas. Todos estes aspec tos devem ser considerados no planejamento urbano, pois a corre ta utilização destas características conduzirä a um ambiente u bano com melhores condiçōes de vida.

A urbanização, de qualquer modo, provocarä mudanças ambientais, jä que a transformação de atividade rural para urta na é feita com alteraçōes no meio. Compete aos planejadores dis ciplinar este processo, de forma que as repercussões sejam as mínimas possíveis. 
QUADRO 4.1

Mudanças Mẻdias em Características Climáticas, causadas pela Urbanizaçāo

C A R A C T E R T S T I C A S

COMPARAÇÃO COM 0

MEIO RURAL

Radiaçāo

global

ultravioleta (no inverno)

15 a $20 \%$ menor

ultravioleta (no verāo)

$30 \%$ menor

$5 \%$ menor

duração de exposição ao sol

5 a $15 \%$ menor

Temperatura

média anual

médias das mínimas no inverno

0,5 a $1,0^{\circ} \mathrm{C}$ maior

1 a $2{ }^{\circ} \mathrm{C}$ maior

Contaminantes

nücleos e partículas de condensaçāo

10 vezes maior

misturas gasosas

5 a 25 vezes maior

Velocidade do vento

mëdia anual

20 a $30 \%$ menor

rajadas extremas

10 a $20 \%$ menor

calmarias

5 a $20 \%$ maior

Precipitação

total

dias com menos de $5 \mathrm{~mm}$

neve

Nebulosidade

cobertura

nevoeiro (no inverno)

nevoeiro (no veräo)

Umidade relativa

no inverno

no veräo
$2 \%$ menor

5 a $10 \%$ maior

$10 \%$ maior

$5 \%$ menor

5 a $10 \%$ maior

$100 \%$ maior

$30 \%$ maior

$8 \%$ menor

FONTE: LANDSBERG, H.E. 1970 (28) 


$$
\text { QUADRO } 4.2
$$

Variaçoes de temperatura com o uso do solo urbano,em thashington, D.C. e Sheffield (iñglaterra), em um dia claro de verão

\begin{tabular}{|c|c|c|c|c|}
\hline \multirow{2}{*}{ USO DO SOLO } & \multicolumn{2}{|c|}{ WASHINGTON, D.C: } & \multicolumn{2}{|c|}{ SHEFFIELD } \\
\hline & $\begin{array}{c}\text { Durante } \\
\text { o dia }\end{array}$ & $\grave{a}$ noite & $\begin{array}{c}\text { Durante } \\
\text { odia dia }\end{array}$ & à noite \\
\hline Centro Comercial & $97^{\circ} \mathrm{F}$ & $35^{\circ} \mathrm{F}$ & $69^{\circ} \mathrm{F}$ & $54^{\circ} \mathrm{F}$ \\
\hline Industrial & - & - & 71 & 56 \\
\hline Residencial denso & 96 & 83 & 70 & 53 \\
\hline \multicolumn{5}{|l|}{ Parque,pröximo ao } \\
\hline centro da cidade & 95 & 84 & 66 & 46 \\
\hline \multicolumn{5}{|l|}{ Parque,prōximo aos } \\
\hline limites da cidade & 94 & 78 & - & - \\
\hline Residencial suburbano & 95 & 79 & 69 & 51 \\
\hline Heio rural & 95 & 76 & 65 & 43 \\
\hline \multicolumn{5}{|l|}{ Variaçōes māximas } \\
\hline observadas & 3 & 9 & 6 & 14 \\
\hline
\end{tabular}

FONTE: LANDSBERG, H.E. 1968 (29) 
4.2 .2 - Topografia

A topografia de uma ảrea pode influir no processo de urbanizaçāo. Por exemplo, terrenos com grandes declividades po dem ser considerados nāo apropriados para ocupaçāo urbana, devi do aos problemas de instabilidade.

Algumas vezes. O homem consegue vencer obstäculos re lacionados com a topografia nāo favorável, mas isto è feito com movimentação de terra e outras açōes sobre a latureza impactós adversos à palsagem ou prejuízos à qualidade do meio ambientel

A declividade do terreno contribui para o escoamento das äguas. Quanto malor for o trecho em declive, malor serä o escoamento da ägua pela superfície, carreando solo (atravēśda erosão) e outros materiais para os recursos hídricos superficl ais, influindo, portanto, na qualidade da ägua dos mesmos. (Ver QUADRO 4.3 )

QUADRO 4.3

Erosāo do Solo em funçāo da Topografia

\begin{tabular}{ll}
\hline \multicolumn{1}{c}{ Topografia } & $\begin{array}{l}\text { Quantidade de Sedimentos } \\
\text { produzidos (em tonelada } \\
\text { por milha quadrada p/ano) }\end{array}$ \\
\hline Area de florestas (plana) & 10 a 40 \\
Area de florestas (em declive) & 25 a 100 \\
Area urbana (plana) & 25 a 100 \\
Area urbana (em declive) & 75 a 500 \\
\hline
\end{tabular}

FONTE: U.S. FOREST SERVICE. 1969 (59)

Obs. I milha quadrada $=2,59$ quilómetros quadrados

As condiçōes topogräficas estão, tambēm, relacionadas com as características climäticas. Por exemplo, a ocorréncia de inversōes de temperatura, que podem contribuir para o agravamen to da poluiçāo do ar, é comum em vales. 0 posicionamento topo gräfico de determinada àrea pode influir para uma maior ou me nor incidencia do sol sobre a mesma. 
Areas baixas estāo mais sujeitas a Inundaçōes do que terrenos elevados, most trando que ha, tambèm, um interrelaciona mento entre a topografia e fatores hidrologicos.

\section{2 .3 - Geologia}

As condiçōes geolögicas de uma ärea urbana têm gran de influéncia sobre o seu processo de expansäo.

Cada tipo de solo tem características pröprias, as quais podem influir decisivamente no tipo de ocupaçāo de deter minada zoña urbana.

Assim, fatores geolögicos podem ser favoräveis ou a presentar limitaçöes a determlnado uso do soloi

Algumas formaçōes geológicas apresehtam caräcterfist 1 cas que interessam à construção civil: resistência a cargas, umi dade, plasticidade, permeabilidade, capacidade de absorçăo,etc. Por outro lado, constituindo-se material de värias modalidades da construçāo civil, é claro que o solo tem papel importante no processo de urbanizaçäo.

Alguns tipos de solo na cldade sāo recomendados para implantaçāo de āreas verdes, campos de golfe, äreas de lazer ou usos similares.

Os aspectos geolögicos estäo intimamente relaciona dos com fatores hidrológicos, no que se refere, por exemplo, a: nível de lençol freātico, infiltraçāo da ägua precipitada, ero sāo, āreas alagadas, recarga do lençol freātico, entre outros.

A àgua que se infiltra no terreno, além de outros fatores, depende, tambēm, do tipo de solo sobre o qual incide. A Infiltração ë maior em solos arenosos, mais permeáveis, do que em solos argilosos, por exemplo.

Com relaçāo à erosāo, è claro que a quantidade de partículas de solo transportada pela àgua depende do gráu de de sagregação da rocha constituinte do terreno. Geralmente, solos argllosos sāo susceptílveis a erosāo, devido serem compostos de finos grãos, os quais sāo facilmente dissolvidos na ägua.

Além da estrutura do solo, outros fatores estäo rela cionados com o processo de erosäo:

- Intensidade e duração das chuvas

- Tlpo de uso do solo 
- Cobertura vegetal do solo

- Topografia: declividade (grau e comprimento do de clive)

Os QUADROS 4.3 e 4.4 , apresentam dados do Serviço de Florestas dos Estados Unidos da Amérlca/ relacionando a quanti dades de sedimentos carreados pelo processo de erosão com o t po de uso do solo e a topografia.

O QUADRO 4.5 mostra outros valores coletados nos ES tados Unidos, para sedimentos produzidos em diferentes usos do solo. Podemos observar uma grande quantidade de sedimentos em á reas ainda em processo de desenvolvimento, onde o rítmo de con truçōes é intenso.

Outra característica dos solos relacionada com o pro cesso de urbanizaçäo, $\vec{e}$ a sua capacidade de utillząăo como meio de absorção de líquidos provenientes de fossas. Em āreas desprovidas de redes de esgoto sanitärio, este aspecto - è de grande importäncia, quando da definição dos diversos usos do so lo urbano.

0 conhecimento das características do solo é indis pensävel, tambēm, na escolha de āreas para aterros sanitärios, bem como para sistemas de disposição de residuos líquidos e de lodos em terrenos. 


\section{QUADRO 4.4}

Erosāo em função do Uso do Solo

\begin{tabular}{lr} 
USO DO SOLO & $\begin{array}{l}\text { QUANTIDADE DE SEDIMENTOS PRO } \\
\text { DUZIDOS (em tonelada Por mI } \\
\text { lha quadrada por ano) }\end{array}$ \\
\hline $\begin{array}{l}\text { Florestas } \\
\text { Uso agricola }\end{array}$ & $\begin{array}{c}9 \text { a } 50 \\
\text { Construçóes suburbanas } \\
\text { Residencial (após estabilizaçăo) }\end{array} \quad 25.000$ a 50.000 \\
\hline
\end{tabular}

FONTE: U.S. FOREST SERVICE. 1969 (59)

obs. I milha quadrada $=2,59$ quilómetros quadrados

$$
\text { QUADRO } 4.5
$$

Volume de Sedimentos erodidos, por tipo de Uso do Solo

\begin{tabular}{lcc}
\hline USO DO SOLO & $\begin{array}{c}\text { VOLUME DE SEDIMENTOS ERODIDos } \\
\text { (Em tonelada por milha quadra } \\
\text { da por ano) }\end{array}$ \\
\hline Áreas com vegetação & 100 \\
Áreas rurais de uso misto & 300 \\
Áreas agrícolas (fazendas) & 500 \\
Áreas em desenvolvimento leve & 10,000 \\
Areas em desenvolvimento intenso & 100.000 \\
\hline
\end{tabular}

FONTE: LEOPOLD, L.B. 1968 (30) 
4.2.4 - Fatores hidrológicos

A ägua, como elemento indispensāvel à vida humana, tem sido fator importante na localização e desenvolvimento de cidades.

Alēm do atendimento às necessidades biolögicas do ho mem, a água cada dia se torna mais necessäria para outros usos, tais como: suprimento a indústrias, produção de energia, irriga ção, recreação, pesca, etc.

Assim, é importante, sob o aspecto da ocupação do so lo para fins urbanos, que a ägua seja garantida em quantidade e qualidade necessärias aos usos para os quais se destinam.

Toda a ägua que dispomos faz parte do Ciclo Hidroló gico, no qual este líquido circula através do ar, da superfície do solo e do sub-solo, compreendendo os processos de: Precipita ção, Infiltração, Escoamento Superficial ("runoff"), Escoamento Subterrâneo, Evaporação e Evapo-Transpiração.

o processo de urbanização pode provocar alteraçōes sensíveis no Ciclo Hidrolögico, principalmente sob os seguintes aspectos: (Ver FIGURA 4.2)

- Aumento da precipitação, conforme jä comentado an teriormente (ítem 4.2.1)

- Diminuição da evapo-transpiração, como consequên cia da redução da vegetação

- Aumento da quantidade de líquido escoado (aumento do "runoff")

- Diminuição da infiltração da ägua, devido a imper meabilização e compactação do solo. Os gräficos da FIGURA 4.3 mostram as porcentagens de ägua infil trada, escoada e evapotranspirada, em função da pa vimentação da superfície do solo

- Consumo de àgua superficial e subterrânea, para a bastecimento público, usos industriais e outros

- Mudanças co nível do lençol freático, podendo ocor rer redução ou esgotamento do mesmo

- Maior erosão do solo e consequente aumento do pro cesso de assoreamento das coleçöes superficials de àgua 


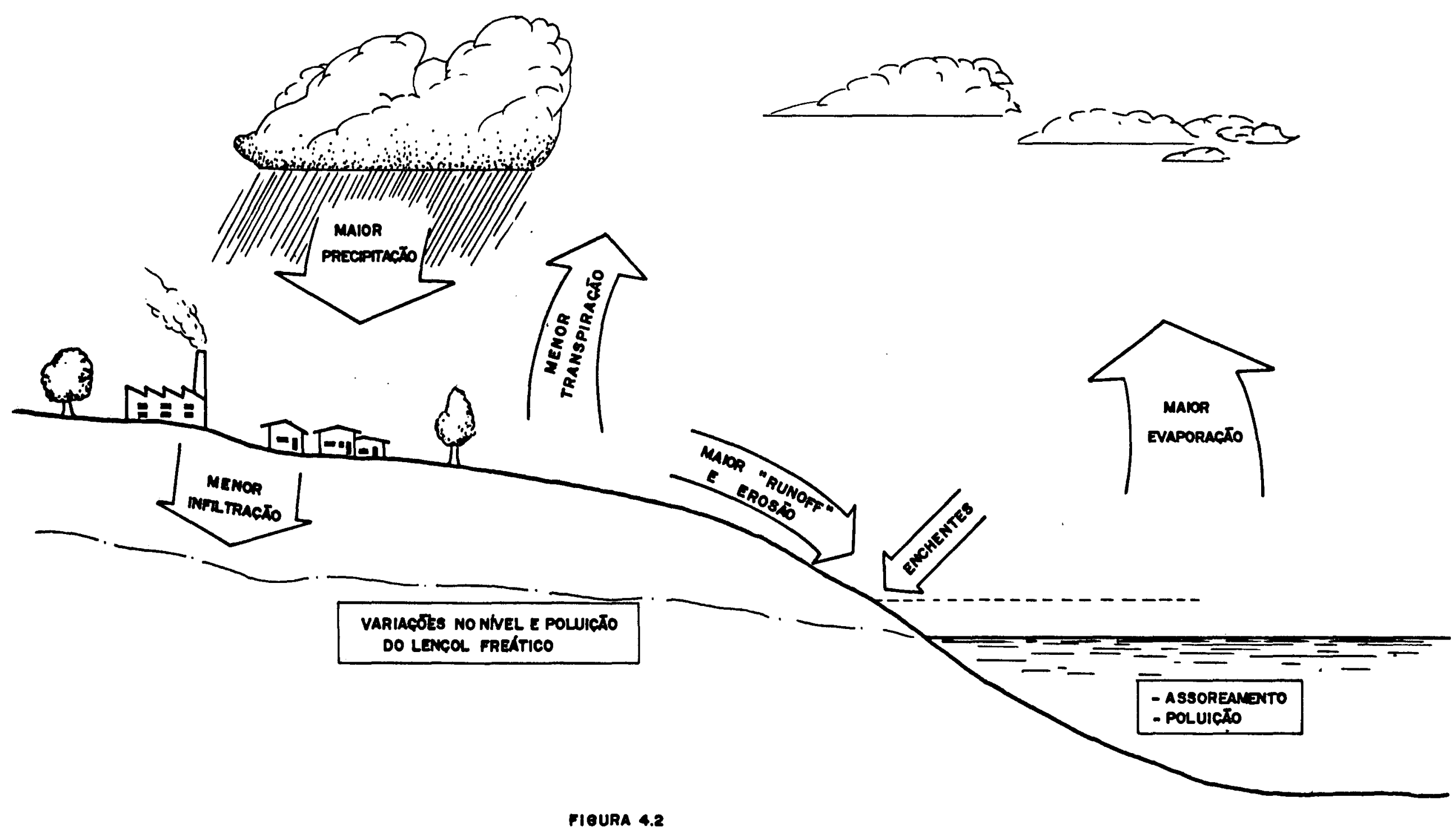

CONSEQUENCIAS DA URBANIZAGÃO SOBRE O CICLO HIDROLOEOICO 


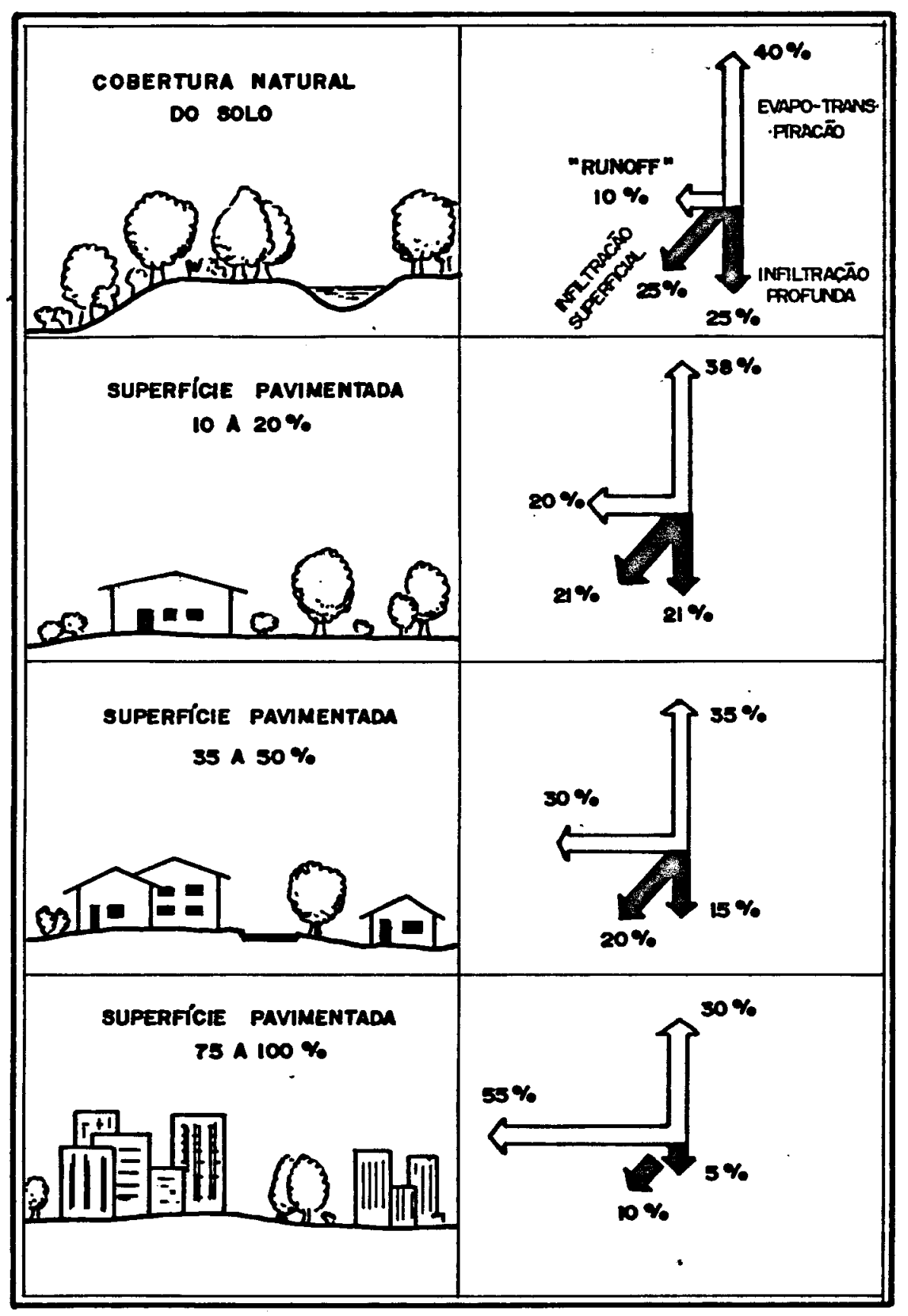

FIOURA 4.3

INFILTRACÃo. "RUNOFF" E EVAPO-TRANSPIRACÃo. EM FUNCX̃o da PAVIMENTAC̄̃o dA SUPERFICIE dO SOLO 
- Aumento da ocorréncia de enchentes

- Poluiçāo de àguas superficiais e subterrâneas.

Tódas estas alteraçōes no Ciclo Hidrológico podem re sultar em condicōes bastante prejudiciais para os habitantes de uma àrea urbana. Portanto, estes aspectos devem ser considera dos na ocupaçăo do solo, visando minimizar os seus efeitos ne gativos.

4.2 .5 - Outras características ambientais

Alèm dos fatores já comentados, outras característi cas ambientais estäo relacionadas com o processo de urbaniza çăo.

A ocupaçāo de äreas primitivamente rurais por usos predominantemente urbanos, pode processar-se em detrimento de características especiais do meio amiente, tais como:

- Vegetaçāo

- Areas de valor histōrico ou paisagistico

- Areas de importância ecológica

Nos comentärios feitos nos itens anteriores, jä res saltamos a importância da vegetaçăo e mostramos que a sua des truiçāo resulta em mudanças indesejäveis no meio ambiente.

A cobertura vegetal do solo está relacionada com os seguintes aspectos ambientais:

- Contribui para a retenção e a estabilizaçăo dos so los

- Previne contra a erosāo do solo, pois tem efeito a mortecedor da chuva e favorace à infiltração da á gua, proporcionando menor escoamento superficial.

- Integra o Ciclo Hidrolögico, atravês do processo de transpiraçảo

- As margens de cursos d'ägua, produz sombra que man tẻ́m a àgua na temperatura adequada às diversas es pëcies de peixes e de outros organismos aquäticos

- Influi no clima, pois interfere na incidencia do sol, velocidade dos ventos e precipitação de āguas pluviais 
- Atravēs da fotosíntese, fornece oxigênlo ao meio

- E fonte de alimentos e matéria prima

- Está intimamente relacionada com a paisagem, ofe recendo aspecto visual agradä́vel

- Constitui amblente natural para diversas espécies animal

- Pode ser considerada como um meio dispersor e absorvente de poluentes atmosférios, ou como barrel ra à propagação de ruídos.

Obviamente, a ocupação urbana resultarā sempre numa diminuigăo da cobertura vegetal original do solo. No entanto,se as principais características ambientais forem consideradas, a travës de uma utilização ordenada do solo, os efeitos sobre o melo ambiente serão minimizados e as consequências benēficas da vegetação poderão ser aproveitadas em favor da populaçāo.

0 mesmo ocorre com as àreas de valor histörico, eco lögico ou paisagístico, as quais devem ser usadas como alemen tos disciplinadores do uso do solo urbano.

4.3 - Urbanização e poluição do meio ambiente

Uma das consequências do processo de urbanizaçāo è a poluição do meio ambienté.

A poluição ambiental pode ser definida como qualquer alteraçāo das características de um ambiente (ägua, ar ou solo) de modo a tornā-lo imprōprio às formas de vida que ele norma 1 mente abriga. Estas modificaçōes podem ser resultantes da pré sença, lançamento ou liberação, no ambiente, de matëria ou ener gia, em quantidade ou intensidade tais que o tornem impröprio.

o processo de urbanização resulta em modificaçōes so bre o meio ambiente, como consequência de:

- Alteracões no ambiente terrestre, necessārias à im plantaçäo da cidade. Exemplos: movimentos de terra; desmatamen tos; desvios de cursos d'ägua.

- Utilizaçāo dos recursos naturais, como fonte de ma tèria e energia necessärias às atividades humanas. Exemplos:cap tação de ägua para abastecimento püblico e outros usos; queima de materiais para produção de energia; obtenção de matērla prí ma para processos industriais. 
- Lançamento, no ambiente, de resíduos resultantes de processos biológicos do homem ou de atividades que ele desen volve na cidade. Exemplos: gases expelidos por veículos automo tores ou provenientes de processos industriais; esgotos domésti cos e resíduos líquidos industriais; resíduos sölidos de diver sas procedências.

Todas estas atividades humanas no meio urbano, se nāo realizadas ordenadamente, podem ocasionar alteraçöes drásticas no ambiente, ou seja; podem causár a poluiçăo. Comio elemento do ecossistema urbano, o homen podé ser afetado pela polulçāo, a qual pode caúsar-lhe prejuizos à saúde; provocár danos aos seus bens e prejudtcar as suas atividades hormaisi (FIGURA 4.4)

Podemos classificar as diversas formas de poluicão ambiental nos seguintes tipos principais:

- Poluição do solo

- Poluição do ar

- Poluição da ägua

- Poluição acústica

- Poluição visual

Na realidade, nem sempre podemos separar a poluifăo ambiental por modalidades, pois, muitas vezes, elas ocorrem con juntamente, havendo muitos fatores de interdependencia entre as mesmas. Por exemplo, o lançamento do lixo em terrenos baldios resulta na poluição do solo e pode ocasionar a poluição da á gua superficial ou subterrânea, atravēs do escoamento ou infi! traçāo da ăgua de chuva percolada atravēs dos resíduos. Por ou tro lado, é comum a queima do lixo exposto, resultando na polui ção do ar. A poluicão visual - aspecto estētico desagradāvel $\vec{e}$ outra consequência dos depōsitos de lixo a cẻu aberto.

Assim, nem sempre è possível estudar-se isoladamente uma determinada modalidade de poluição. Apenas por facilidade didätica è que isto é feito.

Na adoção de medidas de controle da poluição é neces sārio conhecer como a mesma ocorre, suas fontes e processos. Í to ë multo importante, principalmente na implantação de medidas preventivas de controle.

o disciplinamento do uso do solo, como já dissemos, pode ser feito visando a preservação do meio ambiente e, portan to, como uma medida preventiva contra a poluiçāo. Para isto, $\overline{\bar{e}}$ 


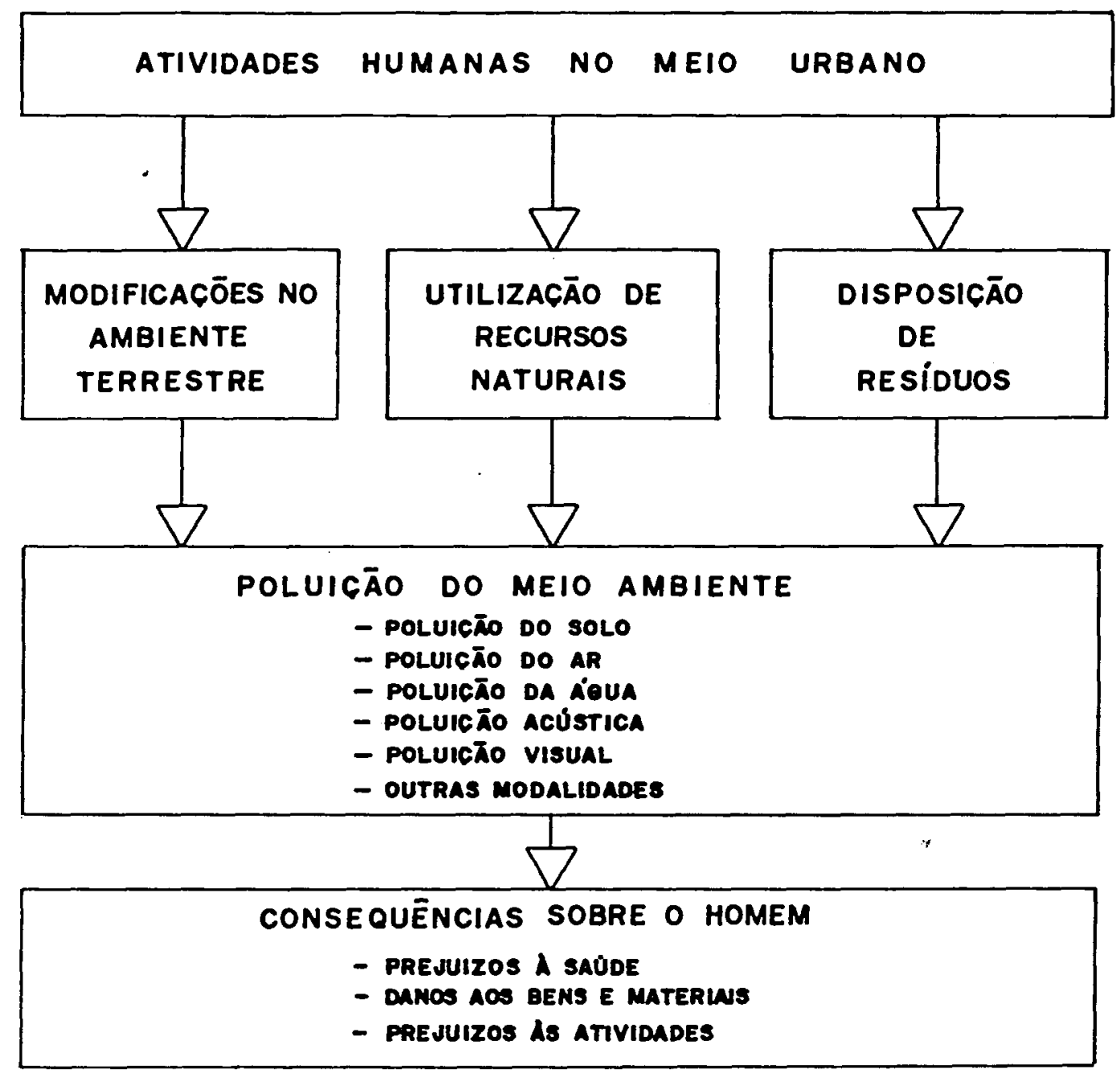

FIOURA 4.4

ATIVIDADES HUMANAS NO MEIO URBANO

E A POLUICATO AMBIENTAL 
necessārio que se conheçam os mecanismos de ocorrência das di versas modalidades de poluiçäo e os princípios de saneamento pá ra evitá-las, com ofim de aplicā-los ao planejamento territori al.

o corihecímento de como pode acontecer a poluição do ar, da ăgua, do. solo; acüstica e visual, em um meio urbano, bém como dos prlncípios santa ários que podem ser aplicados no discl plinamento do uso do solo para evitar a sua ocorrência, conduzi rá a um bom planejamento territorial, o qual definirä uma ocupa çäo de acordo com as características naturais do ambiente, com modificaçōes adversas mínimas possíveis.

A seguir, estudaremos as diversas modalidades de po luição. Posteriormente, discuti remos como o conhecimento dos me canismos de sua ocorrência e de sua prevenção pode ser aplica do ao planejamento urbano.

4.3 .1 - Poluição do solo

As atividades que o homem desenvolve sobre o solo. alterando as suas características naturais, seja através de mu danças na sua estrutura física, seja pelo lançamento de resídu os em sua superfície, podem resultar na sua poluição.

No meio uriano, muitas sāo as modificaçōes impostas ao solo e as mesmas, resultarido em uma forma de poluição - a poluição do solo, podem ser prejudiciais aos or ganismos que vivem nesta parte do ambiente natural, com refle xos sobre o homem.

As principais fontes de poluiçäo do solo säo:

- Aplicação de agentes químicos

- Presença de dejetos oriundos de animais

- Despejos de resíduos sōlidos

- Lançamentos de resíduos líquidos, domésticos ou ín dustriais

- Atividades que possam resultar na erosão do solo

Os agentes químicos aplicados no solo podem ser de duas modalidades: (a) defensivos agrícolas, que em um meio urba no săo usados, geralmente, para combate a hervas daninhas de ví as públicas, para eliminação de insetos e roedores nocivos, ou 
mesmo visando o extermínio de pragas de pequenas lavouras;

fertilizantes aplicados em äreas paisagisticas públlcas,jardins particulares ou pequenas culturas.

A poluição do solo por defensivos agricolas êj prin cipalmente, devida aos inseticidas clorados orgänicos, os quals têm alta persistência no solo, podendo levar värios anos para desaparecerem, após a sua aplicação. O QUADRO $4: 6$, mostra a I guns dados sobre a persistência de determinados inseticidas no solo; podendo-se observar que são necessärios até mais de uma dezena de anos para o desaparecimehto de alguns deles

QUADRO 4.6

Persistēncia de alguns Inseticldas clorados no solo

INSETICIDA

QUANTIDADE TEMPO DE DESAPARECIMENTO DE $95 \%$ APL I CADA

$(\mathrm{Kg} /$ hectare)

I NTERVALOS

VALORES MEDIOS

$\begin{array}{llll}\text { Aldrin } & 1-3 & 1-6 \text { anos } & 3 \text { anos } \\ \text { Clordana } & 1-2 & 3-5 \text { anos } & 4 \text { anos } \\ \text { DDE } & 1-2,5 & 4-30 \text { anos } & 10 \text { anos } \\ \text { Dieldrin } & 1-3 & 5-25 \text { anos } & 8 \text { anos } \\ \text { Heptacloro } & 1-3 & 3-5 \text { anos } & 3,5 \text { anos } \\ \text { Lindana } & 1-2,5 & 3-10 \text { anos } & 6,5 \text { anos } \\ \text { Telodrin } & 1 / 4-1 & 2-7 \text { anos } & 4 \text { anos }\end{array}$

FONTE: C.A. EDWARDS - Residue Rev. n: 83. 1966

No entanto, existem defensivos agrícolas com pouca persistência no solo, tais como os fosforados orgānicos, os quals, quando preciso, podem ser aplicados sem maiores proble mas, desde que todos os cuidados necessärios sejam adotados.

os fertilizantes sāo aplicados ao solo visando melho rar a sua produtividade agrícola. No entanto, normalmente eles adicionam nutrientes ao terreno - nitrogēnio, fösforo e potás sio, os quais podem ser indesejáveis. Um dos exemplos da indese jabilidade destes nutrientes é o problema da eutrofizaçăo da gua, como consequência da presença, em excesso, dos mesmos, os 
quais foram carreados atavés de líquidos escoados ou percolados no solo.

No meio urbano, ao conträrio de áreas rurais, a pre sença de dejetos de animais no solo não é considerävel. No en tanto, a criação de animais domēsticos ou mesmo a presança de pequenos estäbulos, pocilgas e granjas, podem resultar na polui ção do solo por excrementos de animais.

os detritos dos animais podem conter micro-organis mos patogênicos e podem contribuir para a poluição da ăgua que entra ém contato com os mesmos, atravēs do solo, alterando sua qualidade, inclusive contribuindo para uma elevada Demanda Bio química de oxigēnio - DBO. Jä existem estudos comparativos en tre a produção de $D B O$ a partir de fezes de alguns animais e a quantidade produzida pela matéria fecal humana, conforme indi cado no QUADRO 4.7 .

$$
\text { QUADRO } 4.7
$$

População Equivalente de produção fecal de animais, em termos de Demanda Bioquínica de $0 \times$ igènio

\begin{tabular}{lc}
\hline ORIGEM DOS DEJETOS & EQUIVALENTE POPULACIONAL \\
\hline Homem & 1,0 \\
Cavalo & 11,3 \\
Vaca & 16,4 \\
Carnel ro & 2,45 \\
Porco & 1,9 \\
Galinha & 0,14 \\
\hline
\end{tabular}

FONTE: PARKER, H.W. 1975 (42)

os resíduos sōlidos das cidades têm, muitas vezes, co mo destino final a sua disposição sobre o solo, seja em simples aterro a céu aberto, seja atravès do processo conhecido como "aterro sanitärio".

Quando o lixo é despejado em aterros a cēu aberto, a poluição do solo pode resultar em: 
- Aspecto estētico desagradāvel

- Maus odores, resultantes da decomposiçäo dos detrl tos

- Proliferação de insetos e roedores, transmissores de doenças

- Possibilidade de acesso de pessoas, podendo ocasio nar doenças por contato direto

- Poluição da ãgua subterrānea ou superficial, atra vés da infiltração de líquidos e carreamento de im purezas por escoamento superficial

- Possibilidade de queima dos resíduos, com incómo dos à população e causando a poluição do ar

- Desvalorização de áreas pröximas ao depösito dos resíduos sōlidos

Mesmo a solução conhecida como "aterro sanitārio", quando não corretamente aplicada, pode causar a poluição do so lo e, a partir daí, provocar a poluição de àguas superficiais ou subterrâneas nas proximidades, conforme discutiremos proxima mente.

A disposição, no solo, de lodos resultantes de pro cessos de tratamento de esgoto é outra fonte de poluição. E co mum a presença. nestes lodos, de ovos de parasitas intestinais, de micro-organismos patogênicos resistentes ao tratamento e de compostos químicos nocivos.

0 destino a ser dado aos resíduos sölidos contendo substāncias töxicas, resultantes de processos industriais, vem se constituindo um problema de difícil solução, pois o seu lan çamento no solo pode resultar na poluição do mesmo, com graves consequências para o homem.

os resíduos líquidos, domésticos ou industriais, são lançados no solo, em duas condiçöes:

(1) Devido à falta de um sistema adequado de esgcta mento sanitärio, favorecendo à prätica não corre ta de dispor os dejetos humanos ou resíduos in dustriais diretamente sobre a solo.

(2) Em processo de tratamento de esgoto, quando o II quido é disposto em lagoas de estabilizaçāo, ou utilização em prāticas de irrigação agrícola. 
Os esgotos domésticos lançados no solo favorecem ao contato direto das pessoas com organismos patogénicos, sendo co mum a transmissão de doenças originärias de ovos de parasitas intestinais, tais como a ancilostomíase e as helmintoses.

Estes líquidos, infiltrando-se no terreno, podem cay sar poluição da ăgua subterrânea e superficial, o mesmo aconte cendo com os que são percolados a partir de lagoas de estabili zação ou de präticas de irrigação.

A erosão, sendo um processo de modificação da estrü tura do solo, pode ser entendida como uma forma de poluição.

A erosão causa sērios prejuízos à produtividade më dia do terra, pois provoca desequilíbrios hidro-geológicos, pro duzindo variações drásticas na composição e estrutura da fauna. Por outro lado, constitui um mecanismo de poluiçāo da ägua,pois - carreamento de pequenas partículas de solo, no processo de erosão provoca alterações na qualidade da ägua, resultando em desequilibrios ecolögicos.

Em itens anteriores, comentamos alguns aspectos rela cionados com a erosão do solo, mostrando a relação entre o uso do solo e este processo.

Conforme podemos observar nos comentārios feitos atë aqui, a poluição do solo está muito relacionada com a poluição da ägua, podendo-se dizer que a primeira é uma das fontes de corréncia da segurida.

4.3 .2 - Poluição da àgua

A utilização que o homem faz da àgua para consumo pessoal, para uso doméstico ou para outras atividades, resulta em residuos liquidos, os quais voltam novamente aos recursos hí dricos, causando a sua poluição.

Por outro lado, a água que precipita carreia impure zas do ar e do solo para as coleçós superficiais ou subterrāne as de água, alterando a sua qualidade, ou seja, poluindo-a.

Assim, värios são os mecanismos de poluição da ãgua superficial e subterrânea em um meio urbano, podendo-se desta car como principais fontes de poluição: (FIGURA 4.5) 


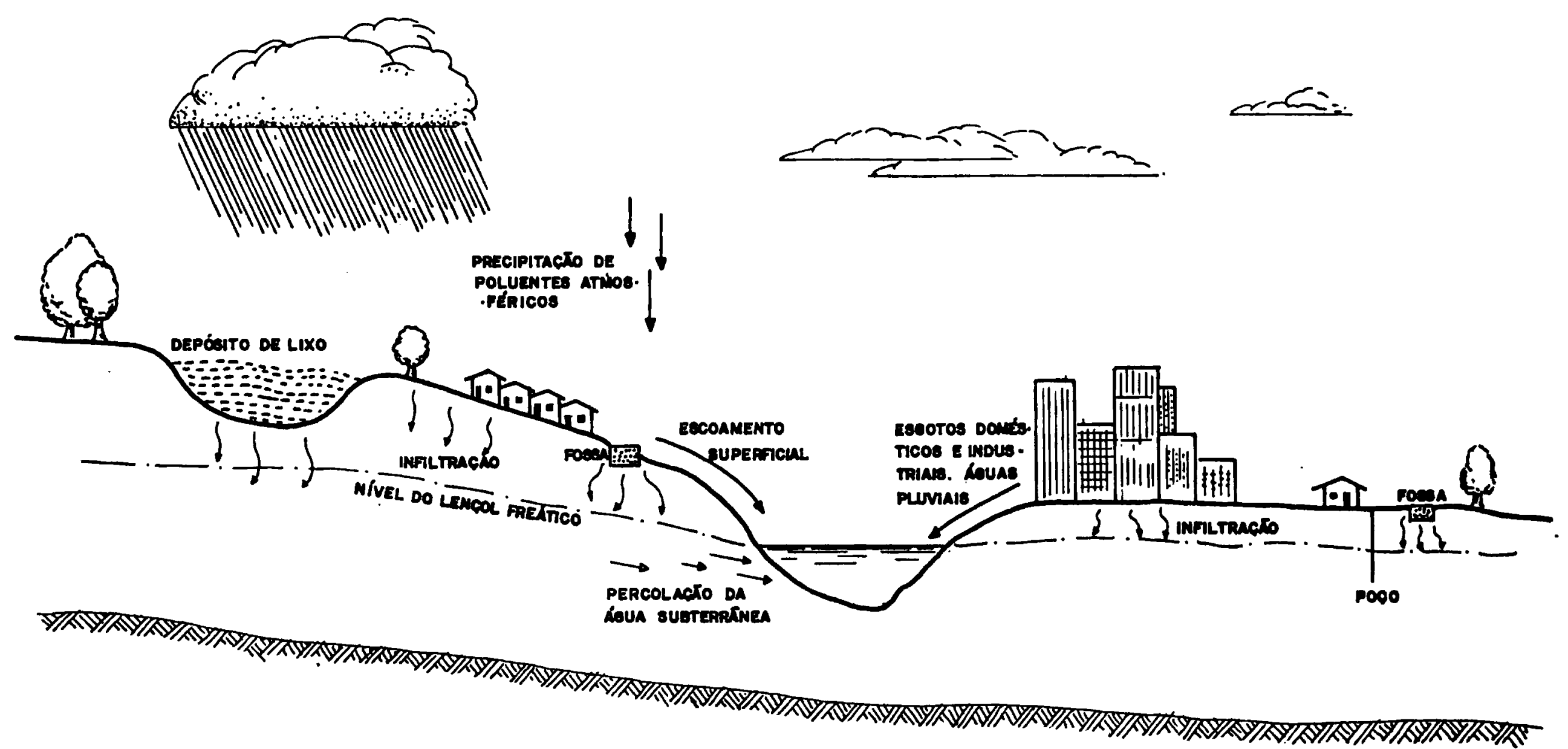

piouaA 4.0

PRINCIPAIS MODOS DE OCORRẼNGIA DA POLUICT̃O DA LOUAA 
(a) Fontes localizadas de poluição da ägua

- Lançamento de esgotos domésticos (sanitärios)

- Lançamento de esgotos industriais

- Lançamento de āgua pluviais, atravēs de galerí as

(b) Fontes não localizadas de poluição da āgua

- Agua de escoamento superficlal ("runoff")

- Água de infiltração

- Lançamento direto de resíduos sólidos e outras i mpurezas

- Intrusão de ägua salgada

Todos estes processos alteram a qualidade da água,po dendo tornäla imprópria ao homem ou a outras formas de vida, conforme mostrado na figura 4.6 .

4.3.2.1 - Fontes localizadas de poluiçäo da āgua

os esgotos domésticos ou sanitários compreendem os resíduos líquldos provenientes de instalaçōes sanitārias, lava gem de utensílios domésticos, lavagem de roupas, ou outras ati vidades desenvolvidas nas habitaçōes, prédios comercials, prēdi os püblicos, etc.

Os esgotos domésticos caracterizam-se "pela grande quantidade de matēria orgānica que contêm, o que causa redução do oxigēnio dissolvido na āgua que os recebe, como resultado de sua estabilização pelas bactērias.

Como os resíduos dos processos biológicos do homem estäo contidos nos esgotos domésticos, normalmente os mesmos possuem bactērias e organismos patogênicos.

Assim, o lançamento de esgotos domésticos na ägua po de causar doenças às pessoas que ingerem este líquido, ou o ut lizam em atividades recreacionais. Sāo värias as doenças que po dem ser veiculadas pela āgua, tanto pela ingestão como pelo con tato atravēs da pele e mucosas.

Por outro. lado, o consumo do oxigênio, consequência da estabilização da matêria orgânica pelas baçtêrias, resulta numa diminuição ou extinção do oxigênio dissolvido na ägua, pro 


\begin{tabular}{|c|c|c|}
\hline FONTES DE POLUICĀO DA ÁGUA & POLUENTES & IMPACTOS QUALITATIVOS \\
\hline $\begin{array}{l}\text { - DESCARGA DE ESGOTOS DOMÉSTICOS } \\
\text { - DESCARGA DE ESGOTOS INDUSTRIAIS } \\
\text { - DESCARGA DE GALERIAS DE ÁGUAS PLUVAIS } \\
\text { - ÁGUAS DE ESCOAMENTO SUPERFICIAL } \\
\text { - ÁGUAS DE INFILTRACĀO } \\
\text { - INTRUSĀO DE ÁGUA SALGADA } \\
\text { - LANGAMENTO DIRETO DE DETRITOS }\end{array}$ & $\begin{array}{l}\text { - BACTÉRIAS, VIRUS E OUTROS ORGANISMOS } \\
\text { PATOGẼNICOS. } \\
\text { - COMPOSTOS OROĀNICOS } \\
\text { - COMPOSTOS INORGĀNICOS } \\
\text { - NUTRIENTES } \\
\text { - METAIS PESADOS } \\
\text { - COR E TURBIDEZ } \\
\text { - ODOR } \\
\text { - TEMPERATURA } \\
\text { - SÓLIDOS DISSOLVIDOS E EM SUSPENSÃO } \\
\text { - FERTILIZANTES E DEFENSNOS AGRICOLAS }\end{array}$ & $\begin{array}{l}\text { - PREJUIZZOS A SAÚdE PÚBLICA } \\
\text { - REDUÇÃO DO OXIGẼNIO DISSOLVIDO NA } \\
\text { ÁGLA. } \\
\text { - DANOS ECOLÓGICOS À VIDA AOUÁTICA } \\
\text { - PREJUIZOS AOS USOS DEFINIDOS PIA ÁGUA } \\
\text { - ASSOREAMENTO } \\
\text { - EUTROFIZACĀO } \\
\text { - ASPECTO ESTÉTICO DESAGRADÁVEL } \\
\text { - REFLEXOS ECONŌMICOS }\end{array}$ \\
\hline
\end{tabular}

$r$ FONTES DE POLUICÃO DA ÁQUA, POLUENTES E IMPACTOS QUALITATIVOS 
vocando desequilíbrios ecológicos no meio, com prejuízos para os peixes e outros organismos aquáticos.

os esgotos domésticos provocam outras alterações nas características da água, relacionadas com a cor, turbidez,odor, sölidos, compostos químicos, entre outros.

A composição dos resíduos domésticos é variável, em função da concentração do esgoto, a qual depende do volume de á gua distribuido por habitante. No entanto, algumas caracterist cas podem ser estimadas, tais como:

Alcalinidade $\left(e \mathrm{CaCO}_{3}\right)$ : superior a $100 \mathrm{mg} / 1$

Cloretos: em torno de $75 \mathrm{mg} / 1$

Demanda Bioquímica de oxigênio ( 5 dias, $20^{\circ} \mathrm{C}$ ): em mê dia atinge a $300 \mathrm{mg} / 1$

Nümero de coliformes: $10^{5}$ a $10^{6}$ por mililitro

os esgotos industriais têm composição bastante varia da, dependendo do tipo de processamento utilizado. De um modo geral, podemos dizer que alguns resíduos líquidos industrials são caracterizados por:

- Demanda Bioquímica de oxigênio elevada, causando a redução do oxigênio dissolvido da água

- Presença de compostos químicos tóxicos e metais pe sados

- Cor. Turbidez e Odor indesejäveis

- Temperatura elevada, provocando desequilíbrios eco lögicos no corpo receptor

- Nutrientes em excesso, causando a eutrofizaçäo da ăgua, com prejuízos aos seus usos

- Sölidos dissolvidos e em suspensão

- Acidos e ālcalis, com efeitos sobre o pH da água

- Oleos, graxas e similares

Estas características, varíáveis para cada tipo de indüstria, provocam alterações no meio aquätico, prejudicando o seu uso pelo homem, e afetando os organismos que vivem na água.

Como fonte localizada de poluição da ãgua, relaciona mos, também, os lançamentos de águas pluviais, atravēs de ga 
lerias. Este liquido pode conter impurezas carreadas pela àgua no escoamento superficial, conforme veremos a seguir. $E$ comum, tambēm, a existềncia de ligaçōes clandestinas de tubulaçöes de esgotos doméstlcos e industrials a estas galerlas; cohtribuindo assim para prejudicar a qualidade do líquido.drenado.

4.312:2 - Fontes não localizadas de poluição da āgua

4.3.2.2.1 - Agua de escoamento superficial

A ägua que precipita em uma ärea urbana e escoa pela superficie pode conduzir uma grande variedade de impurezas.

A concentração de impurezas neste líquido é bastante variàvel e depende, principalmente, de:

- Uso do solo: residencial, comercial, industrial ou outros

- Atividades desenvolvidas pelo homem, na ārea: cons truções, movimentos de terra, träfego de veículos, etc.

- Fatores hidrolögicos: duraçẽo, quantidade e fre quência da precipitação pluvial

- Características do ambiente físico: ärea pavimenta da ou coberta, tipo de pavimentação ou cobertura, vegetaçäo presente, estrutura e composição do solo

Esta sërie de fatores contribui para uma grande va riação das características da àgua de escoamento superficial. conforme pode sar constatajo no QUADRO 4.8. Como se pode obser var, é difícil prever a composição da água escoada em determina da ärea, devido a grande variedade de fatores intervenientes.

De um modo geral, as àguas de escoamento superficlal podem ser caracterizadas por:

- Sólidos sedimentäveis, de vários tipos e tamanhos

- Matêria orgãnica

- Nutrientes, principalmente fösforo e nitrogênio

- Defensivos agrícolas e fertilizantes 
- Bactërias e organismos patogênicos

- Värios compostos químicos

- Metais pesádos

Este líquidoj atingithdo coleçōes superficials ou in fíttrando-se ro terreño atè alcançar a ảgua subterránea,pode re sultat ent

- Efeitos negativos sobre à saúde humana

- Diminuição do oxigênio da ägua

- Danos ecológicos, com refiexos sobre a fauna e a flora aquäticas

- Assoreamento

- Excessiva turbidez

- Eutrofizaçäo

$$
\text { QUADRO } 4.8
$$

Caracteristicas da ägua de escoamento superficial em äreas urbanas

\begin{tabular}{|c|c|c|}
\hline CARACTERPSTICAS & VAR & AçÃO \\
\hline $\mathrm{DBO}_{5}(\mathrm{mg} / 1)$ & 1 & -700 \\
\hline $\mathrm{D} 2 \mathrm{O}^{\circ}(\mathrm{mg} / \mathrm{l})$ & & $=3.100$ \\
\hline Sölidos em suspensäo totais (mg/l) & 2 & -11.300 \\
\hline Sölidos totais $(\mathrm{mg} / \mathrm{l})$ & 450 & -14.600 \\
\hline Sölidos volateis totais $(\mathrm{mg} / \mathrm{l})$ & 12 & -1.600 \\
\hline Sölidos sedimentäveis $(\mathrm{mg} / \mathrm{l})$ & 0,5 & -5.400 \\
\hline Witrogènio orgānico $(\mathrm{mg} / \mathrm{l})$ & 0,1 & -16 \\
\hline $\mathrm{NH}_{3}(\mathrm{mg} / \mathrm{l})$ & 0,1 & -25 \\
\hline $\mathrm{PO}_{4}^{\prime}$ solüvel $(\mathrm{mg} / \mathrm{l})$ & 0,1 & -10 \\
\hline $\mathrm{PO}_{4}^{4}$ total $(\mathrm{mg} / 1)$ & 0,1 & -125 \\
\hline Cloretos $(\mathrm{mg} / \mathrm{l})$ & 2 & -25.000 \\
\hline $01 \mathrm{eos}(\mathrm{mg} / 1)$ & $\mathbf{0}$ & -110 \\
\hline Fenöis (mg/1) & 0 & $-0,2$ \\
\hline Chumbo $(\mathrm{mg} / 1)$ & 0 & $-1,9$ \\
\hline Coliformes totais $(\mathrm{n}: / 100 \mathrm{ml})$ & 200 & $-146 \times 10^{6}$ \\
\hline Coliformes fecais $(\mathrm{n}: / 100 \mathrm{ml})$ & 55 & $-112 \times 10^{6}$ \\
\hline Estreptococus fecais $(\mathrm{n}: / 100 \mathrm{ml})$ & 200 & $-1,2 \times 10^{6}$ \\
\hline
\end{tabular}

FOHTE: U.S.A. WESTCHESTER COUNTY WASTE TREATMENT MANAGEMENT PLAî. (56) 
Durante a precipitação e o período em que a água es coa, a qualidade do líquido também varia. E claro que a ăgua es coada inicialmente carreia impurezas em maior quantidade, pois realiza uma lavagem do solo e áreas cobertas. Com o decorrer do escoamento, o líquido tem sua qualidade melhorada. Um exemplo que comprova esta observação são os dados do QuAdro 4.9, resul tantes de observações em uma cidade da Inglaterra.

Areas de maior densidade populacional são caracteri zadas por maior impermeabilizaçāo do solo e, portanto, maior es coamento superficial da ägua precipitada. A presença de resídu os sobilidos, detritos de animais e outras impurezas è comum na superfície destas āreas, contribuindo para uma pēssima qualida de das äguas de escoamento, principalmente nos momentos inici ais da precipitação.

A realização de abras de construção civil, com movi mentos de terra e alteraçōes nas condiçōes topogräficas, tem in fluência na qualidade da àgua escoada, podendo contribuir para grande carreamento de partículas do solo, provocando elevada turbidez no líquido.

Poluentes atmosfērios, resultantes de atividades in dustriais ou dos veículos automotores, podem ser carreados pe las chuvas, indo incorporar-se às águas de escoamento.

4.3.2.2.2 - Agua de infiltração

- Aspectos hidro-geolögicos

A ägua que se infiltra no solo, a partir da precipi tação, cursos d'ägua, lagos e reservatórios, contribue para a formação de aquíferos subterráneos.

Este líquido, quando originado de äguas polurdas, ou tendo percolado através de um meio contendo impurezas, constitui uma fonte de poluição da àgua subterrānea. 
QUADRO 4.9

Concentraçōes mēdias de alguns constituintes de äguas de enxur radas, em diferentes intervalos de tempo. Northampton, Inglater ra, 1963

\begin{tabular}{|c|c|c|c|c|c|c|}
\hline \multirow{2}{*}{\multicolumn{2}{|c|}{$\begin{array}{l}\text { INTERVALO } \\
\text { DE TEMPO } \\
\text { (minuto) }\end{array}$}} & \multicolumn{5}{|c|}{$C 0$ is $S T I T U 1$ iN $T E S(\mathrm{mg} / 1)$} \\
\hline & & $\begin{array}{l}\text { Sólidos } \\
\text { em sus - } \\
\text { pensão }\end{array}$ & DBO & $\begin{array}{l}\text { Oxigeñio } \\
\text { Consumi- } \\
\text { do }\end{array}$ & Ni trogênio & Cloretos \\
\hline 0 & -5 & 811 & 351 & 106 & 22,5 & 58,6 \\
\hline 5 & -15 & 754 & 288 & 90 & 18,5 & 54,2 \\
\hline 15 & -25 & 743 & 249 & 85 & 15,3 & 42,1 \\
\hline 25 & -35 & 626 & 203 & 73 & 12,2 & 37,0 \\
\hline 35 & -50 & 481 & 145 & 60 & 9,4 & 33,0 \\
\hline 50 & -70 & 319 & 99 & 44 & 7.9 & 27,0 \\
\hline 70 & -120 & 254 & 90 & 39 & 7,0 & 32,4 \\
\hline & $>120$ & 197 & 78 & 33 & 8,0 & 26.6 \\
\hline
\end{tabular}

FONTE: Dados colhidos por GAMESON e DAVIDSON e apresentados em $(10)$ 
A ägua move-se no solo, de duas formas:

(a) Para baixo, sob a açä̀ da gravidade, na zona nāo saturada, onde os vazios do solo ainda não estāo complètamente preenchidos pélo líquido.

(b) De acordo com a direção determinada pelas condi çöes hidräulicas, na zona saturada, onde ocupa todos os poros do terreno.

- limite entre as zonas saturada e não saturada é o chamado "nivel do lençol freätico".

A água subterrānea às vezes emerge do subtsolo, for mando nascentes ou descarregahdo em elementos de ăguas superf cials, tais como cursos d'àgua, lagos, lagoas e oceanos.

Assim, o lençol subterrāneo contribui para a manuten ção de cursos d'ägua perenes, quando o escoamento superficial é pequeno ou não existe. Alguns cursos d'ägua, no entanto,não são alimentados pela āgua subterrānea, devido a existência de ro chas impermeäveis pröximas à superfície. Isto é comum na regi ão Hordeste do Brasil, ficando os rios completamente secos, na ëpoca de estiagem.

Por sua vez, as coleções superficiais de àgua podem contribuir, tambēm, para o carregamento de lençois subterráneos pröximos às suas margens, nas zonas chamadas de aluviōes. Esta alimentação é acentuada quando se bombeia ăgua de poços nas pro ximidades de äguas superficiais.

A ägua retida na primeira camada da zona não satura da pode voltar à atmosfera pela evaporaçäo, a partir do solo, ou pela transpiração, através da vegetação.

\section{- Movimento de poluentes no sub-solo}

Existem värias maneiras da ägua subterrânea (e a par tir desta, a āgua superficial) ser poluída em um meio urbano, entre as quais destacamos:

- Atravēs de líquidos provenientes de fossas sēpti cas

- Por meio de líquidos percolados atraves de aterros 
de lixo ou oriundos de lagoas de estabilização, ir rigaça com àgua poluída, depositos de resíduos no clvos no solo, etci

- Injeção de resíduos ifquídos, domésticos ou indús triais, no sub-solo

- Carreamento de impurezas, defensivos agrícolas e fertilizantes lançados no solo

- A partir de coleções superficiais de āgua poluída

- Pela intrusão de ägua salgada no lençol subterrä neo

Na FIgura 4.7 estão indicados alguns modos de ocor rência da poluição do lençol freätico.

Muitos fatores influem no movimento da água contendo impurezas, no sub-solo. Em função dos mesmos, uma fonte de po luentes pode causar a contaminação da ägua subterrânea, prejudi cando o seu uso para diversos fins.

Entre os fatores envolvidos na contaminaçāo de aquí feros, enumeramos:

- Natureza do contaminante que percola junto com a àgua

- Hidräulica do sistema de escoamento: movimento da água no sub-solo. Este escoamento pode ser altera do pela açäo do homen, atravës de bombeamentos ou da injeção de líquidos

- Características físicas e quimicas do meio geológi co: porosidade, permeabilidade, composição quími ca. A porosidade está relacionada com a capacida de de armazenamento de āgua, enquanto que a permea bilidade relaciona-se com o movimento da àgua sub terrânea

- Processo natural de tratamento que ocorre no meio subterrāneo, através de mecanismos de filtração, ad sorçāo, troca de íons, diluição e dispersão.

Um aspecto importante a considerar no processo de in filtração da ăgua no sub-solo é a existência de fraturas em ro chas consolidadas, as quais poderão permitir a penetração do if 

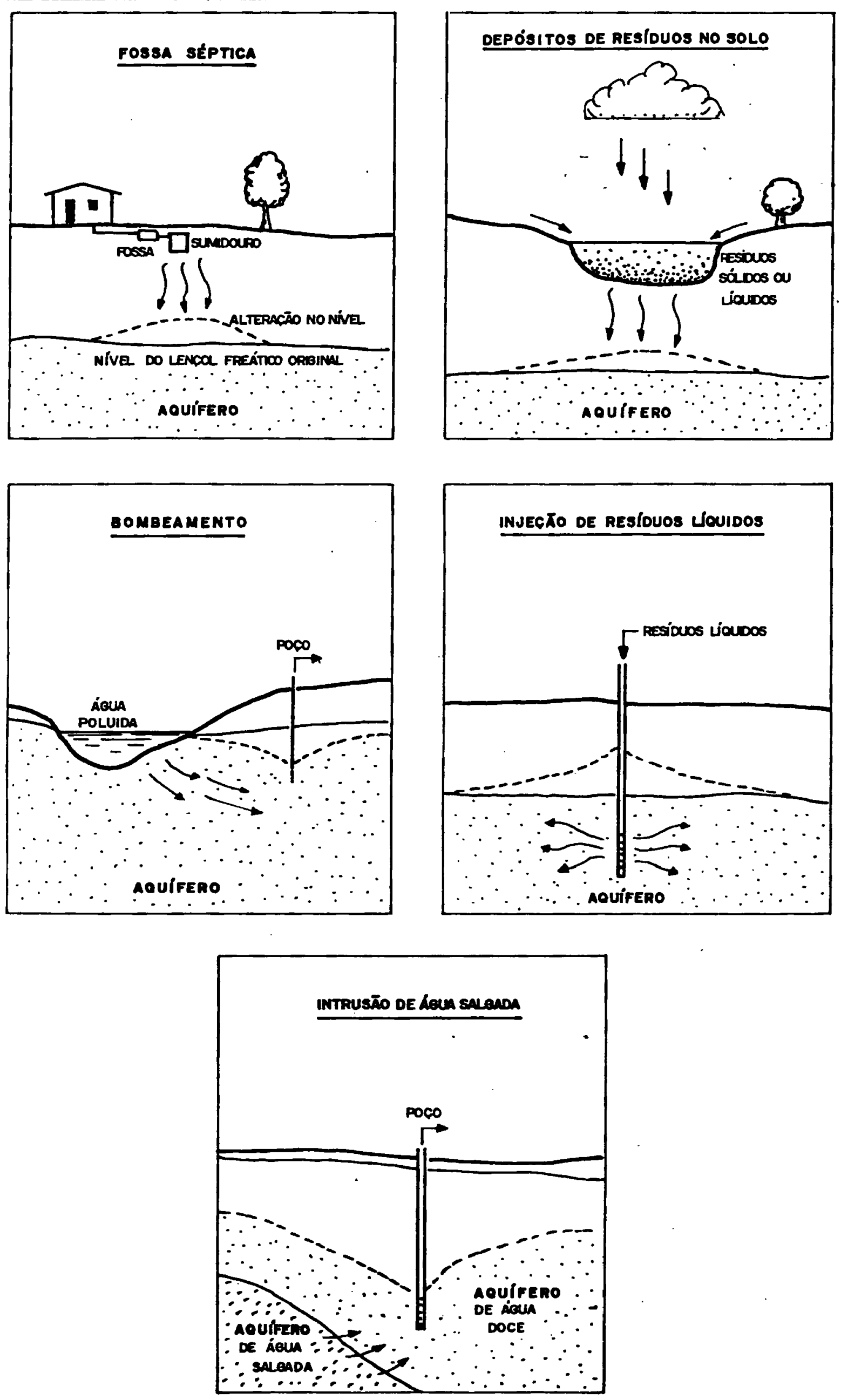

Ficura at

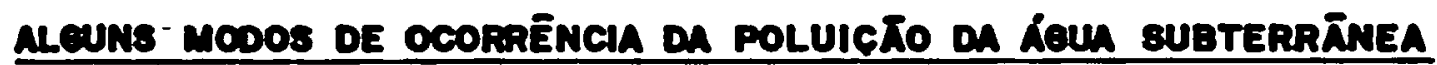


quido poluido a grandes profundidades ou distâncias.

Devemos considerar dois aspectos diferentes quando a nalisamos o movimento da àgua subterrânea:

(a) Péróolação do líquido na camada de solo nāo satü rada

(b) Des locamento da ägua na zona de saturação

De um modo gerali na zona não saturada o processo de purlficaçäo do líquido é mais intenso, havendo uma maior remo ção de poluentes para uma menor distancia percorrida. Isto acon tece devido havar malor quantidade de oxigênio nesta zona; favo recendo à decomposição aerōbia, mais räpida e completa. Por ou tro lado, em um fluxo em zona não saturada é maior a proporção entre a ärea de superfície das partículas e o volume de āgua que se escoa, favorecendo, assim, aos processos de adsorça e troca iônica.

o movimento de poluentes atravēs do sub-solo ven sen do estudado há algum tempo, em diversas partes do mundo.

Algumas destas pesquisas, relativas ao deslocamento de bactērias e vírus, foram comentadas por pomero, o qual che gou a importantes conclusōes, que julgamos bastante välido transcrever: (44)

1. Bactèrias e vírus deslocam-se com o fluxo da gua; eles não se movem contra a corrente

2. Bactërias e vírus podem se mover numa direçäo 응 posta àquela normal da āgua subterrânea, durante períodos de recarga ou bombeamento

3. Em geral, bactérias e vírus são removidos pelo a quífero do mesmo modo que são os coliformes

4. A taxa de remoçäo de bactérias e vírus, em função da distancia, depende de uma característica do a quífero chamada de "filtrabilidade"

5. Para um determinado grau de filtrabilidade a remo ção de poluentes ciepende, sobretudo, da distancia e não da taxo de recarga de poluentes

6. Materiais de aquíferos mais apropriados para a re moção de contaminantes biológicos säo aqueles com 
postos uniformemente de muito finos a finos grãos de areia com um alto conteüdo de argila

7. Para um sistema ideal, a máxima distância percor rida por poluentes biolögicos na ägua subterrânea varia entre 15 a 30 metros

8. A distâncla percorrida por estes poluentes em umá zona nāo saturada é consideravelmente menor que èm um sistema saturadol na zono näo saturada a distäncla mâxima percorrido pareco ser em torno de 3 metros

9. A natureza do solo em contato com a fonte de con taminação representa um papel dominante no subse quente movimento de bactérias

10. Poluentes compostos de bactérias elou virus podem alcançar distâncias muito maiores que as previa mente citadas se ajuas carregadas com nutrientes forem interceptadas durante o curso da penetração

11. Sob condições favorāveis, bactērias e vírus têm sido constatados como tendo sobrevivência superi or a 5 anos

As conclusões de ROMERO são muito importantes, pois chegam a prever distâncias mäximas a serem alcançadas por conte minantes biolögicos na água subterrānea. No entanto, como desta cado, estes contaminantes podem alcançar distâncias maiores, des de que condiçōes favoräveis permitam isto.

Podemos dizer que, devido a grande quantidade de fa tores intervenientes no processo, o mesmo alnda näo está comple tamente conhecido, havendo opiniões e resultados de experiénci as prätlcas os mais variados.

Um dos conhecimentos jä definidos è o de que as subs tâncias químicas presentes na àgua subterrânea, ao conträrio dos contaminantes biolōgicos, podem alcançar grandes distâncias no solo. Elas são diluidas na ägua mas não são comumente absor vidas pelo meio poroso.

Dados levantados por NEWEL e ALMQUIST e apresentados em (10) mostram distâncias de infiltração horizontal de poluen tes químicos variando de $90 \mathrm{~m}$ até $32.000 \mathrm{~m}$. 
No Condado de Allegan, Michigan, constatou-se que a descarga de resíduos contendo cromo em uma vala de infiltração no solo, causou a contaminação de um aquífero pelo menos até 300 metros de distáncia, em uma di reção, a uma profundidade de pelo menos 11 metros. Foram decorridos cerca de 3 anos para o poluente deslocar-se 300 metros, a uma taxa de cerca de 30 cen timetros por dia. (14)

o QUADRO 4.10, com dados transcritos de (42), mostra as distancias alcançadas por diversos contaminantes da ägua subterrānea atravēs de diferentes formaçōes geolögicas e duran te variados tempos de percurso. Podemos observar grandes distán cias alcançadas por substāncias químicas, e bactērias percorren do distancias maiores que as indicadas por ROMERO.

Vemos, então, que o líquido infiltrado no solo a par tir de aterros de resíduos sölidos, de depósitos de materiais tóxicos, de lagoas de estaúilização de esgotos domēsticos e in dustriais, ou de outros meios poluídos, pode alcançar grandes distãncios horizontais, carreando substāncias químicas.

4.3 .3 - Poluição do ar

As atividades desenvolvidas pelo homem, em àreas ur banas, resultam no lançamento de gases e particulas pequenas na atmosfera, alierando a qualidade do ar e provocando, portanto,a sua poluição.

Dependendo das condiçōes climäticas ou topogräficas, bem como do tipo e quantidade de poluentes lançados na atmosfe ra, os resíduos podem ser dispersos, não havendo consequéncias mais graves. Mo entanto, nem sempre ocorre esta dispersão dos polventes e a poluição do ar pode resultar em prejuízos à saūda humana, aos animais, aos vegetais a as materiais em geral. 


$$
\text { QUADRO } 4.10
$$

Distâncias a tempos de percursos alcançados por poluentes de àguas subterrāneas em diversas formações geológicas

\begin{tabular}{|c|c|c|c|}
\hline CONTAMINANTE & FORMAÇÃO GEOLOGICA & $\begin{array}{l}\text { DISTANCIA } \\
\text { ALCANCADA } \\
(\mathrm{m})\end{array}$ & $\begin{array}{l}\text { TEMPO DE } \\
\text { PERCURSO }\end{array}$ \\
\hline Gasolina & Calcärio fraturado & 3.200 & 5 anos \\
\hline Ácido pícrico & - & 4.815 & $4-6$ anos \\
\hline Fenol & Áreia e cascalho & 457 & $4-5$ anos \\
\hline Gasolina & Areia e cascolho & 701 & 7 anos \\
\hline Micro-organismos & $\begin{array}{l}\text { Areia, tamanho da } \\
\text { partícula } 0,17 \mathrm{~mm}\end{array}$ & 3 & - \\
\hline Bactēria coliforme & $\begin{array}{l}\text { Areia, tamanho - } \\
\text { efetivo } 0,13 \mathrm{~mm}\end{array}$ & 20 & 27 semanas \\
\hline Compostos químicos & $\begin{array}{l}\text { Areia, tamanho - } \\
\text { efetivo } 0,03\end{array}$ & 35 & 27 semanas \\
\hline Bactéria coliforme & Areia fina & 122 & - \\
\hline Efluente de lodos & Areia fina & 457 & - \\
\hline
\end{tabular}

FONTE: PARKER, H.W. 1975 (42) 
Assim sendo, podemos dizer que a poluiçāo do ar de pende, sobretudo, de:

(a) Fontes de emissão de polulção - tipos de poluen tes, período de emissäo, quantidades

(b) Caracteristicas climäticas do ambiente, contribu indo ou não para dispersar, transformar e remo ver os poluentes gerados pelas atividades urba nas

(c) Condiçōes topogräficas do meiol influlndo ha cí culaçāo do ar

Podemos observar que dos très fatores acima, somente a emissāo de poluentes está sós controle direto do homem. Os dois ültimos, que podemos chamar de fatores ambientais influin do no processo de poluição do ar, nāo dependem diretamente da agão do homem. E claro que o homem pode aproveitar-se das carac teristicas ambientais como medida preventiva contra a poluiça do ar. Pode, tambèm, favorecer a ocorrēncia de determinado fenô meno natural, como por exemplo criar condiçöes favoräveis a cir culaçāo e à maior ventilaçāo atmosférica. No entanto,estarā sem pre sujeito às condiçōes naturais, devendo amoldar-se àsmesmas.

4.3.3.1 - Emissão de poluentes

As principais fontes de poluentes atmisféricos säo:

(1) Fontes industriais, incluindo as fábricas e ou tros processos, tais como a queima de combustí veis derivados do petróleo em fornos, caldeiras, etc.

(2) Transporte, compreendendo os veículos automoto res de värios tipos e o trä́fego aéreo

(3) Outras fontes, tais como: incineração dos resídú os sōlidos; perdas, por evaporaçāo, em serviços petroquímicos; queima de combustíveis para aque cimento de edificaçōes.

Os meios de transporte constituem a maior fonte de poluição do ar nas grandes cidades. A FIGuRA 4.8 apresenta pro 
porçōes de emissão de poluentes atmosfëricos na regiāo da Gran de sāo paulo, mostrando os veículos automotores como os maiores contribuintes. (38)

Dados da Agência de Proteção do Meio Ambiente dos Es tados Unídos da Amërica indicam, tamuèm, uma grande porcentagem para os poluentes oriundos dos meios de transporte,conforme mos tra ä FIGURA 4.9. (40)

As fäbricas e outras fontes estacionarias de queima de combustívels contribuem, tambèm, com grande parcela dos polu entes atmosféricosi

Todas estas fontes de poluiçäo lançam diversos tipos de poluentes na atmosfera, sendo os mais comulis, em äreas urba nas :

- Munöxido de carbono

- Hidrocarbonetos

- Oxidos de nitrogênio

- Oxidantes fotoquímicos

- Oxidos de enxofre

- Material particulado

os meios de transporte contribuem, principalmente, com os seguintes poluentes: monóxido de carbono, öxidos de ni trogēnio, hidrocarbonetos e oxidantes fotoquímicos. Jā as fon tes industriais são responsäveis, geralmente, pela emissão de öxidos de enxofre, material particulado, óxidos de nitrogênio e hidrocarbonetos.

Convém ressaltar que os oxidantes fotoquímicos nāo são emitidos palas fontes poluidoras. Eles são formados quando os hidrocarbonetos e os óxidos de nitrogênio misturam-se, na pré sença da luz solar.

Dados coletados na Raia de São Francisco, nos Esta dos Unidos, constantes do QUADRO 4.11, indicam as diversas pro porçōes para poluentes atmosfēricos, oriundos dos meios de transportes (incluindo o tráfego aéreo) e de outras fontes. 

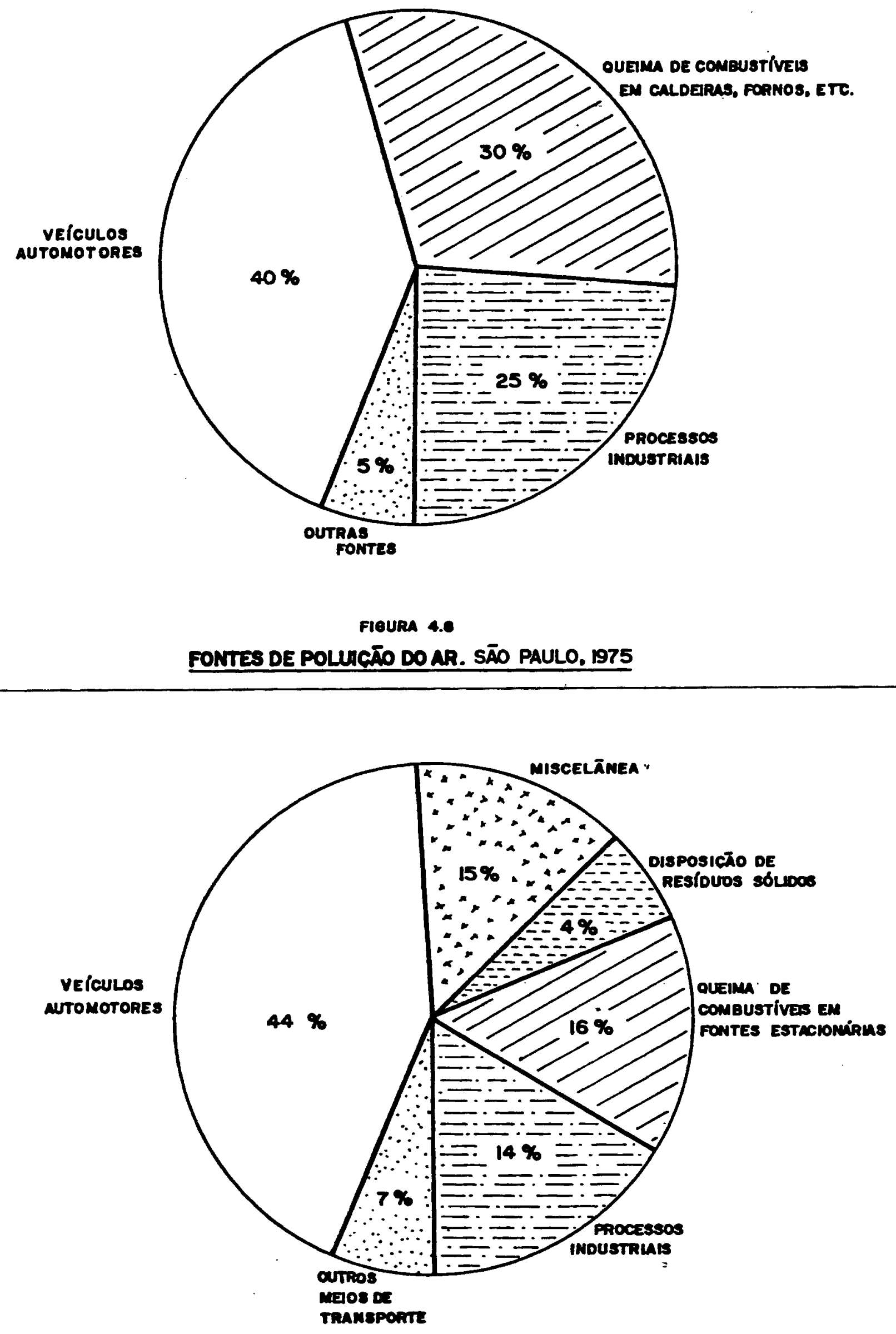

Fieura 49 


\section{QUADRO 4.11}

Porcentagens de emissōo de poluentes, por fontes. Baía de säo Francisco, Estados Unidos, 1975

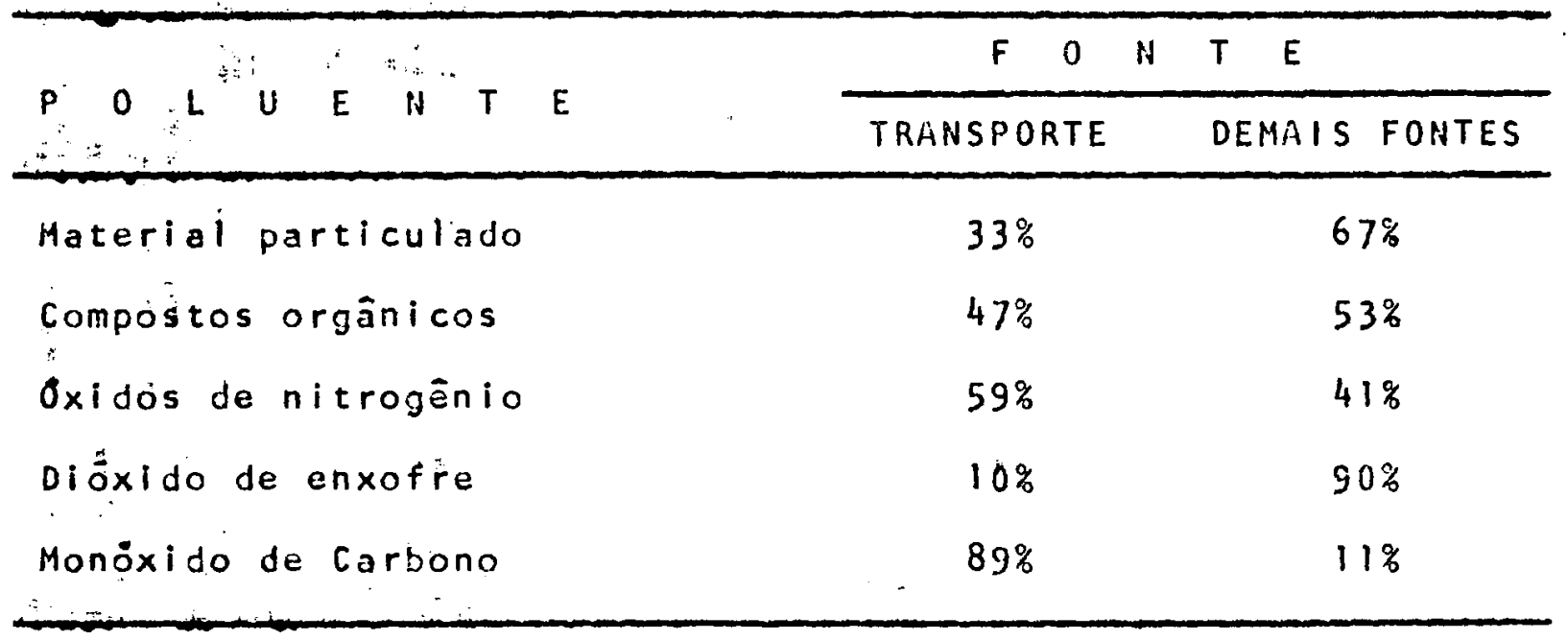

FONTE: SAH FRANCISCO BAY AREA POLLUTION CONTROL DISTRICT (2)

No QUADRo 4.12 é mostrads a distribulção das emls söes de poluentes atmosféricos, por tipo de fonte, na Regläo da Grande São Paulo.

Os dados deste Quadro indicam, realmente, uma grande contribuiçāo dos veículos na emissão de determinados poluentes: $95 \%$ de monōxido de carbono, $78 \%$ dos óxidos de nitrogênio e 73\% dos hidrocarbonetos constatados na Regijo.

A queima de combustivel em fontes estacionärias è responsävel por $83 \%$ dos öxidos de enxofre e por $20 \%$ dos öxidos de nitrogênio.

Jä os processos e operaçōes industriais contribuem com a maior parcela do material particulado (74\%, do total), con tribuindo com $17 \%$ dos hidrocarbonetos.

os dados dos QuAoros 4.11 e 4.12 nos dão uma idëia da distribuiçäo de poluentes, por fontes, em duas regiōes metro politanas. Estas informaçōes são ūteis na orientaçāo de progra mas de controle da poluição atmosférica. 
Distriulição das emissöes por tipo de fonte de poluição do ar,na Regiäo da Grande são Paulo. 1978 (Dados em t/dia)

\begin{tabular}{|c|c|c|c|c|c|c|c|c|c|c|c|}
\hline \multirow[b]{2}{*}{ FONTE } & \multirow{2}{*}{$\begin{array}{l}\text { MATERIAL } \\
\text { t/dia }\end{array}$} & \multicolumn{2}{|c|}{ PARTICULADO } & \multirow{2}{*}{$\begin{array}{l}\text { Oxido } \\
\text { t/dia }\end{array}$} & \multirow{2}{*}{$\begin{array}{l}\text { ENXOFRE } \\
\% \text { do } \\
\text { total }\end{array}$} & \multirow{2}{*}{$\begin{array}{c}\text { MONÓX100 } \\
t / \mathrm{dia}\end{array}$} & \multirow{2}{*}{$\begin{array}{l}\text { CARBOHO } \\
\% \text { do } \\
\text { total }\end{array}$} & \multirow{2}{*}{$\begin{array}{l}6 \times 100 \\
t / d i a\end{array}$} & \multirow{2}{*}{$\begin{array}{l}\text { NITROGENIO } \\
\% \mathrm{do} \\
\text { total }\end{array}$} & \multicolumn{2}{|c|}{ HIDROCARBONETOS } \\
\hline & & $\%$ do & total & & & & & & & $t / d i a$ & $\begin{array}{l}\% \text { do } \\
\text { total }\end{array}$ \\
\hline $\begin{array}{l}\text { Processcs e operações } \\
\text { Industriais }\end{array}$ & 399 & 74 & $;$ & 18 & 3 & 86 & 2 & - & - & 127 & 17 \\
\hline $\begin{array}{l}\text { Queima du combusti- } \\
\text { veis em fontes esta- } \\
\text { cionárias }\end{array}$ & 28 & 5 & & 551 & 83 & 19 & - & 62 & 20 & 9 & 1 \\
\hline Vef́culos Diesel & 10 & 2 & & 57 & 9 & 163 & 4 & 111 & 34 & 27 & 4 \\
\hline Veículos a gasolina & 23 & 4 & & 31 & 5 & 4268 & 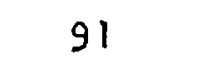 & 142 & 44 & 504 & 69 \\
\hline Queima de reif́duos & & & & & & & & & & & \\
\hline sölidos & 32 & 6 & & 1 & - & 120 & 3 & 7 & 2 & 39 & 5 \\
\hline outros & 51 & 3 & & - & - & - & - & - & - & 27 & 4 \\
\hline$T O T A L$ & 543 & 100 & & 648 & 100 & 4656 & 100 & 322 & 100 & 733 & 100 \\
\hline
\end{tabular}


os poluentes atmosfëricos, quando em concentraçós é levadas e quando expostos por determinados períodos de tempo; produzem efeitos desagradáveis no meio ambiente, tais como:

(a) Danos à saüde humana, contribuindo para maior in cldência de doenças respiratörias, irritaçōes nos olhos e pul mö́s, podendo causar até a morte. E difícil avaliar os efeitos da poluição do ar sobre a saüde humana, pois não é fäcil sepa rä-la de outras causas. Por outro lado, os efeitos desta polui çăo podem ocorrer a longo prazo, dificultando ainda mais a ava $1 \mathrm{i}$ àção.

(b) Redução da visibilidade, causada,principalmente, pela preseriça de materlal particulado na atmosferá o dióxido de nitrogentio, devido sua cor escura e contribuindo para a for mação de oxidantes fotoquímicos, é responsävel, também,por este efeito:

(c) Danos abs animais. Os animais, assim como o ho mem, sofrem os efeitos los poluentes atmosfëricos ocorrenda a morte de muitos deles em situaçóes graves de polulção do ar.

(d) Prejuízos aos materiais, tais como: corrosão do ferro, aço e mārmore; deterioração da borracha, produtos sinté ticos e tecidos; sujeira de roupas, predios e monumentos.

(e) Danos aos vegetais, causando a descoloroção de folhas e flores, queda de folhas, falnas na floração e produção de frutos, mal formação a a é mesmo a morte de plantas.

No QUADRO 4.13 apresentamos um resumo dos principais poluentes encontrados em um meio urbano, suas fontes e seus e feitos sobre o ambiente. 


\begin{tabular}{|c|c|c|}
\hline$P O=U E N T E S$ & $F O N T E S$ & 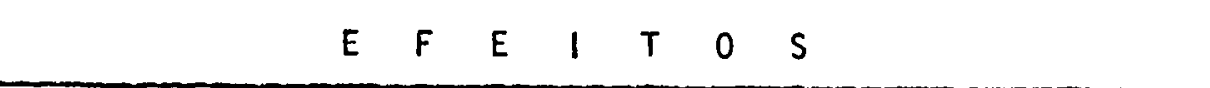 \\
\hline$\because$ ONOY!DO DE CARBOHO & - VETCULOS AUTOMOTORES & $\begin{array}{l}\text { - Em nivel mals baixo: agrava o coração e reduz } \\
\text { a habilidade de funcionamento do cerebro: } \\
\text { - Em concentrações muito altas: pode causar mor } \\
\text { te. }\end{array}$ \\
\hline HIOROCARROHETOS & $\begin{array}{l}\text { - VETCULOS AUTOMOTORES } \\
\text { - PROCESSOS INDUSTRIAIS }\end{array}$ & $\begin{array}{l}\text { - Maior componente do "smog" (oxidantes foto- } \\
\text { quimicos) } \\
\text { - Alguns hidrocarbonetos säo suspeitos de causa } \\
\text { rem o cancer. }\end{array}$ \\
\hline ORILJ TE HITROGENIO & $\begin{array}{l}\text { - VETCULOS AUTOMOTORES } \\
\text { - PROCESSOS INDUSTRIAIS }\end{array}$ & $\begin{array}{l}\text { - Combina-se com os hidrocarbonetos para formar } \\
\text { os oxidantes fotoquimicos ("smog"). } \\
\text { - o dioxido de nitrogenio causa dificuldades - } \\
\text { resplratórias, diminuindo a resistencia a pneu } \\
\text { monia a a gripe. }\end{array}$ \\
\hline $\begin{array}{l}\text { OXIDANTES FOTOQUTMICOS } \\
\text { ("SHOU") }\end{array}$ & $\begin{array}{l}\text { - FORMADO QUANDO OS HIOROCAR } \\
\text { BONETOS E OS OXIDOS DE NI } \\
\text { TROGENIO REAGEM EH PRESEN } \\
\text { CA DA LUZ SOLAR } \\
\end{array}$ & $\begin{array}{l}\text { - Irritam severamente os olhos e pulmōes } \\
\text { - Extremamente nocivo j́s plantas } \\
\text { - Deterioram a borracha, produtos sintéticos e } \\
\text { tecidos. }\end{array}$ \\
\hline OX!DOS DE ENXOFRE & $\begin{array}{l}\text { - QUEIMA DE OLEOS COMBUSTTVEIS } \\
\text { - QUEIMA DO CARVÃO } \\
\text { - PROCESSOS INDUSTRIAIS }\end{array}$ & $\begin{array}{l}\text { - Irrita o aparelho respiratório } \\
\text { - Causa irreversível dano aos pulmöes, quando- } \\
\text { combinado com material particulado. } \\
\text { - Corrói o ferro, oço e mármore } \\
\text { - Etóxicopara as plantas } \\
\end{array}$ \\
\hline MAAIERIAL $A A R T I C U L A D O$ & $\begin{array}{l}\text { - VETCULOS AUTOMOTORES } \\
\text { - PROCESSOS INDUSTRIAIS }\end{array}$ & $\begin{array}{l}\text { - Suja, com fuligem, as roupas, os prédios a } \\
\text { paisagem urbana } \\
\text { - Produz bruma e reduz a visibilidade } \\
\text { - Carreia poluentes toxicos para os pulmóes } \\
\end{array}$ \\
\hline
\end{tabular}


o mais importante na avaliação da poluição do ar é a determinação da concentração de poluentes em determinado local, muito mais do que a quantidade de poluentes emitida por uma fon te especifica.

A atmosfera e o agente que transporta e dispersa os poluentes entre as fontes e as äreas receptoras. Assim, as con dições atmosféricas desempenham papel importante na poluição do ar, podendo contribuir para diminuir ou aumentar a concentraça de poluentes em determinada ärea.

Geralmente, três parâmetros são importantes na des crição do processo de transporte e dispersão de poluentes atmos féricos:

- a velocidade do vento

- a direção do vento

- a estabilidade atmosfērica

os dois primeiros estão relacionados com o transpor te e dispersão horizontal dos poluentes, enquanto que a estabi lidade atmosfērica interessa ao movimento e dispersão no senti do vertical.

Quanto maior for a velocidade do vento, maior sera o volume de ar fornecido para diluição dos poluentes. Imaginemos uma área sobre a qual o vento circula com uma velocidade duas vezes superior do que em outra zona. E claro que na área de ven to com maior velocidade, para um mesmo periodo, a quantidade de ar que circula sobre ela é duas vezes maior. Portanto, è forne cido o dobro de volume de ar para dispersão dos poluentes.

A direção do vanto determina que ärea em torno da fonte de poluiçäo receberá os poluentes. Devemos observar que o ar não circula permanentementa em uma determinada direção. Embo ra exista uma direção na qual ele circula mais, chamada "dire ção predominante dos ventos", devem ser consideradas as mudan ças de direção na determinação das āreas sujeitas a receber po luentes, a partir de determinada fonte.

Normalmente, a temperatura da atmosfera decresce com a altura, ficando as camaas mais frias de ar sobre as camadas mais quentes. Nesta condição, hä um movimento ascendente do ar, a partir da superficie da terra, conforme mostrado na flG 
RA 4.10 (a).

Quando a temperatura decresce muito pouco, permanece a mesma ou é maior em camadas superiores, dizemos que a atmosfé ra é estável. Neste caso, è dificultado o movimento do ar para cima.

A situação em que hä uma camada de ar quente sobre uma de ar frio é chamada de "inversão de temperatura"lou lnver são de camada ou inversão térmical. Quando isto ocorre, o pra blema da poluição do ar é extremamente agravado, pois a concen tração de poluentes aumenta nas proximidades do solo, jä que não existem condições de dispersão. (FIGURA 4.10 (b))

As condições topogräficas influem, tambèm, na velocí dade e direção do fluxo da ar. Elevações do solo (montanhas), áreas baixas (vales), cursód'ägua, bem como alterações provo cadas pelo homén, tais como as edificações de alto porte, têm grande influência na circulação do ar.

Has proximidades de grandes coleçōes de água, em de terminados períodos do dia, hä uma brisa local, a qual pode in fluenciar a dispersão de poluentes da atmcsfera.

o movimento do ar em áreas de montanhas e vales va ria durante o dia e a noite, conforme indicado nas figuras 4.11 (a) e (b).

A noite, quando a terra e o ar nas proximidades res friam, o ar mais frio tende a mover-se para as áreas mais bai xas do vale. Este processo favorece jocorrência do fenômeno da inversão de temperatura, pois o ar mis quente permanece acima do vale. Há, assim, no período noturno, uma maior concentração de poluentes no vale.

Durante o dia, quando ocorre o aquecimento do ar, es te tende a subir, permitindo a dispersão dos poluentes, Ho en tanto, isto nem sempre acontace pois è comum ocorrerem períodos de grandes pressōes sobre estas regiöes, forçando a estagnação do ar e, portanto, favorecendo ao acúmulo de poluentes no vale.

outra situação que pose ocorrer è a mostrada na figu RA 4.12, quando a existência de montanhas junto a fontes de po luiçāo do ar impede a dispersāo horizontal dos poluentes, sendo favorecida a ocorrência de inversões.

Em cidades, as construçöes formam novas elevações no solo, alterando a topografia inicial. Isto contribui para modi ficar a circulaçäo e a velocidade do vento. 


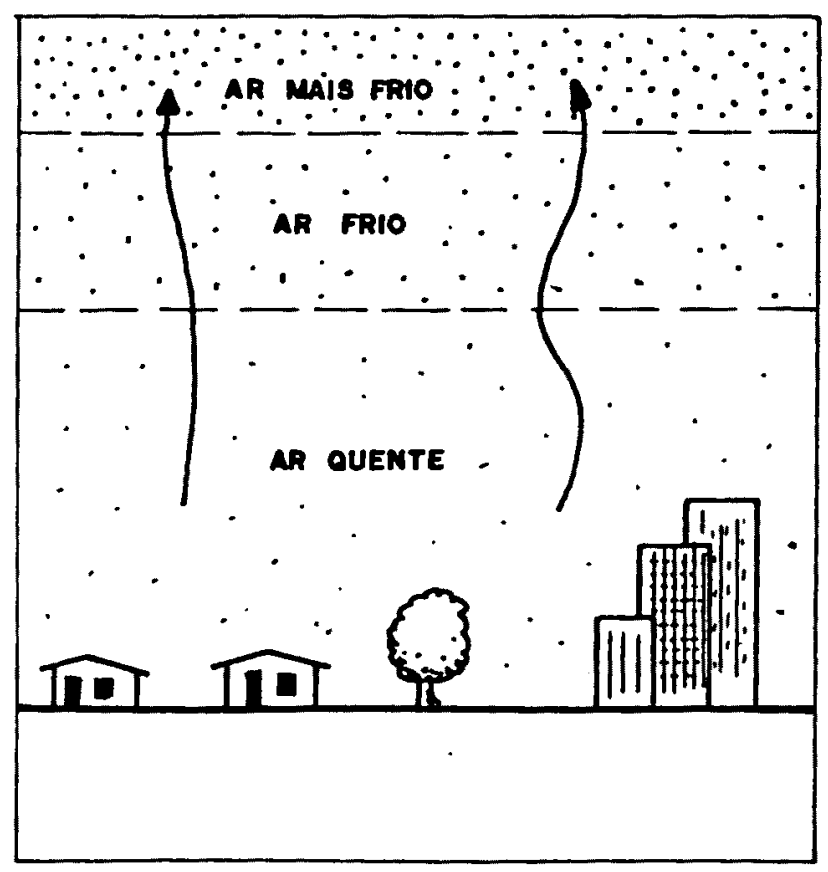

FIBURA $4.10(0)$

CAMADAS ATMOSFÉRICAS

CONDICŌES NORMAIS

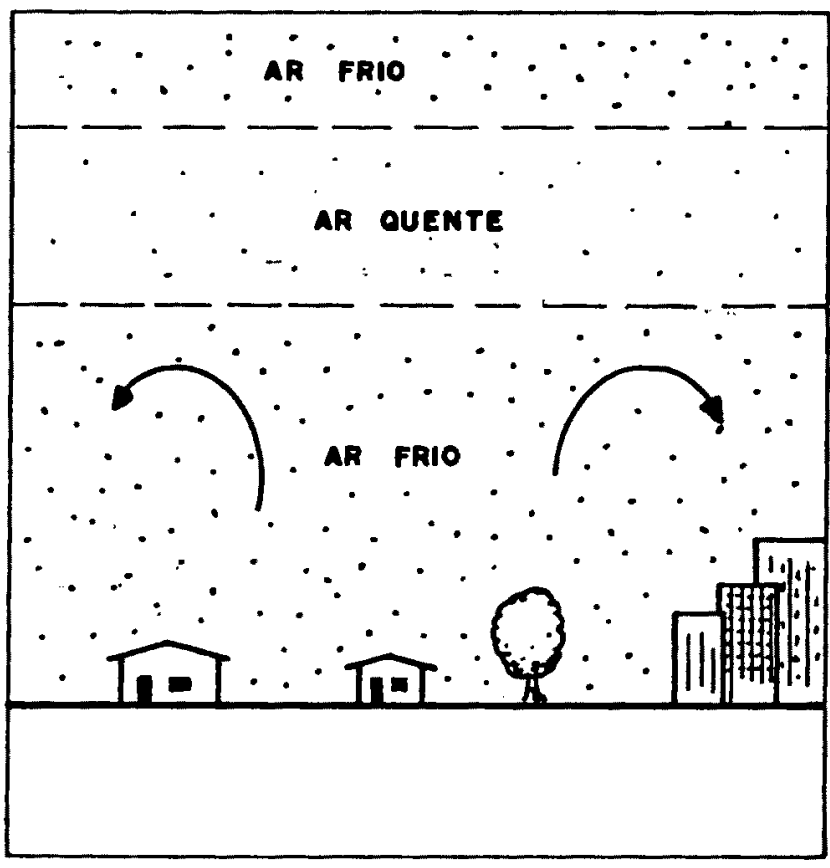

FIOURA $4.10(b)$

CAMADAS ATMOSFÉRICAS

INVERSĀO DE TEMFERATURA

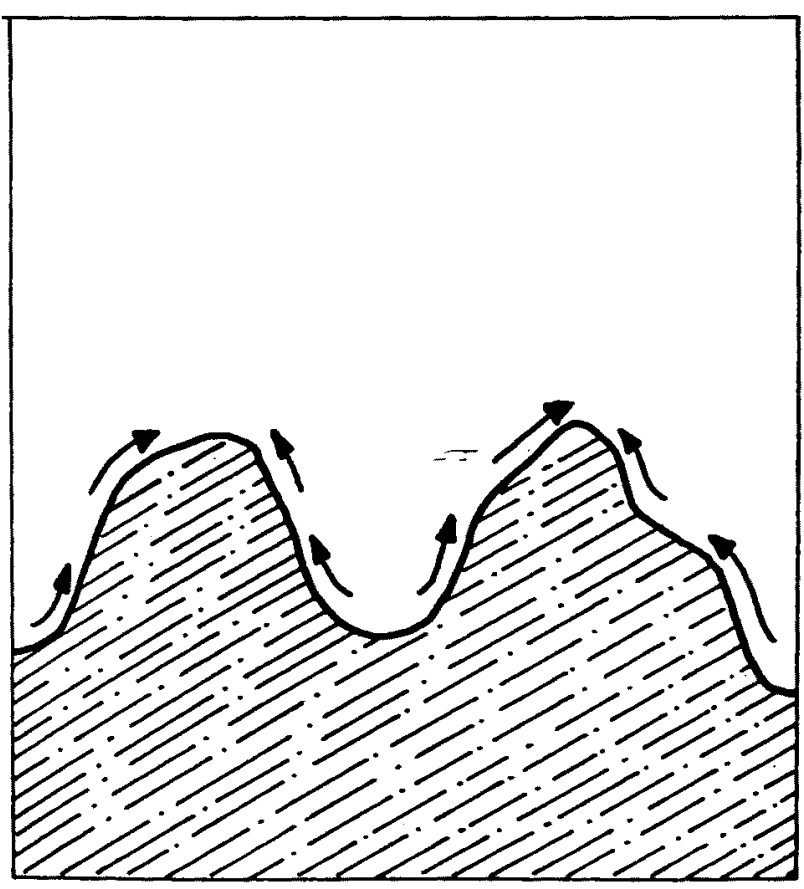

FIEURA 4.E (a)

MOVIMENTO DO AR EM MONTANHAS

E VALES - PERIODO DIURNO

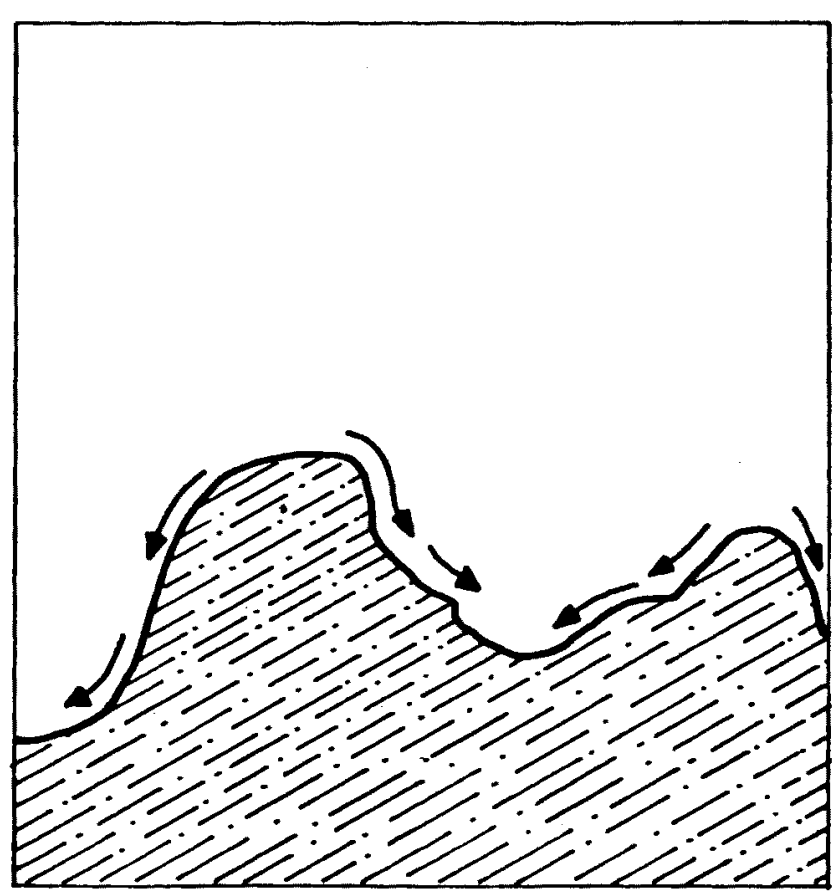

FIOURA S.II (D)

MOVIMENTO DO AR EN MONTANHAS

E VALES - PERIODO NOTURNO 
Prëdios altos em filas, uns frente aos outros, produ zem o efeito de "encanamento" do ar. Edificeçōes de grande altú ra mudam o fluxo de ar, provocando regiōes de redemoinhos.

outro fenómeno bastante conhecido em cidades è o que os meteorologistas chamam de "efeito da ilha de calor", for mando o "domus de poeira".

0 ar quente tendé a sé concentrar no centro da cidade carreahdo com ele os poluentes. Nesta ärea, o ar expande-se, fluindo para äreas externasi onde $\dot{e}$ resfriado e precipita. 0 ar mais frio, o qual se move das äreas morginais em direçāo ao cen tro das cidades para substitulr o ar que se expande, carreia os poluentes, formando um sistema circulatório, conforme indicado na figura 4.13 .

Este sistema é afetado por ventos com altas velocida des. Neste caso, formam-se plumas de calor e poluiçao, as quais podem atingir äraas externas à cidade.

$4 \cdot 3.4$ - Poluị̧ão scūstica

o ruído em excesso é um fato comum em grandes centros urbanos. Várias atividades desenvolvidas pelo homem nas ci dades resultam na emissão de sons em altas intensidades, contri buindo para uma nova modalidade de poluição - e poluiçāo acústí ca (ou poluição sonora).

Em um meio urbano, as principais fontes de poluiğāo acüstica são:

- Os meios de transportas terrestres

- O trä́fego aēreo

- Obras de construção civil

- Atividades industriais

- Aparelíos eletro-domésticos

- o próprio comportamento humano

Todas estas fontes produzem sons, os quais,quando em excesso, säo prejudiciais ao organismo humano. o principal efei to da poluiçäo acūstica é a perda gradativa da audição, fato jā comprovado em diversas pesquisas. Alēm disto, o barulho contri bui para outros sintomas, tais como a irritibilidade, incómodo, 


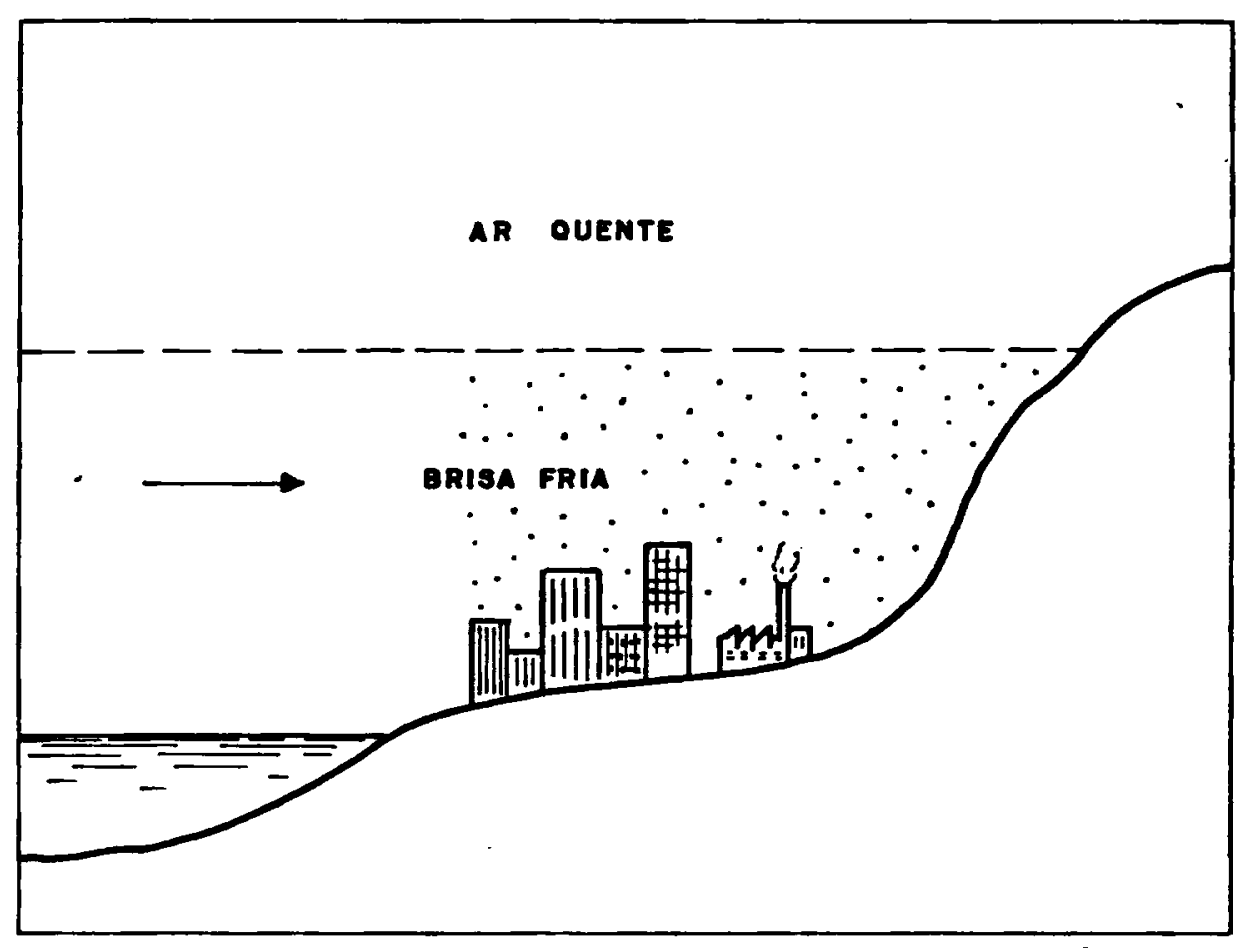

FIQURA 4.12

DISPERSÃO DE POLUENTES IMPEDIDA POR

MONTANHAS

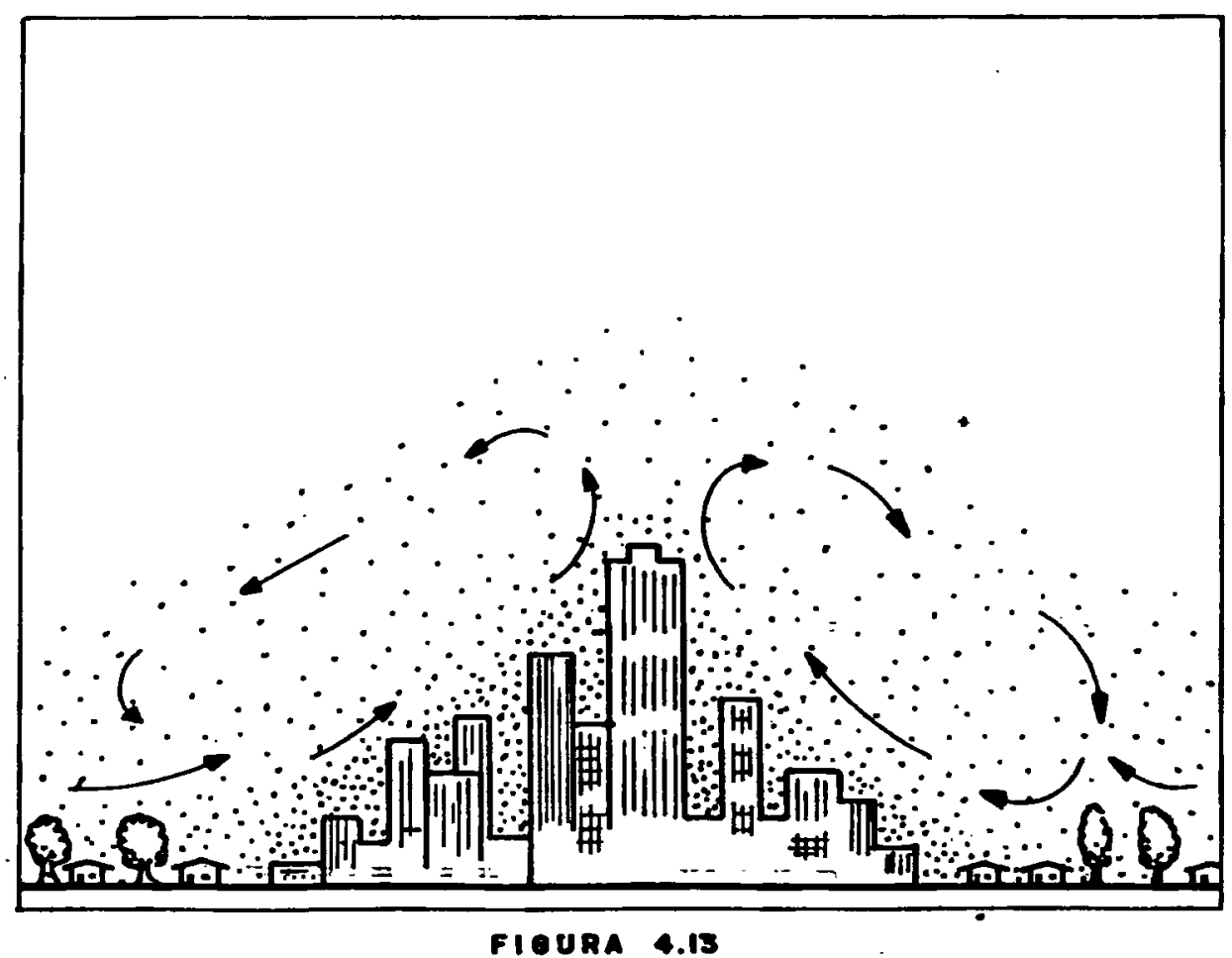

"domus de poeira". CIRCulacto do aR EM UMA CIDADE 
exaustāo física, distūrbios psíquicos, perturbaçōes do sistema nervoso central e até mesmo para perturbações cardíacas e circu látórias.

E importanta, portanto, considerar estes aspectoida poluiçăo acūstica em uma cidade, visando o bem-estar e a saúde da populaçäo.

Para adoçăo de uma política de combate ao barulho é necéssärio conhecer alguns aspectós relacionados com a emissão e medição do som.

o som é criado quando um objeto vibra e irradia par te de sua energia em ondas de pressöes acüsticas através de um meio, gasoso, liquido ou sölído. Ho caso da poluição acústica a que estamos nos referindo, esta transmissäo è feita, normalmen te, atravess do ar.

Este feriomeno é determinado por trás característi casl energla (intensidade), frequáncia e duraçăod

A fraquência do som é expressa em unidades Hertz (ci clos por segundo). A faixa de sons normalmente audíreis pelo ho mem varia de 20 a $20.000 \mathrm{~Hz}$.

A intensidade do som é expressa em unidades de pres são (pressão sonora). A magnitude desta pressāo é estabelecida em funçāo das pressōes de sons audíveis pelo homem, num interva lo entre o som mais fraco e o som mais forte. A amplitude deste intervalo é muito grande, variando numa faixa de 1 a cerca de 1.000 .000 unidades de pressão. Por isto, é difícil exprimir a intensidade do som em unidades de pressão.

A intensidade do som é expressa, então, em uma esca la logarítmica, a qual exprime o som numa uni lade chamada decí bel, que varia em um intervalo de zero a 200 , sendo, portanto, mais prätica.

Para melhor compreensão desta unidade, apresentamos no QUADRO 4.14, alguns sons comuns, resultantes de atividades humanas, com seus respectivos niveis em decibel. 


\section{QUADRO 4.14}

Niveis de Ruidos e efeitos sobre as atividades humanas

\begin{tabular}{|c|c|c|}
\hline SONS COMUNS & $\begin{array}{l}\text { VEIS EM } \\
\text { CIBEIS } \\
B(A)\end{array}$ & EFEITOS \\
\hline \multicolumn{3}{|l|}{$\begin{array}{l}\text { Jato em operação } \\
\text { Sirene de ataque aéreo }\end{array}$} \\
\hline \multirow{3}{*}{$\begin{array}{l}\text { Jato decolando a } 60 \mathrm{~m} \\
\text { Ribombo de trovoes } \\
\text { Discoteca } \\
\text { Buzina de carro a } 1 \mathrm{~m} \\
\text { Bate estacas }\end{array}$} & 130 & \\
\hline & 120 & Mäximo esforço vocal \\
\hline & 110 & \\
\hline Caminhão coletor de lixo & 100 & \\
\hline $\begin{array}{l}\text { Camintão pesado (a } 15 \mathrm{~m} \text { ) } \\
\text { Trāfego de cidades }\end{array}$ & 90 & $\begin{array}{l}\text { Muito incómodo } \\
\text { Danos ao ouvido (exposi } \\
\text { ção por } 8 \text { horas) }\end{array}$ \\
\hline $\begin{array}{l}\text { Despertador (a } 0,6 \mathrm{~m}) \\
\text { Secador de cabelos }\end{array}$ & 80 & Incômodo \\
\hline $\begin{array}{l}\text { Restaurante barulhento } \\
\text { Trāfego em uma auto-estrada } \\
\text { Voz humana (a } 1 \mathrm{~m})\end{array}$ & 70 & $\begin{array}{l}\text { Dificuldade em usar } \\
\text { telefone }\end{array}$ \\
\hline $\begin{array}{l}\text { Aparelho de ar condicionado } \\
\text { (a } 6 \text { metros) }\end{array}$ & 60 & Interferência \\
\hline $\begin{array}{l}\text { Träfego de veículos leves } \\
(\text { a } 30 \mathrm{~m})\end{array}$ & 50 & Calmo \\
\hline \multicolumn{2}{|l|}{$\begin{array}{l}\text { Sala de estar } \\
\text { Quartos } \\
\text { Escritōrio calmo }\end{array}$} & \\
\hline $\begin{array}{l}\text { Sussurro suave (a } 5 \mathrm{~m}) \\
\text { Biblioteco }\end{array}$ & 30 & Muito calmo \\
\hline \multirow[t]{3}{*}{$\begin{array}{l}\text { Estüdio de transmissão de } \\
\text { programa de rädio }\end{array}$} & 20 & \\
\hline & 10 & Justamente audivel \\
\hline & 0 & Limiar da audiçāo \\
\hline
\end{tabular}

FONTE: Agēncia de Proteção do Meio Ambiente dos Estados Unidos da América $(4,1)$ 
Os ruídos ou nivei de pressäo do som säo medidos a través de um aparelho conhecido como "sonômetro", o qual, normal mente, contém très escalas de frequēncia: $A, B$ e $C$.

A escala que representa o som de forma mais pröxima ao comportamento da audição humana é a chamada Curva $A$, a qual estä indicada no QUADRO 4.14, onde os níveis sonoros estão ex pressos em decibel A - CB(A).

Sendo logarítmica a Escala Decibel, qualquer peque no aumento em um valor significa um grande acréscimo de intensi dade do som.

o ouvido humano tambëm funciona como que logaritmica mente. Portanto, nossa percepção de aumento de som a de tal mo do que cada crescimento de 10 decibéis significa dobrar o som. Por exemplo, o som produzido por um caminhão pesado (expresso em 90 decibeis) parece ao nosso ouvido duas vezes maior que o barulho de um despertador (carrespondente a 80 decibēis).

As pessoas reagem diferentemente ao barulho. No en tanto, pode-se dizer que a partir do nível de 70 decibéis o ruí do começa a tornar-se prejudicial à audição humana. Existem va lores racomendados para niveis de ruidos em diversas atividades ou em função do períado do dia, os quais serão comentados poste riormente.

Sendo expressos em forma logarítmica, não se pode a dicionar sons de modo aritmético normal. For exemplo, quando dois caminhões pesados passam em uma rua, emitindo niveis de som correspondentes a 90 decibeis, cade um, não significa que os dois produzem um barulho total de 180 decibeis. os dois cami nhões corresponderiam a um nível combinado de 93 decibēis.

Ho QUADRO 4.15 indicamos alguns valores a serem adi cionados aos níveis de sons, no caso da combinaçäo dos mesmos. 


\section{QUADRO 4.15}

Regra de adição de decibéis, para combinação de niveis de sons

QUANDO DOIS MTVEIS DIFEREM DE:

ADICIONAR A SEGUINTE QUAN

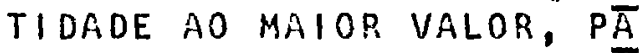
RA SE TER O SOH COHBINADO

$\begin{array}{ll}0 \text { ou } 1 \mathrm{~dB} & 3 \mathrm{~dB} \\ 2 \text { ou } 3 \mathrm{~dB} & 2 \mathrm{~dB} \\ 4 \text { a } 9 \mathrm{~dB} & 1 \mathrm{~dB} \\ 10 \mathrm{~dB} \text { ou mais } & 0 \mathrm{~dB}\end{array}$

FONTE: Agência de Proteção do Meio Ambiente dos Estados UnI dos da Amērica (3)

A intensidade do som varia, tambëm, com a distência, decrescendo inversamente com o quadrado da distancia a partir da fonte de ruído. Assim, cada vez que a distância dobra, a pres sāo sonora ë reduzida à metode. Este fenômeno significa um de créscimo de cerca de 6 deciuéis para cada vez que a distáncia a partir de uma fonte emissora de som é dobrada. (1)

o ruído, existente em um determinado local provém de värias fontes e varia durante determinado período de tempo. As sim, a sua avaliação não pode ser feita através de uma ünica me diçă. Por isto, foi instiuído o chamado "nível de som equiva lente", o qual pode ser definido como um nível de ruído tal que, em um determinado período de tempo, conteria a mesma energia so nora de värios barulhos diferentes ocorrendo no mesmo período.

Assim, a flutuação da níveis de ruído que ocorre em

um lugar, em determinado tempo, e represantada por um nivel fi xo equivalente, contando a mesma energia.

A iso - International Organization for Standardizati on dos Estados Unidos, sugere a adoção de um nivel equivalente $\left(L_{\text {eq }}\right)$. calculado atrovés da seguinte expressāo matemātica:

$$
\left.L_{e q}=10 . \log _{10}\left\{\frac{1}{N} f_{i} \cdot 10_{i}^{\frac{L L}{10}}\right)\right\}
$$


Onde:

$$
\begin{aligned}
N= & \text { nümero de amostras, para um determinado inter } \\
& \text { valo de tempo } \\
f_{i}= & \text { número de ocorréncias de um determinado nível, } \\
& \text { em dB(A), para aquele intervalo de tempo } \\
L_{i}= & \text { nivel de som em } d B(A)
\end{aligned}
$$

A determinação deste nivel equivalente foi felto na região da Grande São Paulo, nos muricíplos de Diadema, Mauá, San to Andrē, São Bernardo do Campoj São Caetano do Sul e São Pau $10 .(19)$

Os ciados deste levantamento foram coletados em áreas residenciais destes municípios, em intervalos de tempo de $15 \mathrm{mi}$ nutos, e estão indicados na Flguka 4.14.

Podemos observar que somente na ärea de Mauá o nível equivalente de ruídos não ultrapassou o mäximo recomendado pela 150, que é de $55 d B(A)$, para zonas residenciais.

\subsection{5 - Poluiçāo visual}

A ocupação desordenada de uma área urbana pode resul tar numa desfiguraçāo dà paisagem, constituindo a poluição ví sual.

Hormalmente, as alteraçoes estëticas do meio ambien te influem sobre o bem-estar das pessoas, pela forma agressiva como ocorrem, podencio, portanto, serem entendidas como uma moda lidade de polvição.

A ocupação desorjenada de äreas de vegetação densa, por construçōes, alēm de outros efeitos negativos já comenta dos, causa alteraçöes na paisagem, podendo destruir, total ou parcialmente, locais de grande beleza.

Nem sempre hä uma preocupação de efetuarem-se cons truçōes compondo a paisagem existente, procurando harmonizar a vegetaçāo natural com as edificaçōes.

Construçöes de prédios altos, criando barreiras em locais de onde se pode desfrutar de uma bonita vista, são co muns em cidades onde não hả uma preocupação com este aspacto. 


$$
\text { I1\|! }
$$


A extinção de plantas nativas, como resultado transformaçäo de äreas rurais em urbanas, é fato comum, muitas vezes irraversível, no processo de ocupação urbana.

os equipamentos urbanos säo; quase sempre, dispostos nas cidades sem haver uma preocupaça com cs aspectos estët cos, criando ambientes de feiça bastante desagradála às peśsoas.

A disposição de restrduos sôlidos ou liquidos, no so 10, alèm de outras consequências desagradáveis, contribui para a poluição visual.

A forma inadequada de depositar resíduos sailidos em terrenos baldios é uma prática comum nas cldades, causando as pectos estéticos desagradävis e contribuindo pata a desvalorl zação de äreas adjacentes.

As técnicas de propaganda utilizadas atualmente, a través da colocação de anüncios e cartazes das mais variadas formas, nos mais diversos locais da cidade, além dos problemas de segurança aos transeuntes que podem acarretar, contribuem bastante para a chamada poluiçăo visual urbana.

Areas de grande valor ecológico ou paisagístico são gradativamente ocupadas, transformando locais de muita beleza em densas äreas urbanas. Entre estas äreas podemos citar as dú nas, as encostas de morros e as märgens de coleçöes superfici ais de àgua.

Alèm dos e eitos negativos, sob o ponto de vista eco lögico, este processo de ocupaçäo desordenada é responsävel pe la carencia de paisagens que proporcionem ao homem das cidades um bem-estar mental e social, proprios do lazer contemplativo.

Todos estes aspectos da poluição visual, embora de caräter bastante subjetivo, vêm sendo levantados ultimamenta, e a sua ocorrência, aliada a outros tifos de degradação ambien tal, é apontada como causa de tensões, angüstias e efeitos cor relatos sobre o homem urbano.

E necessärio, portanto, considerar estes aspectos no disciplinamento do uso do solo urbano. A ocupaçäo urbana deve ser feita de forma a se integrar, omäximo possível, às condi çöes naturais existentes, principalmente onde áreas de valor estëtico devam ser preservadas. 
5. USO DO SOLO E PRESERVAÇÃO 00 HE 10 AMBIENTE

Nos capítulos anteriores tentamos mostrar como o pro cesso de urbanizaçäo; alterando as características naturais de determinada ärea, pode resultar em modificaçōes ambientais das mais variadas formas, constituindo diferentes modalidades de po lui çāo.

A transformação de um ambiente rural para um meio urbano por certo sempre resultarä em alteraçöes ambientais, com reflexos sobre as formas de vida que normalmente abriga. Compe te ao homem procurar adequar o processo de urbanização ao ambi ente físico existente, de modo que os efeitos negativos sejam os mínimos possíveis. Entendemos que um planejamento urbano que considere os aspectos ambientais pode minorar estas consequênci as.

Atualmente, o homem dispõe de técnicas de planejamen to urbano que vêm sendo aplicadas nas cidades, considerando os aspectos sociais, culturais e económicos, mas pouco se preocu pando com os fatores ambientais.

A notureza tem uma grande capacidade de recuperaçäo, quando alterada em uma de suas características. Os recursos na turais podem ser usados pelo homem como fonte de ar, ägua, ali mento, energia e matēria prima para suas atividades, bem como meio de absorçãc, dispersajo ou transformação de seus resíduos.

porém, esta capacidade é limitada, devendo o homem conhecē-la e a ela adaptar-se. Os processos naturais devem ser levados em conta no planejamento de uma àrea urbana.

Desta forma, o aspecto ambiental è mais um fator a ser considerado no planejamento urbano.

Muitos sajo os princípios de saneamento que devem ser aplicados ao planejamento urbano. D disciplinamento do uso do solo urbano feito com base nestes princípios, com certeza pro porcionara um meio ambiente urbano melhor, sem muitos dos pro blemas de poluição comentados anteriormente.

o importante é que a utilização destes princípios constitua uma forma preventiva de controle da poluição, portan to, mais fäcil de aplicar e, acreditamos, de maior eficiência.

Tentaremos mostrar como o disciplinamento do uso do solo pode ser feito considerando princípios bāsicos de saneamen 
to, utilizando medidas de prevençāo contra a poluição do solo, do ar, da ägua, acüstica e visual.

Serão desenvolvidas algumas técnicas a serém aplica das no processo de disciplinamento do uso do solo urbano, como objetivo de preservar os recursos naturais indispensáveis às äreas urbanas.

A utilizoção destos técnicas poderá ser feita de duas maneiras: estudando detalhedamente cada recurso ratural, de forma que as medidas de preservaçäo a serem adotadas sejam função das caractertsticas proprias do mesmo; ou adotando medi das preventivas prémfixadas, com base nos conceltos jä estabele cidos, de um modo gerali como välidos.

Por exemplo, a preservaçäo de um recurso hídrico su perflcial poderä ser folta atraves de uma falxa sanitäria de proteção, a qual terá largura variäyel, em funçäo do levantamen to das características prōprias deste meio e de suas márgens, quando for possível determinä-las. ro entanto, poderá ser esta belecida uma faixa de largura fixa, a partir de conhecimentos jā existentes sobre a percolaçāo te poluentes no solo.

E claro que o primeiro caso deverä apresentar resul tados mais satisfatórios, pois estudará cada recurso detalhada mente. o controle da poluiçäo do meio ambiente é mais eficiente quando feito a luz das circunstancias locais. Devemos, porém, re conhecer que poucas cidades brasileiras dispōem de condiçós pa ra realizar, no momento, levartamentos detalhados dos recursos naturais a preservar. Assim, muitas medidas de preservação de vem ser adotadas de forma generalizada, a partir de eritérios já conhecidos e admitidos come corretos.

Tentaremos indicar os procedimentos a serem uriliza dos para estudo de determinado recurso, visando a sua preserva ção, e procuraremos discutir algumas medidas que poderāo ser a dotadas de modo gerol, no processo de disciplinamento do uso do solo visando a qualidade ambiental.

Inicialmente, comentaremos alguns conceitos bäsicos relacionados com o planejamento urbano. Posteriormente, mostra remos como interrelacionar o flanejamento como o saneamento am biental, de modo a controlar, de forma preventiva, as diversas modalidades de poluição. 
5. 1 - Técnicas de Planejamento Urbaho

"O planejamento urbano consiste ná organizaçăo do es paço das atividades e funçōes de uma cidadej levando én cons $\mathbf{i}$ deraçăa a realidade existente e suas implicaçoés no desenvolvi mento futuro, não só do ponto de vista físico, como támbém so cial e económico, para obter o bemintestar progressivo desta lo calidade". (15)

o planejamento urbano yisa, portanto, a ordenaçāo do espaço físico e a provisäo dos elementos relativos às necessida des humanas, de modo a garantir úm meio ambiente que proporcio ne uma qualidade de vida indispensável a seus habitantes.

De acordo com a Associaçōo Internacional de Adminis tradores Municipais (27), o processo de planejamento compreende cinco etapas:

- estabelecimento de metas bäsicas

- estudos e anälises

- preparação de planos e políticas

- implantação de planos e políticas

- avaliação

Ainda de acorto com a citada Associação, as princi pais ferramentas do planejamento urbano são:

(a) o plano geral, incluindo os objetivos e politi cas básicas do desenvolvimento, o levantamento de dados e os estudos bäsicos necessärlos ao pla no

(b) o zoneamento, compreendendo a definição de usos para as diversas äreas da cídade

(c) o regulamento de loteamentos, definindo normas para o parcelamento de terrenos

(d) programa de aplicação de capital (recursos finan ceiros)

o zoneamento é o dispositivo legal mais simples para a implantaçäo do plano de uso do solo de uma cidade. Através do mesmo pode-se assegurar que os diferentes usos do solo serāo a dequadamente distribuídos em uma ärea urbana, de modo a garan tir às pessoas a realizaçāo plena de suas necessidades de habi 
tação, trabalho, circulaçāo e lazer.

Através do zoneamento, a ärea planejada é dividida em setores, para os quais săo definlís: (1) a altura e volume dos predios e de outras estruturas; (2) as áreas dos lotes e as porçỏes dos mesmos que podem ser ocupadas; (3) a densidade pop $\underline{u}$ lacional; (4) os espaços livres requeridos; (5) o uso do solo e das edificaçōes por atividades comerciais, residenciais, indus triais e outras.

Para implantaçäo do processo de zoneamento, além da definicäo dos usos permitidos, tolerados ou proibidos para as diversas äreas da ciciade, são fixados parâmetros que garantam a ocupação do solo na forma jesejada.

Estes parámetros são conhecilos como TNDICES URBANTS TICOS, os quais são expressões matemäticas que relacionam o es paço com grandezas söcio-económicas ou físicas.

Assim, os indices urbanisticos refletem a situação sōcio-ecnómica de uma unidade territorial ja implentada ou PQ dem servir como meio disciplinador da ocufaçäo desejada para uma àrea ainda não desenvolvida.

Desta forma, estes índices podem ser usados nas di versas fases do planejamento, sencio aplicados na anälise da rea lidade urbana, na formulaçāo de prognósticos e proposiçōes, bem como na etapa de regulamentação e controle.

os indices urbanifsticos são definidos pela Assocla çäo Brasileira de flormas Técnicas, através da TB-150, de 1977, sendo representados por três tipos rundamentais de expressão: DENSIDADE, QUOTA E PROPORÇÃO.

A Densidade exprime uma ralaçāo entre elementos físi cos ou atividades e um indicador de aspaço. Como elementos físi cos ou atividades, podemos entender: pessoas, animais, produtos agrícolas, ccorrência de doenças, empregos, etc.

A densidade populacional è um exemplo deste indice e normalmente expressa o grau de concentração ou dispersão de pes soas em determinadas äreas. Estả bastante relacionada com o di mensionamento de equipamentos sociais a de serviços públicos.

De um modo geral. temos dols tipos de densidade resi dencial:

(1) Densidade residencial bruta: expressa uma rela çăo entre a população considerada (de uma cidade 
bairro ou setor) e a ärea total da cidade, bair ro ou setor

(2) Densidade residencial líquida: relação entre a população de uma cidade, bairro ou setor e a á rea ocupada por residencicias.

Normalmente, devido a maior facilidade de aplicação, usam-se formas indiretas de expressão da densidade populacio Hal. Pc exemplo. é comum usar-se a densidade "habitaçōes por unidade de àreall pois hả uma correlaçāo bastente estreita entre a populaçāo e o número de domicílios.

outros exemplos de Densidade podem ser citados: nüme ro de empregados/área ocupada pela atividade dos mesmos; número de empregados na industria/m de área construída.

A Quota é um indice urbanístico mais facilmente ass? ciävel às idéias de ocupação ou demanda de espaço, pois é ex presso por uma relação entre um indicador de espaço e um indica dor de elementos físicos ou atividades:

Podem ser citados como exemplos de Quotas:

$\mathrm{m}^{2}$ ou hectare de terreno/habltante ou habitaço

$\mathrm{m}^{2}$ ou hectare de ärea construída/habitante ou habita ção

ärea de terrenolou construída)/n? de empregados

ärea livre/população ou número de domicílios

quilómetros de ruas/hacitantes

As Quotas figuram na regulamentaço e controle do uso e ocupação do solo urbano. Frequentemente, encontramos, em legislaçōes urbanísticas, a derinição de tamanhos mínimos de lo tes, o que pode ser entendido como uma quota - area de terrenol tipo de habitaçāo - a qual, indiretamente, regulamenta a densi dade residencial.

As Proporfões sẽo indices urbanísticos que relacio nam dois espaços, sencio normalmente expressos por um nümero pú ro ou sob a forma de porcentagem.

As proporçōes são muito utilizadas na regulamentação e controle de loteamentos, sob as mais variadas formos: porcen tagem de áreas livres; porcentagem de äreas para escolas e ou tros equipamentos públicos; porcentagem de ocupaçāo dos lotes 
por construçōes, etc.

A intensidade de ocupação física dos terrenos pelas construçōes è expressa atravēs de três proporções bastante ut lizadas em legislaçōes de disciplinamento de uso e ocupaçāo do solo:

- coeficiente de aproveitamento

- taxa de ocupação dos terrenos

- indice de elevação

o coeficiente de aproveitamento è o que melhor reve la a intensidade de uso, pois $\vec{e}$ a relaçäo entre a ärea total construída e a àrea total do terreno.

A taxa de ocupacão dos terrenos expressa as äreas li vres sobre o terreno, sendo um indicador das condiçoes de ilu minaçāo, insolação, ventilação e isolamento das edificações. E a razão entre a área ocupada pela construção e a ärea total do terreno considerado.

o indice de elevação, que exprime a relação entre a àrea total construída e a ārea ocupada pela construçāo, dá uma idéia do número médio de pavimentos.

os indices urbanísticos, já bastante utilizados em legislaçōes urbanísticas, podem ter sua aplicaçäo ampliada, vi sando a preservação do meio amíiente. Constituem importante fer ramenta de planejadores e sanitaristas, no disciplinamento do uso do solo para uma malhor qualidade de vida urbana.

Alguns exemplos de sua arlicação podem ser citados:

- Definiçāo de densidades demogräficas compativeis com a infra-estrutura sanitária existente ou proje tada

- Areas mínimas dos lotes estabelecidas em função do existência ou näo de sistemas püblicos de água e esgoto

- Estabelecimento de áreas livres visando a preserva ção de márgens de cursos d'ägua, de äreas de recar ga de aquíferos ou como faixas de isolamento de fontes poluidoras do ar cu acústica

- Definição de índices de ocupação com o objetivo de permitir maior ärea livre para a recarga de aquífe ros, redução do escoamento superficial e da ero 
săo, ou como medida de controle da poluição da á gua superficinl

- Indice de elevação (altura das edificaçōes) defini dos em determinadas äreas para garantir a ventila ção ou proporcionar a visão de uma paisagem bon ta.

Estes são alguns exemplos do utilização de indlces urbanisticos visando a preservação do meio ambiente. No decor rer do trabalho, estes e outros casos serão discutidos e deta Ihados.

De um modo geral, podemos estabelecer que o planeja mento de uma ärea urbana, com o objetivo de preservar a qualida de do meio ambiente, deve ser feito em seis importantes etapas:

(1) Levantamento das condiçōes ambientais existen tes, a partir do qual se desenvolverá o planeja mento

(2) Definição das áreas apropriadas para uso urbano e, consequentemente, das äreas a serem preserva das

(3) Definição dos diferentes usos do solo urbano, em função do maior ou menor impacto que os mesmos possam causar ao ambiente

(4) Utilizaçoo de ondices urbanísticos que permitam uma ocupacão das uiferentes zonas da cidade, de forma a garantir uma melhor integraçăo das edifi caçōes e de outras estruturas com o ambiente ne tural

(5) Definição de padröes de qualidade ambiental, em funçāo das circunstâncias específicas de cada am biente, devendo as medidas de controle de polui ção serem aplicadas para alcançarem aqueles obje tivos

(6) Relacionamento dos aspectos de preservação amb ental com os outros fatores a serem considerados no planejamento urbano, de modo a garantir um processo exequível sob o ponto de vista econômi co, social e politico.

De modo integrodo devem ser planejados os diversos 
aspectos de controle da poluição, em suas diversas modalidades: do solo, do ar, da água, acústica e visual.

Por questōes didäticas, abordaremos, a seguir, de for ma isolada, o relacionamento entre o disciplinamento do uso do solo e o controle de cada forma de poluigão, porém, sempre pro curando ressaltar a sua ligaça com as outras modalidades.

5.2 - Uso do solo e controle de poluição do solo

o solo não é, normalmente, um meio a partir do qual um poluente é transferido diretamente para o homem, como aconte ce com a ägua e o ar.

Embora ocorra o contato das pessoas com os resíduos lançados no solo, o mais frequênte é acontecer, a partir do pro cesso de poluição do solo, alteraçōes na qualidade de outros ré cursos naturais, de modo a prejudicar o homem.

Das principais causas da poiuiçäo do solo enumeradas no item 4.3.1, podem ser consideradas de maior importancia, do ponto de vista do planejamento urbano, o larçamento de resíduos sölidos ou líquidos nos terrenos e as atividades provocadoras da erosão do solo.

Na realidade, a ocorrencia desta modalldade de polui çāo e, em consequência, da degradação de outros recursos natú rais, pode ser controlado atraves do disciplinamento do uso e ocupação do solo urbano.

Conforme mostraremos a seguir, a adoção de medidas de preservação do meio ambiente, consideradas no processo de planejamento do uso do solo urbano, contribui para minimizar os efeitos da disposição de resíduos no solo, bem como para atenu ar a erosão, geralmente acentuada em àreas urbanas em desenvol vimento.

5.2.1 - Disposiçāo de resíduos no solo

A prática de lançar resíduos líquidos, sólidos ou se mi-sólidos no solo, pode resultar em iroblemas de degradação am biental, quando nāo executada considerando aspectos sanitärios. 
A maioria das cidades brasileiras ainda utiliza a forma de dar destino aos resíduos sölidos através de depósitos a cẻu aberto. os efeitos negativos deste sistema de disposição final do 1 ixo já foram comentados anteriormante.

Portanto, partimos do principio de que este procosso deve ser proibido e nos restringlremos a indicar as medidas de preservaça ambiental a serem adotadas quando forem usados méto dos sanitärios de utilizaça do solo para receuimento de residu os. Mais precisamente, abordaremos diversos aspectos relacionan do o aterro sanitärio com o meio amblented

Mesmo em pequenas comunidades, o lançamento de lixo em depósitos a cëu aberto deve ser evitado. Nestes casos; o li xo deve ser enterrado atravës de processo manual, podendo cons tituir um pequeno aterro sanitärio, desde que sejam adotados os diversos cuidados para preservor a qualidade ambiental.

Com relação a disposição de residuos líquidos ou se mi-sölidos (lodos) no solo, também nos referimos aos princípios a serem adotados na execução de práticas consideradas sanitári as.

As consequências do lançomento de resíduos no solo estāo bastante relacionadas com o ambiente que o cercáA partir dos resíduos colocados no terreno podem originar-se líquidos de percolaçāo, os quais atingirāo coleçōes superficiais ou subter ráneas de àgua. Existem ainda os problemss relacionados com o aspecto estético (poluição visual) e com os maus odores.

Uma maior ou menor degradação do meio ambiente, alèm das características dos resíduos lançados no solo,dependera das condiçōes do pröprio ambiente, as quais precisam ser estudadas antes da escolha do local para recebimento dos mesmos.

Assim, na definição de locais para lançamento de re siduos no solo, devem ser previamente analisados os seguintes aspectos, relacionados com o ambiente em estudo:

- GEOLÓGICOS

- HIDRO-GEOLOGICOS

- topográticos

- climaticos

- culturaIs

- eCONOMICOS

A definição do local será o resultado de uma anălise 
global de todos estes aspectos, conforme indicado no esquema da FIgura 5.1. Obviamente, não importa a órdem de avaliaçäo dos di versos aspectos, sencio a que esta apresentada na figura apenas ilustrativa.

Uma anälise do ponto de vista GEOLOGICO deve identi ficar as formaçōes geolägicas que se situarão em baixo e ao la do do local de disposiçäo dos resíduos, bem como o tipo de so lo para cobertura dos mesmos, se for o caso. Intercssam mais, nesta circunstancia, as propriedades do solo relacionadas como movimento de líquidos e gases em seu interior.

Sob o aspecto HIORO-GEOLOGlco, devem ser analisadas as coleçōes superficiais e subterrāneas de ägua e todos os fato res relacionados com as mesmas: nível do lençol freático; varia ções de níveis; movimento da ägua superficial ou subterrānea; äreas de carga e descarga de àgua superficial ou subterrânea.

As condições TOPOGRÁFICAS a serem consideradas são as que dizem respeito ao maior ou menor movimento de terra, bem como ao ingresso de líquidos na ärea utilizada. Áreas sujeitas a inundaçōes devem ser evitadas, assim como acjuelas com grande potencial de erosão.

Quanto aos aspectos CLIIIÁTICOS, interessam: direção e velocidade dos ventos; temperatura; precipitaçäo pluviométri ca; evaporaçāo.

Do ponto de vista ECOLOGICO devem ser cuidadosamente analisadas as äreas que constituem ecossistemas importantes pa ra a preseivaçäo da fauna e da flora, com o objetivo de evitar a ocorrência de desequilibrios e, consequentemente, os seus e feitos sobre espécies.animais e vegetais.

Do ponto de vista CULTURAL devem ser observados os aspectos relativos à estētica visual, às implicaçōes em termos de uso do solo nas proximidades, e à aceitação por parte do pü blico.

Sob o ponto de vista ECONOAICO seräo analisados: cus to do terreno; despesas para implantaça do sistema; desvalori zaçäo de äreas vizinhas, entre outros. 


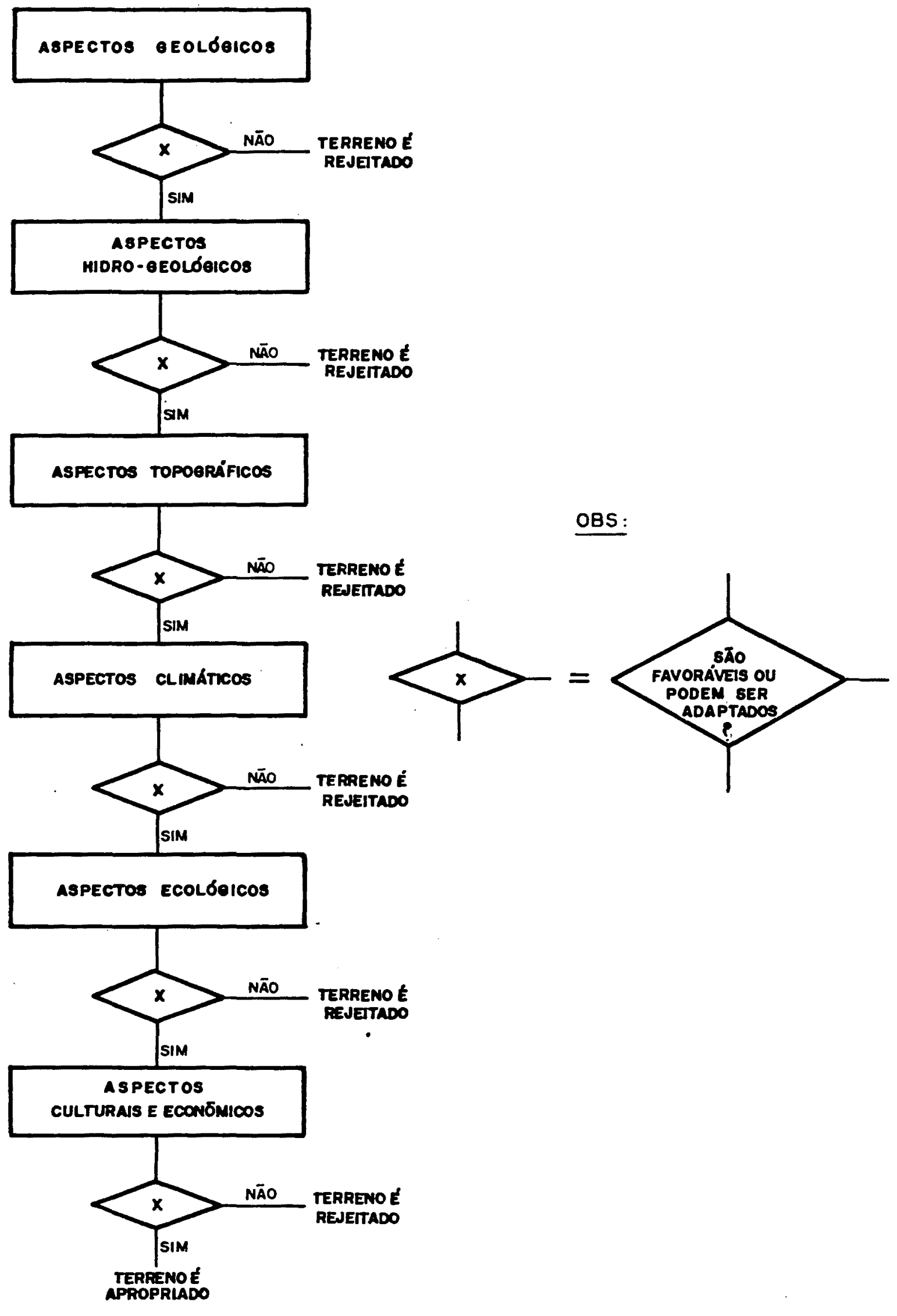

FIOURA 5.1

MODELO DE AMÁLISE DOS ASPECTOS AMBIENTAIS MA

EBCOLHA DE TERRENO PARA RECEBER RESIDUOS. 
5.2.1.1 - Disposiçäo de resíduos sölidos

Com base nesta sistemática global de anälise,vejamos as aspectos a serem considerados na escolha de um local para um aterro sanitärio.

Entre os probiemas ambientais que podem resulter de um aterro sanitärio, destaca-se a poluiçáo dos recursos hidri cos superficiais ou subterrāneos. Isto pode acontecer através de uma das seguintes formas:

- Pelo carreamento de materiais do aterro para cole çōes superficiais de àgua

- Pela invasão de äguas superficiais sobre jreas do aterro

- Quando a ägua do lençol freätico atinge os resídu os

- Pela percolação vertical do "liquido de percola ção" ("leachate") formado no aterro e resultante de àquas de chuvas, da pröpria umidade dos resídu os e dos produtos da decomposição dos mesmos

- Pela transferencia de gases resultantes da decompo sição de resíduos e que sāo solüveis na ägua

A poluição da ảgua a partir de um aterro sanitário dependerá, portanto, dé:

(1) dos tipos de materiais constituintes dos resídu os sölitos, os quais caracterizarāo a composiçāo dos poluentes

(2) das características do meio onde se situa o ater ro, as quais vão influir no deslocamento dos po luentes originados no aterro

(3) do posicionamento do aterro em reiação aos recur sos hídricos subterrāneos e superficiais

(4) Je falhas no elaboração do projeto e execução do aterro.

A anälise e controle destes fatores constituem as ferramentas básicas para evitar os impactos ambientais resultan tes de um aterro sanitärio.

A composição do "líquido de percolação" e, portanto, 
o seu potencial poluidor dependerā dos tipos de materiais depo sitados no aterro e das reaçōes que se processam na decomposi ção dos mesmos.

Estes poluentes podem ser biolögicos ou químicos. Em condições normais a poluição biolójica é que menos problemas po de trazer, devido à pouca capacidade de sobrevivéncia dos orga nismos patogênicos e a relativa pouca distância que normalmente percorrem; a poluição química, principalmente devida a certos residuos sólidos provenientes de indüstrias ou resífuos de sua incineração, é que pode criar mais problemas. (16)

A produção de "liquido de percolação" a partir de re síduos sölidos municipais vem sendo estudada através de pesqui sas de laboratōrio e de campo, observando-se que a composiçāo do mesmo varia com o local da produção e com o tempo. No QUADRO 5.1 mostramos a composição do "leachate" inicial resultante de residuos sälidos municipais, dados obtidos em dois estudos efe tuados nos Estados Unidos da América e apresentados por BRUNNER e KELLER.

Observando O QUAARO 5.1 podemos notar uma grande va riaçäo de valores. Os autores do trabalho comentam, também, que hä uma variação do "líquido percolado" com o decorrer do tempo, para um determinado aterro, bem como entre os dois aterros. Ci tam, como exemplo, a concentração de sulfatos, a qual, no Estü do $A$ apresentou uma média de $614 \mathrm{mg} / 1$, mudando de $730 \mathrm{mg} / 1$, no início da amostragem, para $81 \mathrm{mg} / 1$, próximo à conclusäo do levan tamento. Não hä indicaçăo do período durante o qual se realiza ram os estudos. No entanto, o trabalho observa que se pode espe rar um decréscimo na quantidade de contaminantes com o tempo. em aterros onde não são mais depositados resíduos.

o movimento do "leachate" no solo ocorre verticalmen te, na zona não saturada, e de acordo com o fluxo da água sub terrānea, na zona saturada. A "purificaçäl deste líquido na zo na näo saturada é maior do que na zona saturada, conforme jä visto anteriormente.

A remoção de poluentes orgânicos e bacteriolögicos é ouservada em percursos relativamente pequenos, enquanto que com postos inorgânicos podem alcançar grandes distâncias. 


\section{QUADRO 5.1}

Composicão de líquidos percolados em resíduos sölidos. Estados Unidos da América. (Dados em ppm,exceto o pH)

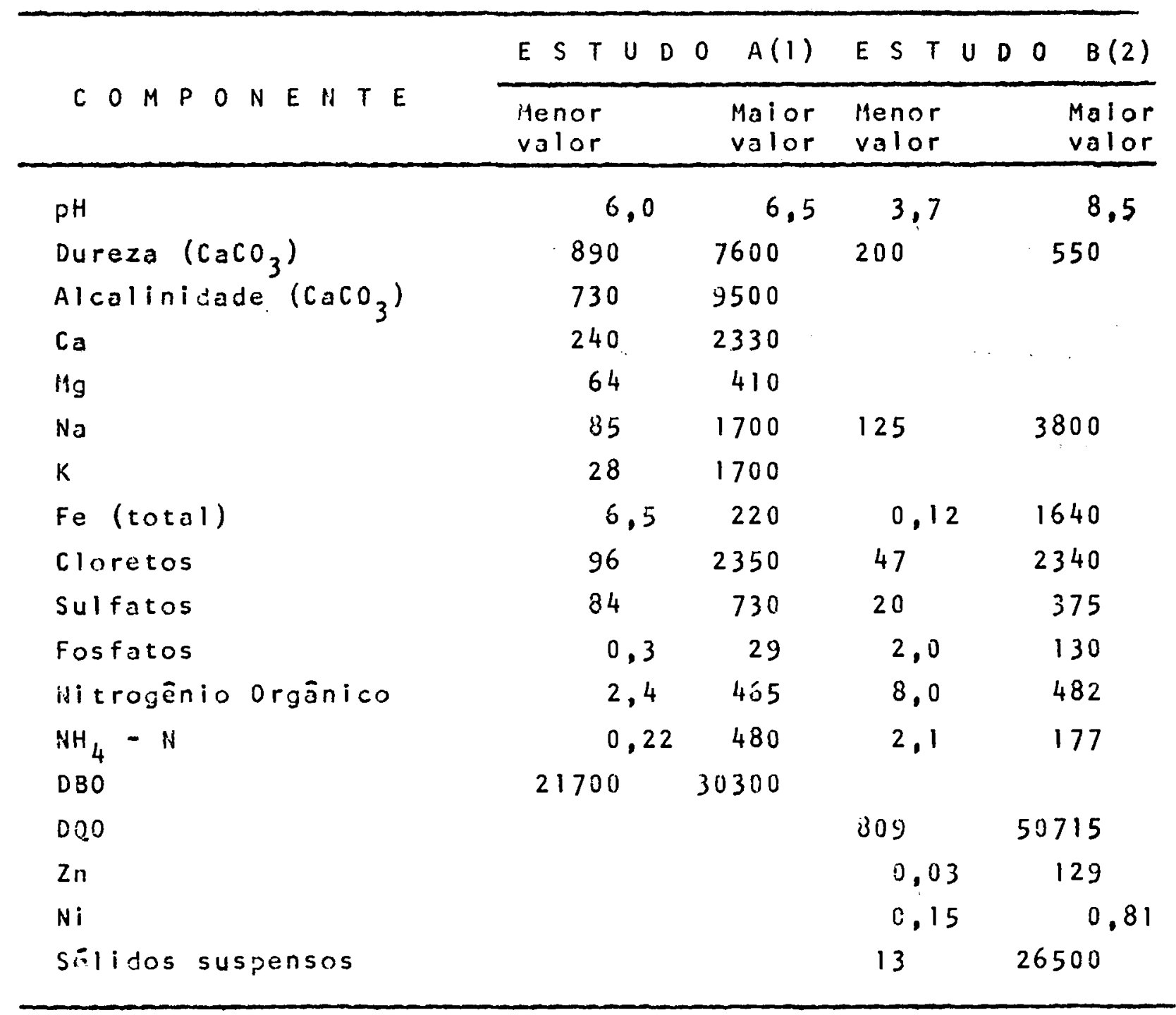

FONTE: BRUNNER, D.R. \& KELLER, D.J. 1972 (12)

Obs: (1) California State Pollution Control Board

(2) A.A. Fugaroli - "pollution of subsurface water by sanitary landfill". 
Compostos químicos pojem percolar através do solo por longo tempo e alcançando grandes distâncias, conforme comen tado no ítem 4.3.3.2.2.

Estudos que realizamos junto ao aterro sanitário de Fortaleza, em 1973, apresentam alguns dados relativos à polui ção da ägua subterrânea a partir de resíduos sölidos municipais depositados no solo:

Para este éstudo foram perfurados 4 poços, sendo 1 a montante da área aterrada e 3 a jusante. Comparando a análise da ägua obtida no primeíro poço a jusante, situado n 15 metros do aterroj com. a jo ṕoço de montente, podem ser observadas ele vações dos teores de turbidez, cor, dureza, magnésioj condutivi dade espectfica, amônia e oxiģânio consumido. Porëm, somente o teor de oxigènio consumido ficou acima do padräo recomendado pe la Associaçāo Brasileira de Normas Técnicas. A ägua deste poço a Jusante apresentou odor sulfítrico e foi considerado não pota vel, do ponto de vista químico e bacteriológico.

Dos outros dois poços a jusante, situados a 45 e 75 metros do aterro, foram captadas äguas potäveis, do ponto de vista químico e bacteriolögico.

Na época desta pesquisa, o nivel do lençol freático estava a cerca de 2 metros abaixo do fundo do aterro.

Este trabalho mostra que hä ralmente uma remoça de poluentes do líquido, quando o mesmo percola no solo. Como os residuos eram de origem municipal, a purificaça do "leachate"foi obtida em menos de 45 metros de percurso.

Como jà dissemos, esta remoção de poluentes depende das condiçöes do meio onde se localiza o aterro.

Alëm do tipo de contaminante, um maior ou menor al cance do mesmo depende das características do solo e das condi çōes hidro-geolögicas, topogräficas e climäticas.

A permeabilidade do solo influi no movimento do li quido atravès do mesmo, sendo este favorecido em terrenos com maior coeficiente de permeabilidade. Assim, não se recomenda a execução de aterros sanitärios sobre solos com alta permeabili dade, a não sar que medidas protetoras, tais como a impermeabi lização do fundo, sejam adotadas.

E importante, tambēm, saber-se se nāo existem fratú ras em rochas consolidadas, sob a ārea de disposiçäo dos resídu os. Atravēs de fendas, os poluentes podem alcançar lençōis d'ä 
gua profundos:

As caracteristicas do solo a ser usado como material de cobertura dos resíduos säo importantes, pois, dependendo do do tipo do mesmo, pode ser favorecida ou näo a penetraçäo e per colaçăo de ifquidos. Alguns aspectos devem ser considerados na escolha do solo para esta finalidade. No QUÁDRO 5.2, transcreve mos de (12) uma avaliação de diversos tipos de solo, em função das värias funçōes do mesmo como material de cobertura.

SENGES recomenda como materail para cobertura de a terros sanitärios uma mistura de araia e argila - solo arenoargiloso. (45)

A hidrologia da ärea a ser utilizada para um aterro sanitärio deve ser conheclda, para se saber se o líquido perco lado no aterro se constituirá um perigo de poluição das äguas. os aspectos a serem analisados săo: localização a movimento da àgua subterrānea; escoamento da àgua superficial; existência de coleçōes superficiais de ägua e niveis mäximos de inundação.

A precipitaçāo pluviométrica e a evapo-transpiraçäosäo aspectos que devem ser conhecidos, pols têm influēncia so bre a quantidade de água que se infiltra no aterro para a forma çäo do "leachate".

Como vemos, o estudo de uma ārea para aterro sanitä rio compreende a avalieçao de värios aspectos ambientais. Deve mos observar, no entanto, que as informaçōes existentes sảo pou cas e nem sempre os municipios dispõem de condiçōes para efetua rem todos estes levantamentos. Assim, usa-se como principal meio para preservar o meio ambienta o posicionamento do aterro em relação à ärea urbana.

Este posicionamento deve considerar princífios de sa neamento jä conhecidos. Com relação aos recursos hídricos super ficiais e subterrâneos, a medida preventiva indicada è a edoçāo de distâncias minimas entre a ärea de recebimento dos resíduose estas coleçōes de ägua. E obvio que estas distäncias variam em funçāo das características do meio. Porèm, existem valores jä recomendados, emfunçāo da capacidade de remoção de poluentes no solo, tanto em zonas näo saturadas como em zonas de satura çāo.

Para preservar a qualidade da àgua do lençol freáti co, säo aconselhadas distancias mínimas entre o nível mäximo do 
QUADRO 5.2

Seleçāo de material de cobertura final de aterros sanitärios, para as diversas finalidades da mesma

\begin{tabular}{|c|c|c|c|c|c|c|}
\hline $\begin{array}{l}\text { MATERIAL } \\
\text { FUHÇOEES }\end{array}$ & $\begin{array}{l}\text { Cascalho } \\
\text { Limpo }\end{array}$ & $\begin{array}{l}\text { Cascalho } \\
\text { c/aluvi- } \\
\text { ao e ar- } \\
\text { gila }\end{array}$ & $\begin{array}{l}\text { Areia } \\
\text { Limpa }\end{array}$ & $\begin{array}{l}\text { Argila } \\
\text { c/alu- } \\
\text { vião }\end{array}$ & Aluvião & $\begin{array}{l}\text { Argi- } \\
\text { la }\end{array}$ \\
\hline $\begin{array}{l}\text { Prevenção contra o } \\
\text { acesso de roedores }\end{array}$ & $B$ & $A-B$ & $B$ & $M$ & $M$ & $M$ \\
\hline $\begin{array}{l}\text { Prevenção contra } \\
\text { moscas }\end{array}$ & 11 & $R$ & $H$ & B & B & $E+$ \\
\hline $\begin{array}{l}\text { Redução da entrada } \\
\text { de ägua no aterro }\end{array}$ & $M$ & $A-B$ & $M$ & $B-E$ & $B-E$ & $E+$ \\
\hline $\begin{array}{l}\text { Redução da saída- } \\
\text { de ägua atraves do } \\
\text { material de cober- } \\
\text { tura }\end{array}$ & $n$ & $A-B$ & $M$ & $B-E$ & $B-E$ & $E+$ \\
\hline $\begin{array}{l}\text { Melhoria do acaba } \\
\text { mento e aparéncia } \\
\text { do aterro, e pre } \\
\text { venção da dispér } \\
\text { são de papēis }\end{array}$ & $E$ & $E$ & $E$ & $E$ & $E$ & $E$ \\
\hline $\begin{array}{l}\text { Suportar bem o cres } \\
\text { cimento da vegeta- } \\
\text { çäo }\end{array}$ & $\mu i$ & B & $M-A$ & $\mathbf{E}$ & $B-E$ & $A-B$ \\
\hline $\begin{array}{l}\text { Permitir a venti- } \\
\text { lagáo dos gases - } \\
\text { produzidos pela - } \\
\text { decomposiça dos - } \\
\text { resíduos +t }\end{array}$ & $E$ & $M$ & B & $M$ & $M$ & $M$ \\
\hline
\end{tabular}

FONTE: BRUNAER, D.R. E KELLER, D.J. 1972 (12)

E - excelente; B - bom; A - aceitável; $M$ - mau

+ com excessão dos locais onde o materiol está sujeito a contrações excessivas e consequénte aparecimento de fendas

++ somente em conjunto com boas condiçöes de drenagem 
mesmo e o fundo do aterro, variando de $1,50 \mathrm{~m}$ a $3,00 \mathrm{~m}$.

Para a preservação das coleçōes superficlais de ăgua é recomendado um afastamento das mesmas variando de $30 \mathrm{~m}$ a $45 \mathrm{~m}$,no mínimo, distáncia considerada satisfatōria para a remoção de poleuntes orgánicos e biolögícos de líquidos percolando horizon talmente no solod

Esta medida de posicionar o aterro levahdo em consi deração a poluição da àgua è muito vālida quando năo se conhé cem detalhadamente os aspectos ambientais do meio. Nestes ca sos, deve-se afastar o mäximo possível o depósito de resíduos das coleções superficiais de ägua, para minimizar as possibili dades de poluição.

Temos que considerar, nestas situaçōes, o aspecto de impacto sobre o população. A execução de aterros próximos a co leçōes de àgua, mesmo a distâncias sanitariamente seguras, pode não ser bem aceita pelo püblico.

Existe ainda o escomento superficial da água e o vento, que podem carrear materiais do aterro para coleçōes de ägua, devido à proximidade.

Por outro lado, a execuçāo dos servicos no aterro e xige áreas para circulação dos equipamentos, acūmulo de materi ais, isolamentos, etc.

Em vista de-todas estas consideraçōes, quando não for possível um exame detalhado do local, recomenda-se a adoção de afastamento de, no mínimo, 300 metros do limite do aterro pa ra o nível mäximo de coleções superficiais de āgua.

Nos casos de aterros sanitärios em que são depositä dos resíduos sölidos de procedencia industrial, onde diferentes compostos químicos podem estar presentes, o alcance do "leacha te" é bem maior, conforme jä comentado. Näo se pode prever, sem que estudos mais aprimorados sejam desenvolvidos, as distancias mäximas de alcance dos poluentes. Recomenda-se, portanto, a exe cução destes aterros somente após estudo detalhado do ambiente, sugerindo-se a localização dos mesmos em āreas distando mais que $i .000$ metros da zona urbanizada e de coleções superficiais de āgua.

Em todos os casos, alëm das providências com relação ao afastamento, outras medidas de controle, ou de adaptação do local, podem ser adotadas, tais como: dasvio das águas de escoa 
mento, atravēs da execução de vailetas em torno do local; colocá ção de drenos para escopamento dos gases; impermeabilização, ou reduçāo da infiltração das paredes laterais e do fundo; captação e tratamento do líquido percolado.

Alèm do perigo de poiuição da ägua, outros aspectos ambientais devem ser analisados quando da definição de áreas pạ rá aterros sànitärioś

- Poluição visual, sempre presente em trabolhos com resíduos sölidos

- Produção de ruídos, pela movimentação dos equipa mentos

- Incómodos causados pela circulação de veículos no acesso à àrea

- Alguns maus odores que possam, eventualmente, exis tir

- A desvalorização jos terrenos situados nas proximi dades

o mäximo rigor adotado na execução de um aterro sani tärio nāo impedirá que estes efeitos ocorram. os mesmos podem ser atenuados procurando-se definir uma localização adequada pa ra.o aterro, em relação à ảrea urbana.

o local do aterro não deve ficar pröximo às āreas zo neadas como de uso residencial ou recreacional. Mesmo em rela ção a outras zonas, deve-se scmpre prever na ärea total destina da ao aterro faixas de isolamentos.

Para disfarçar a poluição visual, podem-se aprovei tar desniveis topogräficos, uma vegetação intensa ou construir barreiras artificiais de isolamento. A distância é sempre o me Ihor fator de atenuação dos efeitos negativos de um aterro sani tärio.

o acesso à ärea do aterro deve ser planejado de for ma a facilitar a circulaçäo dos veículos, não se recomendando,em cidades de grande porte, intenso movimento em ruas de uso re sidencial.

o controle de maus odores que possam existir, eventü almente, pode ser feito posicionando-se o aterro no sentido con trärio aos ventos predominantes, em relação à àrea urbanizada. Desde que haja uma preocupação con as consequéncias de um aterro sanitārio, em termos de qualidade ambiental, o mes 
mo pode ser executado sem grandes problemas. No entanto, todas estas questöes devem ser levantadas na fase de planejamento "do aterro, jä que as meuidas corretivas nem sempre produzirāo os efeitos desejados. E isto deve fazer parte do planejamento da cidade como um todo, jä que muitos aspectos estão envolvidos.

5.2.1.2 - Disposiçäo de resíduos líquidos

A utilização de terrenos como meio receptor de resí duos líquidos è feita; normalmente, através de umo das seguin tes präticas:

- Como melo de infiltraçáo de efluentes de sistemas de tratamento tipo fossa sëptíca

- Em processos de tratamento de esgoto, tais como la goas de estabilização

- Em präticas de irrigação, usando efluentes de sís temas de tratamento de esgoto

o primeiro mëtodo estä bostante relacionado com a po luigäo do lençol freātico, e serä estudado posteriormente, quan do nos referimos ao controle da poluiça da ägua.

o uso de esgoto tratado para irrigação somente deve ser feito em äreas determinadas, sob controle. E uma prảica que vem sendo usada com sucesso, mas acompanhada de medidas es pecificas de controle, visondo utilizar líquidos submatidos a tratamentos eficientes, para não causar danos so meio ambiente.

As lagoas de estabilização são utilizadas, atualmen te, para tratamento de esgotos domésticos e industriais. Na anä lise dos impactos ambientais deste sistema, podem ser utiliza dos os parâmetros indicados no caso do aterro sanitärio, já que as consequências sobre o meio ambiente säo semelhantes:

- Possibilidade de poluição da ägua, a partir da in filtração de liquidos

- Aspectos estëticos

- Possibilidade da ocorrência de maus odores, princi palmente quando sjo utilizadas lagoas anaeröbias

- Desvalorização de àreas adjacentes

Assim, podem ser consideradas välidas as observaçöes 
feitas para o aterro sanitärio, em termos de tipos de solo para servir de base às lagoas, bem como o posicionamento das mesmas em relaçäo aos recursos hídricos superficiais e subterrâneos.do meśmo modo, são välidas as considerações feitas para os resídu os sólidos industrials, quando se utillzar lagoas de estabiliza çäo para tratamento de eśgotos ptacedentes de indústrias

A localização de lagoas em relação à ărea urbana é outro fator a considerar. Sob este aspecto, devem ser observa dos :

- local de lançamento do efluente tratado

- direção predominante do vento, principalmente no caso de lagoas anaeróbias

- posicionamento em relação às zonas residenciais, de recreação, e outros äreas mais sensíveis aos impac tos ambientais resultantes de lagoas de estabiliza ção

VICTORETTI, cita outros autores que recomendam um a fastamento mínimo das lagoas de 1.000 a 1.600 metros para os nücleos habitados, e de 400 a 500 metros para residencias iso ladas, com o fim de previnir quaisquer incovenientes, os quais possam gerar objeções locais ao emprego deste processo de trata mento. (61)

0 mesmo autor faz referências às experiências condu zidas, por mais de dois anos, junto às lagoas de estabilizaçãc de São José dos Campos, São Paulo, onde residências estavam si tuadas a cerca de 140 metros da unidade aeróbia e a 400 metros da anaeróbia, sem que tenha surgido incoveniente no que se refe re ao problema dos odores.

E öbvio que as características ambientais próprias de cada cidade definirãc as melhores localizaçōes para lagoas de estabilizaçäo. As distancias apontadas como satisfatórios servem como uma indiçção para a escolha do local.

Todas as observações feitas com relação ao lançamen de äguas residuärias são aplicäveis à disposicăo, no solo, de lodos resultantes de processos de tratamento de esgoto. 
5.2 .2 - Erosão do solo

Conforme jä comentado anteriormente, a urbanização contribui para acelerar o processo de erosão do solo.0s QUADRos 4.3 e 4.5 mostram valores indicando a erosão do solo em função das características topográficas e do tipo de uso do local. Po de ser observado maior processo de erosão em äreas com grande declive ou quando o processo de urbanizaçäo ainda está se desen volvendo.

- Serviço de Conservação do Solo, do Departamento de Agricultura dos Estados Unidos associa um incremento na erosäo do solo, e o consequente carramento de sedimentos, em äreas em processo de urbanização, indicando que nas mesmas ocorrem: (57)

(1) Um grande aumento do volume de escoamento super ficial de água, devido a:

a) Remoção da cobertura vagetal protetora

b) Exposição do sub-solo nu de formações geolögi cas menos permeäveis e/ou mais sujaitas a ero säo do que o solo original da superficie

c) Redução na capacidade dos solos de absorver as äguas de chuvo, devido a compactação cousa do por equipamentos pesados

d) Aumento das áreas de drenagem, causado pelas operações de nivelamentos, desvio e de cons truções de vias

e) Prolongada exposição de áreas alteradas e não protegidas, devido a problemas de programação elou dilatação das obras de construção

f) Redução do tempo de concentração do escoamen to superficial, causada por alteraçōes na de clividade, na distāncia ou na rugosidade das superficies

g) Aumento das superficies impermeāveis, associa do com a construção de vias, prédios, calça das, estradas a äreas de estacionamento

(2) Alteração no reģi ne da ăgua subterrânea, afetan do adversamente os sistemas de drenagem, a esta bilidade de encostas a a sobrevivencia de vegeta 
ção existente ou recēm-plantada

(3) Exposiçäo de materiais sub-superficiais com ca racterísticas rochosa, ácido ou seca ou, de al gum modo, nāo favorável ao desenvolvimento de ve getação

(4) Alteraçōes adversas dos sistemos naturais de dre nagem da ägua superficial, como resultado de construçöes e outras obras pröprias do frocesso de desenvolvimento

As principais consequências do erosão, no meio urba no, sāo:

- Obstrução de cursos d'j̃guo, aumentando as possibi lidades da ocorréncia de inundaçōes e causando pre juízos à navegação

- Redução da capacidade de armazenamento de água em reservatórios, prejudicando o abastecimento pübli co e industrial, a prätica je recreação ou de ou tro uso

- Alteração na qualidade da água, influindo na eleva ção do custo do tratamento, quando a mesma é uti lizada para abastecimento püblico ou industrial

- Alteraçōes ecológicas no ombiente aquätico. A mu dança na cor da ägua ou a deposição de materiais no fundo de reservatórios ou cursos d'àgua, pode causar reduçós nos tipos e quantidades de organis mos aquäticos

- Modificaçós na estrutura natural do soloprovocan do deslizamentos, rachaduras, fendas e outros efei tos que exigem obras de engenharia, às vezes one rosas, para reparos

As medidas de controle da erosāo em um meio urbano devem ser de caräter preventivo, podendo ocorrer sob duas for mas :

(1) pela própria orientaçāo no definição do uso e ocupação do solo de determinada área sob planeja mento

(2) atravès de tècnicas específicas de controle da 
erosjo, a serem adotadas, de modo temporário ou permanente, quando do desenvolvimento de determi nada àrea

Dentro do escupo do trabalho, comentaremos com mais detälhes a primeira técnica de controle, fazendo apenas indica ções com relação ao seguindo caso:

Uim plano de controle de erosão deve iniciar-se cam um completo levantamento das características relicianadas ao processo, devendo incluir:

- Levantamento topogrä́ico, para classificação das diversas āreas por declividade do terreno

- Identificação do sistema de drenagem, observando os caminhos naturais (ümidos e secos) de escoamen to das äguas, levando em consideração os efeitos das äreas adjacentes sobre a regiāo em estudo

- Determinaça das características dos solos, identi ficando as äreas críticas, mais sujeitas à erosão

- Identificação ja vegetação natural do lugar

Partindo do conhecimento de todos os aspectos que po dem influir no processo de erosão, fica mais fäcil o seu contro 1e.

o princípio básico no controle da erosão é o seguin te :

PLANEJAR O USO E OCUPAÇÃO DO SOLO EM COMUM ACORDO COM A PRESERVAÇAOO DAS CARACTERTSTICAS TOPOGRAFICAS, DE SOLO, DE DRENAGEM DA AGUA, E OA VEGETAÇÃO NATURAL DO. LOCAL.

Com base neste principio, enumeramos, a seguir, algu mas medidas visando o controle da erosão:

(a) Ocupação do solo em funçãon da declividade do ter reno

Áreas em declive acentuado são mais sujeitas à ero são e seus efeitos, devido à ocorréncia de maior escoamento su perficial da ảgua.

Assim, uma ocupação ordenada das encostas, reduzindose a intensidade de ocupação e, portanto, o densidade de cons trução, em função do maior declive, è uma medida de grande im 
portância no controle preventivo do erosão.

Alguns Estados e Condados dos Estados Unidos tēm de finido dimensöes de lotes e porcentagens de äreas do solo a per maneceram em seu estado natural, em função da declividade do terrenos

No QUADRO 5.3, transcrevernos valores determinados pe la Comissão de Planejamento e Desenvolvimento da Regiáo de llon tanhas do Estado da Georgia.

Observamos, neste Quadro, valores elevados para as dimensōes dos lotes, comparados com as padrōes brasileiros. 0 mesmo serve apenas como exemplo de um modelo de ocupação consi derando a declividade do terreno.

No entanto, podemos aproveitar a idéia, adaptando às condiçōes específicas de caśa caso em estudo, as porcentagens de áreas recomendadas para permanecerem no estado natural. Ali às, sugerimos que o controle seja feito definindo-se taxas de ocupação do solo em função da declividade.

Para adaptar-se às taxas de ocupação, as dimensões dos lotes variarõo, sendo maiores onde for maior a ärea a perma necer em estado natural.

Ainda como sugestão, para adaptaçãas em função das caracteristicas pröprias do local, apresentamos o QUADRo 5.4, qual mostra as porcentagens de solo exigidas a permanecerem em estado natural em três condados dos Estados Unidos, em função da declividade do terreno.

Jä o Condado de Dovidson, Tenessee, sugere intervalos de declividades indicados para cado uso do solo, conforme mos tramos na FIGURA 5.2. E enfatizado, no entanto, que os interva los recomendados servem apenas como um guia geral, "uma vez que outros fatores podem contribuir para aumentar ou diminuir os $1 \mathbf{i}$ mites considerados".

os exemplos indicados até agora, embora apresentando valores diferentes, têm um só objetivo: uma taxa de ocupação do solo cada vez menor, a medida que aumenta a declividade do ter reno. Além do controle da erosão, este disciplinamento tem ou tros objetivos, tais como: preservaçäo da paisagem (controle da poluição visual); drenagem adequada das águas; preservação da vegetaça para outros fins; aspectos relacionados com a estabi lidade das construções. 


\begin{tabular}{|c|c|c|c|c|c|}
\hline \multirow{2}{*}{ USO DO SOLO } & \multicolumn{5}{|c|}{ DECLIVIDADES } \\
\hline & $0-5 \%$ & $5-12 \%$ & $12-20 \gamma_{6}$ & $20-30 \psi_{0}$ & $30+\psi_{0}$ \\
\hline AREA de pREservacto & & & & $L$ & WIIIII \\
\hline RECREACTO PABSIVA & & & & IIII & - \\
\hline AORICULTURA & & 1 & & & \\
\hline RECREACATO ATIVA & سمح & & & & \\
\hline BAIXA DENSIDADE RESIDENCIAL & & & & & \\
\hline MÉDIA DENSSIDADE RESIDEENCIAL & & IIII & $\square$ & & \\
\hline USO DE MÉDIA INTENSIDADE & & IIWDO & & & \\
\hline USO DE MÉDIA-ALTA INTENSIDADE & DIllilli & D] & & & \\
\hline USO DE ALTA INTENSIDADE & Ilimilla & & & & \\
\hline
\end{tabular}

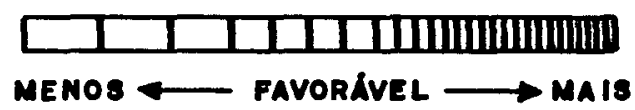

OBSERVACŌES:

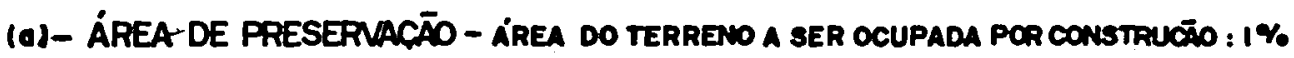

(b)- ÁREA DE RECREACĀO PASSIVA - AREA A SER OCUPADA : I A 3\%.

(c)- AGRIC̄ULTURA - AREA SER OCUPADA : I A S\%.

-(0) - RECREACÃO ATIVA - AREA A SER OCUPADA: 3 A.10\%

(0) - BAIXA DENSIDADE RESIDENCIAL - ÁREA A SER OCUPADA : $10 \wedge 25 \%$

(f)- MÉDIA DENSIDADE RESIDENCIAL - ÁREA A SER OCUPADA : 25 A 45\%

(0) - USO DE MÉDIA INTENSIDADE : APARTAMENTO, PEQUENO COMERCIO E INDUSTRIAS -

- AREA A SER OCUPADA : 25 A $55 \%$

(h) - USO DE MÉDIA-ALTA INTENSIDADE : COMÉRCIO E MÉDIAS INDUSTRIAS - ÁREA a SER OCUPADA: 55 A TS\%

(1)- USO DE ALTA INTENSIDADE: COMÉRCIO INTENSO, GRANDES INDUSTRIAS, : GRANDES COMPLEXOS DE APARTAMENTOS - AREA A SER OCUPAOA : 75 A $100 \%$ 


$$
\text { QUADRO } 5.3
$$

Lotes mínimos em funçāo da declividade do terreno. Região Montanhosa do Estado de Georgia. Estados Unidos.

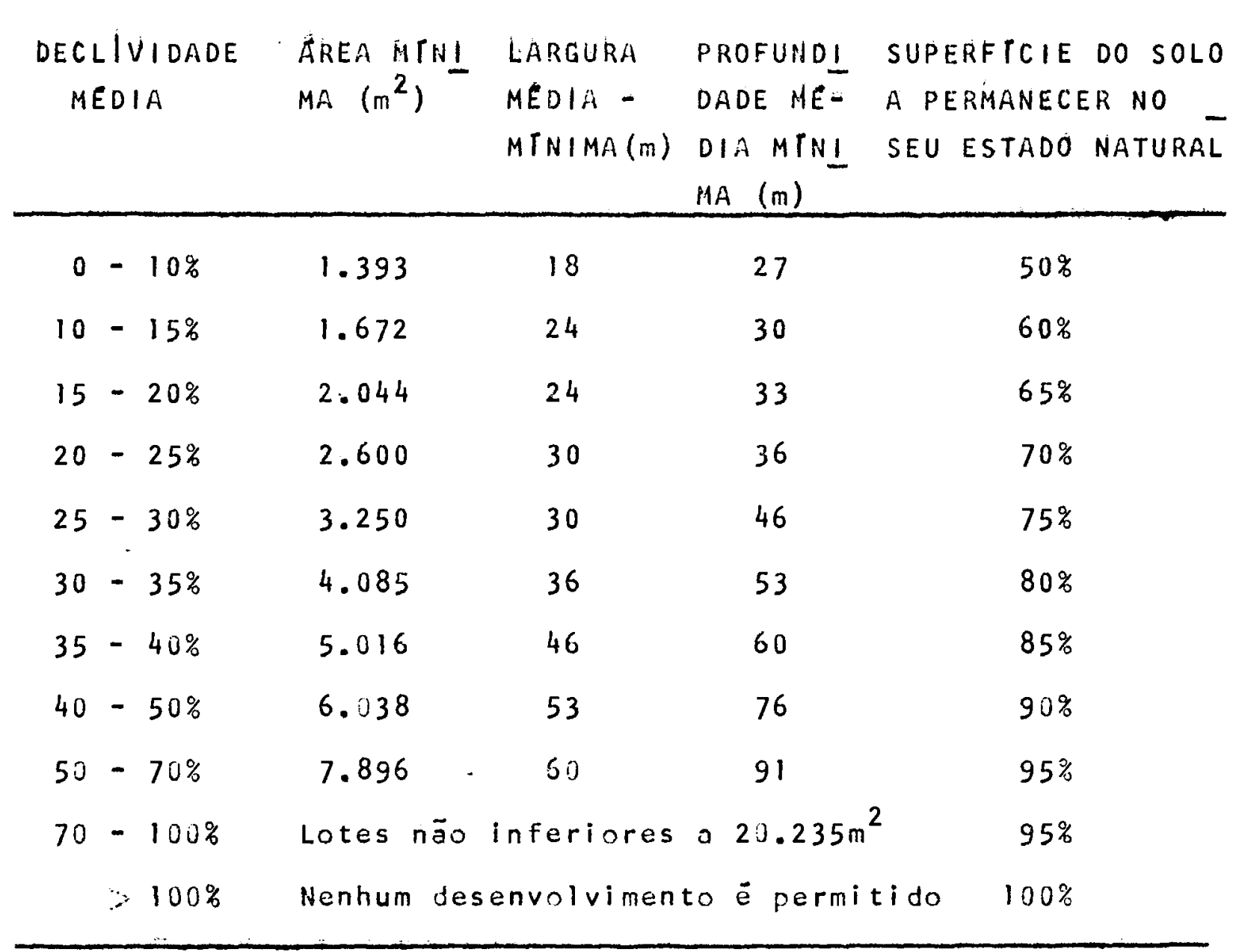

FONTE: GEORGIA MOUNTAINS PLANNING AND DEVELOPMENT COMMISSION (22)

Obs: DECLIVIDADE $(\%)=\frac{\text { DISTANCIA VERTICAL }}{\text { DISTANCIA HORIZONTAL }} \times 100$ 


$$
\text { QUADRO } 5.4
$$

ocupação do solo em função da declividade do terreno: Condados dos Estados Unidos da América

\begin{tabular}{|c|c|c|c|}
\hline INCL INACÃO & PORCENTAGEM DA FREA & A PERMANECER & EM ESTADO NATURAL \\
\hline MEDIA $(\%)$ & $\begin{array}{l}\text { CHULA VISTA } \\
\text { CALIFORPIA }\end{array}$ & $\begin{array}{l}\text { PACTFICA, } \\
\text { CALIFORNIA }\end{array}$ & $\begin{array}{c}\text { THOUSAND OAKS, } \\
\text { CALIFORNIA }\end{array}$ \\
\hline 10 & 13,75 & 32 & 32.5 \\
\hline 15 & 31,25 & 36 & 40,0 \\
\hline 20 & 43,75 & 45 & 55,0 \\
\hline 25 & 62,50 & 57 & 70,0 \\
\hline 30 & 90,00 & 72 & 85,0 \\
\hline 35 & 90,00 & 90 & 100,0 \\
\hline 40 & 90,00 & 100 & 100,0 \\
\hline
\end{tabular}

FONTE: THUROW, C. et al. (48) 
Ás taxas de ocupação em função da declividade variam em função de värios fatores: tipo de solo; vegetação; escoamen to natural das äguas; extensão do declive; tipo de ocupação de sejada. Assim sendo, preferimos indicar intervalos de densida des de ocupaçāo em função da declividade, conforme mostrado na FIGURA 5.3. A escolha dos valores exatos para as diversas taxas de ocupação fica a critério dos planejadores, dependendo das ca racteristicas especificas de cada local.

Neste caso, deve ser entendido como "ärea ocupada", todo terreno impermeabilizado por construções ou pavimentaçöes de vias públicas. Ou seja, a ärea restante é a que deve permane cer em seu estado natural.

(b) Areas adjacentes aos cursos d'ägua e reservatör os

Os terrenos situados às margens de coleçōes superfi ciais de àgua têm grande importância no controle da quantidade deste líquido que alcança os mananciais.

Dependendo das condifóes existentes, maior ou menor quantidade de ägua é "retida" nas märgens. Para isto, a vegeta ção e as condiçōes de permeabilidade do terreno existentes mui to contribuem.

Quando há uma ocupação intensa, por construções, vias püblicas ou cutras obras que resultam na impermeabilização do solo, hä um aumento no líquido escoado e, consequentemente, mai or potencial de erosão.

Por isto, é recomendável a adoçäo de faixas de terra praticamente em condições naturais, às mārgens de coleçōes su perficlais, para diminuir o escoamento superficial, reduzir a erosäo e, consequentemente, a ocorréncia da enchentes.

A largura desta faixa é mais função das condições da drenagem do local e pode ser associada a uma faixa de proteção sanitäria, conforme veremos posteriormente.

(c) Areas de solos mais sujeitos a erosão

Determinadós tipos de solos estão mais sujeitos à e rosão, devido as suas próprias características de desagregação.

Areas com solos deste tipo devem ser identificadas e protegidas atravēs de preservaçāo total ou fixaçāo de pequena densidade de ocupação para as mesmas. 


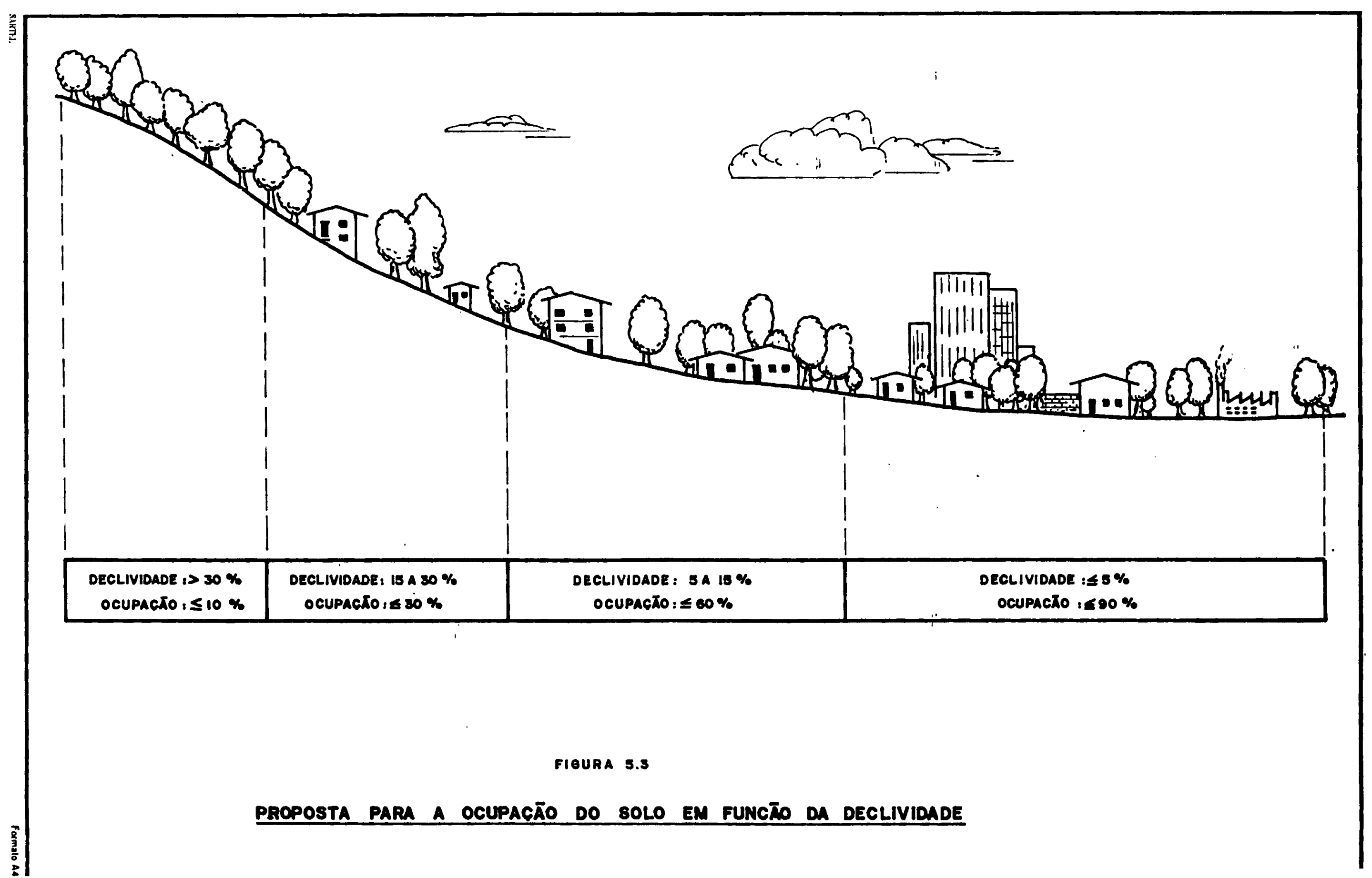


Estes locais poúem ser destinados para äreas de la zer, mantendo-se uma vegetação protetora sobre os mesmos.

(d) Escoamento natural das äguas

Toda bacia hidrog̣āifica tem um escoamento natural das äguas, seja èm vales úmidos - rios, riachos, ou em vales se cós; por onde a água escoa após precipitacóes pluviométricas.

Alterações no sistema nätüräi de drenagem,atravēs de obras de construçōes ou aterratientos; notmalmente; provocam um incremento no processo de erosäo, alëm de outras consequenclas indesejāveis.

Este aspecto deve ser considerado, procurando-se, an mäximo, respeitar o escoamento natural. Nos casos de haver ne cessidade de mudanças nos cursos normais das äguas, as mesmas devem ser executadas após cuidadosa análise dos efeitos que po dem resultar destas alterações.

Na FIGURA 5.4 mostramos dois esquemas indicando ma neiras CERTA e ERRADA de ocupação do solo, em função da drena gem natural da ägua.

(e) Cobertura vegetal

A vegetação constitui fator mais importante no con trole da erosäo, principalmente porque:

- constitui barreira física ao transporte do materi al

- proporciona uma estrutura mais sólida an solo, de vido ao sistema radicular

- amortece o impacto das äguas de chuva sobre o solo

- eleva a porosidade do solo e, portanto, sua capaci dade de absorção da àgua

o transporte de solo é muito reduzido nas regiōes on de o solo é coberto de àrvores ou de capim. De um modo geral,as gramíneas, possuidoras de denso sistema radicular superficial em forma de cabeleira, são particularmente vantajosas para a fi. xaçāo da terra. (10)

De um modo geral, podem ser seguidos os seguintes princípios de controle da erosão, relacionados com a vegetação:

(1) Oncle o uso do solo nāo requer a remoção de àrvo 


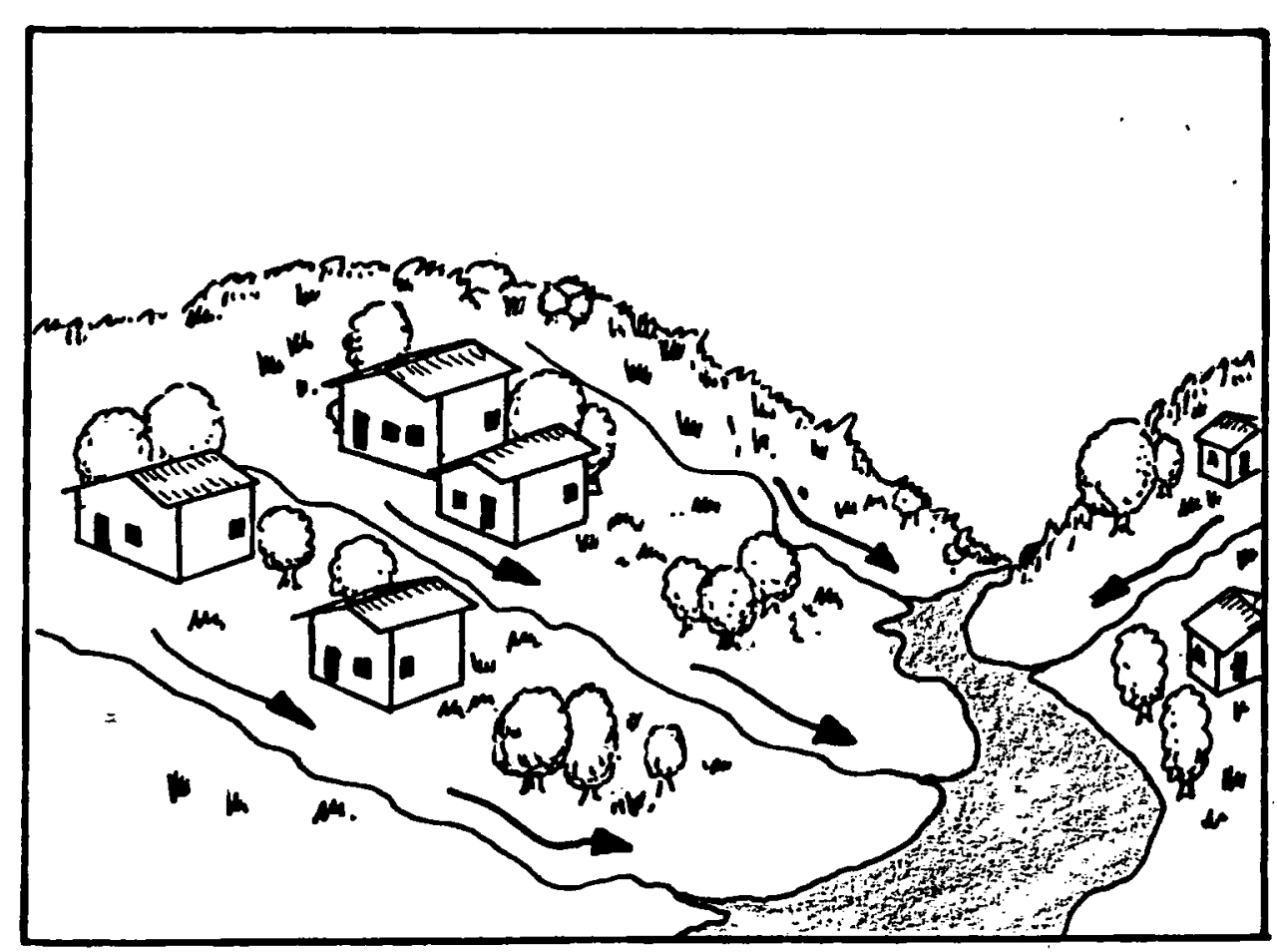

O CUPACĀO CERTA

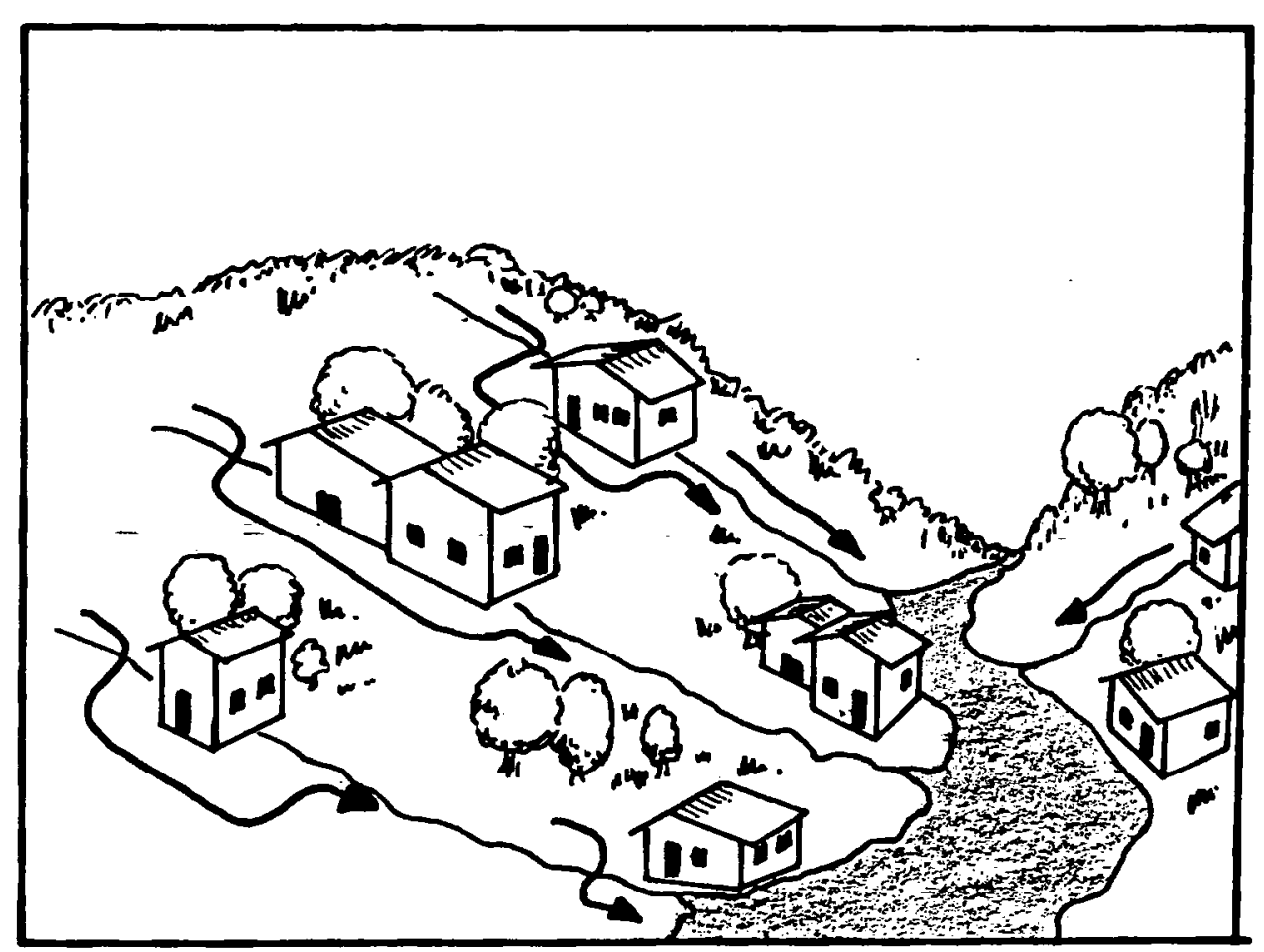

OCUPACĀO ERRADA 
res ou de outra vegetação natural, as mesmas de vem ser mantidas e preservadas

(2) Ònde existe uma vegetação Inadequada, deve-se su bstiturta por outra mals conveniente

(3) Áreas críticas com respeito à erosão devem ser protegidas por vegetação adequada. Por exemplo: encostas, márgens de cursos d'água e áreas de so los facilmente desagregäveis.

(f) Outras medidas de controle

Alèm das medidas jä citadas, outras pedem ser adota das, em caräter permanente ou temporärio, principalmente em à reas sujeitas a intenso processo de desenvolvimento. Entre es tas, podemos citar:

- Proteção das äreas expostas a erosão por vegetação temporária ou outro material que contribua para a conservação da umidade, agregaçãc do solo e a fixa ção da cobertura vegetal

- Expor os solos de äreas em desenvolvimento, o mini mo período de tempo possivel

- Procurar expor a menor ärea de terra possível

- Executar obras para dirigir os fluxos de ägua no terreno ou retê-los, tais como: valas de escoamen to (canais); pequenos diques interceptadores; bar ragens de acumulação; drenos, etc.

- Construção de vias acompanhando o contorno natural do terreno

5.3 - Uso do solo e controle da poluição da ägua

No item 4.3 .2 mostramos os diversos mecanismos atra vès dos quals pode ocorrer a poluif̧ão da ägua em um meio urba no. De modo resumido, podemos dizer que as causas mais comuns de poluição da ảgua em cidades são:

- lançamento de esgotos domésticos e industriais

- efluentes de fossas sépticas, alcançondo o lençol freatico 
- äguas resultances do escoamento superficial

- líquidos infiltrados a partir de resíduos sölidos ou líquidos depostitados no solo

o conhecimento destas causas e de como as mesmas pro vocam a poluição da āgua, já discutidos anteriormente, conduzirá à adoção de medidas visando seu controle. As präticas de contro le discutidas neste trabalho seräo as de caräter preventivo, re lacionadas com o planejamento do uso do solo.

No disciplinamento do uso do solo urbano visando a preservação dos recursos hídricos devem ser abordados:

(a) a capacidade de infra-estrutura sanitäria exis tente ou projetada

(b) a proteção e recarga do lençol freätico

(c) a preservação de reservatórios e cursos d'água superficiais

\subsection{1 - Capacidade da infra-estrutura sanitäria existente ou projetada}

A existência, ou não, de sistemas de abastecimento de ägua e esgoto influi consideravelmente no processo de uso-0 cupação de determinada ärea urbana.

Por isto, quando se vai planejar uma cidade, ou par te desta, deve-se, em primeiro lugar, levantar os serviços de ägua e esgoto disponíveis. A partir daí, deverão ser definidos os melhores usos para cada zona da cidade.

Infelizmente, nem sempre isto é feito, e os proble mas de saneamento resultantes são inümeros.

Pensando-se em termos de uma habitação unifamiliar, os problemas são mínimos, podendo-se, quase sempre, resolvê-los atravēs de soluçöes individuais tipo poço e fossa. Porēm, a me dida que o terreno é ocupado por mais familias - habitaçōes mul tifamiliares, as soluçöes individuais, principalmente para o es goto, tornam-se impraticáveis, pois seriam necessärias äreas de terreno muito grandes para absorver os efluentes de fossas.

o problema agrava-se ainda mais com relaço aos pré dios de uso coletivo ou industriais, pois as contribuições de 
esgoto são ainda maiores.

Assim sendo, a definição da usos do solo para uma ci dade deve ser feita em função da infra-estrutura sanitäria exís tente ou projetada, observando-se as "capacidades de absorção" dos consumos adicionais de água e das contribuições a mais de esgotos.

Como fatores limitantes desta "capacidade de absor ção", podem ser citados:

- Volume de àgua disponível no manancial de abosteci mento

- Capacidade da Estação de Tratamento da àgua, atual e prevista para o futuro

- Dimensões dos outras partes componentes do sistema de abastecimento de água - adutoras,reservatirios, redes de distribuiçän, atuais e futuros

- Dimensões da rede coletora de esgoto, existente e projetada

- Capacidade da Estação de Tratamento de Esgoto, atu al e futura

- Capacidace do corpo d'ägua receptor de receber car ga adicional le efluente tratado

A não observância desta "capacidade de absorção" tem resultado em inümeros problemas, muito comuns em cidades brasi leiras: fornecimento de àgua em quantidade insuficiente, em de terminadas äras; sistema de fossas/sumidouros causando polui ção do solo e da água; estações de tratamento de esgoto funcio nando com baixa eficiéncia; lançamento indevido de äguas resi duärias ém galerias pluviais, reservatórios e cursos d'ägua, ou no oceano; indüstrias sem condiçoes de funcionamento, devido a escassez de água ou a inexistência de um sistema coletor de es goto.

Muitos destes problemas podem ser evitados orienta do-se o uso- ocupação do solo em função da capacidade da ärea de "fornecer" ägua e "receber" esgotos.

Este controle pode ser feito através de:

- Definição de uso-ocupação do solo adequado à ärea

- Definição de densidade: compatíveis com a infra-es trutura existente ou projetada 
- Adoção de soluções individuais, temporärias ou per manentes, mas levando em consideração os aspectos ambientais pertinentes. Um exemplo disto è a defi nição de lotes mínimos em função da capacidade do solo de receber esgotos a partir de sistemas fos sas/sumidouros:

A localização de uma zona industrial deverá conside rar as facilidades de fornecimento de ägua às fäbricas e os me os para afastamento dos resíduns líquidos.

Prédlos de habitação multifamiliar de determinado porte devem ser proibidos em äreas onde não existe rede coleto ra de esgotos e é impossível, sob o aspecto prātico, a absorção do líquido no solo. Mesmo as habitaçōes unifamiliares devem ser restritas às äreas onde, não existindo sistema de esgoto, as con diçōes de solo e de lençol freātico sejam favorāveis a soluções individuais.

Um planejamento do uso do solo que considere todos estes aspectos, por certo minimizarä os problemas de poluiçāo dos recursos hídricos em äreas urbanas.

A implantação da infra-estrutura sanitäria pode ser usada, tambēm, como um fator favorecedor ou não do desenvolvi mento da cidade em determinadas äreas. Em zonas da cidade onde não hä interesse de que seja procedida a urbanizaçāo, pode-se não projetar e executar os serviços de saneamento, como meio de dificultar o seu desenvolvimento. Areas de difícil obtenção de ägua, por exemplo, podem permanecer não ocupadas, se näo forem servidas por uma rede püblica.

Como exemplo, podemos citar a ocupação de determina do trecho de dunas na zona litoránea de Fortaleza. A construção de um reservatōrio de ägua numa cota a partir do quol foi possí vel abastecer as dunas, permitiu uma ocupação rápida do solo por residencias, Frivando a cidade desta ārea de grande valor paisagístico. A provável dificuldade de obtençāo de ägua reria criado embaraços a este desenvolvimento.

Em resumo, podemos dizer que o uso-ocupação do solo deve ser feito em função do infra-estrutura sanitäria existente ou projetada, bem como que se deve projetar os serviços de sa neamento para as densicades populaciunais previstas ou desejá veis para determinada ārea. 
A poluiça da àgua subteriànea a partír de dépósitos de resíduos sölidos ou líquidos no solo, foi comentada no ítem referente à poluição do solo (4.3.i),

Uma outra forma de ocorrèr a poluição da água a par tir do lançamento de residuos líquidos no solo é através de é fiuentes de fossas sēpticas, os quais, normalmente, déstinam-se a sumidouros ou valas de infiltração.

A fossa séptica é a solução individual maís indicada na ausência de uma rede coletora de ésgoto. obviamente, a sua adoção dependerá de diversos aspectos relacionádós com o amblen te hidro-geolögico que receberá ó seu efluente. No entanto;quan do bem projetada, executada é mantida, e quando colocada em lo cai aproprlado; pode apresentar resultados satisfatorios.

Muitas cidades brasileiras ainda faräo uso desta so luçäo de destino final de esigotos por multo tempospodemos dizer que a mesma é recomendävel para pequenas comunidades, uma vez que o elevado custo de um sistema coletor de esgoto torna-o im praticävel nestas localidades. Esta recomendação é ainda mais välida quando existir o sistema püblico de abastecimento de á gua.

A anälise dos diversos aspectos que influem numa mai or ou menor eficiência da fossa séptica, conduzirá a uma minimi zação dos efeitos sobre o ambiente, tornando praticável esta só lução.

No planejamento do uso do solo de uma cidade que não dispõe, total ou pacialmente, de um sistema de esgoto sanitā rio, devem ser observadas todas as condiçōes ambientais relacio nadas com a disposiça de efluentes de fossas no solo, para a elaboração de um mapa indicanco as áreas prōprias e imprōprias a utilizaçoo de soluçōes individuais de destino final do esge to.

São sete os aspectos a serem observados nesta anāli

se:

- Características geológicas do terreno

- Permeabilidade do solo. Capacidade de absorção

- Profundidade do lençol freático

- Direção e taxa de escoamento do fluxo d'ãgua sub terrânea 
- Declividade do terreno

- Afastamento entre a fóssalsistemá de ábsorcão do efluente e corpos superficiais de ăgua ou poços

- Profundidade da camada de rocha impermeāvel

(a) Cáracterísticas geológicas do terreno

Jä dissemos que o solo aje como um "purificador" de líquidos, através de uma seerie de processos físicos, químicos e biológicos que ocorrem quando a ägua percola neste meio.

A textura do solo influi bastante neste processo. So los tais como areia grossa e cascalho têm pouco poder de "puri ficaçă", alēm de permitirem grandes distâncias de percurso dos polventes:

Outro aspecto a observar é a existêncla de fraturas nas rochas do sub-solo, que poderão permitir a penetração do lí quido efluente a grandes profundidades.

outras características geolögicas devem ser conside radas, tais como a permeabilidade (capacidade de absorção), ní vel e movimento da água subterrânea, e profundidade de camadasimpermeáveis, as quais serão discutidas a seguir.

(b) Capacidade de absorção

A permeabilicade do solo indicarā a quantidade de à gua que se infiltrará em dada ärea, em determinado tempo. Esta capacidade é calculada através do teste de absorção do terreno, que è o modo mais indicado para se saber se um solo é apropria do para receber efluentes de fossas, principalmente quando se estudam lotes isolados.

o testa de absorçāo è disciplinado atravēs da Asso ciação Brasileira de Normas Técnicas - PNB 41 - expressa a quantidade de ägua (em litros) absorvida por metro quadrado, por dia, em determinado terreno.

Solos com alta permeabilidade lsolos com granulome tria maior) não são recomendados para receberem efluentes de fossas, devido à menor "purificação" que oferecem, e por propor cionarem maior distância de percurso do lquido em seu meio. Do mesmo modo, os solos de baixa permeabilidade (solos argilosos) não são indicados, pois proporcionam pouca infiltração do líqui do. 
No primeiro caso, incluem-se os solos com coeficien te de absorção superior a $1401 / \mathrm{m}^{2}$.dia e, no segundo caso; os solos com coeficlente de absorçäo inferior a $251 / \mathrm{m}^{2}$. díaj os so los pertencentes a estas duas faixas podem ser considerados im próprlos para a construçāo de soluçōes individuais de destino final de esgoto.

(c) Profundidade do lençol freático

A "purificaçāo" de líquidos percolando atravēs do so 10 a maior na zona nảo saturada do que na zona de saturação.Por isto, $\dot{e}$ importante manter-se uma certa distância entre o fundo do sumidouro ou da vala de infiltração e o nivel do lençol freá tico. Sendo este nível variàvel em função da época do ano, esta distância deve ser em relação ao nível máximo do lençol.

As distâncias recomendadas variam de $1,50 \mathrm{~m}$ a $3,00 \mathrm{~m}$, havendo maior exigência, em legislaços de Condados e Estados Americanos, para $1,50 \mathrm{~m}$.

Assim, pode-se adotar como satisfatöria uma distân cia mínima de $1,50 \mathrm{~m}$ entre o fundo do sistema de infiltraçän de efluentes de fossas e o nível máximo observado do lençol freäti co.

(d) Direção e taxa de escoamento da àgua subterrânea

0 movimento da ägua subterrânea na zona de saturação é determinado pelas condições hidräulicas existentes.

0 sentido do fluxo da ägua subterrānea, normalmente, acompanha a topografia do terreno. Observando-se a topografia do terreno, podemos arever um fluxo de àgua no sub-solo acompa nhando a inclinação natural do terreno, no sentido das àreas al tas para as mais baixas.

Esta observação conduz à recomendaçāo de que, sempre quando possível, os poços devem s:tuar-se na parte mais alta do lote.

(o) Declividade do terreno

A declividade da superficie do terreno ë outro fator 
que deve ser considerado. Efluentes de fossas lançados em terre nos com grande declividade podem aflorar nas äras inferiores e daí escoar na superfícle dó solo.

Ém terrenos com declividade superior a $20 \%$, o siste ma de fossa séptica deve ser usado com cautela.

Uma medida atenuante deste problema é a execução de valas de infiltração acompanhande o contorno do terreno.

(f) Distância para corpos superficiais de àgua e po ços

O movimento de poluentes no sub-solo fol discutido no item 4.3.2.2.2. Pelo que foi visto, parece recomendável um afastamento de, no mínimo, 30 metros entre o local de lançamen to de esgotos domésticos no solo, e coleções superficiais e sub terrāneas de àgua.

No QUADRO 5.5 compilamos algumas distāncias mínimas exigidas por legislaçẽes americanas, entre a ārea de disposição de efluentes de fossas e coleções d'ägua, edificações e outras estruturas. Com base nos dados apresentados, podemos manter a recomendação de afastamento mínimo de 30 metros, para poços e formações superficiais de àgua.

(g) Profundidade da camada de rocha impermeável

Uma outra observação a ser feita è com relação à pro fundidade da camada de rocha impermeāvel. Para que ocorra a ne cessäria infiltração è necessário que abaixo da ärea de infil tração exista uma camada de rocha não consolidada com, no míni mo, $1,80 \mathrm{~m}$ de espessura.

Locais com rochas impermeáveis muito próximos à sü perficie não devem ser utilizados. 


\section{QUADRO 5.5}

Afastamentos recomendados para äreas de infiltração de efluen tes de fossas. Éstados Unidos da América.

\begin{tabular}{|c|c|c|c|}
\hline AFASTAMENTO HTNIHO DE & $\begin{array}{c}\text { PENHSYLVANIIi } \\
\text { (a) }\end{array}$ & $\begin{array}{l}\text { CONDADO DE } \\
\text { WESTCHESTER } \\
\text { N.Y. (b) }\end{array}$ & $\begin{array}{l}\text { CONDADO DE } \\
\text { DAVIDSON, } \\
\text { TENNESSEE (c) }\end{array}$ \\
\hline Poços & $30 \mathrm{~m}$ & $30 \mathrm{~m}$ & $15 \mathrm{~m}$ \\
\hline $\begin{array}{l}\text { Cursos diagua; lagos } \\
\text { e lagoas }\end{array}$ & $15 \mathrm{~m}$ & $30 \mathrm{~m}$ & $7.5 \mathrm{~m}$ \\
\hline $\begin{array}{l}\text { Tubulaçäo d'ăgua sob } \\
\text { pressão }\end{array}$ & $7.5 \mathrm{~m}$ & $6 m$ & $3 m$ \\
\hline Limites do lote & $3 m$ & $3 m$ & $4.5 \mathrm{~m}$ \\
\hline Tubulações de sucção & & & \\
\hline de ägua & $30 \mathrm{~m}$ & $30 \mathrm{~m}$ & - \\
\hline Edificações & $3 m$ & $6 m$ & $3 m$ \\
\hline Arvores & $3 m$ & $3 m$ & $3 m$ \\
\hline
\end{tabular}

FONTES: (a) THE PENHSYLVANIA STATE UNIVERSITY (25)

(b) COUNTY OF WESTCHESTER, N.Y. (50)

(c) DAVIDSON COUNTY, TENNESSEE (51) 
o conjunto de informações levantadas em detèrminado ărea, com réspeito aos sete aspectos aqui comeritados,permitiräo a elaboração de um mapa onde poderão ser assinaladas três żo nas:

ZONA ADEQUADA - onde sistemás de, fóssas sēpticas pe dem ser executados sem maiores réstriçñes.

ZONA ADEQUADA, COH RESTRIÇÕES - onde podem ser cons truídos estes sistemas; adaptando-se o terreno de forma a melhorar suas condições.

ZONA INADEQUADA - āreas unde è impossível a execuçäo deste tipo de solução individual para esgoto.

$\mathrm{Na}$ FIGURA 5.5, mostramos um exemplo de um mapa de zo neamento das äreas próprias e impróprias para uso de sistema fossa/sumidouro ou vala de infiltraçäod

E claro que mapas deste tipo constituem uma primeira idéi a das condiçöes do local e podem ser utilizadas como indica dores, no planejamento do uso do solo sob o ponto de vista ambi entall Tratando-se de informaçōes subre ns aspectos hidro-geolo gicos de uma vasta ärea, seria impossível a apresentação de ín formações muito precisas.

Quando da solicitação de aprovação de projetos de lo teamentos ou de construçōes, informaçöes mais detalhadas devem ser exigidas com relação às características do solo,especialmen te as relativas à profundidade do lençol freático e ao coefici ente de absorção.

Este exame mais apurado do local pode inclusive indi car que as características do terreno são melhores, ou piores, do que as previstas no mapa.

No entanto, è muito vālida a elaboração do mapa, sen do o mesmo bastante ütil na fase de um planejamento geral de uma ärea urbana.

A utilização de sistemas individuais de tratamento e destinação final de esgoto no terreno deve definir, também, as dimensöes dos lotes.

E claro que em locais servidos por redes de água e esgoto, não existe a preocupação em se deixar grandes áreas li vres para campo de absorção de efluentes de fossas. Porëm, onde 


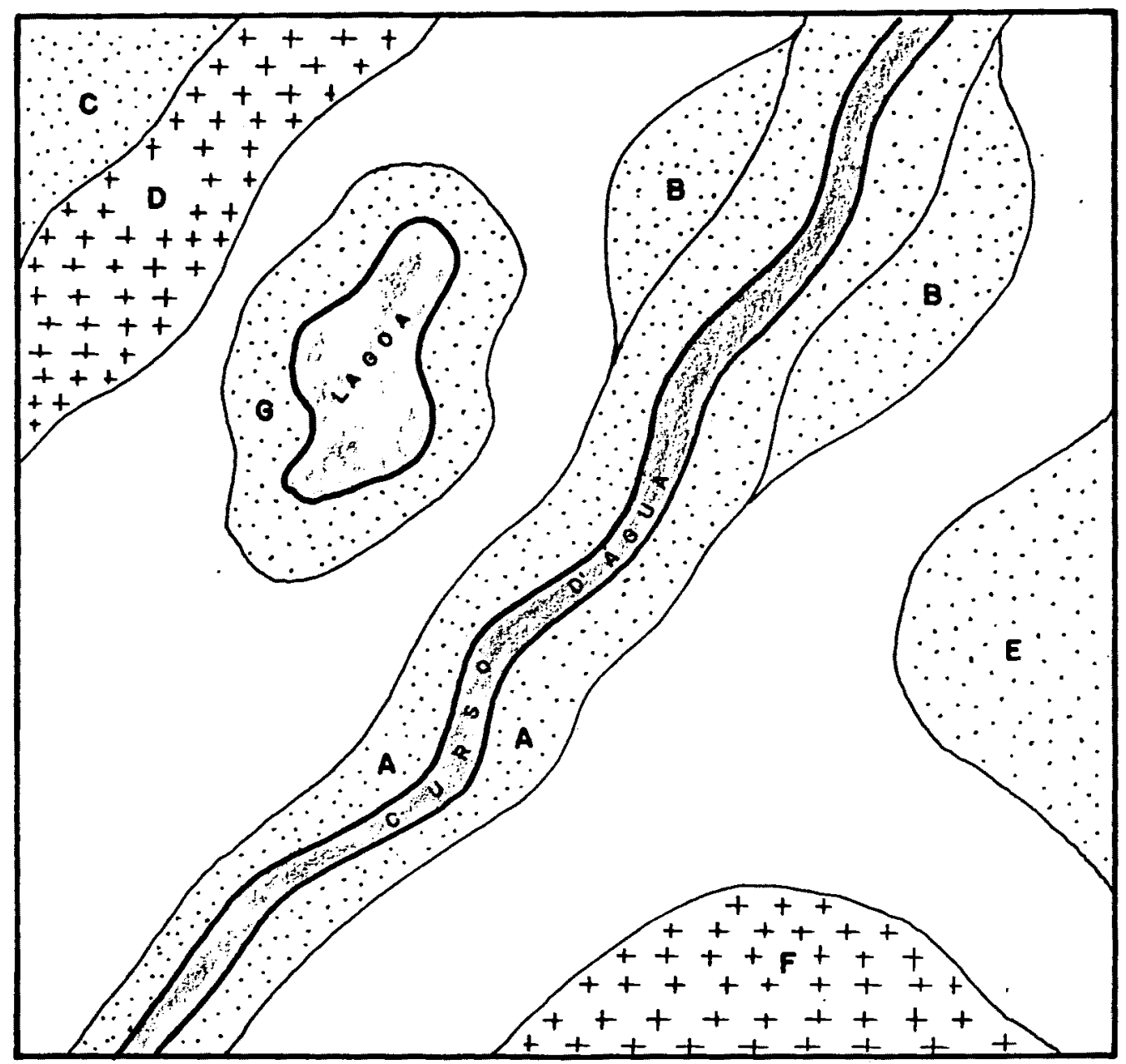

CONVENCŌES:

ZONA ADEOUADA

$+t+t$
$++t+t$

$t+t+t$

ZONA ADEQUADA. D- TERREMO con MEOHA DECLIVIDADE COM RESTRIÇŌES F- SOLO CON BAIXO COEFICIENTE dE ABSORCÃO

ZONA INADEOUADA
A - MAROENS DE CUR8O D' LOUA
B - Lrea alagada
C - terremo con orande declive
F - rocha IMPERMEÁvel afloRamdo
O - mageera de lacoA

\section{ZONEAMENTO DE AREAS PARA USO DE SISTEMAS} FOSSA/SUMIDOURO OU VALA DE INFILTRACATO 
estes sistemas nāo existem, a divisão de terrenos em lotes deve levar em consideração este aspecto.

Devemos, então considerar très situaçōes:

(1) A área planejada dispóe de serviços püblicos de água e esgoto. Neste caso, os lotes podem ser me nores, permitindo-se maiores adensamentos popula cionais, dependendo de outros fatores urbanisti $\cos$

(2) A ärea planejada conta somente com serviço pübli co de àgua. Nesta hipótese, devem ser analisados os aspectos do terreno com reloção a sua capaci dade de absorver o líquido residual

(3). Na äreo planejada não existem serviços püblicosde āgua e de esgoto. Heste caso, a āgua deverá ser obtida do próprio sub-solo do lote, exigindo maiores restrições na execução da fossa, princi palmente em termos de afastamento do poço. Isto conduzirà necessidade de lotes maiores.

E comum encontrar-se em legislaçöes americanas que dispöem sobre loteamentos, a fixação dos tamanhos dos lates em função da existência ou não da infra-estrutura sanitäria.

Para a cidade. de El Paso, Texas, por exemplo,são fei tas as seguintes exigências: (49)

- Zona com sistemas de água e esgoto: lotes com áre as inferiores a $929 \mathrm{~m}^{2}$

- Zona contando com serviço de āgua ou de esgoto: 1o tes com ärea variando de $929 \mathrm{~m}^{2}$ a $3716 \mathrm{~m}^{2}$

- Zona não servida por redes de āgua e esgoto: lotes com ärea superior a $3.716 \mathrm{~m}^{2}$

A cidade de Millcreek, do Condado de Erie, Pennsylva nia, tambèm determina dimensōes mínimas para lotes residenci ais, em função das condições de saneamento bäsico: (53)

- Zona com serviços püblicos de ägua e esgoto:

largura mínima do lote - $21 \mathrm{~m}$

ärea minima do lote $\quad-668 \mathrm{~m}^{2}$ 
- Zona com servico público de água, mas sem serviço püblico de esgoto:

largura mínima do lote $-24 \mathrm{~m}$

área minima do lote $-1.393 \mathrm{~m}^{2}$

- Žona sem serviço püblico de ägua, mas com serviço püblico de esgoto:

làrgura minimo do lote - $21 \mathrm{~m}$

ärea mintima do iote $-975 \mathrm{~m}^{2}$

- Zona sem serviços pübilicos de ägua e de esgoto:

largura mínima do lote $-30 \mathrm{~m}$

ärea mínima do lote $-1.858 \mathrm{~m}^{2}$

No QUADRO 5.6, transcrevemos as dimensōes mínimas de lotes residenciois exigidas para a Cidade de Carleton, Michigan, e apresentadas em (24).

Como podemos observar, as dimensöes minimas dos lo tes exigidas em cidades americanas, mesmo para zonas providas de sistemas püblicos de saneamento bäsico, são muito grandes, comparadas com a realidade brasileira. os dados apresentados servem apenas como exemplo da que é possível estabelecer-se di mensöes mínimas para lotes, considerando a infra-estrutura sani täria existente no local.

Como sugestão, apresentamos nos QUADROS 5.7 e 5.8 , di mensöes minimas e índice de ocupação de lotes, em funçäo da in fra-estrutura sanitäria existente. Claro que estas dimensōes são para locais onde a utilização de fossas é possivel, dentro dos sete critérios comentados anteriormente. Ou seja, os valo res sugeridos são välidos para äreas consideradas ADEQUADAS Pa ra uso de sistemas de fossas sépticas.

OS QUADROS 5.7 e 5.8 foram elaborados considerando o seguinte:

- Contribuiçäo do esgoto: habitações: 200 litros por pessoa por dia prédios comerciais e de serviços: 50 litros por pessoa por dla

- Para cada habitação foi admitida uma mëdia de 6 pessoas

- Profundidade dos sumidouros: $2,0 \mathrm{~m}$ a $2,5 \mathrm{~m}$ 
QUADRO 5.6

Dimensões milrimas de lotes em função da infra-estrutura sanitá ria. Cidade de Carleton, Michigan, Estados Unidost

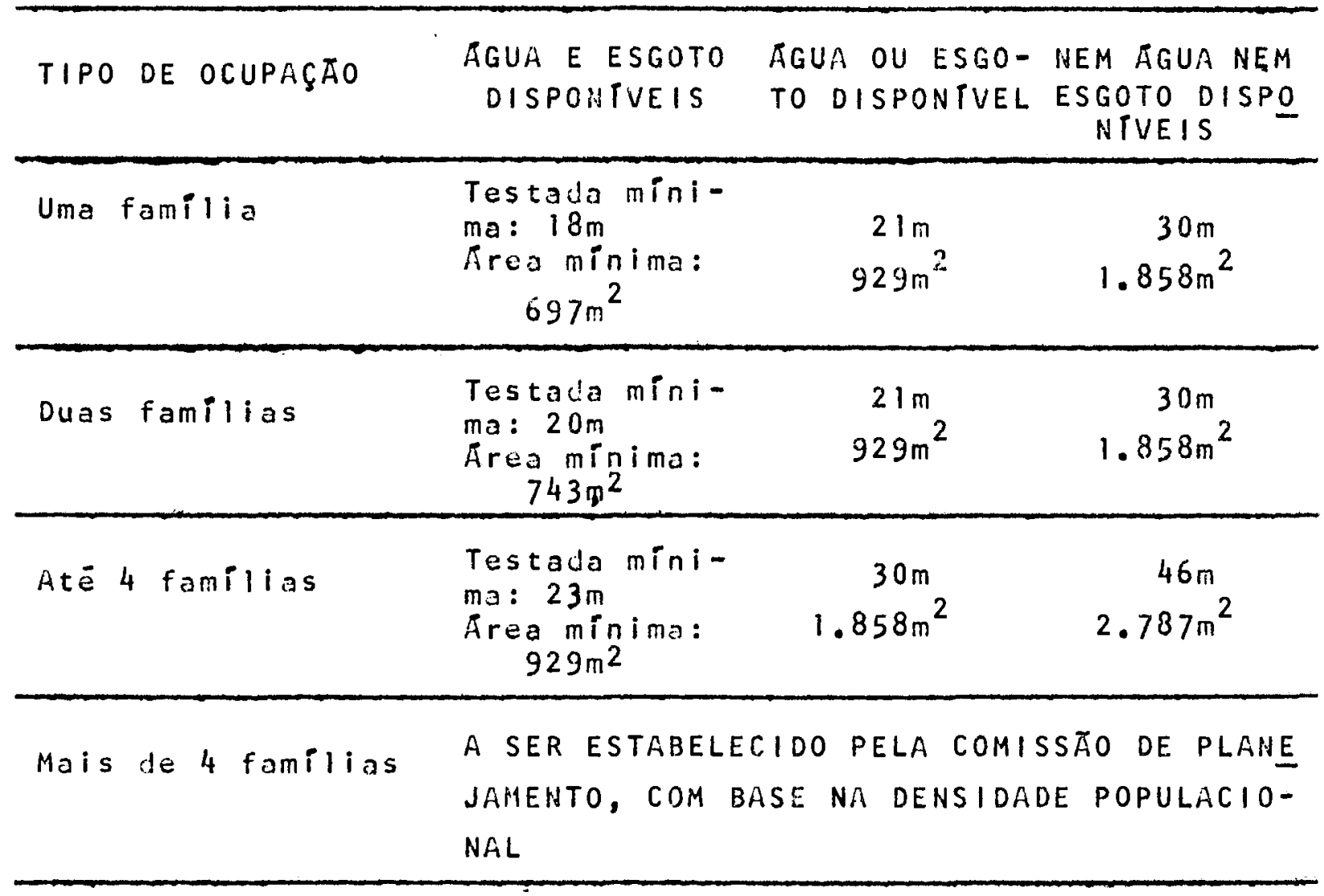

FONTE: VILLAGE OF CARLETON SUBDIVISION REGULATIONS 
QUADRO 5.7

Proposta para dimensōes mínimas e indices de ocupaçāo de lotes em funçāo da infra-estrutura sanitäria existente

USO RESIDENCIAL

\begin{tabular}{llll} 
INFRA-ESTRUTU ABSORÇAO & UNIDADES HABI DIMENSOES MTNIMAS (m) TNDICE DE \\
RA SANITARIA DO TERRE & TACIONAIS POR TESTADA PROFUNDIDA OCUPAÇÃO \\
LOTE & LOTE \\
\hline
\end{tabular}

Serviços de Unifamili Nentiuma restriçäo sob este as agua esgoto ar e Mul= pecto: Dimensces e ocupaçä disponívis tifamili- em função de outros parämetros ar urbanisticos

\begin{tabular}{|c|c|c|c|c|c|}
\hline \multirow{3}{*}{$\begin{array}{l}\text { Somente ser- } \\
\text { viço de ägua } \\
\text { disponível }\end{array}$} & $B O A$ & $\begin{array}{l}\text { Un if amiliar } \\
2 \text { a } 4 \\
5 \text { a } 3 \\
9 \text { a } 12 \\
\text { mais de } 12\end{array}$ & $\begin{array}{l}\quad 8 \\
15 \\
\\
28 \\
32 \\
\text { A critério de }\end{array}$ & $\begin{array}{l}25 \\
30 \\
32 \\
35 \\
\text { autor }\end{array}$ & $\begin{array}{c}0,50 \\
0,50 \\
0,50 \\
0,50 \\
\text {. competente }\end{array}$ \\
\hline & REGULAR & $\begin{array}{l}\text { Unifamiliar } \\
2 \text { a } 4 \\
5 \text { a } 8 \\
9 \text { a } 12 \\
\text { Mais de } 12 \\
\end{array}$ & $\begin{array}{r}10 \\
20 \\
30 \\
35 \\
\text { A critērio de } \\
\end{array}$ & $\begin{array}{l}25 \\
30 \\
32 \\
35 \\
\text { autor } \\
\end{array}$ & $\begin{array}{r}0,50 \\
0,50 \\
0,50 \\
0,50 \\
\text {.competente } \\
\end{array}$ \\
\hline & $B A \mid X A$ & $\begin{array}{l}\text { Uni familiar } \\
2 \text { a } 4 \\
5 \text { a } 8 \\
\text { mais de } 8\end{array}$ & $\begin{array}{l}15 \\
30 \\
\text { A critērio da } \\
\text { näo recomendäv }\end{array}$ & $\begin{array}{l}30 \\
35 \\
\text { autor } \\
\text { lel }\end{array}$ & $\begin{array}{c}0,50 \\
0,40 \\
\text {. competente }\end{array}$ \\
\hline \multirow{3}{*}{$\begin{array}{l}\text { Serviços de } \\
\text { ägua esgo } \\
\text { to não dispo } \\
\text { niveis }\end{array}$} & $B O A$ & $\begin{array}{l}\text { Unifamiliar } \\
2 \text { a } 4 \\
5 \text { a } 8 \\
9 \text { a } 12 \\
\text { mais de } 12\end{array}$ & $\begin{aligned} & 3 \\
& 15 \\
& 28 \\
& 32 \\
& \text { A critério de } \\
&\end{aligned}$ & $\begin{array}{l}40 \\
45 \\
45 \\
50 \\
\text { autor }\end{array}$ & $\begin{array}{r}0,40 \\
0,40 \\
0,40 \\
0,40 \\
\text { competente } \\
\end{array}$ \\
\hline & REGULAR & $\begin{array}{r}\text { Un i fami liar } \\
2 \text { a } 4 \\
5 \text { a } 8 \\
9 \text { a } 12 \\
\text { mais de } 12 \\
\end{array}$ & $\begin{array}{r}10 \\
20 \\
30 \\
\text { A critērio dá } \\
\text { Näo recomendäv } \\
\end{array}$ & $\begin{array}{l}40 \\
45 \\
45 \\
\text { autor } \\
\end{array}$ & $\begin{array}{r}0,40 \\
0,40 \\
0,40 \\
\text {. competente } \\
\end{array}$ \\
\hline & $B A \mid X A$ & $\begin{array}{l}\text { Unifamiliar } \\
2 \text { a } 4 \\
\text { mais de } 4\end{array}$ & $\begin{array}{l}15 \\
30 \\
\text { Năo recomendáv }\end{array}$ & $\begin{array}{l}45 \\
50 \\
1 \mathrm{el}\end{array}$ & $\begin{array}{l}0,33 \\
0,33\end{array}$ \\
\hline
\end{tabular}

OBS. ABSORÇAOO BOA: solo tipo areia fina (coeficiente de absorção en tre 90 e $1401 / \mathrm{m}^{2}$. dia)

ABSORÇĀO REGULAR: solo ti po areno-argiloso, com mais areja. (coe ficiente de absorção entre 50 e $901 / \mathrm{m}^{2}$. diaT

ABSORÇÃO BAIXA: solo com predominancia de argilo (coeficiente de absorção entr: 25 e $501 / \mathrm{m}^{2}$. dia) 


\section{QUADRO 5.8}

Proposta para dimensões mínimas e índice de ocupaçäo de lotes em função da infra-estrutura sanitäria existente

USO COHERCIAL

$\begin{array}{llllll}\text { INFRA-ESTRU- } & \text { ABSORÇÃO } & \text { NOMERO DE } & \text { DIMENSOEES HTNIMAS(m) } & \text { INDICE DE } \\ \text { TURA SANITA- } & \text { NO TERRE } & \text { PESSOAS E } & \text { TESTADA PROFUNDIDADE } & \text { OCUPAÇAOO } \\ \text { RIA } & \text { NO } & \text { OIFICAÇĀO } & & & \end{array}$

Serviço de àgua e esgo to disponitvel

Nenhuma restrição sob este aspecto. Dimensões e ocupação em função de outros parāmetros urbanísticos

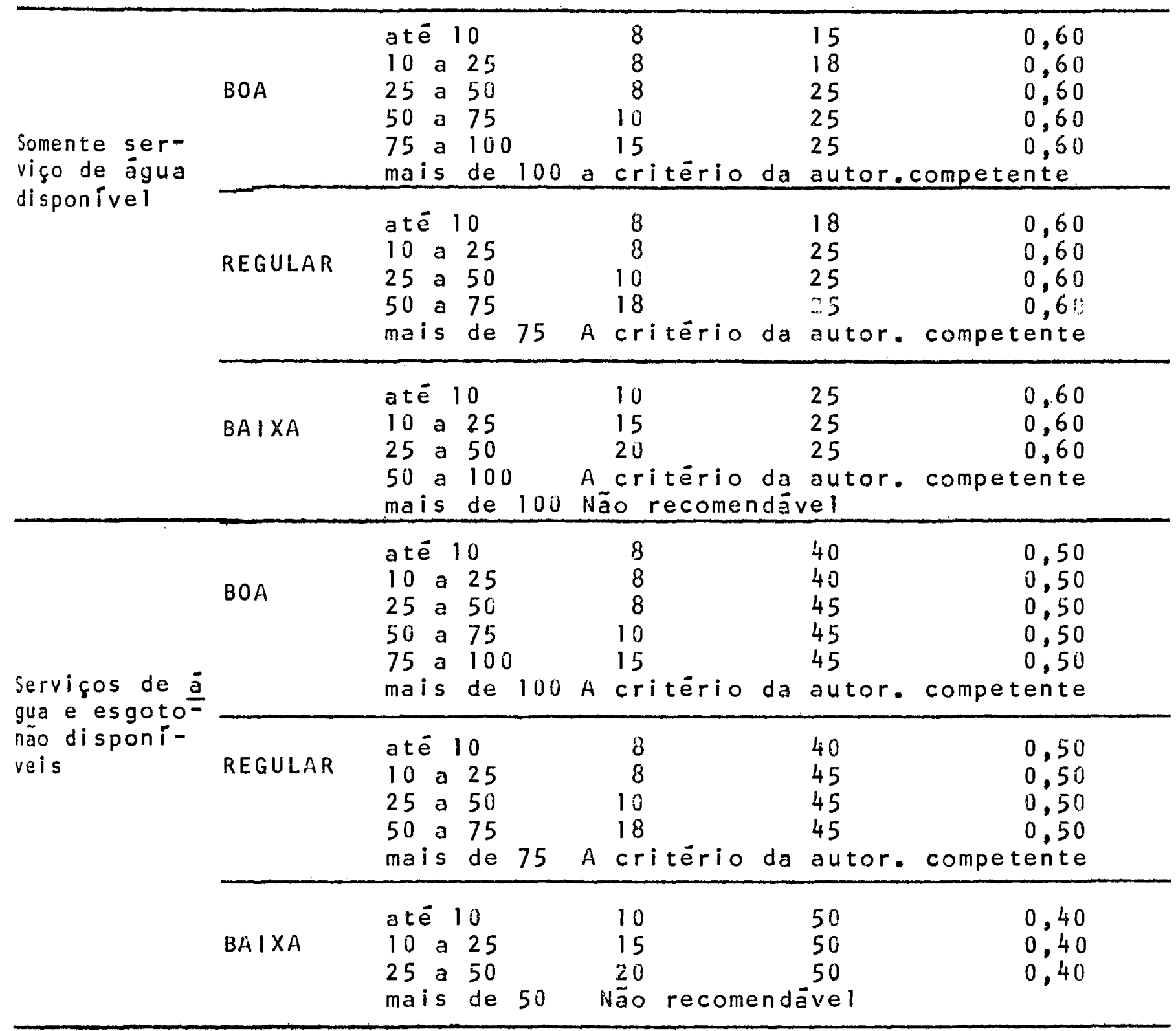

OBS. (1) Absorções BOA, REGULAR e BAIXA - ver observações do QUADRO.. 5.7

(2) Estas dimensões são aplicāveis às indūstrias leves, assim en tendidas as que dispöem de n:s. de operärios dentro dos limi tes apresentados neste Quadro e onde as äguas residuärias são provenientes apenas das instalaçöes sanitärias. 
- Para os sumidouros, considerou-se como ärea de absor ção somente as paredes lateriais do mesmo

- As valas de infiltração são recomendadas para terre nos com BAIXA absorção, ou quando o lençol freảtico é elevado. Neste caso, considerou-se como ārea de absor ção apenas o fundo da vala. 0 espaçamento mínimo on tre ramais dave ser de 1 metro

- Os sistemas de absorção devem estar afastados:

de poços - 30 metros (mínimo)

de edificações e limites do lote-3 metros (mi n i mo)

5.3.3 - Proteção de mananciais superficiais

A qualidade da àgua de reservatórios e de cursos d'ägua e seus afluentes depende diretamente do uso do solo na à rea onde se situam.

A produção de resíduos líquidos, a partir das ativida des humanas em uma ārea urbana, dependerá, basicamente, do tipo de uso do solo que ocorre na mesma. Assim, podem ser gerados: á guas residuārias domésticas e industriais; āguas de escoamento sobre a superfície do terreno; líquidos percolados a partir de residuos depositados no solo; àguas poluídas que se infiltram no terreno, entre outros.

Estes líquidos, alcançando coleções superficiais de ägua, podem causar a sua poluição, com reflexos sobre o homem e outras formas de vida.

o controle através do disciplinamento do uso do solo é bastante eficlente. Podemos orientar o uso-ocupaçāo das āreas marginais aos recursos hidricos superficiais, de forma a minimi zar a produção e deslocamento de líquidos poluídos.

Devemos ressaltar que o disciplinamento do uso do so 1o, sozinho, não é suficiente para garantir a qualidade da ägua superficial. Outras medidas devem ser aplicadas concomitantemen te, tais como a construção de sistemas coletores e de tratamento de esgotos domésticos e industriais.

No disciplinamento do uso do solo visando a preserva 
ção de recursos hídricos, deve-se sempre pensar em termos de ba cias hidrogräficas, jā que a qualidade do líquido de determina da coleção d'ägua dependerá dos seus tributários e, consequente mente, das ações desenvolvidas em toda a bacla.

o controle da poluição da ägua superficial deve con siderar dois tipos principais de fontes de poluição:

- Fontes localizadas de poluição da água

- Fontes não localizadas de poluição da água

5.3 .3 .1 - Controle de fontes não localizadas

As principais fontes não localizadas de poluição da gua são as äguas de infiltração e as āguas de escoamento super ficial ("runoff"). No item 4.3 .2 comentamos os diversos mecanis mos de ocorrência de poluição a partir destas fontes. Já mostra mos, tambēm, algumas medidas para controlar o acesso das águas de infiltração aos recursos hídricos subterrâneos. Estudaremos, agora, algumas medidas de controle da poluição de mananciais su perficiais de āgua por meio de äguas de infiltração e de escoa mento superficial.

Uma medida discutida anteriormente com relação à per colação de líquidos poluídos no solo foi o afastamento entre a fonte de poluição e a formação hídrica. Vimos que a distância entre o foco poluidor e a ägua constitui uma barreira efetiva ao deslocamento de poluentes, especialmente compostos orgânicos e patogênicos.

Com relação às äguas de escoamento superficial, são värias as providências a serem adotadas visando reduzir os seus efeitos:

- Diminuição da quantidade da āgua de escoamento

- Interceptação do líquido em escoamento

- Adoção de medidas para controle da erosão do solo

- Melhoria da limpeza das vias püblicas

- Adoção de faixas de preservação às märgens dos re cursos hidricos superficiais

o volume do "runoff" é função de värios fatores, jā comentados: quantidade e intensidade das chuvas; declividade do terreno; tipo de vegetação existente; pavimentação do solo; 
caracteristicas do terreno.

Assim, algumas medidas jä discutidas anteriormente com relação ao controle da erosão do solo são também válidas no sentido de evitar um grande volume de ägua de escoamento superfi cial:

- cobertura vegetal adequada

- preservação do escoamento natural das águas

- disciplinamento do uso do solo, principalmente em terrenos com gtande declive

Algumas vezes, é necessäria a utilização de dispositi vos para reter, temporäria ou permanentemente, o líquido escoa do. Estes, podem constar de:

- Construção de valetas ou diques para desvio das ā guas

- Execução de "bacias de sedimentação", para acumular a àgua durante certo tempo, reduzindo a quantidade de poluentes e controlando a velocidade do fluxo de escoamento

- Acumulação da ãgua em reservatórios, podendo o 1 í quido ser utilizado para usos recreacionais, paisa gísticos, em irrigação, em combate a incêndios,etc.

As faixas de proteção constituem uma eficiente medida de preservação dos recursos hídricos superficiais. Quando adequa damente tratadas, formam uma efetiva barreira ao deslocamento de poluentes no solo, bem como àreas propícias à infiltração da à gua e consequente diminuição do volume do "runoff".

As faixas de proteção são äreas situadas às märgens de coleções de ägua, as quais são preservadas atravēs de um dis ciplinamento rigoroso do uso do solo.

obviamente, as faixas de proteção não consti tuem uma medida de eficiencia total. Mesmo com a sua existência, líquidos escoando no sub-solo ou superficialmente alcançarão as coleções de àgua, carreando poluentes. Já dissemos que o solo funciona co mo elemento "purificador" da ăgua, principalmente para compostos orgānicos e para patogênicos. Porém, muitos poluentes químicos conseguem percorrer grandes distāncias, invalidando as faixas de proteção, nestes casos. 
No entanto, devemos considerar muitas vantagens para as faixas. Alēm do aspecto de isolamento sanitärio, as äreas pre servadas às márgens de coleções superficiais de ăgua apresentam as seguintes utilidade:

- Protegem äreas adjacentes da ocorréncia de cheías

- Constituem medida de controle da erosão

- Proporcioñam a ṕreservação da vegetação existente, garantindo a proteção da fäuna e flora típicas. As àrvores, às márgeris do coleçöes de ägua, côntribuem para o sombreamento e a consequerte manutenção da temperatura adequada à fauna aquātica

- Podem constituir áreas para recreação, ou de preser vação paisagística e ecolögica

- Asseguram o escoamento adequado das águas pluviais, garantindo a drenagem das mesmas.

Embora a faixa de proteção não elimine totalmente os poluentes, podemos dizer que ela atenua os seus efeitos sobre os recursos hídricos. Esta eficiência pode ainda ser maior se, além da faixa de proteçāo, for feito um disciplinamento do uso do so lo nas äreas vizinhas à mesma.

A adoção de faixas como medida de preservação de re cursos naturais foi primeiramente estudada no Brasil por UBALDO CARPIGIANI. Ele recomenda a adoção de uma "faixa sanitāria" de proteção com largura mínima de 50 metros, a partir da cota mäxi ma de inundação dos recursos hídricos em geral, na qual serä dís ciplinado o uso do solo, não sendo permitidas atividades que re sultem em poluição. (13)

Nos Estados Unidos da Amërica, existem recomendaçōes para faixas de proteção com largura variável de 7,6 a 91 metros (25 a 300 pés). Por exemplo, o Condado de Napa, Califörnia, exi ge uma ärea de proteção com 15 metros (50 pés), em cada lado do curso d'ägua. No Condado de Orange, Nova York, esta faixa tem 61 metros $(200$ pés). No Condado de Oakland, Michigan, a largura re comendada è de 7,6 metros (25 pés). Jä as cidades de Marlborough e Brooklyn, Connecticut, estabelecem uma faixa de proteção de 46 metros (150 pës). O Estado de Wiscousin adota uma faixa com lar gura mínima de 91 metros (300 pés), variāvel com a ārea de inun dação. (48) 
SAMUEL BRANCO e ARISTIDES ROCHA, sugerem "como largu ra mínima a ser estabelecida para as faixas de segurança sanitá ria em torno de reservatórios de acumulação de àguas potáveis, $30 \mathrm{~m}$, largura essa medida em projeção e tal que, nessa faixa, se jam criadas condiçōes desfavoráveis ao transporte de materiais por meio de rolamento". Além da faixa, os autores sugerem o zo neamento das atividades que se desenvolverāo na bacia hidrogräfi ca, o repetido levantamento das condiçōes sanitärias dos tributä rios e a fiscalização permanente dos focos potenciais de polui ção. (10)

Com o objetivo de preservar a vegetaçäo, o Cödigo flo restal Brasileiro - Lei n: 4771, de 15 de setembro de 1965 - con sidera de preservação permanente as florestas e demais formas de vegetação natural situadas:

(a) ao longo dos rios ou de outro qualquer curso d'a gua, em faixa marginal cuja largura mínima será:

- de 5 metros, para os rios de menos de 10 metros de largura

- igual à metade da largura dos cursos que mecam de 10 a 200 metros de distāncia entre as mār gens

- de 100 metros, para todos os cursos cuja largu ra seja superior a 200 metros

(b) ao redor das lagoas, lagos ou reservatórios de á gua naturais ou artificiais.

(c) nas nascentes, mesmo nos chamado "olhos d'água", seja qual for a sua situação topogräfica.

Estas faixas, mesmo visando preservar a vegetação, po dem ser utilizadas como parte integrante de um planejamento vi sando a proteção sanitária dos recursos hídricos.

Achamos que a melhor faixa de proteção è aquela defí da após levantamento minucioso das características do reservató rio ou curso d'ägua, como tambēm das suas äreas marginais. 0 es tabelecimento de uma faixa com largura fixa pode excluir de pre servação muitas äreas de importāncia ecológica ou paisagística situadas junto à água. Por exemplo, āreas alagadas (pântanos),zo nas de recarga de aquíferos, terrenos com grande declive, äreas 
com problemas de drenagem, ou zonas de vegetação densa, muitas vezes precisam ser preservadas, ficando fora de uma faixa de lar gura fixa pre-determinada.

Por outro lado, reconhecemos que, nem sempre, os mun $\underline{i}$ cípios dispōem de meios para efetuar todos os levantamentos ne cessários à definiçäo das āreas a preservar. Nestes casos, uma faixa com largura prë-fixada è bastante välida, pois garantira uma preservaçāo da qualidade da àgua.

Temos, assim, duas opções para o estabelecimento de faixas de proteção de coleções superficiais de ägua:

(1) Faixa com largura fixa, a partir do nível mäximo da àgua.

(2) Faixa com largura variävel, ajustando-se às carac teríşitcas das āreas adjacentes. Em alguns tre chos terà uma largura prē-determinada e em outras se adaptarä às äreas a serem preservadas.

Na FIGURA 5.6, mostramos como seriam as faixas de pro teção, nos dols casos.

Em ambas as situaçōes, devem ser definidos:

- Largura mínima da faixa de proteção

- Uso do solo na faixa

- Uso do solo nas āreas adjacentes à faixa

- Uso do solo nas demaís äreas da bacia hidrogräfica

A definição da largura mínima da faixa deve ser fun ção das características do meio, conforme jā comentado. Podemos, no entanto, com base nas consideraçöes feitas até aqui, apresen tar sugestöes para a fixação desta largura.

Consideremos duas situaçöes:

(1) Trecho situado em ärea servida por redes püblicas de ägua e esgoto.

Neste caso, a faixa deverá ter largura mínima de acordo com o disposto no cädigo florestal ou serä funçāo de exigèncias relativas à drenagem das äguas pluviais.

(2) Trecho năo dispondo de sistema coletar de esgoto. - Cursos d'água com largura até 60 metros:faixa 


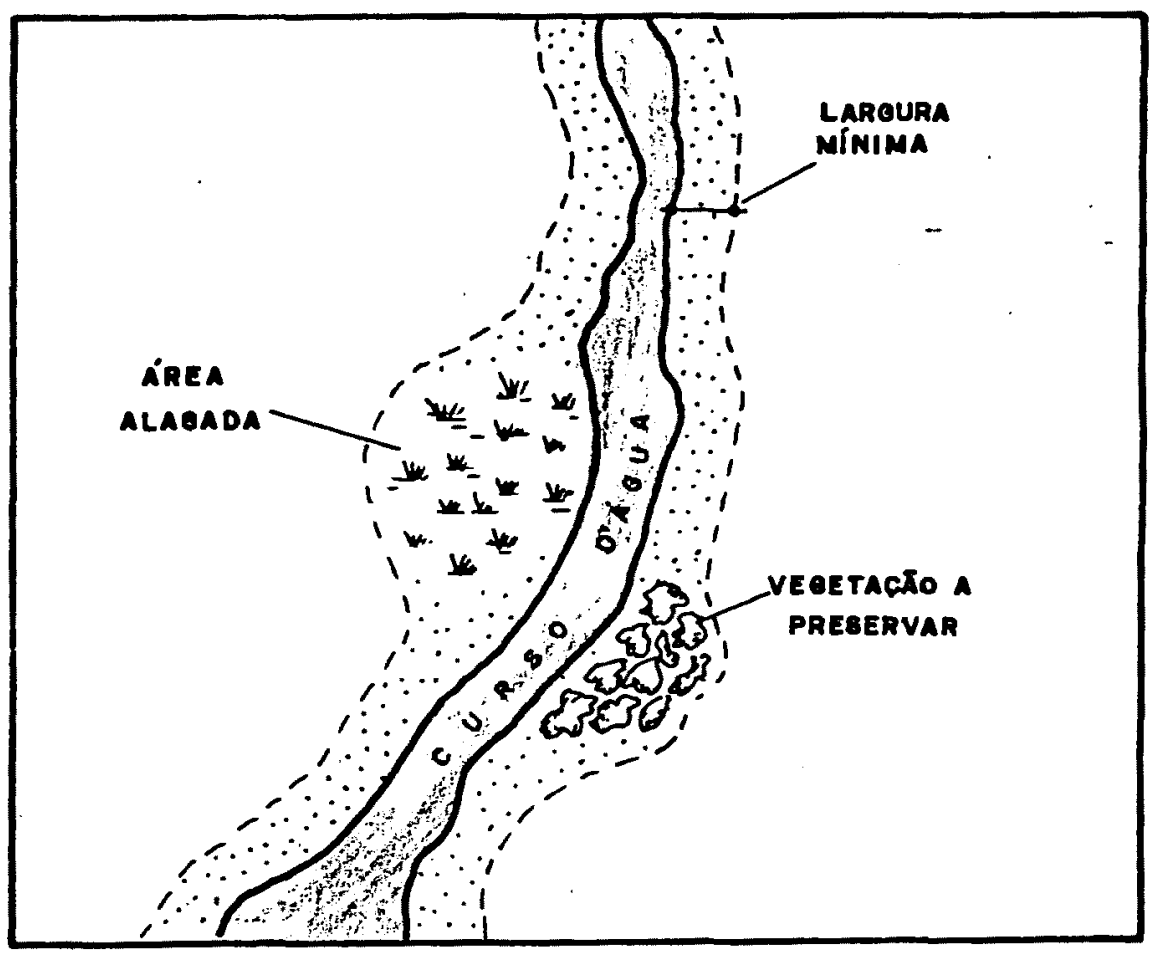

- faIXa com laroura variável

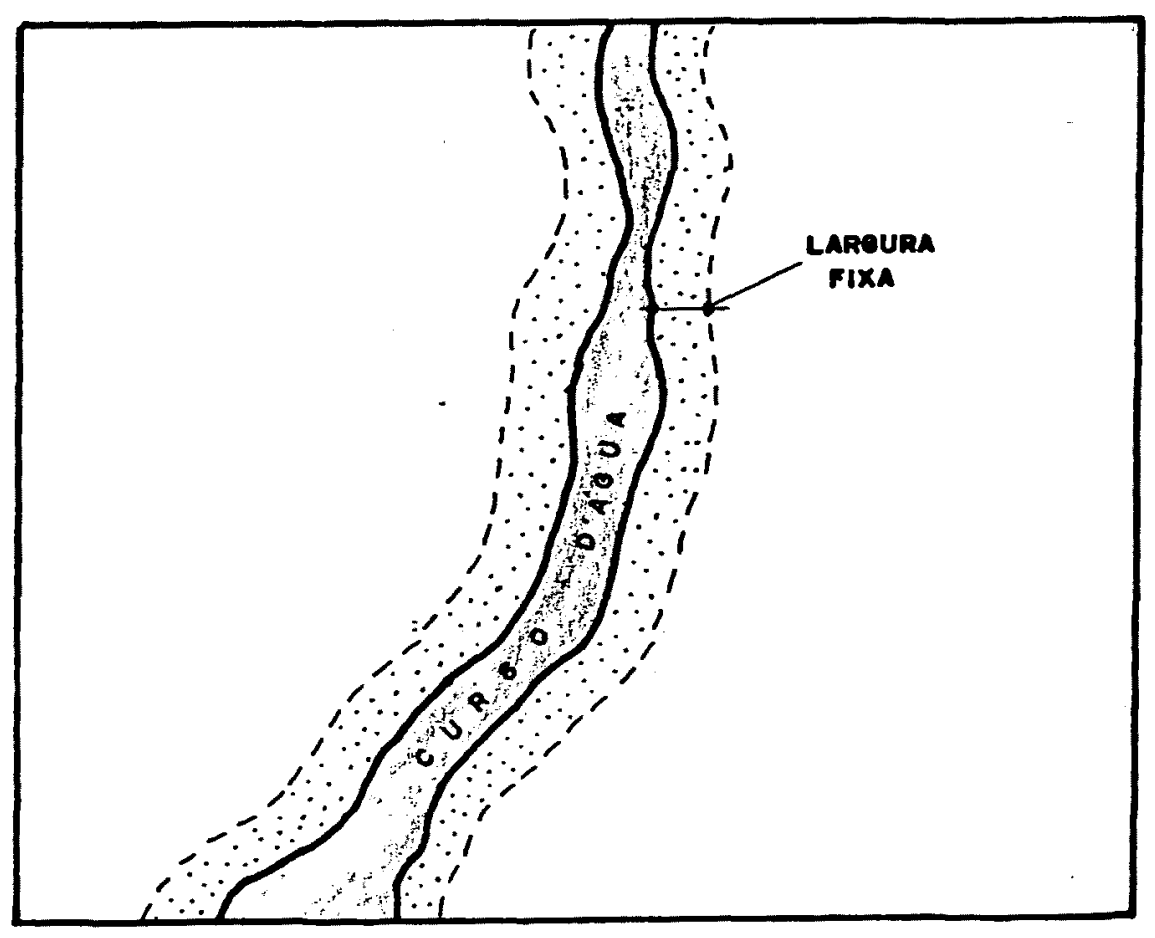

FAIXA DE LARGURA FIXA

meuna 3.0

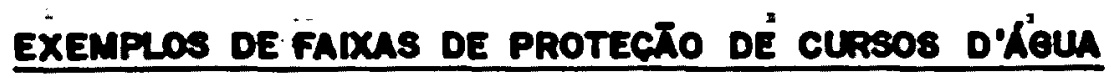

BRT?.

Formato A4 
de proteção com, no mínimo, 30 metros de largura

- Cursos d'ägua com largura superior a 60 metros: faixa de proteção com largura de acordo com o có digo florestal (igual à metade da largura dos cur sos d'água, atē um măximo de 100 metros).

- Reservatórios superficiais de ägua: faixa de pro teção variando de 30 a 100 metros, em função do volume de armazenamento de ägua e das características do ambiente adjacente.

Quando as necessidades de drenagem de äguas pluviais exigirem, estas faixas poderão ser aumentadas para atender a ca da caso específico.

Na faixa de proteção devem ser mantidas, ao māximo, as condiçōes naturais, não sendo recomendados usos que provoquem alteraçōes das mesmas. Somente devem ser permitidos usos tais co mo:

- atividades recreacionais que não necessitem de maio res instalaçöes ou desmatamento: pesca; excursionis mo; natação; esportes näuticos; outros esportes ao ar livre

- exploração agrícola, sem provocar grandes modifica ções no ambiente natural e sem utilizar defensivos agricolas ou fertilizantes

- estruturas de controle da erosão e do escoamento sü perficial da água

- práticas conservacionistas ou de experiências ecolö gicas.

Deverá ficar sob rigoroso controle a realização, den tro desta ārea, de atividades que envolvam: depōsito ou remoçäo de materiais; escavações; alterações na topografia; plantação ou remoção de vegetação.

Nos mananciais destinados ao abastecimento público, recomendamos a desapropriação da ärea constituída pela faixa de proteção, para garantia de melhor controle do uso do solo.

Nos demais mananciais, quando näo interessar a desa propriação, deveră ser disciplinado o uso do solo, conforme já 
comentado. Estas āreas poderäo ser computadas como āreas livres, fazendo parte das àreas exigidas para permanecerem não ocupadas, quando da aprovação de loteamentos.

Deve ser definido, também, o uso-ocupaçāo do solo nas àreas adjacentes à faixa de proteção, bem como na bacia como um todo.

Nas äreas adjacentes à faixa, poderāo ser permitidos usos tais como, residencial, comercial e de serviços, recreativo, industrial, ou outros, desde que sejam garantidas as seguintes condi ções:

- Coleta de esgoto atravēs de sistema püblico ou por meio de soluções individuais, desde que satisfeitas todas as condições relativas a execução adequada de fossas, conforme comentado no item 5.3.2.

- Destinação final dos resíduos sólidos fora destas a reas.

- A utilização de fertilizantes e defensivos agríco las deve ser rigorosamente controlada pelo órgão competente.

- Devem ser estabelecidas dimensões mínimas e taxas de ocupação māxima dos lotes, de modo a garantir ex tensas āreas sem impermeabilização, reduzindo o es coamento superficial da ägua.

Nas āreas adjacentes às faixas de proteção devem ser evitadas ao máximo a impermeabilização das vias públicas, deven do isto ocorrer somente em trechos estritamente indispensáveis à circulação de veículos.

vias de circulação de veículos junto à faixas de pro teção devem ser evitadas, pois isto pode gerar, no futuro,estrei tamentos das faixas, para garantir alargamentos das pistas. 0 acesso à faixa de proteçāo deve ser feito atravēs de vias para pedestres.

Recomendamos a adoção de duas faixas de controle, ad jacentes à faixa de proteção:

- Na primeira faixa, correspondente à primeira qua dra, e com largura mínima de 100 metros, recomendase a adoção de lotes com ārea não inferior a 1.000 
metros quadrados. A taxa de ócupação deverá ser de; no māximo, $30 \%$.

- Na segunda faixa, correspondente às duas quadras se guintes à primeira, com largura minima de 200 me tros, recomenda-se a adoção de lotes com ärea não inferior a 500 metros quadrados. A taxa de ocupaçāo deverả ser de, no mäximo, $50 \%$.

Nas duas faixas de controle, as äreas dos lotes ocupa das por construções deverão permanecer sem impermeabilização.

Na FIGURA 5.7, apresentamos um esquema mostrando a distribuiçäo das faixas onde deverá ser disciplinado o uso do so lo visando a preservação dos recursos hídricos.

0 desenho da fIGURA 5.8 mostra um exemplo de distri buição de lotes e vias de circulação, em āreas marginais às co leções superficiais da àgua.

5.3.3.2 - Controle de fontes localizadas

As principais fontes localizadas de poluição da ägua superficial são os langamentos de esgotos domésticos e industri ais.

o planejamento do uso do solo pode contribuir para a tenuar este problema disciplinando os locais para lançamento das àguas residuárias provenientes da rede de esgotos domésticos ou das indüstrias. A localização dos pontos de lançamento de efluen tes de estações de tratamento, quando adequadamente escolhida, pode minimizar os efeitos da poluigão sobre as atividades huma nas nas cidades.

A definição de locais para lançamento de efluentes de estaçōes de tratamento de esgoto depende de vários fatores:

(1) Situação atual e desejada para os recursos hídri cos da bacia hidrogräfica. Usos previstos para os mesmos.

(2) Volume e características dos despejos (estimativa da carga poluidora)

(3) Conhecimento dos parâmetros que influem no proces 


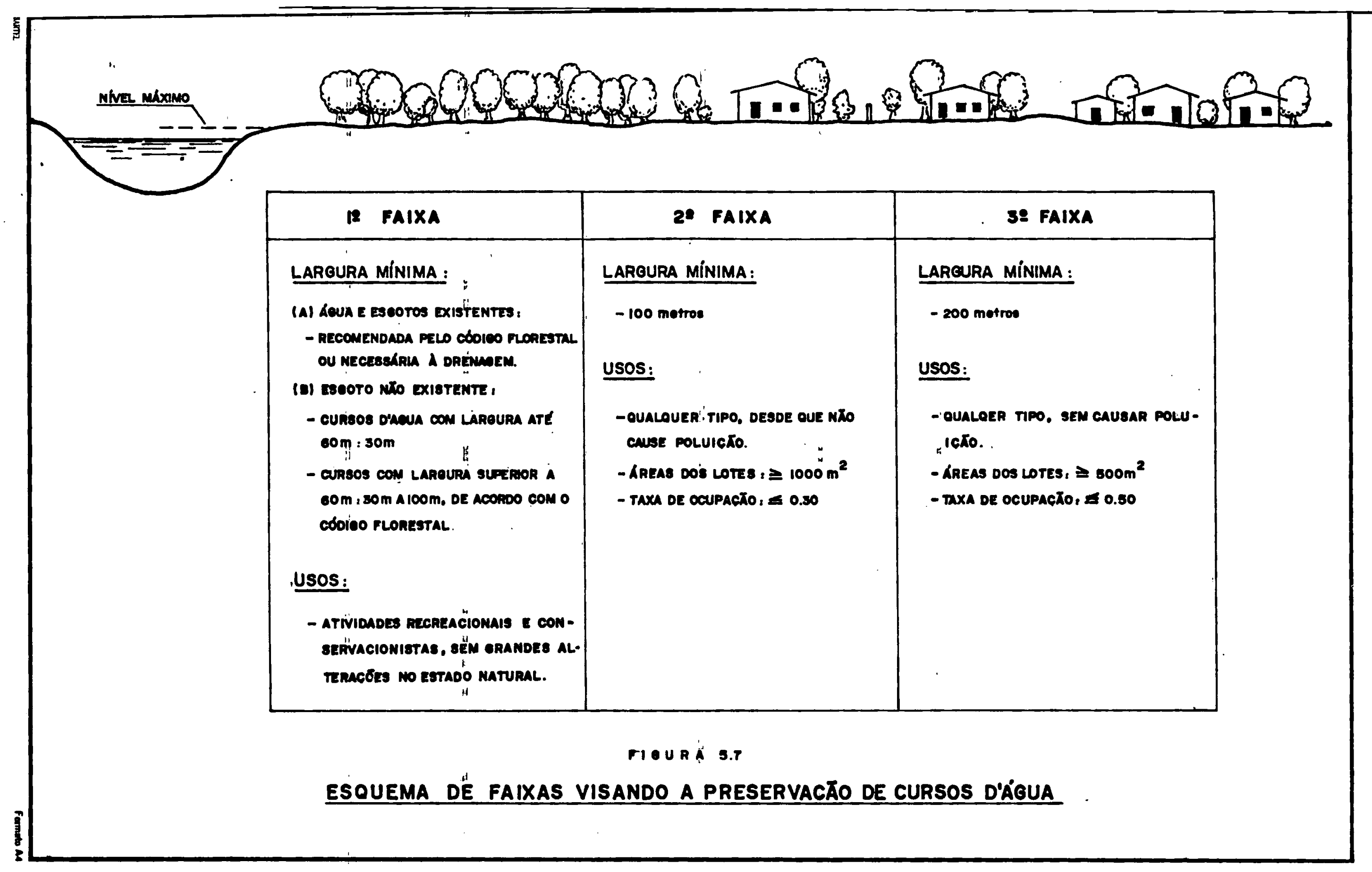




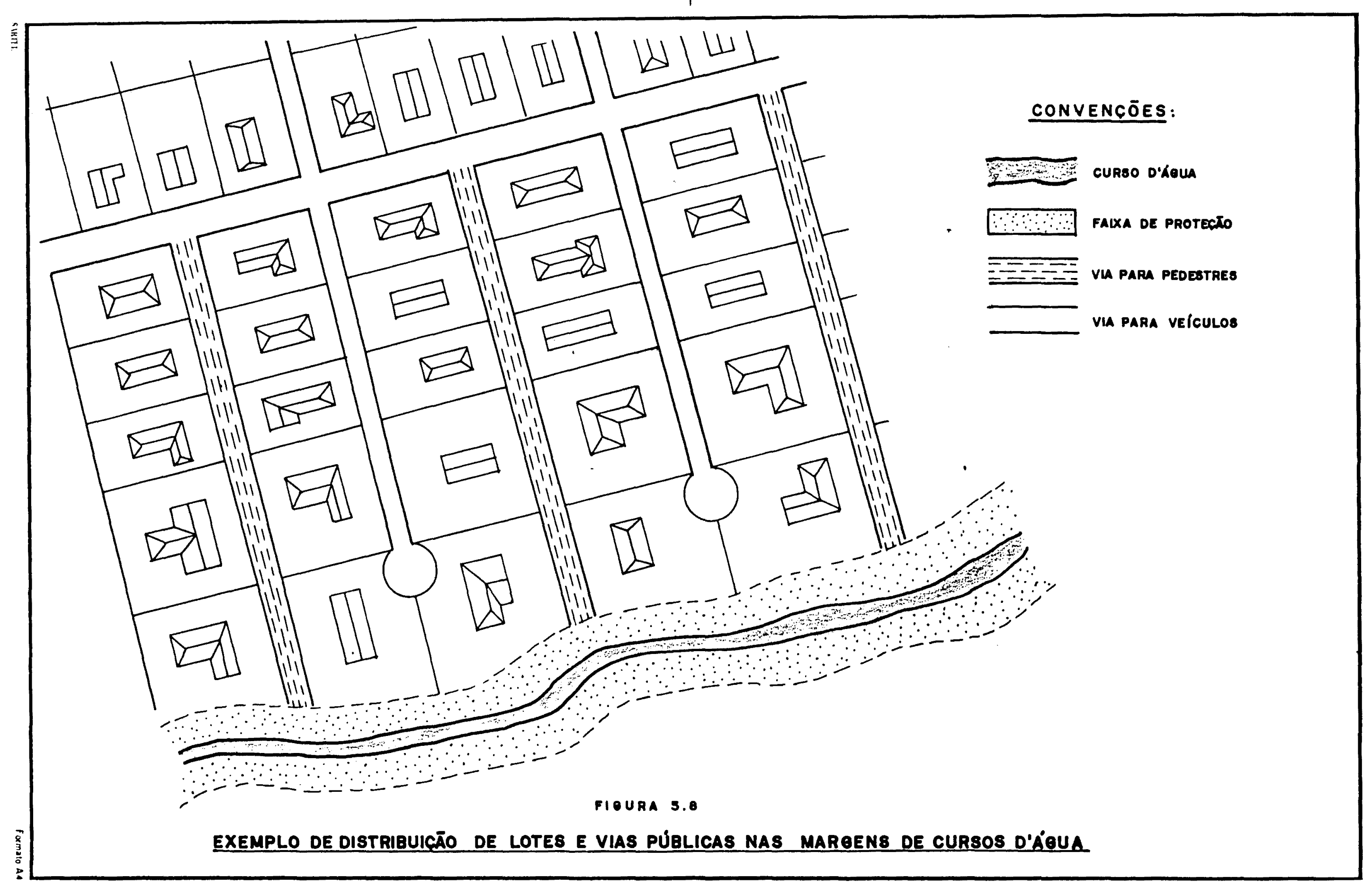


so de auto-depuração da ägua: volume do corpo re ceptor; condições de escoamento; oxigènio dissol vido; poluentes existentes.

(4) Posicionamento em relação à ärea urbanizada, ao ló cal de captação da água para abastecimento e às outras comuhldades.

os recursos hídrlcos de uma bacia hidrográfica devem ser classificados em funçăo dos usos a que se destinami Devido à multiplicidade de aproveitamento da ägua e a existência de $\underline{u}$ sos conflitantes para um mesmo manancial, é importante que seja feita, antes de tudo, uma classificação dos recursos, definindo usos preponderantes para as äguas.

Através da Portaria n? 0013 , de 15 de agosto de 1976, - Ministério do Interior estabeleceu a seguinte classificação das àguas interiores do Territōrio Nacional:

Classe 1 - āguas destinadas a:

ao abastecimento doméstico, sem prëvia ou com simples desinfecção

Classe 2 - äguas destinadas a:

a) ao abastecimento doméstico, após tratamento convencional

b) à irrigação de hortaliças ou plantas frutífe ras

c) à recreação de contato primärio (natação, es qui aquático e mergulho)

Classe 3 - àguas destinadas a:

a) ao abastecimento domëstico, após tratamento convencional

b) à preservação de peixes em geral e de outros elementos da fauna e da flora

c) à dessedentaçāo de animais

Classe 4 - äguas destinadas a:

a) ao abastecimento doméstico, após tratamento avançado

b) à navegação 
c) à harmonia paisagística

d) ao abastecimento industrial, irrigação e a $\underline{\underline{u}}$ sos menos exigentes,

Nas äguas de Classe 1 , näo sāo tolerados lançamentos de efluentes, mesmo tratados. Nas āguas das demais classes,è per mitido o lançamento de efluentes, desde que obedeçam às condi çōes definidas na Portaria, como tambēm garantam os limites e condiçōes fixados para as äguas de cada classe.

Para cada classe são definidas condiçōes e teores má ximos de substancias prejudiciais, tais como: materiais flutuan tes; óleos e graxas; sabor e odor; nümero de coliformes; DBO; oxi gênio dissolvido; compostos químicos. (35)

Assim, o lançamento de esgotos domésticos e industri ais, mesmo tratados, só poderä ser feito em determinado mananci al de ägua se não provocar alterações de modo a contrariar as condiçoes e limites estabelecidos para a Classe definida para o mesmo.

Entendemos que no meio urbano os recursos hídricos so mente deverāo ser classificados como de Classe 1 ou de Classe 2.

A carga poluidora de esgotos domêsticos pode ser ava liada com base no nümero de contribuintes. A composição destes resíduos é mais ou menos conhecida, podendo se estimar o potenci al de poluiçăo a partir da contribuição "per capita".

Em termos de carga de DBO, a contribuição "per capí ta" $\bar{e}$ da ordem de $54 \mathrm{~g}$ de DBO por habitante por dia.

Para os despejos industriais, existem mëtodos de ava liação da carga poluidora, a partir de informaçōes sobre o pro cesso industrial. (31)

Muitos resíduos líquidos industriais jä foram analisa dos, conhecendo-se as características dos principais. No QUADRO 5.9, relacionamos as caracterísitcas dos principais resíduos lí quidos industriais, servindo como indicação das indūstrias que merecerāo maiores cuidados quando da sua localização.

Uma forma de estimar a carga poluidora de uma indús tria, em termos de Demanda Bioquímica de oxigênio, é calcular a população que produziria um volume de esgoto com DBo equivalente ao do esgoto industrial.

Este é o chamado "equivalente populacional", cujos va 
lores para algumas indūstrias estão indicados no QUADRO 5.10. Exemplificando, podemos dizer que uma fäbrica de pạ pel produzindo l tonelada por dia, teria uma carga poluidora, em termos de DBO, equivalente à de uma comunidade com 100 a 300 pes soas.

Os QUADROS 5.9 e 5.10 são üteis ao planejamento urba no, como indicadores das indústrias mais poluidoras, as quais de verāo ser cuidadosamente localizadas na ärea urbana. E claro que para outras definiçōes, tais como sobre o tipo e eficiēncia do tratamento a ser aplicado, os resíduos líquidos de cada indústri a deverão ser detalhadamente estudados.

A escolha do corpo receptor de efluentes, e,portanto, a localização das estações depuradoras de esgotos domésticos da cidade, assim como o posicionamento de indústrias poluidoras e suas respectivas instalações de tratamento de resíduos líquidos, devem considerar, também, a capacidade de auto-depuração do ma nancial. Vários fatores influem neste processo, e devem ser devi damente analisados: volume de ägua; condiçōes de re-oxigenação; situação em termos de poluentes jā existentes.

E importante considerar o posicionamento dos locais de lançamento de efluentes tratado, em relaçāo à cidade,procuran do-se preservar os mananciais de captação de àgua para abasteci mento público, de usos recreacionais ou outros.

Considerando, por exemplo, que a àgua de um mesmo rio que atravessa uma cidade é usada para abastecer a população e pa ra receber os seus resíduos líquidos, è claro que os locais de lançamento de esgotos devem situar-se a jusante do ponto de cap tação da água.

Num planejamento regional, devem ser analisados os feitos de lançamento de esgotos de uma cidade sobre a qualidade da ăgua a ser utilizada por cidades situadas a jusante.

Pelo que foi exposto atè aqui, podemos ver como è im portante considerar-se a bacia hidrogräfica com um todo, classi ficando-se os recursos hídricos constituintes em função dos usos preponderantes para, a partir dai, serem definidos a localização das estações de tratamento e dos respectivos lançamentos finais de esgotos domésticos e/ou industriais. Esta análise permitirä a escolha de äreas para a localização de zonas industriais, em função do potencial poluidor de seus resíduos líquidos. 
QUADRO 5.9

Características dos principais resíduos líquidos industriais

ENGENHOS DE AÇUCAR

a) Aguas das colunas baromêtricas:qualidade depende das condições técnicas dos evaporadores e inta lizadores. Podem apresentar DBO da órdem de $1.000 \mathrm{mg} / 1$ ou mais.

b) Melaço: - grande quantidade deproteínas

- fibras e outras cēlu las vegetais

- cor pardacenta

c) Resíduos da filtração:- sölidos

DESTILARIAS DE AGUARDEN

TE E ALCOOL
- cor castanha esverdeada

- grande turbidez

- pH baixo (cerca de 4)

- poucos sölidos sedimentáveis

- DBO superior a $7.000 \mathrm{mg} / 1$

- grande quantidade de substānciasorgânicas, sujeitas a fermentaçäo

- teor de enxófre elevado

- facilmente putrecível, com odor de gás sulfídrico

- äcido sulfürico

- aspecto desagradavel

- cheiro forte

- pH elevado, podendo ultrapassar 1 unidades

FABRICAS DE CELULOSE

- grande quantidade de sölidos sedi mentäveis

- sabões, breu, mercāptans, tereben tina

- ácido cianídrico

- quantidade considerável de sōli dos sedimentäveis

FECULARIAS DE MANDIOCA

- aspecto esbranquiçado, às vezes marron

- elevada turbidez, atē $3.000 \mathrm{mg} / 1$ de $\mathrm{SiO}_{2}$

- cheiro, às vezes, äcido

a) Despejos das maltarias

- turbidez e cor não muito eleva das

CERVEJARIA

- gräos de cevada em suspensão

- sólidos sedimentäveis

- DBO varia de 400 a $1500 \mathrm{mg} / 1$ 
QUADRO 5.9 (continuação)

\begin{tabular}{|c|c|c|}
\hline CERVEJARIAS & b) & $\begin{array}{l}\text { Despejos da cervejaria propriamen } \\
\text { te dita: } \\
\text { - restos de rótulos das garrafas } \\
\text { - amido } \\
\text { - restos de lúpulo cozido } \\
\text { - fermento } \\
\text { - DBO entre } 1.000 \text { a } 2.000 \mathrm{mg} / 1\end{array}$ \\
\hline$F A B R \mid C A S$ & PAPEL & $\begin{array}{l}\text { - fibras finas (sölidos em suspen- } \\
\text { são) } \\
\text { - amido } \\
\text { - caulim } \\
\text { - sabão de breu } \\
\text { - corantes } \\
\text { - DBo baixa, com exceção do papel } \\
\text { feito com material catado do li } \\
\text { xo }\end{array}$ \\
\hline
\end{tabular}

a) Åguas de lavagem de lãs: .

- lanolina

- sólidos em suspensão

- alcalinidade

b) Beneficiamento inicial do algodão:

- ácidos orgânicos

\section{INDUSTRIAS TEXTEIS}

(Flaçōes, tecelagem, tin turarias, estamparias)
- ceras, resinas

- amido

- glúten

- ácidos e älcalis

c) Alvejamento:

- águas residuárias alcalinas:cor castanha escura, com cheiro de lixívia

- äguas de cloreção: brancas lei tosas, com grande guantidade de sólidos em suspensao

- ãguas de lavagem ácida: são tur vas e esbranquiçadas e têm $\mathrm{pH}^{-}$ bai xo

d) Tingimento:

- fibras

- corantes

- mordentes

- sais metálicos

- tanino

- sabões

- àguas fortemente alcalinas

- saböes e öleos

EXTRAÇĀO DE OLEOS

- restos de células vegetais

- matéria proteica

- corantes vegetais fosfotados

- resinas 


\begin{tabular}{|c|c|}
\hline CURTUMES & $\begin{array}{l}\text { - presença de sulfureto de sôdlo e } \\
\text { cal } \\
\text { - sólidos sedimentäveis } \\
\text { - presença de cromo (töxico) } \\
\text { - presença de tanino (coloração ne } \\
\text { gra) } \\
\text { - em suspensão: tecido muscular, so } \\
\text { ro de sangue, restos de pele, se } \\
\text { - bo e pelos } \\
\text { - DBO de } 1000 \text { a } 1.500 \mathrm{mg} / 1\end{array}$ \\
\hline
\end{tabular}

- teor elevado de sōlidos em suspen são e sedimentáveis

MATADOUROS E - nitrogênio orgânico

- DBO de 300 a $32.000 \mathrm{mg} / 1$

FRIGORTFICOS

- altamente putresciveis (mau cheiro)

- contêm sangue, gorduras, fragmen tos de ossos

- aspecto avermelhado

- micro organismos patogênicos (quan do são abatidos animais doentes)

- DBO: de 500 a $2.000 \mathrm{mg} / 1$,quando há recuperação do soro

até $3.000 \mathrm{mg} / 1$, quando não hā recuperação do soro

LATICTNIOS

- entram rapidamente en decomposição

- soro (nas indústrias de prepara çäo de manteiga e queijo): contēm grande quantidade de matéria ni trogenada, gordura, lactose e sais minerais

ELETRODEPOSIÇOES DE ME TAIS (GALVANOPLASTIA) E DECAPAGEM DE SUPERFTCI ES NETALICAS
- presença de metais tóxicos: cromo hexavalente, cádmio e outros

- presença de ànions tóxicos: ciane tos, suifuretos, fluoretos, croma tos

- acidez elou alcalinidade pronunciadas

- óleo livre ou emulsionado

- äguas de lavagem:

REFINARIAS DE PETRO LEO

sal inas contêm fenóis, cianetos, mercāptãs

- condensados de destilação: áci dos orgânicos gãs sulfídrico mercāptãs 
QUALRO 5.9 (continuação)

\begin{tabular}{|c|c|}
\hline & $\begin{array}{l}\text { - refinação da gasolina: } \\
\text { fenóis e ácidos aromáticos } \\
\text { ácido sulfúrico ou soda cáusti } \\
\text { ca } \\
\text { - refinação dos óleos lubrificantes } \\
\text { furfurol } \\
\text { acetona } \\
\text { hidrocarbonetos clorados } \\
\text { óleos emulsionados } \\
\text { resinas } \\
\text { - outros produtos quínicos postem - } \\
\text { ser encontrados, resultantes de } \\
\text { tratamentos especiais }\end{array}$ \\
\hline $\begin{array}{l}\text { COQUEIFICAÇÃO DA HULHA } \\
\text { E USINAS DE GASS }\end{array}$ & $\begin{array}{l}\text { - fenóis } \\
\text { - cianetos } \\
\text { - amônia } \\
\text { - tiocianatos } \\
\text { - DBO de } 60 \text { a } 1.000 \mathrm{mg} / 1\end{array}$ \\
\hline
\end{tabular}

OBS: INFORMAÇÕES COMPILADAS DE AZEVEDO HETO \& LOTHAR HESS. (6) 


\section{QUADRO 5.10}

Tabela de equivalentes populacionais para diferentes tipos de indústrias

TIPO DE INDUSTRIA

QUANTIDADE DIARIA

EQUIVALENTES

POPULACIONAIS

\begin{tabular}{|c|c|c|c|}
\hline Laticínios sem queijaria & por 1.0001 lelte & 30 & -80 \\
\hline Laticínios com queijaria & por 1.0001 leite & 100 & -250 \\
\hline \multirow[t]{3}{*}{ Matadouro } & por 1 rez & 70 & -200 \\
\hline & por 2,5 porcos & 70 & -200 \\
\hline & por $1 \mathrm{t}$ de peso em pē & 150 & -450 \\
\hline Granja de galinhas & por l ave & 0,13 & $-0,25$ \\
\hline Silo para raçōes & por 1 t de ração diäria & 4 & -12 \\
\hline Usina de açucar & por $1 \mathrm{t}$ de beterraba & 0,3 & -250 \\
\hline Cervejaria & por 1.0001 de cerveja & 300 & -2000 \\
\hline Destilaria & por 1.0001 de cereais & 1500 & -2000 \\
\hline Amidonaria & por $1 \mathrm{t}$ milho ou trigo & 800 & -1000 \\
\hline Curtume & por $l t$ de peles & 1000 & -4000 \\
\hline Lanifício & por $l \mathrm{t}$ de $\mathbf{l a}$ & 2000 & -5000 \\
\hline Alvejamento de tecidos & por $\mathbf{l}$ de tecidos & 250 & -350 \\
\hline $\begin{array}{l}\text { Tinturaria com corantes } \\
\text { sulfurados }\end{array}$ & por l t tecidos & 2000 & -3500 \\
\hline Celulose ao sulfito & por $l \mathrm{t}$ celulose & 4000 & -6000 \\
\hline Pasta mecānica p/papel & por $1 \mathrm{t}$ madeira & 50 & -80 \\
\hline Fäbrica de papel & por 1 t papel & 100 & -300 \\
\hline Viscose (seda artificial) & por $1 \mathrm{t}$ produto & 300 & -500 \\
\hline Lavanderias & por 1 roupas & 370 & -1000 \\
\hline $\begin{array}{l}\text { Açucar de cana, com des } \\
\text { tilaria de álcool }\end{array}$ & por l t cana & 300 & -450 \\
\hline Fecularia de mandioca & por $l \mathrm{t}$ mandioca & 150 & -250 \\
\hline Amidonaria (de mandioca) & por 1 t mandioca & 200 & -300 \\
\hline
\end{tabular}

FONTE: IMHOFF, KARL. 1966 (26) 
Na FIgURA 5.9 enumeramos os diversos aspectos que de vem ser considerados no posicionamento de lançamentos de efluen tes de estações de esgoto domésticos e industriais.

Esta anälise serve como roteiro na escolha de äreas para localização de zonas industriais, em função dos impactos am bientais que possam resultar das mesmas, com relação aos recur sos hidricos. 


\section{CARACTERISTICAS DAS LGUAS RESIDUÁRIAS}

- DOMÉSTICAS: - POPULACĀO CONTRIBUINTE, ATUAL E FUTURA

- estimativa da carga poluidora

- INDUSTRLAIS: - TIPOS DE PROCESSAMENTOS

- CARActerísticas dos REsiduos

- avaliacão da carga poluidora

CARACTERISTICAS DOS CORPOS RECEPTORES

- SITUAGÃo NA BACIA HIDROGRÁFICA

- Classe. USOS PREPONDERANTES

- CONDICŌEs DE QUALIDAdE ATUAIS

- CAPACIDADE de auto-depuraç̄o

- Condicōes de QuALIDAde DEsejadas

- POSICĀo EM RELACÃo aOS OUTROS manancials da bacia

\section{OUTROS ASPECTOS A CONBIDERAR}

- posicão em relacão aOS lócals de captaç̄o de águA para abastecimento HUMANO E OUTROS FINS

- ASPECTOS ESTÉTICOS E DE· ODORES

- efeitos sobre usos residencials, Recreacionals e outros usos sensiveis

- caracteristicas ambientaIs dos locals para estacōes de tRatamento DE ESGOTO, EM FUNCĀO DA SOLUCĀO ADOTADA.

- aspectos econōmicos. alternatnas de custos.

- RELACIONAMENTO COM OUTROS PROBlemas ambientais.

EXEMPLOS: (I) POLUICÃo dO AR E DESTINO dE RESIDUOS sólidos. NOS CASOS DE IN DÚSTRIAS.

(2) DISPOSICTO dOS LODOS RESULTANTES DOS TRATAMENTOS 
5.4 - Uso do solo e controle da poluição do ar

Conforme comentamos no item 4.3.3, o importante a se considerar com relação à poluição do ar é a concentração de po luentes nas áreas receptoras a preservar. Esta concentração de poluentes depende dos seguintes fatores:

(1) Tipos e quantidades de poluentes emitidos

(2) Transporte e dispersão dos polentes, pela atmosfe ra

(3) Posicionamento das fontes poluidoras em relaçäo às àreas receptoras

Jä dissemos, tambëm, qua as fontes de poluição do ar podem ser fixas ou móveis, sendo as medidas de controle varia veis para cada caso.

o disciplinamento do uso do solo tem papel muito im portante no controle preventivo da poluição do ar, pois a distri buição adequada das fontes de poluição atmosfērica em uma área urbana pode contribuir bastante para evitar os efeitos indesejā veis sobre àreas receptoras sensíveis.

Assim, o uso do solo deve ser feito considerando as características das fontes poluidoras, bem como a capacidade do ambiente de dispersar os poluentes.

Para isto, é preciso que sejam bem detalhados os três fatores citados acima, visando alcançar concentraçōes aceitäveis de poluentes, nas äreas a preservar.

5.4.1 - Controle de fontes estacionärias

5.4.1.1 - Potencial de poluição

Conforme jā vimos, as principais fontes emissoras de poluentes atmosféricos são os veículos automotores, a queima de combustiveis em fontes estacionärias e os processos industriais. os processos industriais e de queima de combustível em fontes estacionärias, podem contribuir com grande quantidade e variedade de poluentes do ar. 
Para uma avaliação preliminar do potencial de polui çäo por fontes estacionárias, é importante conhecer-se os tipos de atividades das indústrias.

Dependendo dos processos desenvolvidos em cada indús tria, a produçāo de poluentes pode ser grande ou não, existindo fäbricas completamente não poluidoras do ar.

- QUADRO 5.11 reune diversas informaçōes sobre a emi são de polventes, para värios tipos de fontes estacionärias de poluiçäo do ar. Atravēs do mesmo, podemos ter uma idéia dos poly entes emitidos em diversos processos industriais e outras fontes fixas.

E importante para o planejador que ele disponha de uma classificação geral das indústrias, em função do potencial de poluição do ar, a qual lhe orientarä na fase de planejamento do uso do solo. As indústrias consideradas mais poluidoras mere cerão maiores cuidados quanto à localização em relação às äreas receptoras sensíveis, zonas residenciais, escolas, hospitais, ā reas de lazer, entre outras.

No QUADRO 5.12 apresentamos uma classificação de in düstrias por emissão de poluentes, preparada para a Agência de Proteção do Meio Ambiente dos Estados Unidos.

0 QUADRO 5.13, extraído do mesmo trabalho, pode ser utilizado como meio de estimar a emissão resultante de vārias ín düstrias em conjunto, baseando-se na classificação apresentada no Quadro anterior. Os valores sāo apresentados em grama de polu entes emitidos por empregado e por hora de funcionamento da in dústria. Multiplicando-se os valores do QUADRO 5.13 pelo nümero de empregadoshora/ano, pode-se estimar a emissão total anual de cada tipo de poluente, para as diversas indūstrias.

A Agēncia de Proteçāo do Meio Ambiente dos Estados U nidos elaborou, também, um trabalho de compilaçāo de "fatores de emissão" de poluentes atmosfëricos, para diversas fontes poluido ras. (58)

- "fator de emissäo" relaciona a quantidade de poluen tes emitidos a algum indicador tal como a capacidade de produção de uma indüstria, a quantidade de combustível queimado ou uma unidade de comprimento percorrida por um veículo. Säo exemplos de "fator de emissäo": Kg de material particulado por tonelada de lixo queimado, $\mathrm{Kg}$ de $\mathrm{SO}_{2}$ por tonelada de determinado material 
QUADRO 5.11

Emissāo de poluentes em fontes estacionärias de poluição do ar

QUEIMA DE COMBUSTTVEIS EM FONTES ESTACIONARI AS
- Cinza

- Gases: oxidos de enxofre Oxidos de nitrogênio Oxidos de carbono hidrocarbonetos e aldeídos

- Fumaça

INDOSTRIAS DE MINERAIS NAO METALICOS

Produtos e material ce râmico e refratärio, c $\bar{i}$ mento amianto, vidro, concreto, produtos de gesso e produtos abra sivos a) Unidades de cimento asfältico Cerca de $2,5 \mathrm{Kg}$ de material parti culado, para cada tonelada de $=$ produto

b) Fabricação de cimento

Cerca de $14 \mathrm{~kg}$ de poeira para ca da barril(cerca de $170 \mathrm{Kg}$ ) de ci mento, em processo ümido Cerca de $17 \mathrm{Kg}$ de poeira para ca da barril de cimento, em proces so seco

c) Preparação de concreto Cerca de $0,09 \mathrm{Kg}$ de poeira por me tro de concreto manipulado

d) Fabricação de vidro Cerca de $0,9 \mathrm{Kg}$ de material par
ticulado por tonelada de vidro $=$ process ado

a) Redução do minërio de alumínio Cerca de 35 a $39 \mathrm{Kg}$ de fluoretos, expressos em flúor, por tonelada de alumínio processado

INDOSTRIAS HETALORGICAS: FUNDIÇOES

b) Fundi gão de ferro

Emissao de material particulado em Kg por tonelada de metal car regado, em funçäo do tipo de for no:

Cubilot............ 7,8

Revërbero........... 0,9

Elëtrico de indução.. 0,9

c) Processamento secundärio de aço Emissão de material particulado, em $\mathrm{Kg}$ por tonelada de aço carre gado, em função do tipo de forno: Elétrico à arco......6, 6,8 Elétrico de induçäo.. 0,045 Siemens-Martin......4, 8 
d) Fundiçāo de bronze e latão Emissao de material particulado, em $\mathrm{Kg}$ por tonelada de material carregado, em funçāo do tipo de forno:

Cadinho ......... 1,75

Elétrico .......... 1,35

Revérbero .........11,85

Rotatörio ........99,40

INDUSTRIAS METALORGICAS:

Produção de peças forjadas, laminadas, trefiladas e extrudadas
- Fumos metálicos

- Poeiras (das fundições)

- nèvoa e vapores de solventes (apli cação do revestimento de proteção)
IDUSTRIAS MECANICAS

Fabricação de mäquinas, aparelhos e equipamentos diversos
- Poeiras e nēvoas (dos departamentos de acabamento)

- Fumaça e fumos (do tratamento tër mico de peças)
INDOSTRIAS DE MATERIAL

ELETRICO E DE COMUNICA€̧ĀO

Fäbricas de material, apa relhos, utensflios e mäquinas elētricas; fábricas de lâmpada; fábrica de ma terial de comunicação
- Poeiras e névoas (dos departamentos de acabamento)

- Fumaça e fumos (do tratamento tér mi co de peças)
INDOSTRIA DE MATERIAL DE TRANSPORTE

Construção de embarcações; fabricação de automóveis, caminhöes, ônibus, bicicle tas, tratores, avióes, etc.
- Ao lado das linhas de montagem, as quais não são por si só fontes sig nificativas de poluiça do ar, ope rações subsidiārias, como fundição tratamento tërmico, trabalho em ma deira, galvanização e pintura, pō dem produzir todos os tipos de po luentes, incluindo emissoes de vă pores orgânicos
INDUSTRIAS DE MADEIRA E MOBILIARIO

Desdobramento, compensação e produção de chapas de madeira prensada; fa bricação de peças e es= truturas de madeira apa rellhada; fabricação de = artigos de cortiça; fabricação de móveis e col choaria
- Poeiras

- Gotículas de tinta

- Solventes

- Fumaça da queima de resíduos 
INDOSTRIAS DE PAPEL E PAPELÃO

(Processo Kraft)
- Sulfeto de hidrogénio

- Mercaptanas

- Material particulado

\section{INDOSTRIAS TEXTEIS}

Beneficiamento de matērias tēxteis de origem vegetale animal; fiaçoes, tecelagens, malharias
- Material particulado (fibras e finos), dos residuos de produ ção

- Vapores e névoas (da tintura,descoramento e lavagem)

- Fumaça (dos equipamentos de com bustão)
INDUSTRIAS DE PRODUTOS DE BORRACHA

Fabricação de pneumāticos, câmaras de ar e outros ar tigos de borracha, a partír de borracha natural ou sin tét ica
- Poeiras locais

- Carvão pretoldas operaçōes de mi s tura)

- Vapores de solventes orgânicos

- odores (na fabricação de borracharegenerada

\section{INDOSTRIAS QUTMICAS E}

\section{FARMACEUTICAS}

Fabricą̧ão de ilimitada va riedade de produtos a) Fabricação de äcido nítrico Cerca de $26 \mathrm{~kg}$ de óxidos de nitro gênio por tonelada de ácido prō duzido (base 100\%)

b) Fabricação de àcido sulfürico Cerca de 9 a $32 \mathrm{Kg}$ de $\mathrm{SO}_{2}$ e de 0,14 a $3,4 \mathrm{~kg}$ de névoas acidas, por tonelada de ácido produzido

c) Fabricação de anidro Ftálico Cerca de $14,4 \mathrm{Kg}$ de substâncias orgânicas (hexano), por tonelada de anidrido produzido)

d) Fabricação de ácido fosfórico Cerca de 9 a $27 \mathrm{Kg}$ de compostos gasosos de flüor por tonelada de $\mathrm{P}_{2} \mathrm{O}_{5}$ produzido

- Odores os mais variados

INDOSTRIAS DE PRODUTOS A LIMENTARES E BEBIDAS

Beneficiamento, torrefação, preparação e fabricaçao em geral de produ tos alimentares e bebi= da
- Poeiras(das operações de depilação e moagem)

- Torrefação de café Do torrador a fogo direto $-3,5 \mathrm{~kg}$ de partículas por tonelada de ca fé processado

Do resfriador - $0,65 \mathrm{~kg}$ de particulas, por tonelada de café pro cessado 
QUADRO 5.11 (continuação)

PROCESSO

POLUENTES EMITIDOS

- Processamento de peixes:

Odores de sulfeto de hidrogênio e trimetilamina

INCINERAÇAO DO LIXO

Emissão de partículas, em $\mathrm{Kg}$ por to nelada de lixo queimado:

Incinerador municipal (com cámara

de sedimentação $-7,65$

Incinerador comercial - 4,50

Incinerador predial - 12,60

OBS: INFORMAÇZES COMPILADAS DE NELSON NEFUSSI E FERNANDO DE A. GUIMARÃES. (39) 


\section{QUADRO 5.12}

Classificação geral de indústrias por emissão de determinados poluentes

\begin{tabular}{|c|c|c|c|c|c|}
\hline \multirow[b]{2}{*}{$\begin{array}{c}\text { TIPO DE INDOSTRIA } \\
\therefore \\
\end{array}$} & \multicolumn{2}{|r|}{ TIPO } & \multicolumn{2}{|c|}{ POLUENTE } & \multirow[b]{2}{*}{${ }^{N O}{ }_{x}$} \\
\hline & $\mathrm{SO}_{2}$ & $\begin{array}{l}\text { MATERIAL } \\
\text { PARTI CU- } \\
\text { LADO }\end{array}$ & co & $\mathrm{HC}$ & \\
\hline Produtos alimentícios & B- & B & $A$ & A & $B-$ \\
\hline Tëxtil & $B+$ & $A$ & A & B & B \\
\hline Confecçōes (roupas) & A & A & $A$ & B & $B+$ \\
\hline Madeira & A & $A$ & $A$ & A & A \\
\hline Mōveis & $A$ & A & $A$ & $A$ & A \\
\hline Produçāo de papel & $\mathrm{C}$ & $B-$ & A & B & C \\
\hline Impressöes e publicaçöes & A & $A$ & A & C & A \\
\hline Química & B - & B & B & B & B- \\
\hline Petróleo & C & c & c & c & C \\
\hline Borracha e plästicos & $B+$ & $A$ & A & $B+$ & $B+$ \\
\hline Produtos de couro & B & $A$ & $A$ & B- & A \\
\hline Pedras, argila, vidro & B & B & A & A & B \\
\hline Metais primärios & B & B & $B-$ & A & B \\
\hline Mäquinas e instrumentos & $B+$ & $B+$ & A & $B+$ & $B+$ \\
\hline Instrumentos elétricos & $B+$ & $A$ & A & $A$ & A \\
\hline Equipam. de transporte & A & $A$ & $A$ & $B+$ & $A$ \\
\hline $\begin{array}{l}\text { Instrumentos de precisão } \\
\text { cientifica }\end{array}$ & $A$ & $A$ & $A$ & $A$ & B \\
\hline
\end{tabular}

FONTE: AGENCIA DE PROTEÇÃO DO MEIO AMBIENTE DOS ESTADOS UNIDOS DA AMERICA. (18)

OBS: CLASSE A: Indústria leve, com pouco ou nenhum problema de poluifão, para o poluente considerado

CLASSE B: Indústria pesada. Cuidados devem ser adotados na localização de indústrias deste tipo.

B+ : mais prōximo da CLASSE A

B-: mais pröximo da CLASSE C

CLASSE C: Indūstria crítica. Cada indústria deverá se in dividualmente estudada, por especialista em poluição do ar, visando definir sua localização. 
QUADRO 5.13

Taxas de emissão de determinados poluentes atmosfëricos,por classe de indústria (em grama de poluente por empregado-hora)

\begin{tabular}{lrrrrr}
\hline $\begin{array}{l}\text { CLASSE DA } \\
\text { INDOSTRIA }\end{array}$ & $\mathrm{SO}_{2}$ & $\begin{array}{c}\text { MATERIAL } \\
\text { PARTICULADO }\end{array}$ & CO & HC & NO $_{\mathbf{X}}$ \\
\hline A & 6 & 5 & 2 & 6 & 6 \\
B+ & 24 & 15 & 22 & 20 & 18 \\
B & 75 & 86 & 75 & 53 & 46 \\
B- & 176 & 220 & 220 & 198 & 132 \\
C & 530 & 660 & 1320 & 595 & 350 \\
\hline
\end{tabular}

FONTE: AGENCIA DE PROTEÇÃO DO MEIO AMBIENTE DOS ESTADOS UNIDOS DA AMERICA. (18)

OBS. As classes de indústrias estão definidas no QUADRO 5.12 
processado; Kg de monōxido de carbono por quilômetro percorrido por determinado veículo.

Estes fatores são de grande importância para a estima tiva da carga poluldora existente em determinada área ou previs ta como consequéncia de novos processos a se implantarem.

Podem ser usadas, também, listas que classificam as indüstrias em função do potencial de poluição do ar.

NOS QUADROS 5.14 a 5.17 , relacionamos as indústrias tendo em vista o potencial poluidor da atmosfera: GRANDE, MEDIO, PEQUENO E LEVE (NÃO POLUIUORA).

Conforme jä ressaltamos, as indicaçōes destes Quadros, bem como as dos Quadros 5.11 a 5.13 , são muito üteis na fa se de planejamento. No entanto, para cada classe de indústria e xiste uma grande variedade de processos, mais ou menos poluido res.

Assim, estas classificaçōes gerais devem ser usadas com cautela,apenas como indicações gerais, üteis na fase de pla nejamento.

Na fase de implantação, principalmente das indüstrias classificadas como grandes poluidoras, deve ser feito um estudo detalhado do processo, por especialistas, avaliando-se minuciosa mente todos os aspectos.

5.4 .1 .2 - Dispersão de poluentes

Um fator importante a considerar na localização de fontes de poluição atmosférica é a capacidade de dispersão dos mesmos, a qual, conforme jā vimos, é função de parámetros meteo rolögicos, dentre os quais têm mais influência: a velocidade e direção do vento; e a estabilidade atmosfērica (inversōes tērmi cas).

o planejador deve conhecer informaçōes sobre estes pa râmetros, de modo que a meteorologia da poluição do ar seja con siderada durante o processo de planejamento. 


\section{QUADRO $5: 14$}

Indústrias potencialmente grande poluidoras do ar

MINERAIS NAOO METALICOS

- Fabricação de cal

- Fabricação de cimento

METALORGICA

- Siderurgia e elaboração de produtos siderürgicos

- Metalurgia dos metais não ferrosos

- Forjaria e fundição de produtos siderúrgicos e meta iúrgicos

PAPEL E PAPELÃO

- Fabricação de celulose de pasta mecãnica

- Fabricação de papel e papelão

BORRACHA

- Beneficiamento de borracha

PRODUTOS ALIMENTARES

- Abate de animais e preparação de conservas de car ne e banha de porco

QUTMICA

- Produção de elementos químicos e fabricação de pro dutos químicos inorgânicos e orgânicos

- Fabricação de matērias plästicas bāsicas e de fios artificiais

- Fabricação de pólvoras e explosivos (inclusive fós foros de segurança e fogos de artifíciol

- Produção de óleos brutos de essências vegetais e de matérias graxas animais (exclusive refinação de pro dutos alimentares)

- Fabricação de tintas, esmaltes, lacas, vernizes, im permeabilizantes e solventes

- Fabricação de produtos derivados de destilação do petrōleo

- Fabricação de produtos derivados de destilação do carvão de pedra(inclusive gás) e da destilação da madeira

- Fabricação de produtos químicos diversos;fabricação de adubos e fertilizantes

FONTE: PLANO URBANTSTICO BÁSICO DO HUNICTPIO DE SĂO PAULO. ISS9 


\section{QUADRO 5.15}

Indüstrias potencialmente médio poluidoras do ar

MINERAIS NATO METALIICOS

- Fabricaçāo de material cerâmicolexclusive de barro cozido)

- Fabricação e eleboração do vidro

METALORGICA

- Elaboração de produtos siderúrgicos e metalúrgicos, sem altos fornos (laminação, relaminação)

PRODUTOS ALIMENTARES

- Preparação de conservas de pescado

- Preparação e fabricação de produtos alimentares di versos; preparação e refinação de óleos e gorduras̄ vegetais destinados à alimentaçäo; fabricaçao de ra çöes balanceadas de animais

FONTE: PLANO URBANTSTICO BÁSICO DO MUNICTPIO DE SÃO PAULO.1969 (43) 
QUADRO 5.16

Indüstrias potencialmente pequena poluidoras do ar

MINERAIS NÄO METALLICOS

- Britamento e aparelhamento de pedras para construção e execução de trabalhos em märmore e granito

- Fabricação de telhas, tijolos e vasilhames de barro co zido (exclusive material cerāmico)

- Fabricação de peças, ornatos e beneficiamento de mine rais näo metälicos

METALORGICA

- Fabricação de estruturas metālicas

- Estamparia, funilaria e latoaria

- Serralheria, caldeiraria e fabricação de recipientes de a ço

MECÃN ICA

- Fabricação de māquinas motrizes não elētricas e de equi pamentos para transmissão

- Fabricação de mäquinas, aparelhos e equipamentos não e létricos para instalaçöes hidräulicas, térmicas, de veñ ti lação e de refrigeração

- Fabricação de mäquinas - ferramentas, mäquinas operatri zes e aparelhos industriais, inclusive peças e acessóri os

- Fabricação de máquinas e aparelhos para agricultura e indústrias rurais, inclusive peças e acessórios

- Fabricação de máquinas, aparelhos e equipamentos diversos

- Reparação de māquinas e aparelhos

MATERIAL ELETRICO E MATERIAL DE COMUNICAÇOES

- Fabricação de material elétrico

- Fabricação de aparelhos elétricos

- Fabricação de aparelhos e utensilios elétricos parafins comerciais e industriais

- Reparação de máquinas e aparelhos elétricos industriais

MATERIAL DE TRANSPORTE

- Fabricação de peças e acessōrios para veículos de autopropulsao

- Fabricação de carroçarias para veículos a motor

- Fabricação de bicicletas, triciclos e motocicletas, in clusive fabricação de peças e acessórios

- Fabricação, montagem e reparação de tratores não agríco las e máquínas de terraplenagem, inclusive fabricaçāo de peças

- Fabricação de veículos a tração animal e de outros veículos 


\section{QUADRO 5.16 (continuação)}

\section{BORRACHA}

- Fabricação de artefatos diversos de borracha

\section{PRODUTOS FARMACEUTICOS E MEDICINAIS}

- Fabricação de produtos farmaceuticos e medicinais para uso humano

- Fabricação de produtos veterinārios

\section{PRODUTOS DE PERFUMARIA, SABÕES E VELAS}

- Fabricação de sabões e sabonetes

- Fabricação de velas

\section{QUTMICA}

- Produção de elementos químicos e fabricação de produtos químicos inorgānicos e orgânicos; produção de glicerina; produção de reagentes químicos, exceto cloretos; unidades relacionadas na fabricação de sal pelo método de evapora ção e moagem

- Fabricação de matērias plästicas bäsicas e de fios artifi ciais: produção de galalite e outros plásticos de proteí nas; fabricação de fibras sintéticas pelos processos de amónia e acetato.

- Fabricação de preparados para limpeza e polimento, desinfe tantes, inseticidas, germicidas e fungicidas

- Fabricação de produtos derivados da destillação 3 de petró leo, fabricação de gäs nafta de 1.000 a $5.000 \mathrm{~m}^{3} /$ hora

- Fabricação de prodútos derivados da dȩstilação de carvão de pedra: produção de gás até $10.000 \mathrm{~m}^{3} /$ hora

- Fabricação de produtos químicos diversos: produção de fer tilizantes líquidos; produção de misturas fertilizantes

- Fabricação de pölvoras e explosivos; fabricação de fósfo ros de segurança

\section{TEXTIL}

- Fiação com operações de acabamento

- Fiação e tecelagem com operações de acabamento

- Tecelagens com operação de acabamento

- Acabamento de fios e tecidos não processados em fiação e tecelagem

\section{PRODUTOS ALIMENTARES}

- Beneficiamento, torrefação e moagem de produtos alimentares

- Prefaração de conservas de frutas, legumes, especiarias e condimentos vegetais 


\section{QUADRO 5.16 (continuação)}

- Pasteurização de leite e fabricação de laticínio

- Fabricação de açucar

- Preparação e fabricação de produtos alimentares diversos; preparação de café e malte solúveis; preparação de sal de cozinha

FUMO

- Preparação do fumo

- Fabricação de cigarros e fumos desfiados

- Fabricação de charutos e cigarrilhas

\section{BEBIDAS}

- Destilação do àlcool

MADEIRA

- Desdobramento, compensação e produção de chapas de madei ra prensada

- Fabricação de peças e estruturas de madeira aparelhada

DIVERSAS

- Fabricação de instrumentos e utensilios para usos técni cos e profissionais e de aparelhos de medida e precisão que contenham mercúrio

FONTE: PLANO URBANTSTICO BASICO DO MUNICTPIO DE SĂO PAULO.1969 (43) 


\section{QUADRO 5.17}

Indústrias potencialmente leve poluidoras do ar ou não po luidoras do ar

VESTUARIO, CALÇADO E ARTEF̈ÄTOS DE TECIDOS

- Confeç̧ão de roupas è agasalhos.

- Fabricaçăo de chapëús

- Fabricaçăo de calçado (exclusive de borracha)

- Fabricação de acessórios de vestuário

- Confecção de artefatos diversos de tecidos (exclusive fá bricaçào nas fiações e tecelagem)

EDITORIAL E GRAFICA

- Edição e impressão de jornais

- Edição e impressão de outras publicações periódicas

- Edição e impressão de obras de texto

- Impressão de material comercial e escolar

- Execução de serviços grä́icos diversos

\section{BEB I DAS}

- Fabricação de vinhos

- Fabricação de aguardante

- Fabricação de outras bebidas espirituosas

- Fabricação de cervejas e semelhantes

- Fabricação de bebidas não alcoólicas

\section{PRODUTOS ALIMENTARES}

- Refinação de açucar

- Fabricação de produtos de padaria, confeitaria e pastela ria e de sorvetes

- Fabricação de massas alimentícias e biscoitos

- Fabricação de balas, caramelos, gomas de mascar, bombons, chocolates e doces de leite

- Preparação e fabricação de produtos alimentares; fabrica ção de vinagre; fabricação de fermentos e leveduras; fă bricação de gelo; fabricação e preparação de produtos = alimentares diversos

\section{TEXTIL}

- Fiação (sem operações de acabamento)

- Fiação e tecelagem (sem operações de acabamento)

- Tecelagem (sem operações de acabamento)

- Malharia e fabricaçáo de tecidos elásticos

- Fabricação de artigos passamanaria, filós, rendas e bordados

- Fabricação de feltros, tecidos de crinas, tecidos felpu dos, impermeáveis e de acabamento especial

- Fabricação de artefatos téxteis nas fiações e tecelagens (sem operações de acabamento) 


\title{
QUADRO 5.1? (continuação)
}

\author{
PRODUTOS DE MATERIAS PLÁSTICAS \\ - Fabricação de artigos de baquelite \\ - Fabricação de artigos de ebonite \\ - Fabricação de artigos de galalite \\ - Fabricação de artigos de outras matérias plásticas
}

\section{PRODUTOS DE PERFUMARIA, SABÕES E VELAS}

- Fabricação de perfumes

QUTMICA

- Produção de elementos químicos e fabricação de produtos químicos inorgānicos; produção de alcalóides; manufatú ra de diöxido de carbono líquido; produção de hidrogē nio e oxigènio comprimidos; produção de fertilizantes = carbonatos; extração de taninos

\section{COUROS E PELES E PRODUTOS SIHILARES}

- Fabricação de artigos de selaria e correaria

- Fabricação de malas, valises e de outros artigos para viagens, de couros, peles e de outros materiais

- Fabricação de artefatos diversos de couro e peles

PAPEL E PAPELÃO

- Fabricação de artefatos de papel não associados á fabri cação de papel

- Eabricação de artefatos de papelão, cartolina, pasta de madeira ou fibra prensada, não associada à fabricação de papelão

MOBILIARIO

- Fabricação de móveis de madeira, vime, junco e simila res para residēncias

- Fabricaçāo de móveis de metal para residéncias, escritó rios, escolas e para casas de espetäculos e auditörios

- Fabricação de artigos de colchoaria (exclusive de espu ma de borracha)

- Fabricação de artigos diversos de mobiliārio

MADEIRA

- Fabricação de artigos de tanoaria

- Fabricação de artigos de cortiça

- Fabricação de artigos diversos de madeira e produtos a fins

MATERIAL ELETRICO E MATERIAL DE COMUNICAÇĀO

- Fabricação de lâmpadas

- Fabricação de material de comunicaçōes 


\section{QUADRO 5.17 (continuaçāo)}

\section{DIVERSAS}

- Fabricação de instrumentos de müsica e gravação de discos musicais

- Fabricação de escovas, brochas, pincēis, vassouras, enxu gadores e espanadores

- Fabricação de instrumentos e utensflios para usos técni cos e profissionais e de aparelhos de medida e precisão = que näo contenham mercúrio

- Fabricação de aparelhos e material fotogrāfico e de ótica

- Lapidação de pedras preciosas e fabricação de artigos de ourivesaria e joalheria

- Fabricação de brinquedos e artigos para esportes e jogos recreativos

- Fabricação de material de escritörio e escolar e de arti gos para fins industriais e comerciais

FONTE: PLANO URBANTSTICO BASSICO DO MUNICTPIO DE SÃO PAULO. 1969 (43) 
As informaçōes colhidas em estaçōes meteorolögicas so bre a velocidade e direção dos ventos, permite a elaboração da "rosa dos ventos", a qual mostra as frequências possíveis de corrēncia de velocidade c direção do vento em determinada regi äo, durante 1 ano.

Na FIGURA 5.10, mostramos um exemplo de uma "rosa dos ventos". Estas informaçōes são muito importantes, pois indicam,pelo menos, dois fatores a considerar com relação ao transporte e dispersão de poluentes atmosféricos: direção predominante do vento e direção crítica, onde o vento tem menor velocidade.

Por exemplo, observando a FIGURA 5.10, podemos verifi car que o sentido mais favorável ao transporte e a dispersão de poluentes é o Sudeste-Noroeste, enquanto que a situação mais des favorável corresponde ao sentido Nordeste-Sudoeste.

Deste modo, conforme jā foi observado anteriormente, é importante que se considerem não somente a direção predominan te do vento, mas tambēm as mudanças que ocorrem durante o ano, criando condiçōes de baixa velocidade e, portanto, menor disper são. Lugares sujeltos a maiores ventilaçōes devem ser preferidos para a localização de fontes poluidoras, pois permitem maior dís persão.

As condiçōes de estabilidade atmosfērica tambēm devem ser analisadas. Os dados meteorológicos podem indicar as äreas mais sujeitas a inversōes térmicas, as quais devem ser evitadas.

Conforme mostramos no ítem 4.3.3.2, aspectos topográ ficos devem, tambèm, ser considerados. Algumas àreas, tais como os vales ou zonas pröximas a elevações naturais devem ser evita das para a localização de fontes poluidoras, devido ser dificul tada, nestes casos, a dispersão vertical ou horizontal dos polu entes.

Por outro lado, pode-se facilitar a circulação do ar, atravēs da distribuição adequada das edificaçōes, aproveitando-se condiçōes naturais existentes, conforme mostraremos adiante.

Värios são os mëtodos existentes para se estudar a dispersão de poluentes emitidos por determinada fonte ou conjun to de fontes.

De um modo geral, três modelos de dispersão podem ser identificados:

- modelo da caixa ("Lax model") 


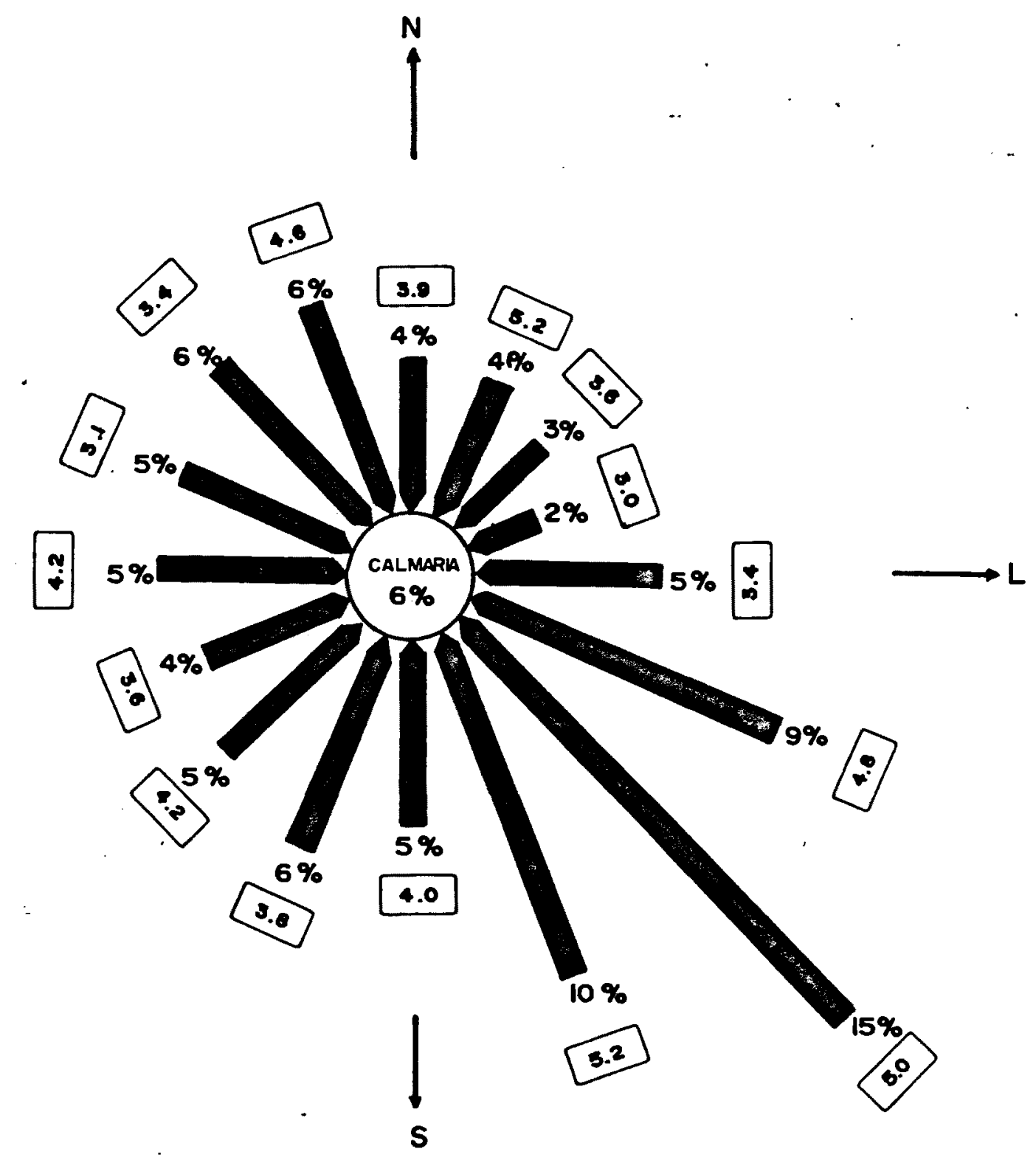

$0 \longleftarrow$

CONVENCĀO:

$5 \%$ - porcentagen do ano ouz o vento sopra A PARTIR dA DIRECTOO INDICAOA

4.6 - VElocidade MÉdia do VENTO, EM m/a 
- modelo da pluma gaussiana

- Modelos de simulação numērica

- "modelo da caixa" è o mais simples e é ütil em um estudo preliminar, podendo orientar ao planejador na escolha de äreas para instalação de fontes estacionärias, bem como na defí nição da intensidade de poluição das mesmas.

Este modelo é aplicado considerando uma concentraçāo uniformizada de poluentes em determinada ärea, avaliando-se os efeltos da emissão adicional de poluentes nesta ārea. Assim, não se consideram as variaçōes espaciais que normalmente ocorrem. mas admite-se que em toda àrea há uma taxa de emissão uniformiza da mëdia.

o modelo é utilizado através das seguintes etapas:

- Conhecimento da situação da ärea a preservar,em ter mos de concentração de poluentes existentes

- Definição dos teores máximos de poluentes anuais mê dios recomendados para a àrea (padröes)

- Comparando-se as concentrações de foluentes com os padrões recomendados, tem-se as quantidades de polu entes que podem ser, acrescidas (emitidas), sem maio res problemas para a ärea em planejamento, até atin gir os teores' mäximos.

Para a utilização deste método é necessária a elabora ção de um gráfico base, relacionando a concentração normalizada de poluentes (relação entre a concentração de poluentes sobre a ärea em estudo e a taxa de emissão na ärea) com o comprimento(má xima linha reta sobre a àrea em planejamento). (18)

o modelo gaussiano admite a dispersão de poluentes na atmosfera, a partir de uma fonte contínua, segundo uma pluma, pa ra a qual é definida uma expressão matemätica que permite calcu lar a concentração de um poluente em determinado local.

Assim, a concentração (C) de um poluente, em determi nado ponto de coordenadas $(X, Y, Z$ ) (FIGURA 5.11), a partir de uma fonte contínua de altura efetiva $H$, é dada pela expressão 


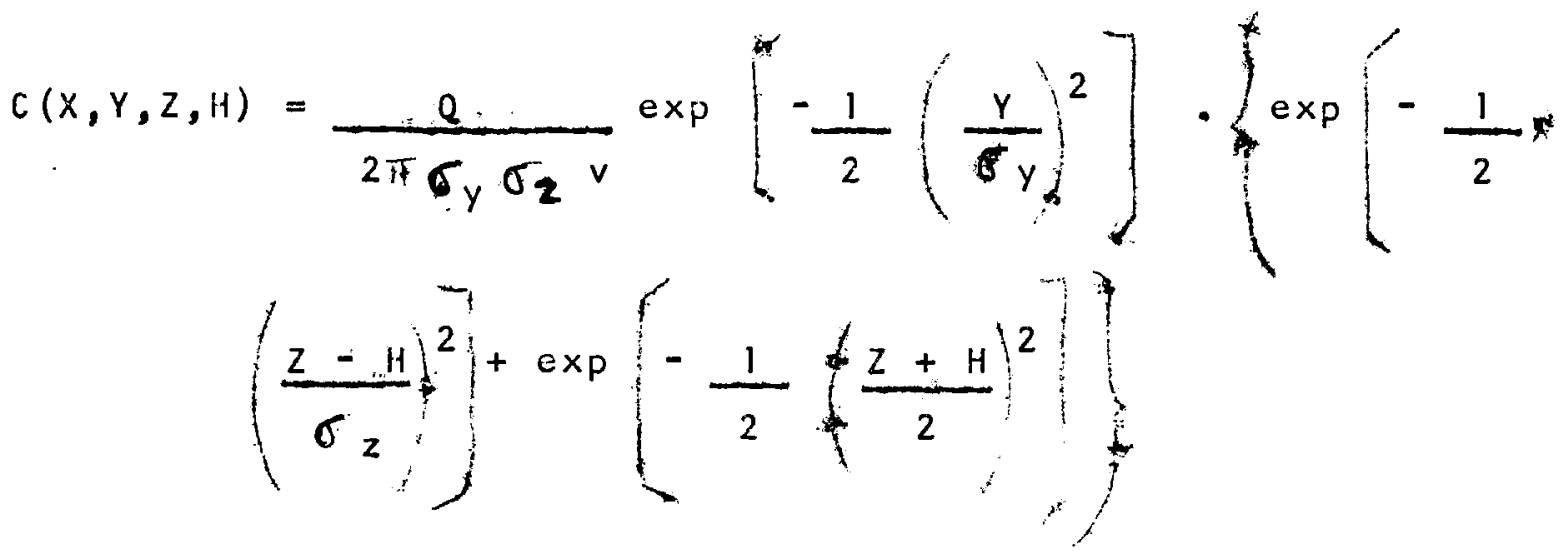

Onde:

$C=$ concentração do poluente $\left(\mathrm{g} / \mathrm{m}^{3}\right)$

$Q=$ taxa de emissão do poluente (g/seg)

$\sigma_{z}=$ coeficiente de dispersão vertical $(\mathrm{m})$
$\sigma_{y}$ coeficiente de dispersao horizontal $(\mathrm{m})$

$\sigma y=$ coeficiente de dispersaohor

$H=$ altura efetiva da chaminē (m)

$X, Y, Z$ em metros

Alterações na topografia podem modificar a dispersão de poluentes. Por exemplo, obstáculos criados na trajetória da pluma, tais como edificações, podem alterar sensivelmente o mo delo de dispersão dos poluentes emitidos.

os poluentes de simulação numērica são métodos mais sofisticados de avaliação da dispersão. Eles proporcionam infor maçöes detalhadas sobre o-comportamrnto dos poluentes no espaço, em escalas físicas relativamente pequenas. Estes modelos são mais aplicados na determinação de impactos sobre a qualidade do ar a partir de fontes individuais de grande efeito. Estes mode los encontram-se ainda em estägio de elaboração, prevendo-se am pla utilização futura.

os modelos de dispersão aqui comentados conduzem à elaboração de mapas de concentração de poluentes em uma área de terminada, a partir de uma fonte (ou conjunto de fontes) poluido ra. Estes mapas constam de curvas indicando as diversas concen trações de poluentes numa ärea, mostrando, portanto, as regiões com teores mais e menos elevados. São, assim, ūteis na orienta ção do disciplinamento do uso do solo. Na FIGURA 5.12 mostramos um exemplo da distribuição de concentrações de poluentes em uma ärea, a partir da emissão em determinada fonte.

outro aspecto a considerar com relação à dispersão de 


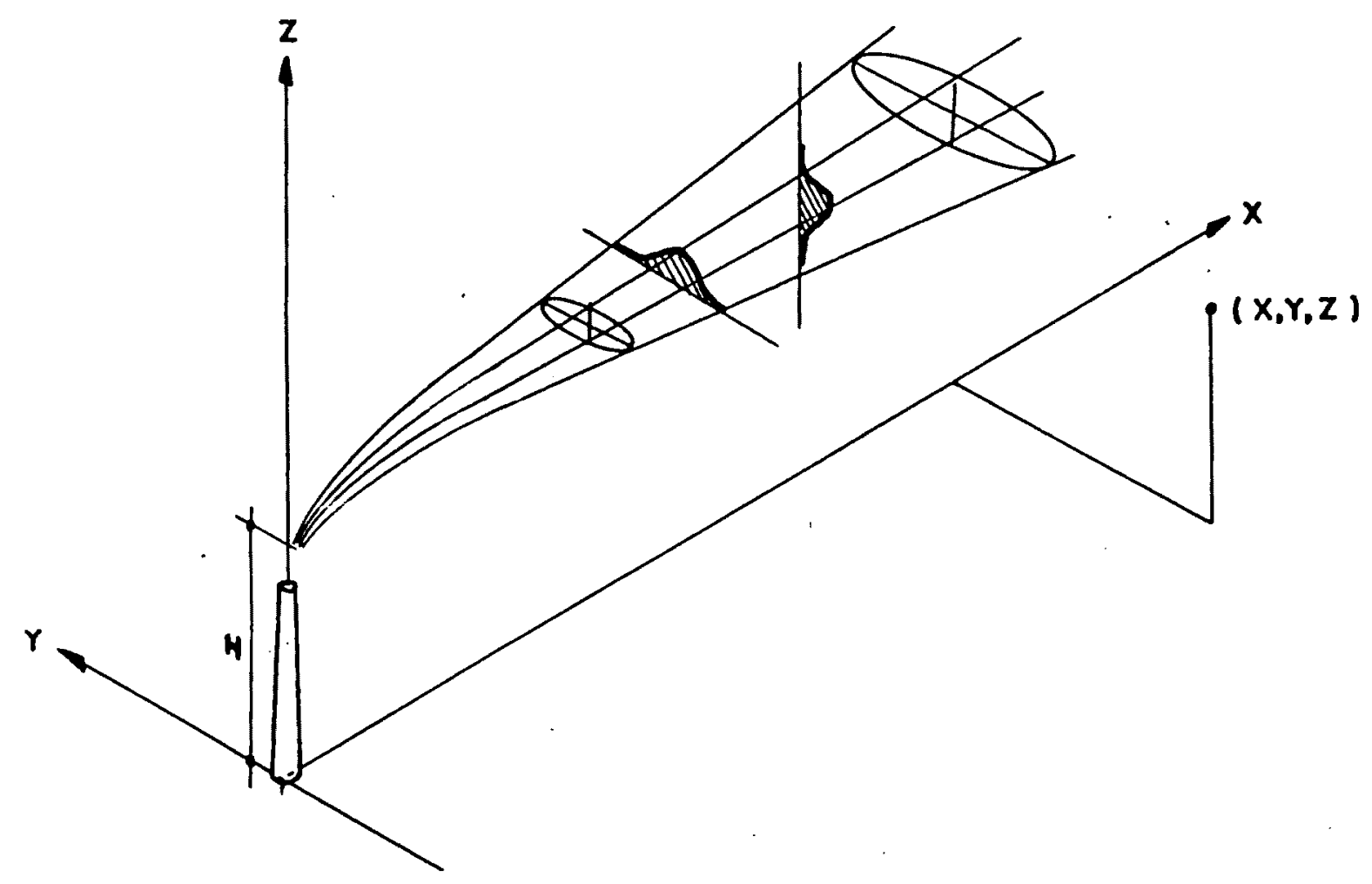

FI U URA S.II

ESOUEMA DE UMA DISTRIBUICT̃O GAUSSIANA

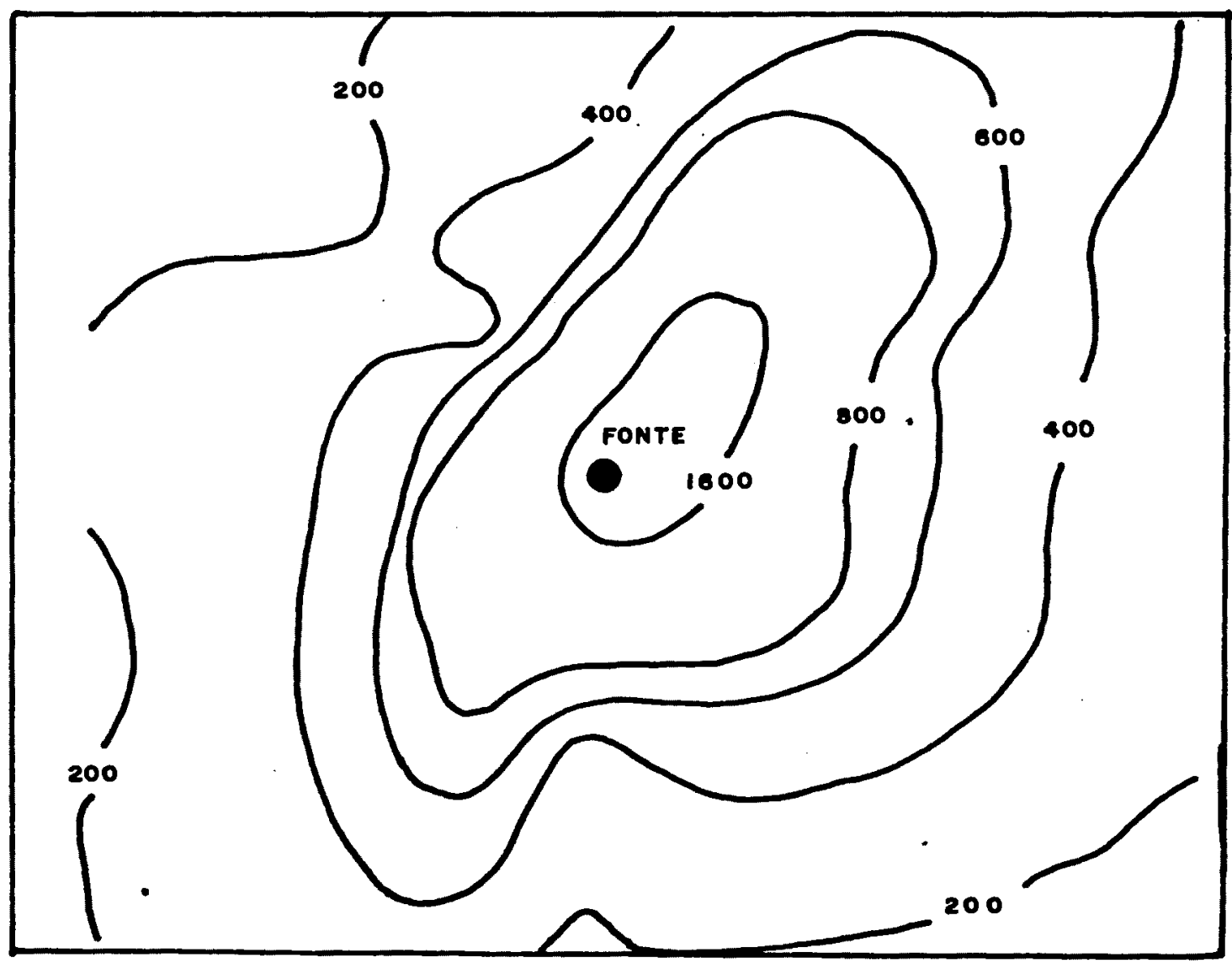

Fiouna $\mathbf{s . 1 2}$

EXEMPLO DE CURVAS DE CONCENTRACT̃O DE POLUENTES A PARTIR DE UMA FONTE (CONCENTRACÖES MÉDIAS ANUALS DE POLUENTES EM $\mu \mathrm{g} / \mathrm{m}^{3}$. A PARTRR DE UMA FONTE COM EMISSĀO DE 4000 oromos/sequnde 1 
poluentes, são os efeitos resultantes da forma em que as fontes são distribuídas. Em (18) são apresentados estudos comparativosde diversas distribuiçöes, como por exemplo: as fontes de polui fão concentradas em uma só área ou distribuídas em diversas āre as espalhadas; uma grande fonte ünica ou värias fontes pontuais espalhadas na ärea. Este trabalho enumerou as seguintes conclu söes:

- Quando as fontes dispersas em värias outras meno res, mas com a mesma emissāo total, a concentração mínima de poluentes ouservada aumenta notavelmente. Por outro lado, a concentração māxima de poluentes na ärea diminui sensivalmente.

- A dispersäo pode ser benéfica, para garantir que de terminados padröes de qualidade do ar näo sejam u! trapassados, jā que os valcres mäximos de concentra çöes são mais baixos.

- Usos receptores sensíveis (habitação, saúde, recrea ção, educaçāo, entre outros) devem situar-se muito distantes dos locais de fontes concentradas, onde as concentrações mínimas são menores. O espalhamen to das fontes, por outro lado, pode dificultar a disponibilidade de āreas para receptores sensíveis, pois os minimos de concentraçöes observadas, sendo mais elevados, podem ser superiores ao permitido pa ra estes usos.

5.4.1.3 - Critërios para a localização das fontes

Embora considerando a grande validade dos modelos de dispersão apresentados, devemos observar que os mesmos exigem in formaçōes e experiências de campo muito detalhadas, as quais pou cos municípios no Brasil têm condiçōes de desenvolver.

Assim, fica difícil a determinaçāo, de forma matemāti ca, dos efeitos de determinada fonte (ou fontes) emissora(s) de foluentes.sobre as äreas vizinhas.

Acreditamos que o conhecimento, pelo planejador, das 
condiçōes climāticas e topogräficas influentes no processo de po luição atmosfërica, ben como do potencial de poluição das indús trias (ou outras fontes estacionárias), pode ajudālo no discl plinamento do uso do solo visando a qualidade do ar. A ferramen ta principal que ele dispōe, após identificar as áreas mais favo ráveis, do ponto de vista climático ou topogrăfico, é o afasta mento entre as fontes poluidoras $e$ as àras receptoras.

Através de afastamentos adequados podem ser minimiza das as concentraçōes de poluentes em äreas sensíveis, ficando as mesmas dentro dos padröes de qualidade do ar.

E claro qua na fase de implantaçăo de indústrias mui to poluidoras, verificações mais dacalhadas devam ser desenvolvi das pelo örgão de controle da poluição do ar, as quais ajudarãoao planejador na definição do local exato adequado para as mes mas.

Os afastamentos minimos previamente estabelecidos pe ra as fontes poluidoras, em função do potencial poluidor das mes mas, fornecem uma diretriz geral para a definiçāo de zonas des tinadas ao uso industrial.

Este critērio é adotado na kússia, onde sāo dafinidas zonas de proteçāo sanitäria, com largura variāvel em funçāo do potencial poluidor das industrias. Assim, as fontes poluidoras devem situar-se a sotavento dos ventos predominantes e com os se guintes afastamentos: (20).

(1) Indústrias dafinidas como de classe 1 - zona de proteção sanitäria de $1.000 \mathrm{~m}$ de largura:

a) Indústrias quíricas

- Produção de compostos nitrogenados (amoníaco, äcido nitrico e adubos)

- Produção de compostos intermediärios da in dústria de corantes de anilina nas séries de benzeno e éter (derivados de anilina, nitro benzeno, fenol, etc.) cuja produçāo total se ja superior a 1.000 toneladas anuais.

- Produção de compostos intermediários nas sé ries do naftaleno e do antraceno (1-naftale nol, antraquinona, anidrido ftálico,etc.)em quantidades superiores a 2.000 toneladas anu ais. 
- Produção de brometo de ferro (111)

- Produção de soda cáustica e cloro por eletrólise

- Producão de adubos minerais concentrados

- Produção de dissolventes orgânicos e óleos

- Refinarias de petróleo

- Produção de ácidos, de um modo geral

- Produção de negro de fumo

- Produção de liquidos etílicos

- Produção de catalisadores

b) Outras indūstrias

- Fundição de ferro, quando o volume total dos al to-fornos é superior a $1.500 \mathrm{~m}^{3}$.

- Coquificação

- Fundição de materiais não ferrosos

- Instalação para a extraçāo de petrōleo e gás na natural

- Extração de minérios de chumbo, mercürio, arsêni co e manganès.

- Tratamento químico da madeira

- Produção de carvão vegetal

- Producão de colas e gelatina industrial a partir de restos animais (peles, ossos, cartilagens)

(2) Indústrias definidas como de classe 11 - zona de proteção sanitāria de $500 \mathrm{~m}$ de largura:

a) Indüstrias química

- Produção de urēia

- Instalaçõas de produção de gäs natural

- Produção e tratamento de alcatrōes naturais e de seus resíduos

- Sintesa do etanol pelo processo do ácido sul fürico ou por hidratação direta

- Produção de nitratos de amōnia, potässio, so dio e cälcio

- Produção de reagentes químicos orgãnicos

- Produção de èsteres

- Produção de resinas sintéticas

- Produção de nicotina 
- Produção de äcido acētico

b) outras indüstrias

- Instalações para a extração de fosforita, pi rita, antracito, carvāo vegetal, etc.

- Instalações para calcinar e moer ossos

- Instalaçōes para derreter gordura de animais marinhos

- Instalações para a lavagem de tripas, etc.

(3) Indūstrias jefinidas como de classe 111 - zona de proteção sanitāria de $300 \mathrm{~m}$ de largura:

a) Indüstrias químicas

- obtenção de betume e outros produtos a par tir dos resíduos de destilação do alcatrão da hulha, petróleo cru, etc.

- Produção de sais minerais, exceto os sais de arsēnico, fösforo, cromo, chumbo e mercürio (classe 1 )

- Produção de plásticos

- Produção de misturas fertilizantes

- Produção de metionina

- Produção de antibiōticos por métodos biolögi $\cos$

- Produção de laca, vernizes, etc.

b) outras indūstrias

- Exiração a cëu aberto de compostos metalóides

- Canteiros de rochas: dolomitas, magnesitas, amianto, alcatrão e asfalto

- Instalaçōes de impragnação de madeira para a sua conservação

- Instalações para tratar peles de gado vacumsem curtir

- Lavagem de lã animal

- Fābrica de antibiötico para raçāo de animais

(4) Indústrias definidas como de classe IV - zona de proteção sanitäria de loom de largura: 
a) Indūstrias químicas

- Fábrica de papel a partir da celulose já pre parada e trapos

- Produção de plästicos caseínícos e proteíni$\cos$

- Produção de glicerol

- Fäbrica de sabão

- Fäbrica de sal (evaporação e trituração)

- Produção de fertilizantes líquidos

- Produção de plastificantes polivinilicos, plásticos vinílicos, etc.

- Produção de alcalóides

- Produção de perfumes

b) Outras indüstrias

- Fäbrica de fios elētricos descobertos

- Fabricação de caldeiras

- Produção de eletrodos metálicos

- Produção de antimōnio por eletrólise

- Extração de sal-gema

- Produção de pedra artificial (argi la expandi da) e artigos de concreto

- Fabricação de vidro

- Fabricação de fios de seda

- Fiação de tecelagem de lã, algodão e linho, com seção de tinturaria e alvejamento

- Fabricação de feltro

- Torradores de café

(5) Indústrias definidas como de Classe V - zona de proteção sanitäria de $50 \mathrm{~m}$ de largura:

a) Indüstrias químicas

- Produção de reagentes inorgânicos

- Vulcanizaçäo de borracha sem o emprego do sulfeto de carbono

- Produção de $\mathrm{CO}_{2}$ e de neve carbônica

- Produção de përolas artificiais

- Produção de fertilizantes com o emprego de $\mathrm{CO}_{2}$ 
- Produçăo de tintas de imprensa

- Elaboraçăo de preparaçōes farmacéuticas

b) Outras indústrias

- Produçāo de acumuladores alcalinos

- Imprensa

- Instalaçōes para trabalhar o granito

- Producão de artigos da gesso

- Carpintaria, marcenaria

- Fiação e tecelagem de lä, algodão e linho, sem seção de tinturaria e alvejamento

- Fabricąão de roupas em geral

- Fabricação de calçado

- Fäbrica de doces, conservas, laticínios,etc.

- Padarias

- Cervejaria

UBALDO CARPIGIANI propōe a adoçäo de faixas sanitär as de Proteção, entre as fontes de poluição e outras äreas de edificaçōes em geral (habitaçōes, saüde, educação, sociais), e àreas de recreação. (13) A classificaçõo das fontes de polui ção adotada fol a do Plano Urbanístico Bäsico do Municipio de São Paulo, apresentada nos QUADROS 5.14 a 5.17 . São as seguintes as faixas propostas:

(I) Para indūstrias potencialmente grande poluidorasdo ar:

- Situadas a favor do vento predominante:Faixa Sa nitäria de, no mínimo, $1.500 \mathrm{~m}$

- Situadas contra o vento predominante: faixas sa nitäriá de, no minimo, $1.500 \mathrm{~m}$, acrescida de mais um afastamento, a critério da autoridadesanitäria.

(2) Para indústrias potencialmente médio poluidoras do ar:

- Situadas a favor do vento predominante:faixa Sa nitäria de, no mínimo, $500 \mathrm{~m}$.

- Situadas contra o vento predominante: Faixa sa nitäria de, no minimo, $500 \mathrm{~m}$, acrescida de mals um afastamento, a critērio da autoridade sanitā ria 
(3) Para indústrias potencialmente pequena poluido ras do ar:

- Situadas a favor do vento predominante: Faixa Sanitäria de, no mínimo, $300 \mathrm{~m}$

- Situadas contra o vento predominante: Faixa sa nitäria de, no mínimo, $300 \mathrm{~m}$, acrescida de mais um afastamento, a critērio da autoridade sani täria

(4) Para indústrias potencialmente leve poluidoras do ar:

- Situadas a favor do vento pradominante: faixa Sanitäria die, no mínimo, $100 \mathrm{~m}$

- Situadas contra o vento predominante: Faixa Sa nitāria de, no mínimo, 100m, acrescida de mais um afastamento, a critério da autoridade sani täria

(5) Para indüstrias não poluidoras

- Faixa Sanitäria de, no mínimo, $50 \mathrm{~m}$

Entendemos que estes afastamentos servem como orien tação muito ütil na implantação de zonas industriais de médio porte, em locais onde as informações são escassas. E claro que a localização dos grandes complexos industriais deve merecer es tudos mais aprofundados de especialistas em poluição do ar e planejamenta.

Existem indüstrias de altíssimo potencial poluidor, as quais não devem, jamais, situarem-se em āreas urbanas. Alguns exemplos podem ser citados:

- Indūstria de produção de celulose pelo processo "Kraft", na qual a emissão de odores pode atingir distâncias de cerca de 20 quilômetros, se não hou ver controle na fonte.

- Indústria de produção de cimento, onde hä uma emís são de poeiras em grande quantidade.

- Indūstrias siderúrgicas.

- Refinarias de petróleo. 
Resumindo o que dissemos ate aqui, podemos afirmar que o mais importante é que sejam considerados aspectos ambien tais na localização de fontes estacionärias de poluição do ar.

o. processo de planejamento para definir a localizaçäo de atividades poluidoras do ar, visando efeitos mínimos sobre a reas receptoras sensiveis, deve constituir-se de diversas eta pas, conforme indicado na FIGURA 5.13.

observamos que o processo compreende värias determina ções, relacionadas com as fontes emissoras de poluentes, com o meio dispersor e com as àreas receptoras. Estes estudos deveráo ser mais ou menos detalhadis, em função da maior ou menor comple $x i$ dade das atividades poluidoras.

o processo deve definir, então, um disciplinamento do uso do solo de forma a distribuir as diversas atividades no am biente, sem comprometer a qualidade do ar nas äreas receptoras consideradas mais sensiveis.

Na FIGURA 5.14 apresentamos um exemplo de uso do solo com este objetivo. E claro que não se pode definir um modelo fi xo de uso e ocupação, pois as variăveis intervenientes são mui tas, variando para cada município. No entanto, considerando-se critērios ambientais na localização de fontes estacionārias de poluiçäo,podem-se definir usos e ocupaçöes do solo compatíveis para as fontes poluidoras e as atividades consideradas mais sen síveis à poluição do ar.

5.4 .2 - Controle de fontes möveis

Conforme já comentamos, os veículos automotores parti cipam com grande parcela da carga poluidora do ar, principalmen te nos grandes aglcmerados urbanos, onde o nümero de carros $\vec{e}$ elevado e as condiçōes precārias de circulação dos mesmos contri buem para agravar o problema.

os veículos sãc responsäveis pela emissão, em maior proporção, de alguns poluentes determinados nas grandes cidades, tais como o morioxido de carbono, os óxidos de nitrogênio e os hi drocarbonetos. Estes poluentes são originärios, normalmente, do cano de escape, do respiro do carter, do carburador e do tanque de gasolina. Há ainda a emissão de material particulado, como re 


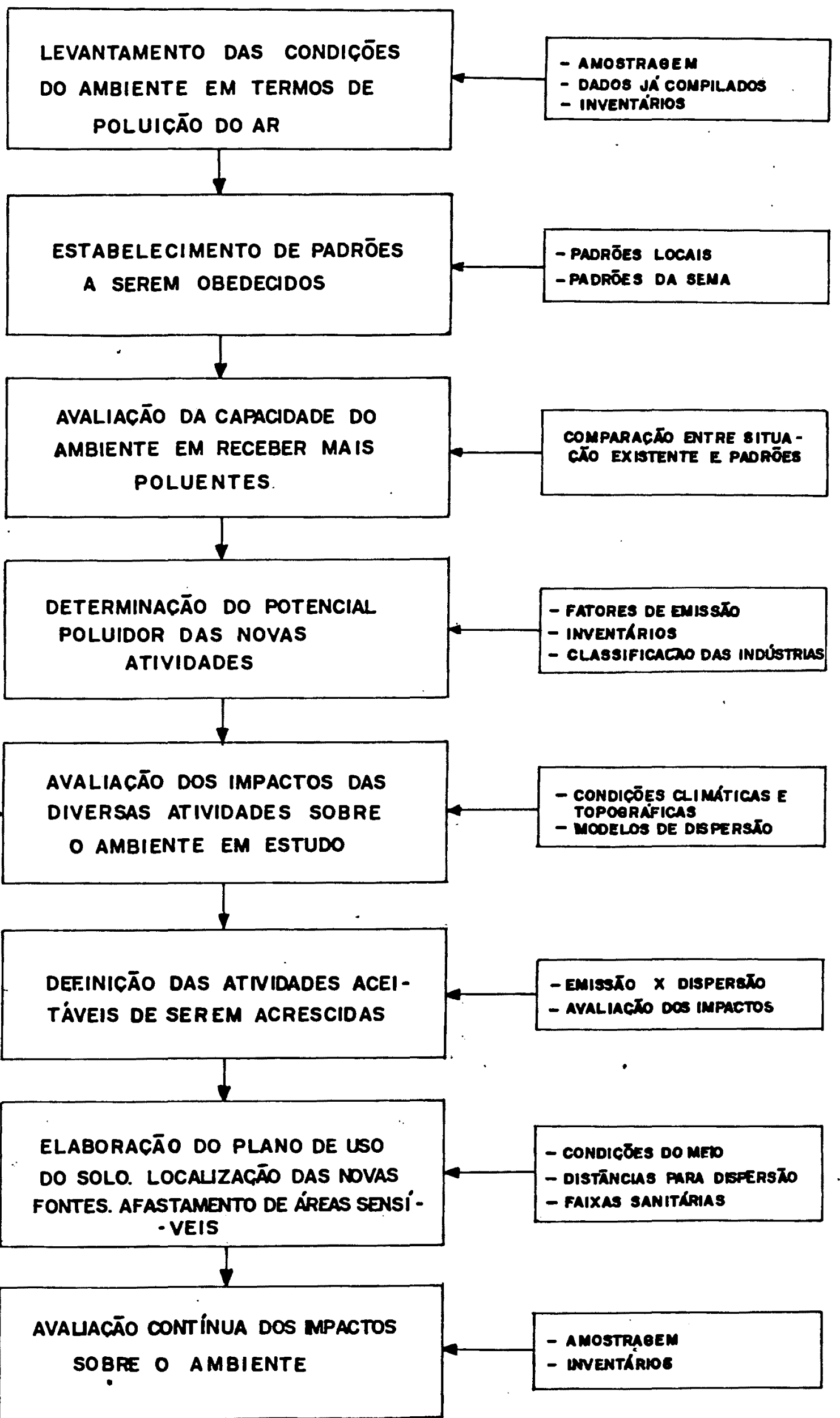




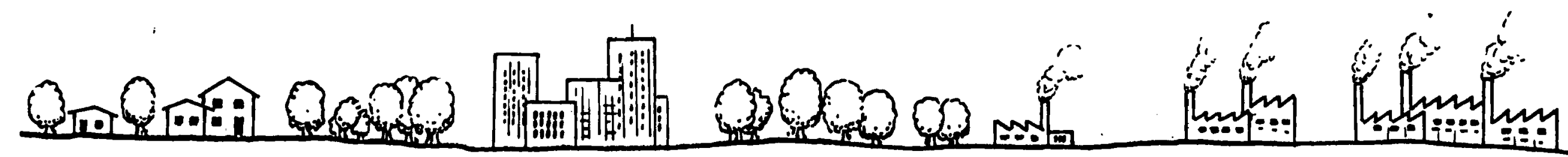

\begin{tabular}{|c|c|c|c|c|c|c|}
\hline $\begin{array}{l}\text { USO RESIDENCIAL, } \\
\text { ESCOLAS, HOSPITAIS. } \\
\text { ETC. }\end{array}$ & $\begin{array}{c}\text { ÁREA VERDE } \\
\text { ILAzER ATIVOI }\end{array}$ & $\begin{array}{l}\text { USO CONERCIAL, INS - } \\
\text { TITUICIOML, DE SER- } \\
\text { VICOS E INDUSTRLLL NTO } \\
\text { POLUIDOR }\end{array}$ & $\begin{array}{c}\text { AREA VER DE } \\
\text { ( UBO PAISAOIBTICO,LATER } \\
\text { PABSIVO) } \\
\text { ( }\end{array}$ & $\begin{array}{l}\text { USO INDUSTRLL } \\
\text { LEVE POLUIDOR }\end{array}$ & $\begin{array}{l}\text { USO INDUSTMLL } \\
\text { MEDIO POLUIDOR }\end{array}$ & $\begin{array}{l}\text { USO I MDUSTRIAL } \\
\text { OAANDE POLUIDOA }\end{array}$ \\
\hline
\end{tabular}


sultado do desgaste de pneus e de lonas de freio. Para a elaboração de um programa de controle da polui ção por fontes möveis è importante quc sa conheçam alguns aspec tos da emissão de poluentes por vaículos.

A emissão de monóxido de carbono, hidrocarbonetos e óxidos de nitrogênio em um veículo a.gasolina (tomando como base um veículo norte americano) é distribuida da seguinte farma: (34)

- Emissão de monóxido de carbono: $100 \%$ a partir do ca no de escapamento.

- Emissāo de hidrocarbonetos: 60\% do cano de escapa mento; $20 \%$ da evaporação no tanque de combustivel e carburador; $20 \%$ do respiro do carter.

- Emissão do öxidos de nitrogēnio: $100 \%$ a partir do cano de escapamento.

os veículos a diesel emitem fumaça e odor, alēm de produzirem hidrocarbonetos, oxidos de nitrogênio, compostos oxi genados e monöxido de carbono.

As taxas de emissão de poluentes variam de acordo com as características de funcionamento e idade do veículo, conforme mostrado no QUADRO 5.18. As observaçōes deste Quadro săo muito vālidas no estabelecimento de medidas de controle da poluição por fontes möveis.

Um programa de controle de poluição por fontes möveis deve compreender, basicamente, as seguintes açōes:

(1) Controle da emissão no veículo

(2) Mudanças no sistema de transporte

(3) Redução do nümero de viagens

(4) Melhoria no fluxo de veículos

(5) Distribuição adequade dos usos do solo

o disciplinamento do uso do solo pode influir nas qua tro ültimas atividades, jä que a primeira relaciona-se com o prö prio sistema de funcionamento dos veículos, para os quais deve rão ser definidos padröes mais rígidos de emissão de poluentes.

As mudangas no sistema de transporte deverāo ser de modo a incrementar os meios de circulação menos poluidores ou sem potencial de poluição. 
Emissão de poluentes em veículos a gasolina, em função das características de funcionamento

e idade dos mesmos

\begin{tabular}{|c|c|c|c|}
\hline CARACTERTSTICAS ESISSĀO & HOHOXIDO DE CARBONO & HI DROCARBONETOS & JXIDOS DE NITROGENIO \\
\hline VELCCIDADE MEDIA DO VETCULO & $\begin{array}{l}\text { Decresce com o aumento } \\
\text { da velocidade média }\end{array}$ & $\begin{array}{l}\text { Decresce com o au- } \\
\text { mento da velocida- } \\
\text { de média }\end{array}$ & $\begin{array}{l}\text { Cresce como aumento - } \\
\text { da velocidade médía }\end{array}$ \\
\hline ACELERAÇÃO & $\begin{array}{l}\text { Quanto mais variāvel a } \\
\text { valocidade, maior a ta } \\
\text { xa de emissáo. Paradas } \\
\text { e partidas aumentam a } \\
\text { emissão }\end{array}$ & $\begin{array}{l}\text { Cresce com a acele } \\
\text { raçäo ou desacele= } \\
\text { ração }\end{array}$ & $\begin{array}{l}\text { Nenhum efeito substan- } \\
\text { cial }\end{array}$ \\
\hline FUACIONANDO PARADO & Maximiza a emissão & Maximiza a emissão & $\begin{array}{l}\text { Nenhum efaito substan- } \\
\text { cial }\end{array}$ \\
\hline PARTIDA COM VETCULO FRIO & Aumenta a emissão & Aumenta a emissão & $\begin{array}{l}\text { Nenhum efeito substan- } \\
\text { cial }\end{array}$ \\
\hline IDADE DO VETCULO & Cresce com a idade & Cresce com a idade & $\begin{array}{l}\text { Menhum efeito substan- } \\
\text { cial }\end{array}$ \\
\hline TEMPERATURA DE OPERAÇÃO & $\begin{array}{l}\text { Nenhum efeito substan- } \\
\text { cial }\end{array}$ & $\begin{array}{l}\text { Nenhum efeito subs } \\
\text { tancial }\end{array}$ & $\begin{array}{l}\text { Cresce com a temperatu } \\
\text { ra de combustão }\end{array}$ \\
\hline
\end{tabular}

FOHTE: AGENCIA DE PROTEÇÃO DO NEIO AMBIENTE DOS ESTADOS UNIDOS DA AMERICA. (18) 
A distribuiçäo dos usos do solo de forma a reduzir as distâncias entre as zonas residenciais e as de trabalho, lazer, e outras, incrementará os percursos a pé, bem como a utilizaçào de bicicletas e de outros meios não poluidores. Para isto, deve rão ser criadas condições adequadas, tais como vias próprias pa ra circulaçãc de pedestres, pistas parabicicletas e motocicle tas, eáreas de estacionamento pröprias para estes equipamentos.

Programas de utilização de veículos particulares em cooperação devem ser incentivados, visando o maior aproveitamen to dos lugares vazios dos mesmos, com a consequente redução do nümeros de carros em circulação. Isto a conseguido, com sucesso, em empresas com grande nümero de emprogados, atraväs de incenti vos, tais como a concessão de vagas de estacionamento preferenci almente para tais veículos.

A melhoria e expansão do transporte coletivo é uma das medidas com melhor efeito sobre a qualidade do ar. 0 QUADRO 5.19 è bem esclarecedor, mostrando que hä uma redução sensível na emissão de poluentes, por passageiro, por percurso de viagem, quando é utilizado o transporte coletivo (ónibus). Os dados apre sentados referem-se a veículos americanos.

Värias medidas podem ser adotadas visando incrementar o uso do transporte coletivo:

- melnoria do sistema existente

- ampliação da frota de ônibus

- implantação de outros sistemas de transporte: trem, metró, bonde, etc.

- restrições à circulação de veículos parículares em determinadas äreas

- criação de vias específicas pora circulaçẽo de veí culos de uso coletivo

- facilidades de estacionamento para veículos coleti vus e dificuldades para os carros particulares.

Estas e outras medidas estão sendo implantadas

nas grandes cidades brasileiras com o objetivo de reduzir o consumo de combustiveis por veículos e, por certo, muito contribuirão pa ra melhorar a qualidade do ar nestes centros urbanos.

Um disciplinamento adequado do uso do solo favorece rā, tambēm, à diminuição do nūmero de viagens. Assim, uma mistü ra ordenada de usos residencial, comercial, de trabalho e lazer, 
QUADRO 5.19

Emissão de poluentes por automóveis e ônibus, por passageiro transportado, por milha. Estados Unidos da América. 1960 a 1973. (Emissōes em grama)

\begin{tabular}{|c|c|c|c|}
\hline POLUENTE TIPO DE VETCULO & AUTOMOVEL & $\begin{array}{l}\text { ONIBUS A } \\
\text { GASOLINA }\end{array}$ & $\begin{array}{l}\text { ONI BUS } \\
\text { DIESEL }\end{array}$ \\
\hline Monóxido de Carbono & 56,6 & 4,3 & 0,7 \\
\hline Hidrocarbonetos & 6,3 & 0,6 & 0,1 \\
\hline Oxidos de nitrogênio & 4,1 & 0,3 & 1,1 \\
\hline Diōxido de enxôfre & 0,12 & 0,03 & 0,08 \\
\hline Material particulado & 0,20 & 0,01 & 0,04 \\
\hline H: passageiro/veículo & 1,5 & 30 & 30 \\
\hline
\end{tabular}

FONTE: AGENCIA DE PROTEÇẼO DO MEIO FMBIENTE DOS E.U.A. (18)

OBS: $\quad 1 \mathrm{milha}=1,609 \mathrm{~km}$ 
facilitarä a realizaçōo de värias atividades com um nümero menor de viagens. E claro que a ordenação destes usos deve. levar em consideração outros aspectos, de forma que os mesmos sejam compa tiveis.

A melhoria do fluxo de veículos contribul para uma me nor emissão de poluentes. Ho QUADRo 5.18, mostramos que uma me nor quantidade de impurezas è lançada na atmosfera, quando os veículos circulam com maior velocidade, em deslocamentos unifor mes, sem aceleraçōes e desaceleraçōes sucessivas. Deste modo, de vem ser favorecidas as condiçōes de träfego, para que isto ocor ra. Tëcnicas de Engenharia de Träfego devem ser adotadas visando obter-se maior fluidez de träfego, evitando os congestionamentos responsäveis pelo agravamento da poluição atmosférica nas gran des cidades.

o disciplinamento do uso do solo nas proximidades de vias com intenso movimento de veículos pode contribuir para que áreas de uso sensiveis sejam menos afetadas, desde que dispos tas devidamente afastadas das vias.

Em (18) è apresentado um estudo no qual é feita a es timativa das concentrações de poluentes nas proximidades de au to-estradas, na direção do vento, observando-se variaçōes de teores com a distência da via, para värias velocidades do vento, condiçōes diversas de estabilidade atmosfērica e variações na emissão. Como conclusäo principal do referido estudo, temos: "Ge ralmente, as concentraçōes de todos os poluentes, ao nível do so 10, são maiores nas äreas imediatamente adjacentes às auto-estra das, calndo rapldamente, dentro de cerca de 80 metros, para apro ximadamente $30 \%$ do valor māximo, e então decrescendo gradativa mente com a distância, na direção do ventoll.

Com base neste estudo, pode ser proposta a utilização das āreas mais próximas às vias de grande movimento por ativida des menos sensiveis à poluição, ficando os usos mais afetados(re sidencial, hospitais, escolas, recreação, etc.) a distáncla maio res. Este afastamento è tambēm recomendado visando proteger os usos sensiveis contra o barulho produzido nas vias, conforme ve remos no ítem seguinte.

Areas livres, com vegetação, podem ser usadas como a tenuantes da poluição. A ação das ärvores sobre as concentraçōes de poluentes atmosfëricos è discutível, havendo, no entanto, um 
consenso de que elas produzem efeitos benëficos.

Por exemplo, em (62). encontramos a seguinte afirmat va: "A concentração mädía de polüentes decresce com a proporção da äreas lívres urbanas cum vegetação. Uma ărea verde com 30 me tros de largura proporciona uma quase completa intercepça de po eiras e reduçōes significativas nas concentraçōes de gases. Mes mo uma fila de ärvores pode reduzir significantemente a poluição do ar, se plantadas às mārgens das fontes poluidoras".

Ja em (11) è dito que: "Embora as ärvores, arbustos e outras características paisagísticas não afetem significantemen te a redução de poluentes, seja pelo efelto de barreira ou por ação bioquímica, elas interferem no velocidade do vento e na mís tura do ar. Arvores e outros elementos paisagisticos tendem a in duzir a turbuléncia no fluxo de ar, a qual proporciona a reduça da intensidade da poluição do ar, ao nível do solo, por causa do aumento da mistura. A existência de massas de vegetação próximas a edificações pode, tambēm, reduzir as pressões do vento contra as paredes externas, na direção dos ventos. Por outro lado, na direção conträrịa aos ventos, as ärvores tendem a atenuar o "efai to de vācuo". Então, em geral, as ärvores contrijuem para redu zir as pressães e väcuos contra paredes de edificaçöes e, destá forma, a infiltraçāo de poluentes para o interior. Por causa des tas considerações, alëm dos aspectos estëticos e ecolögicos, os projetistas devem aumentar $\dot{0}$ interesse em conservar ārvores adu tas e àreas de vegetação, procurando dispor os prédios em ötima posição em relação a estas características naturais".

De qualquer forma, podemos considerar benéficas as äreas verdes, recomendando-se a adoção de faixas verdes às mär geris de vias de grande movimento de veículos, visando atenuar a poluição atmosférica, bem como a poluição acūstica. Estas äreas, além do aspecto de afastamento, terão tambêm efeitos paisagísti cos, não sendo recomendado o seu uso como zonas de lazer.Um exem plo desta recomendação estä mostrado na FIGURA 5.15.

5.4.3 - Arranjo das eáificações e äreas livres

A distribuição adequada das edificações e āreas 
vres, pode contribuir para uma melhor circulação do ar e,portan to, malor dispersão e menor concentraçăo dos poluentes atmosfé rlcos em uma tidade.

Assim, o arranjo dos prēdios eàreas livres deve ser feito de forma a permitir a circulação natural do vento, como ín dicado na FIGURA 5.16 (b), evitando-se a criação de barreiras artificiais ou condiçōes para o confinamento do ar, conforme mos tra a FIGURA $5.16(a)$.

Uma adequada distribuição das āreas verdes nas cida des pode contribuir bastante para a melhor circulaçāo do ar. Con forme jă vimos, há um movimento natural do ar das äreas margi nais (normalmente, com vegetaçäo), para as zonas centrais das cidades. 0 conhecimento das direções predominantes do vento po de induzir a que se arranjem as áreas verdes radialmente em ré lação ao centro da cidade, favorecendo à criação de uma corren te de ar limpo e frio, dos arredores para as partes mais quen tes e poluídas da cidade, bem como contribuindo para uma melhor dispersão e afastamento dos poluentes produzidos nas àreas mais densamente ocupadas. (FIGUKA 5.17)

Estas e outras técnicas podem ser usadas pelos plane jadores, para garantir uma melior qualidade do ar nos centros urbanos. Constituem a adaptação dos processos naturais à urbani zą̧̃̃o. 


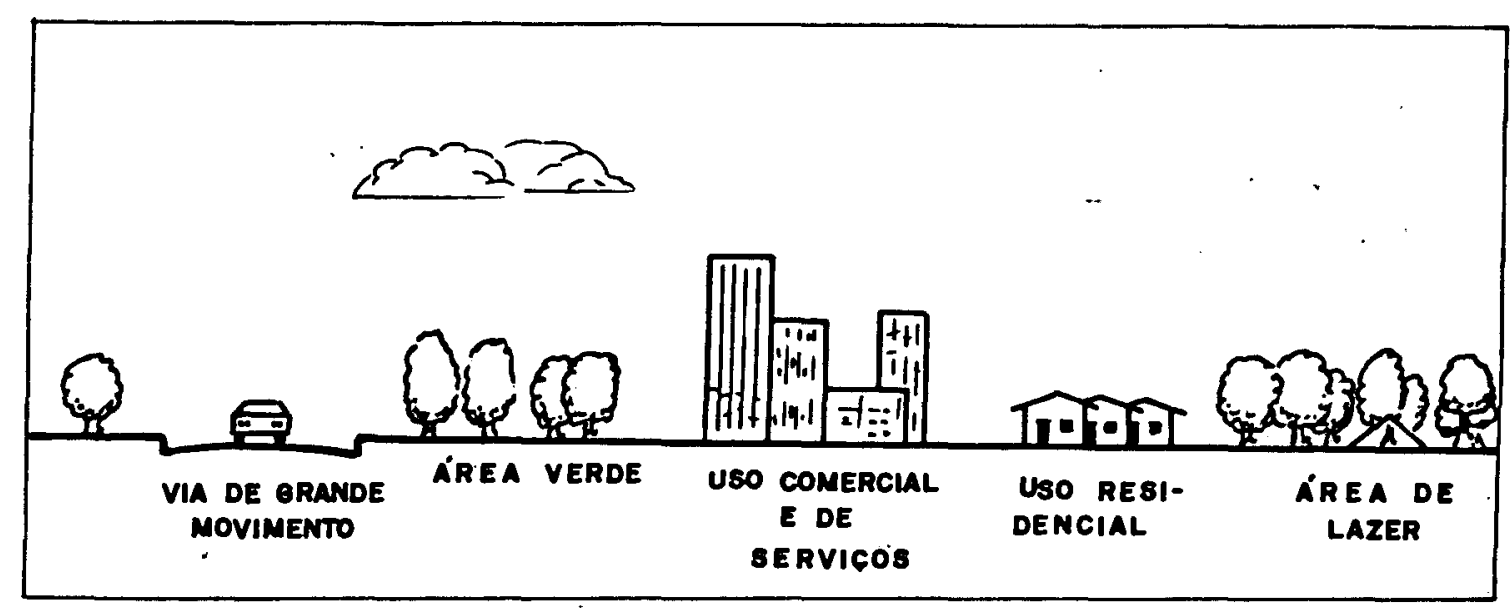

FIEURA 5.18

EXEMPLO DE USO DO SOLO VIZINHO A UMA VIA DE GRANDE MOVIMENTO DE VEICULOS

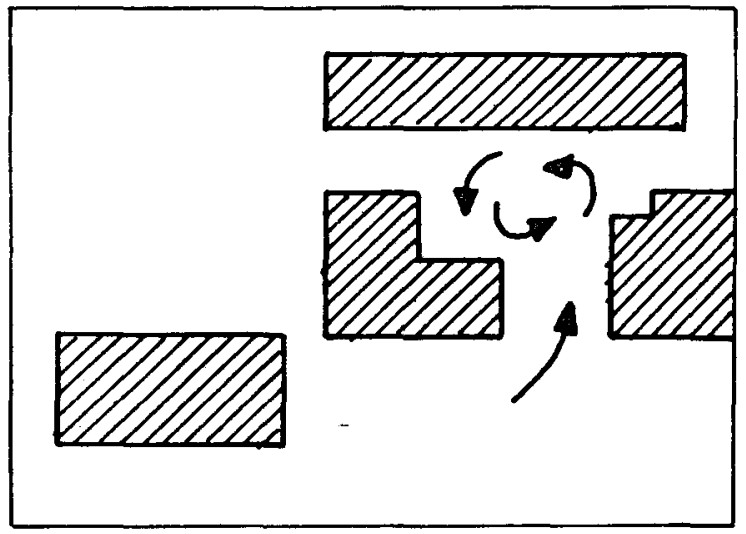

FI UURA $5.19(0)$

DISTRIBUICÃo INADEOUADA DE EDI-FICACÓE8

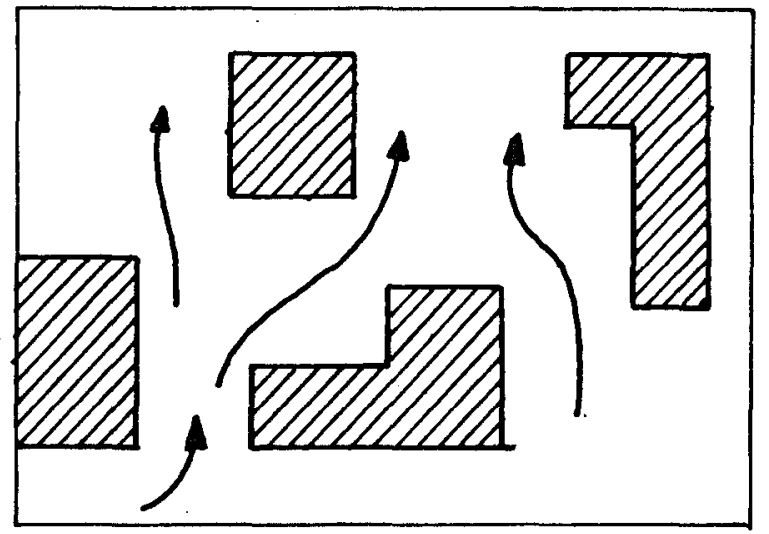

F I O URA 5.16 (b)

DISTRIEUICATO ADECUADA DE EDIFI- CACOEB

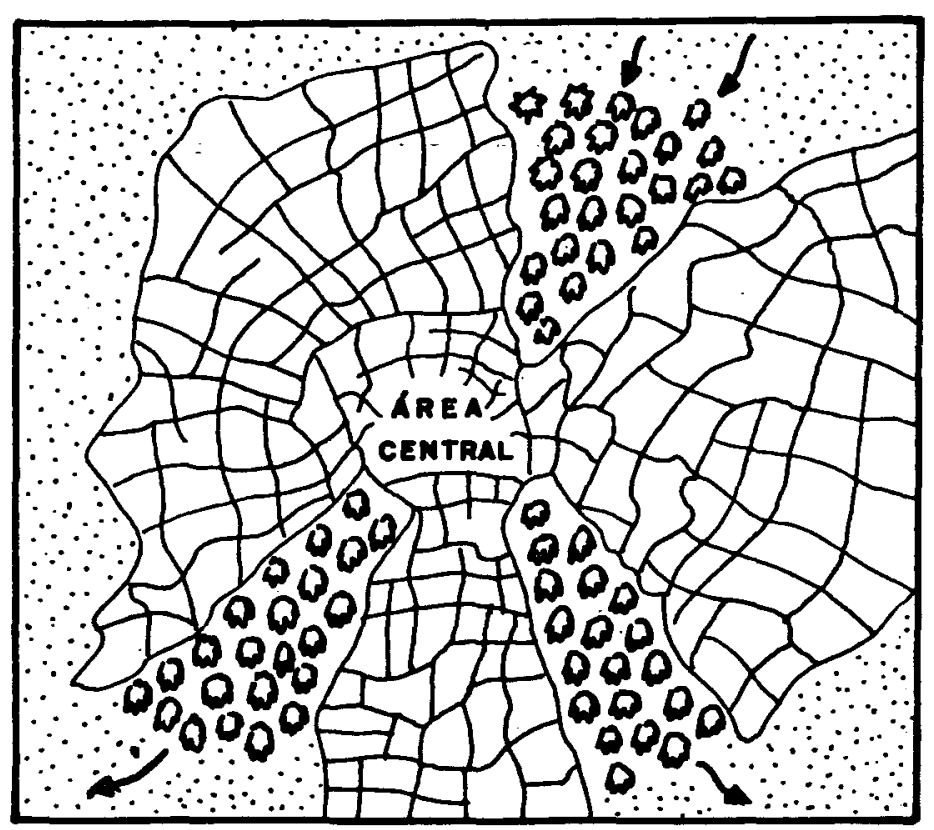

FIOURA $\mathbf{3 . I T}$

ARRANUO DAS ÁREAS VERDES FAVORECENDO A GIRGCULACĨO DO AR

\section{CONVENCTO \\ \#A area urbanizada

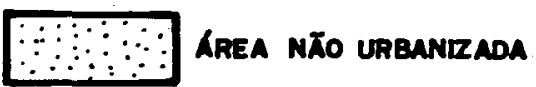 \\ Q000 area verde}


5.5 - Uso do solo e controle da poluição acūstica

A poluição acūstica envolve três componentes: a exís téncia de uma fonte geradora de ruídos; um meio propicio à trans missão; e um receptor.

Portanto; o controle desta modalidade de poluição de ve intervir, direta ou indiretamente, em um destes componentes, seja disciplinando a emissão de ruídos, seja criando dificulda des à transmissão dos mesmos ou afastarido os receptores sens veis das fontes.

Assim, o controle de pcluição acūstica envolve uma ou mais das seguintes providências:

- Controle da emissão: Iimitação dos níveis de emis são de ruídos; adaptação de processos industriais; isclamento de fontes de barulho; controle da emis são nos veículos; disciplinamento dos horärios de funcionamento de cquipamentos ruidosos, etc.

- Isolamentos acústicos: isolamento dos receptores, a travēs de dispositivos pröprios introduzidos nas dificaçöes de usos sensiveis ao barulho.

- Estabelecimento de padrōes, especificando os diver sos níveis de ruídos máximos para as diversas zonas da cidade, em função do uso.

- Adoção de medidas preventivas visando minimizar a propagação dos sons ef ou sua incidência sobre äre as de usos sensíveis ao barulho.

o disciplinamento do uso do solo estámais relaciona do com os dois ültimos tipos de providencias - estabelecimento de padrões e adoção de medidas preventivas - podendo contribuir sensivelmente para atenuar os efeitos da poluição acústica em äreas onde os níveis de ruídos não devem ser $a l$ tos.

Conforme veremos, o planejamento do uso de áreas adją centes a locais barulhentos, tais como algumas zonas industri ais, aeroportos ou vias com grande movimanto de veículos, pode ser feito de modo a dificultar a propagação dos ruidos ou a mini mizar a incidencia dos mesmos em àreas a preservar - zonas resi denciais, hospitais, igrejas, escolas, áreas de lazer, bibliote 
cas, etc.

5.5.1 - Niveis aceltä́le de ruídos

A fixaçăo de níveis de ruídos; definidos para as di versas zonas de uma cidade em funçẵo dö uso do solo; $\vec{e}$ uma medi da utilizada para controlar a poluíf̧ăo acüsticad

Assim, sāo recomendados diversos nifveís mäximos de ruídos para os värios usos, os quais dependem, tambèm, do perío do do día em que os mesmos são emitidos.

o QUADRO 5.20 é um exemplo do estabelcimento de ni veis mèdios de ruídos recomendados para diversas äreas, em fun ção do uso.

\section{QUADRO 5.20}

Nivais de ruídos recomendados para ambientes externos, em função do uso do solo - Suiça

\begin{tabular}{lcc}
\hline USO dO SOLO & $\begin{array}{c}\text { NTVEL MEDIO } \\
\text { NOITE }\end{array}$ & $\begin{array}{c}\text { RECMENDADO - dB } \\
\text { DIA }\end{array}$ \\
\hline Casa de repouso (saüde) & 35 & 45 \\
Residencial calmo & 45 & 55 \\
Misto & 45 & 60 \\
Comercial & 50 & 60 \\
Industrial & 55 & 65 \\
Vias de träfego & 60 & 70 \\
\hline
\end{tabular}

FOHTE: GATLEY, W.S. \& FRYE, E.E. 
os valores recomendados para cada zona variam de país para país, como também dentro de um mesmo país. Por exemplo, nu ma comparação feita entre as legislações de 23 cidades america nas, os niveis estabelecidos para o ruido em zonas resldenciais variaram de $60 \mathrm{~dB}(A)$ a $40 \mathrm{~dB}(A)$, com predominância de $55 \mathrm{~dB}(A)$ ou $50 \mathrm{~dB}(A)$.

Algumas legislaçōes, principalmente as que visam a se gurança de trabalhadores, fixam valores em funçāo do período de exposição das pessoas ao barulho. Como exemplo, mostramos no QUA DRO 5.21 os níveis recomendados para locais de trabalho no Esta do da Pennsylvania, nos estados Unidos da Amērica, bem como os limites de tolerância para ruído contínuo ou intermitente exigi dos no brasil, através da Portaria n? 3.214 , de 8 de junho de 1978, do Ministērio do Trabalho.

A Associação Brasileira de Normas Técnicas,atravēs da NB-95, estabelece vários níveis de ruídos aceitáveis em ambien tes internos, onde se realizem atividades de comércio,indüstria, arte, esporte e outras. (QUAORO 5.22). A Norma considera como ní vel de ruído aceitävel o valor mäximo do nível de som, dado em decibéis, que permite o mínimo conforto à maiorij dos ocupantes de um determinado ambiente.

Nāo é fäcil o estabelecimento de limites máximos de ruidos para os diversos ambientes. Devemos reconhecer que as pessoas reagem diferentemente ao barulho e que outros fatores, alēm da intensidade do som, influem no processo, tois como a fre quência de ocorrência ou tempo de exposição ao mesmo.

o controle de níveis de ruidos é facilitado quando se consideram amoientes isolados, internos às edificaçōes, tais co mo os locais de trabalho, bibliotecas, escolas, etc. Nestes ce sos, è mais fäcil a flscalização e o cumprimento de medidas visan do manter um determinado nival em um ambiente, garantindo, assim, as condlçōes recomendadas para os seus usuärios.

No entanto, alēm dos sons emitidos no Interior das e dificaçöes, existem os ruídos provenientes do meio exterior. Por exemplo, āreas situadas nas proximidades de aeroportos ou de vi as com grande movimento de veículos, estão sujeitas a ruídos em niveis superiores, muitas vezes, aos recomendados para alguns usos. 


\section{QUADRO 5.21}

Limites de ruídos em locais de trabalho, em funçāo do período de exposiçāo diäria. Estado da Pennsylvania (E.U.A.) e Brasil

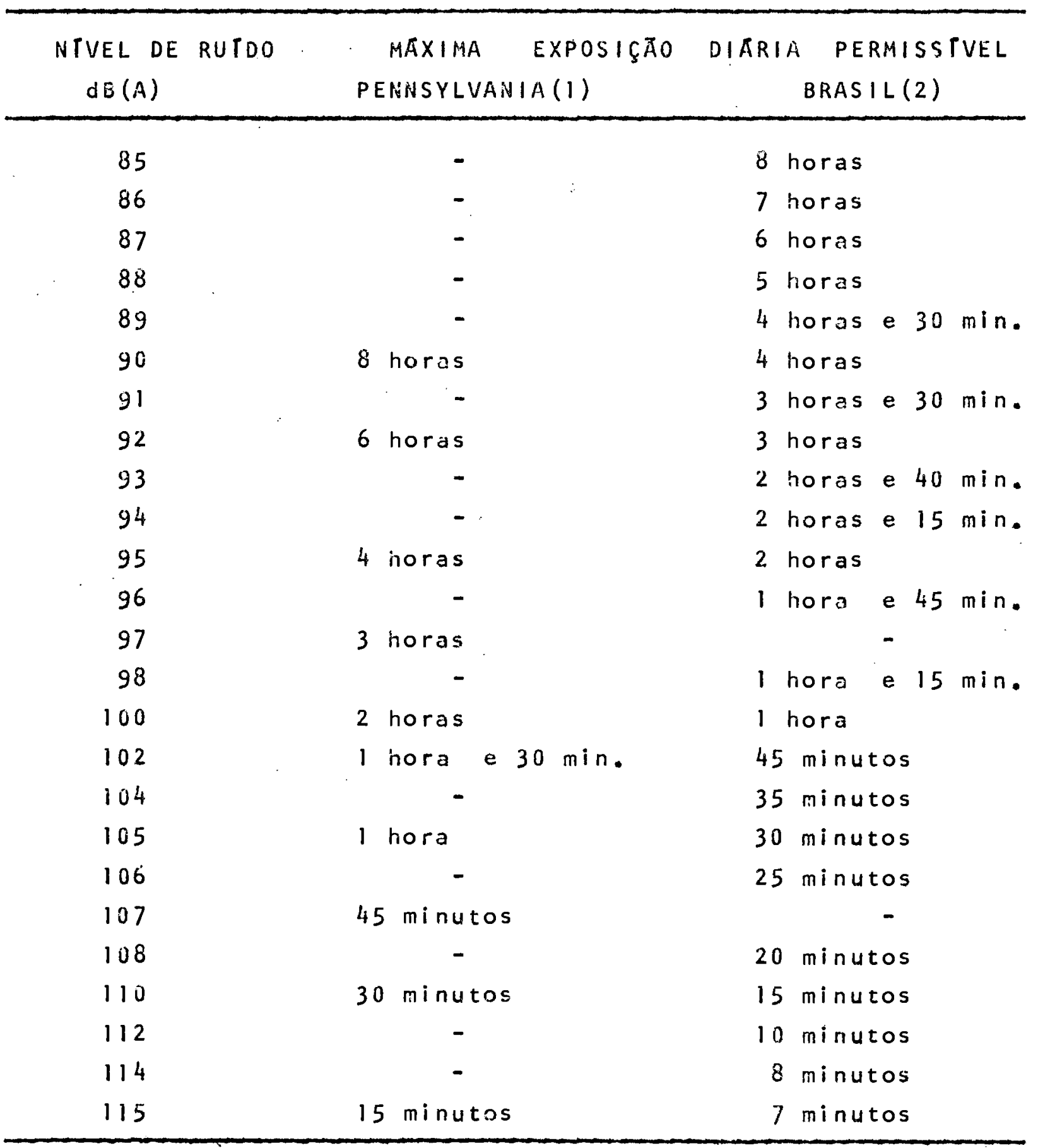

FONTES: (1) LEGISLAÇÃO DE CONTROLE AMBIENTAL DO ESTADO DA PENNSYLVANIA (E.U.A.)

(2) PORTARIA N: 3.214, DE 08 DE JUNHO DE 1978, DO MINISTERIO DO TRABALHO. 
Niveis de ruídos aceitäveis para ambientes internos, de acor do com a NB-95, da Associação Brasileira de Normas Técnicas.

$\begin{array}{lllllllll}A & M & B & I & E & N & T & E & \text { NTVEL DE } \\ \text { RCIDO } \\ \text { ACEITAVEL }\end{array}$

Bancos

$60 \mathrm{~dB}(B)$

Escritōrios

Datilografia, taquigrafia e escrituraçāo

Diretoria, cálculos, projetos, leituras de

plantas, salas de reunioes, contabilidade

Saguão principal e sala de espera

$60 \mathrm{~dB}(B)$

$57 d B(B)$

$60 \mathrm{~dB}(B)$

Hercados

$75 d B(B)$

Restaurantes e Confeitarias

Refeitórios

$60 d B(B)$

Copas a cozinhas

$65 \mathrm{~d} B(B)$

Lojas

$60 \mathrm{~dB}(\mathrm{~B})$

Auditórios e enfiteatros

Salas de espetäculos (não funcionando)

Sala de espera

$38 \mathrm{~d} B(A)$

$60 d B(B)$

$60 \mathrm{~dB}(B)$

$40 d B(A)$

Sala de tratamento

Hospitais e Consultörios Médicos

Enfermarias e quartos

Recepção, sala de espeŕa

Sala de oferaçöes

Lavanderia

Hotēis

Sala de estar

Sala de leitura

Restauranta

Copa, cozinha

Dormitório

Portaria e recepção

Igrejas e Templos (não em funcionamento)

Bioliotecas

$40 \mathrm{~dB}(A)$

$60 \triangle B(B)$

$35 \mathrm{~d} B(A)$

$55 \mathrm{~dB}(B)$

$47 \mathrm{~dB}(\mathrm{~A})$

$42 d B(A)$

$60 \mathrm{~dB}(B)$

$65 \mathrm{~dB}(B)$

$40 \mathrm{~dB}(A)$

$60 d B(B)$

$42 \mathrm{~d} B(A)$

$42 d B(A)$

cinemas

Sala de projeçāo (näo em funcionamento)

Sala de espera

$45 \mathrm{~dB}(\mathrm{~A})$

$60 \mathrm{~dB}(B)$

Teatros

Sala de espetäculos (nảo em funcionamento)

$38 \mathrm{~dB}(A)$

Sala de espera

$60 d B(B)$

$75 \mathrm{~dB}(\mathrm{~B})$

Ginásios e interiores para jogos e esportes 


\section{QUADRO 5 \&22 (continuação)}

\begin{tabular}{|c|c|}
\hline $\begin{array}{llllllll} & M & B & \text { I } & \text { E } & \text { H } & T & E\end{array}$ & $\begin{array}{l}\text { HTVEL DE } \\
\text { RUTOO } \\
\text { ACEITAVEL }\end{array}$ \\
\hline Museus & $42 d B(A)$ \\
\hline Escolas (não em funciónamento) & $42 d B(A)$ \\
\hline Tribunais (não em funcionamento) & $42 d B(A)$ \\
\hline Salas de müsica (não em funcioriamento) & $38 d B(A)$ \\
\hline "Stūdios" de gravaçāo (não em funcionamento) & $24 d B(A)$ \\
\hline "Stüdios" de rádio e TV (não em funcionamento) & $28 \mathrm{~dB}(A)$ \\
\hline Fäbricas & $75 \mathrm{~d} B(\mathrm{~B})$ \\
\hline Residências & $40 \mathrm{~dB}(\mathrm{~A})$ \\
\hline
\end{tabular}

OBS.: $d B(A)$ - nível de pressão sonora medido na Curva $A$ do sonômetro

dB(B) - nível de pressão sonora medido na curva $B$ do sonómetro 
Nestes casos, fica difícil o controle da emissäo, sen do, algumas vezes, impossível haver a redução desejada, na fon te. Em situações como esta, recomendamos a adoção de medidas pre ventivas, atrayés do disciplinamento do uso do solo no entorno de fontes de barulho.

5.5 .2 - Medidas preventivas de controle

Alēm da redução do tarulho na fonte, o controle da po luiçāo acūstica em äreas de usos sensíveis ê eficientemente con saguido através de medidas preventivas, as quais devem conside rar, principalmente, o efeito do afastamento entre estas zonas e as produtoras de ruídos em excesso. Algumas medidas preventivas serāo comentadas a seguir.

5.5.2.1 - Afastamento entre fonte e receptor

o afastamento entre fontes estacionärias de baruiho e as āreas receptoras é a medida mais eficiente paragarantir um nivel adequado de ruído em locais sensíveis à poluição acústica.

wo item 4.3.4, dissemos que a intensidade do som va ria com o afastamento, decrescendo inversamente com o quadrado da distancia a partir da fonte de ruído, significando que ocorre um decréscimo de 6 decibēis para cada vez que a distância em re lação à uma fonte emissora de som é dobrada.

Em (5) é feita a seguinte afirmativa: "A distāncia ne cessāria para que um nível de ruído alto, da órdem de 110 deci bëis seja atenuado para um valor satisfatório para o período di urno, que podemos considerar de 55 decibéis, è de aproximadamen te 1125 metros, considerando uma fonte pontual sem obstäculos. Para uma fonte de 90 decibēis, essa distāncia, nas mesmas condi çöes, cairia para 112 metros: Se considerarmos que sempre exis tem outras obstruçōes, como por exemplo, edificaçōes, na trajetö ria de propagação do som, essas distâncias seriam reduzidas sen sivelmente". 
A vegetação tem sido indicada como um meio que pode absorver o barulho, não havendo, no entanto, uma opinião formada definitiva sobre isto. Alguns, consideram o efeito de absorção das árvores, enquanto outros acham que as äreas verdes têm a fun fão apenas de afastamento e de criação de uma barreira visual en tre a fonte de barulho e os receptores.

A Organização Mundial da Saüde, no Relatōrio Técnico ne 297. de 1955, considerou os cinturōes verdes entre äreas indus triais e residenciais como um meio de proteça contra a indeseja vel propagaçäo de ruídos. (63)

De acordo com BRANCH, densas filas de ärvores ou ar bustos grandes plantados nas márgens de uma auto-estrada podem reduzir o barulho em cerca de 1 dB(A), para cada $1,20 \mathrm{~m}$ de espes sura, alēm de evitarem a visão direta, indesejävel, do tráfego.

WOOD considera que a vegetoção tem efeito, principal mente, em termos de afastamento. Para ele, o.gramado produz algu ma absorção de sons, enquanto superfícies povimentadas tendem a refletir o ruído. Uma densa barreira de vegetação necessitaria ter $50 \mathrm{~m}$ de largura para proporcionar uma redução de 10 dB(A). (62)

BERANEK, comentando pesquisas realizadas por diversos autores, diz que valores de atenuação de propagação do som em äreas verdes, a uma frequéncia de $1.000 \mathrm{~Hz}$, variaram de $23 \mathrm{~dB}$ por 100 metros, nos casos de densa vegetação, para 3 dB por 100 me tros, ou menos, quarido da existência de ärvores desfolhadas so bre o terreno. (7)

- Plano de Proteção Ambiental do Condado de Erie, Pennsylvania, nos Estados unidos, prevê uma redução significante dos ruídos emitidos em fäbricas e auto-estradas, na base de seis a oito decibejis para cada 30 metros de densa vegetação situada nas adjacências. (52)

Como vemos, são ainda bastante diversas as informa ções com relação ao efeito da vegetação sobre a propagação de ruídos. No entanto, devemos considerar como vảilo o efeito de afastamento proporcionado pelas äreas verdas, admitindo-se que as ärvores tenham alguma influência sobre o ruído. Deve-se levar em conta, tambēm, a barreira de percepção proporcionada pela ve getação. o efeito psicolögico è muito importante pois, não se ven 
do a fonte de ruidos, tem-se a sensação de que os mesmos sāo em. tidos em menor intensidade. Podemos dizer, com base nas citações feitas, que uma faixa com largura de 50 a $100 \mathrm{~m}$, com vegetaça densa, produzirä efeitos favoráveis na atenuação de ruídos prō prios do meio urbano.

Ainda baseando-se nas consideraçōes feitas até aqui, pode-se tomar cono medida principal de preservação de āreas sen síveis ao barulho, o afastamento das mesmas em relação às fontes emissoras de ruídos em excesso.

Assim, os diversos usos do solo devem ser devidamente distribuídos nas cidades, de forma a manter-se uma distancia ade quada entre as fontes de baruiho e as āreas receptoras mais sen síveis ao ruído. Este afastamento variará em função dos níveis de som emitidos e dos valores recomendados para as zonas recepto ras.

Entre o emissor e o receptor podem ser distribuídos outros usos menos sensiveis, de modo a interceptar a propagação do ruído. Por exemplo, entre indústrias com alto potencial de po luição acüstica e uma zona residencial, podem ser colocadas ou tras indústrias näo barulhentas, uma zona de uso comercial e de serviços, e uma àrea verde. Desta forma, poderão ser mantidos os níveis de ruidos recomendados para a zona residencial. Alèm da ärea verde, os prëdios, dispostos adequadamente, constitulräo im portantes barreiras à propagação do som.

Assim, no zoneamento das cidades, os níveis de ruídos aceitāveis devem ser um parâmetro a ser considerado na definição dos diversos usos do solo. A cidade deve ser, então, zoneada com värios níveis recomendados para as diversas äreas, em função das atividades a serem desenvolvidas nas mesmas.

5.5.2.2 - Controle de ruídos do träfego

o träfego de veículos constitul uma das maiores fon tes de barulho em uma ärea urbana. A intensidade dos sons resul tantes do träfego depende de värios fatores, tais como: tipo. quantidade e velocidade dos veículos; qualidade da pavimentação; fluxo do träfego, com aceleraçōes e desaceleraçöes; característi 
cas dos prieus dos carros.

os veículos pesadosi caminhões e ónibus, são os mais baruitientos, seguidos de motocicletas, carros esporte e outros veículos de passageitos:

o nível de ruidos produzidos em vias com träfego pesa do atinge, normalmente, de 70 a $90 \mathrm{~dB}(\dot{A})$.

Uma pesquisa realizada em Nova York, em 1970, medindo os niveis de som no exterior de janelas situadas no décimo sexto e décimo sētimo andares de três hotēis, revelou níveis de ruídos superiores a 100 decibēis, nas frequeñcias de 4.800 a $10.000 \mathrm{~Hz}$. (47)

E necessärio, portanto, que este especto de emissão de ruídos seja considerado no projeto de vias de grande movimen to de veículos. Assim, o planejador deve levar em conta a polui ção acüstica em àreas adjacentes a estas vias, procurando minimi zar os seus efeitos sobre āreas residenciais e outras, através do adequado disciplinamento do uso do solo.

värias medidas podem ser adotadas visando atenuar os efeitos do excesso de ruídos produzidos pelo träfego de veícu los, entre as quais destacamos:

(1) Melhoria dos equipamentos dos veículos, visando re duzir a emissão de ruídos.

(2) Restriçōes ao träfego de veículos pesados em de terminadas äreas da cidade, através de proibicão total ou definição de horàrios permitidos à circu lação dos mesmos.

(3) Incentivo ao transporte coletivo, visando reduzir o nümero de veículos por passageiro.

(4) Melhoria do fluxo de veículos, com o objetivo de evitar as acelerações e desacelaraçōes, provocado ras de barulho.

(5) Execução de barreiras à propagação do som, em ví as com träfego intenso. Estas barreiras podem ser executadas atravēs de elevaçöes do terreno (FIGU RA 5.18) ou construídas em alvenaria, concreto ou madeira. Sob o aspecto visual, a primeira soluçāo é a mais indicada, pois um tratamento paisagísti 
co pode ser adotadó disfarçardo a barreira. rëm, hem sempre se dispõe de espaço para este ti po de isolamento, nas vias já existentes, tendose mesmo que adotar os paredóes.

(5) Disciplinamento do uso do solo às märgens de vias de grande circulação de veículos, considerando os aspectos de propagação do som. Assim, ao longo destas vias devem ser dispostas äreas de vegeta çăo densa ou zonas de uso industrial e comercial. A disposição de prēdios, de modo a constituirem barreiras à transmissão do ruído, é uma medida fetiva. Hesmo em vias locais de grande movimento, è recomendāvel destinar-se os prédios das quadras adjacentes às mesmas para usos industrial lave, co mercial, de serviços, ou outros não sensiveis ao barulho, ficando as quadras seguintes para uso re sidencial e de lazer. O esquema apresentado na FI GURA 5.15, visando atenuar a poluição do ar, resul tante de veículos, pode ser utilizado, também, co mo medida preventiva da poluição acūstica.

(7) Utilização de tēcnicas de isolamento na constrü ção dos prédios, atravēs da adoção de materlais a dequados a não penetração dos sons. A orientação adequada da edificação em relação à fonte de ruI dos pode ser muito välida. Afastando-se os compar timentos mais sensíveis ao barulho, vertical ou horizontalmente, pode-se conseguir nívels adequa dos de ruídos nestes locais.

(8) Adoçāo de técnicas adequadas visando reduzir a propagação do som para āreas adjacentes a vias de tráfego intenso. o projeto adequado destas vias, utilizando cortes ou aterros espessos, nos tre chos onde as mesmas atravessam áreas sensivels à poluição acüstica, contribui bastante para atenu ar os efeitos indesejáveis do execesso de ruido." Na FIGURA 5,19, transcrita de (47), mostramos di versos tipos de projetos de vias de träfego pesa do, indicando as atenuações nos ruídos emitidos, para os diversus casos. 


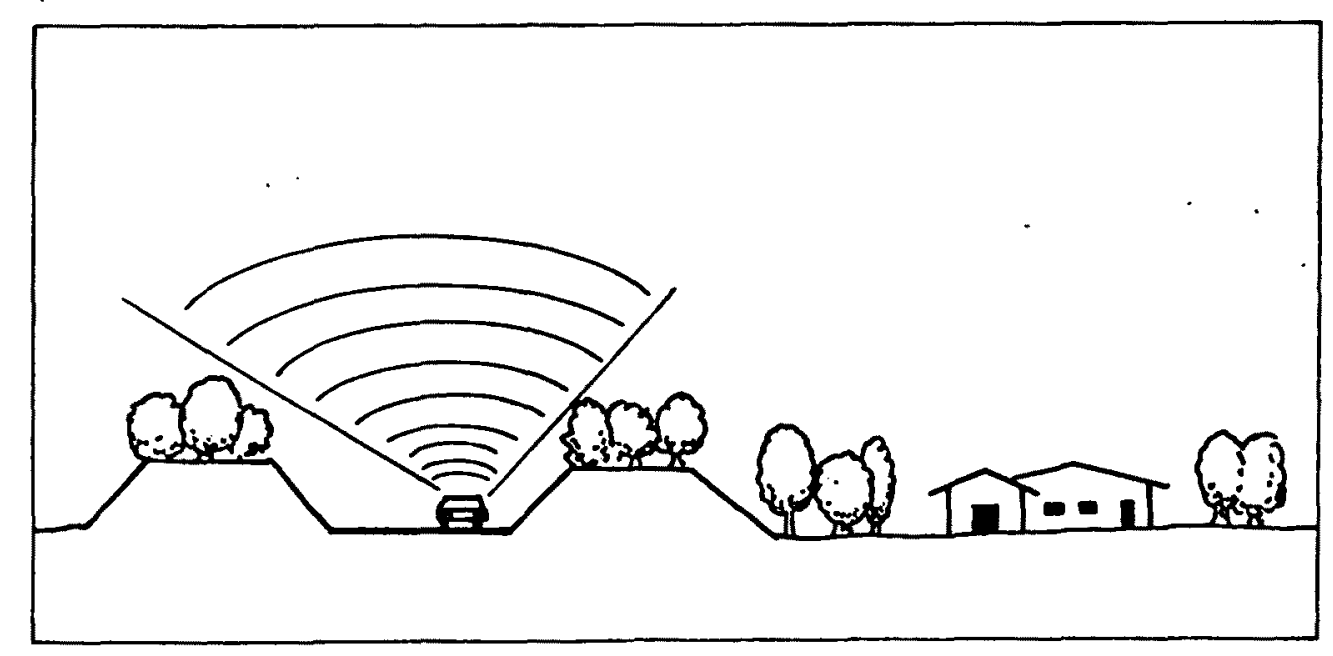

FI GURA $\mathbf{5 . 1 8}$

EXEMPLO DE BARREIRA CONTRA A PROPAGACÃO DO SOM RESULTANTE DE TRÁFE6O INTIN80

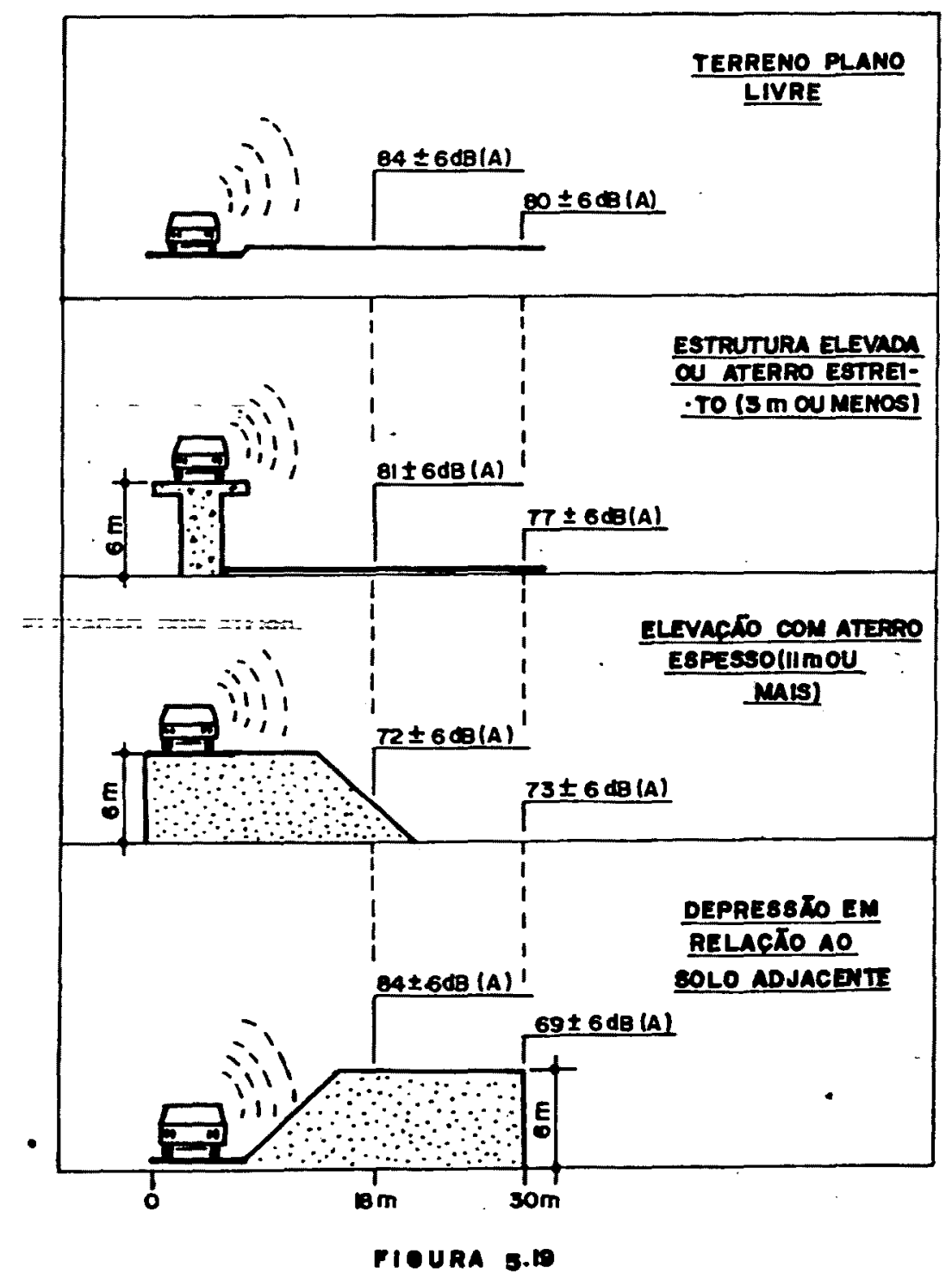

PROPABACT̃O dO SOM EN DIVERSAS 8ECÓES DE VIAS 
5.5 .2 .3 - Controle de ruídos de aeroportos

A poluição acústica resultante do trāfego aérec è um problema que tende a se agravar devido ao incremento desta forma de transporte, bem como por causa do crescimento rápido das áre as urbanas, com a consequente ocupação dos terrenos adjacentes aos aeroportos. Aeroportos construidos distantes dos centros ur banos são, em pouco tempo, envolvidos por edificações que ficam sujeitas a níveis elevados de ruídos, os quais tendem a aumentar com o crescimento do movimento de aviöes, para otender às neces sidades da população.

Há ainda a considerar o problema dos helioportos, os quais, devido äs facilidades će operação, aumentam nas grandes ci dades, gerando inümeros pontos emissores de barulho.

Faz-se necessāria a adoção de medidas visando contro lar esta modalidade de poluição. Como nos outros casos, os ruí dos podem ser combatidos através de medidas de controle nas fon tes de emissäo ou por tëcnices preventivas que garantam os ni veis de ruído adequados nas āreas sansíveis.

Algumas destas medidas são enumeradas a seguir:

(1) Reduçāo do barulho na fonte (prōprio aparelho) a travēs de exigências a serem cumpridas pelos fá bricantes e operadores de aviōes.

(2) Orientação das pistas e trajetōrias de aterragem e decolagem de modo a evitar a maior incidencia de ruídos nas äreas mais sensíveis.

(3) Disciplinamento do horārio de funcionamento do ae roporto, de forma a garantir o repouso da popula çāo no período noturno.

(4) Disciplinamento da localização de helioportos, proibindo-os nas proximidades de hospitais, esco las, casas de repouso, bibliotecas e outras at vidades.

(5) Construção de barreiras físicas contra a propaga çäo do som. Hestes casos, podem-se aproveitar con diçōes topogräficas ou outras características na turais para a criação destas zonas de isolamento. 
(6) Isolamento das edificações jä existentes nas äre as pröximas a aeroportos e afetadas pelo barulho. Exigências, atravēs do cōdigo de obras, para que as nov̈as edificações pröximas a aeroportos sejam construídas com dispositivos de isolamento contra ruídos.

(7) Disciplinamento do uso do solo da área em torno do aeropotto, de modo que os usos sensíveis à po luição acústica não fiquem nas zonas de ruídos mais intensos.

Esta ültima medida ē de grande importāncia pois, atra vës do planejamento adequado da localização do aeroporto e do uso das áreas adjacentes ao mesmo, pode-se controlar a poluição acústica, evitando-se níveis elevados de ruídos em algumas äre as.

E possivel determinar-se o impacto desum aeroporto existente sobre as äreas adjacentes, em termos de ruídos. Da mes ma forma, pode-se estimar este impacto no futuro, com a sua ex pansão, bem como prever-se os efeitos de um aaroporto a ser cons truído em determinado local.

A Administração Federal da Aviação, dos Estados Uni dos da América, utiliza um indicador do impacto de aeroportos so bre áreas adjacentes, em termos de ruídos, denominado de "Previ são de Exposiçäo ao Ruído" (Noise Exposure Forecast - N.E.F.)

o N.E.F. é um fator composto que comina numerosos as pectos de operação de um ceroporto e de seu impacto sobre äreas adjacentes, tais como: tipo de aviões, trajetörias de vôos, nüme ro de operaçōes por tipo, frequência e modelo de operação duran te as vinte e quatro horas do dia.

o N.E.F. é expresso por um nūmero e tem sido estabele cido nos Estados Unidos o seguinte critërio com relação as limi tes dos mesmos em função do uso do solo: N.E.F. igual ou superi or a 40, não aceitāvel para uso residencial; N.E.F. igual ou ín ferior a 30 , aceitävel para uso residencial; N.E.F. entre 30 e 40, è aceitável o uso residencial, com restriçōes. (54)

os pontos de mesmo N.E..F. em uma àrea adjacente e um aeroporto podem ser unidos em um gräfico, resultando num contor no que indica a zona sujeita aquele impacto. os valores mais al 
tos de ruídos ocorrem nas proximidades das trajetórias de aterra gem e decolagem. Deste modo, a forma deste contorno é, geralmen te, uma elípse estrelta e alongada.

Na FIGURA 5.20 apresentamos um exemplo de "Previsāo de Exposição ao Ruído" em um aeroporto, indicando dois contor nos, sendo o interno para N.E.F. igual a 40 e o externo para N.E.F. igual a 30 :

Assim, em um planejamento do uso das äreas adjacentes a este aeroporto, seria recomendado o uso residencial (e outros sensiveis) somente no exterior da linha de i.E.F. igual a 30 . En tre o aeroporto e este contorno (para N.E.F. superior a 30 ) pode riam ser definidos outros usos compativeis com o ruido mais in tenso, tals como: cinturōes verdes; uso agrícola, uso industrial e comercial, armazéns e depósitos, vias de acesso ao aeroporto, etc.

A determinação do H.E.F. é felta através de téćnica sofisticada geralmente não disponível na maioria dos aeroportos.

Mesmo não sendo possível determinações deste tipo, de ve-se planejar o uso do solo nas áreas adjacentes aos aeropor tos, principalmente nas zonas mais próximas das rotas de aterra gem e decolagem, estimando-se os impactos em termos de ruídos.

Assim, na definição de um local para construção de um aeroporto, devem ser considerados:

- Afastamento adequado das äreas residenciais e de ou tros usos sensíveis: superior a 2.000 metros, depen dendo do porte do aeroporto.

- Controle rigoroso do uso do solo nas proximidades, através de mecanismos legais que impeçam a ocupa ção, por residencias, das āreas afetadas.

- Definição de usos compatíveis, atravēs da elabora çäo de um Plano de Uso do Solo nas vizinhanças do aeroporto.

- Previsão de áreas para futuras ampliaçöes do aero porto, sem comprometer as zonas de proteção.

- Aproveitamento, se possível, das condiçōes topogrā ficas e outras caracteristicas naturais que dificul tem a propagação do som. 
- Estabelecimento, sempre que possivel, de rotas de decolagem e aterragem, de modo a preservar as äreas mais sensiveis.

A FIGURA 5.21 é um exemplo de disciplinamento do uso do solo visando preservar o impacto dos ruídos emitidos em um aeroporto, sobre áreas sensíveis. E claro que as soluçöes podem variar, dependendo das características locais. No entanto,o prin cípio é um só: afastar do aeroporto, o mäximo possível, as áreas sensiveis ao ruido intenso, através de um disciplinamento adequa do do uso do solo. Este controle deve ser mais rigoroso às már gens das rotas de aterragem e decolagem. 


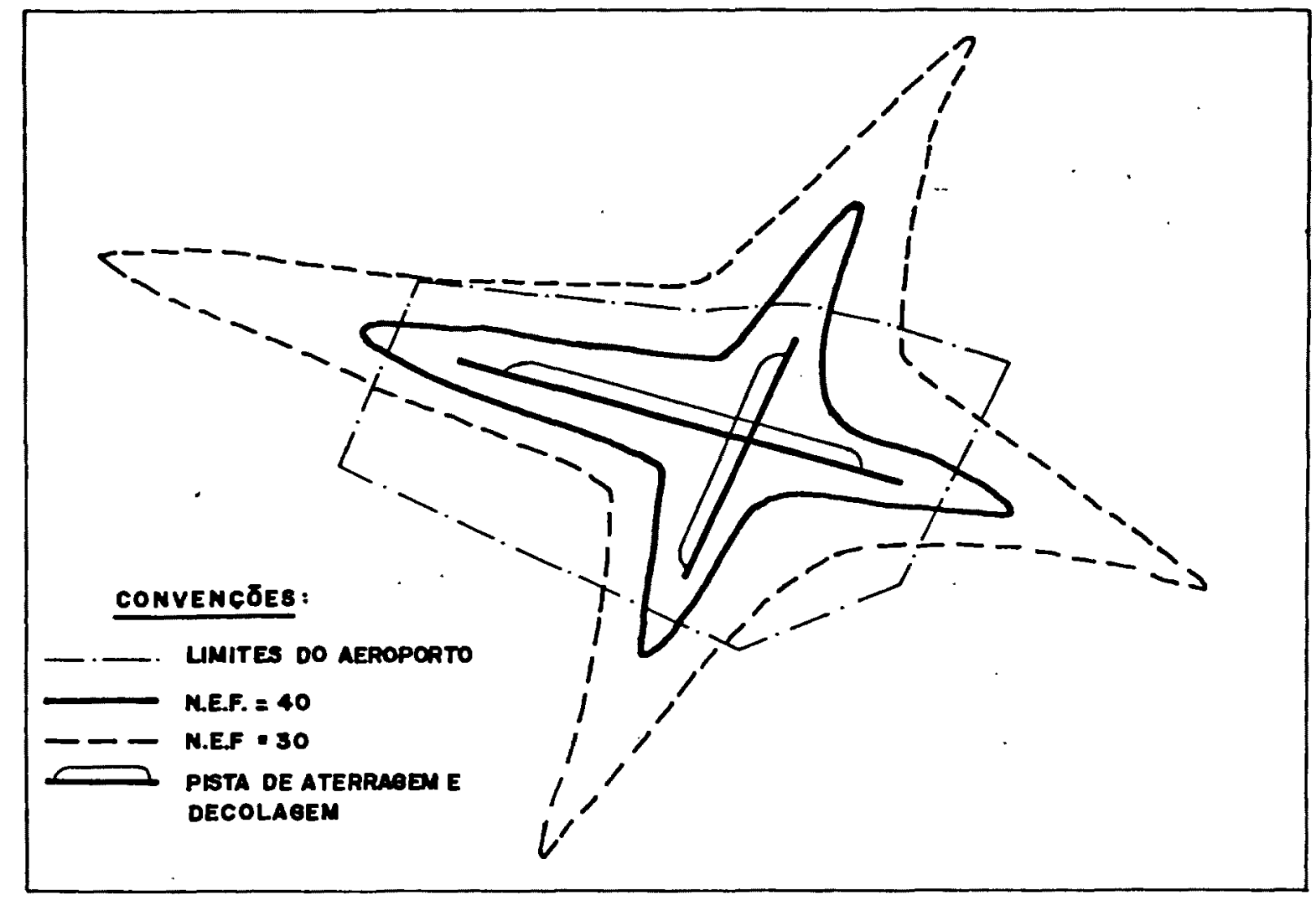

FIQURA 5.20

CURVAS DE "PREVISĀo DE EXPOSICĀO 10 RUÍDO (N.E.F. - " NOISE EXPOSURE FORECAST")

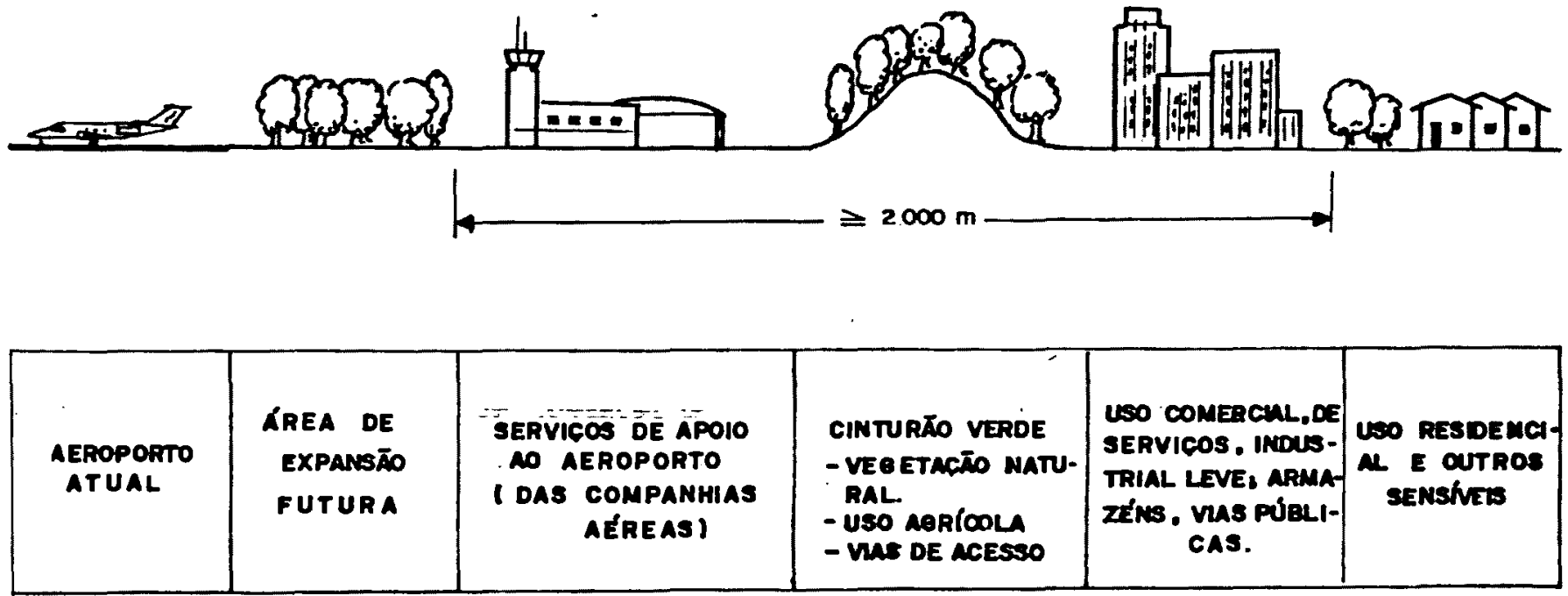

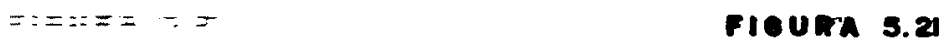

EXEMPLO DE DISGPURAMENTO DO USO DO SOLO NAS VIZINHANCAS DE UM AEROPORTO, VISANDO MINIMIZAR O IMPACTO DO RUIDO EM AREA8 SENSIVEIS 
5.6 - Uso do solo e controle dos recursos de valor paisagístico; ambiental e cultural

A ocupaçaื่o do solo urbano feita se ihtegrando ao ambi ente natural; e a manelra indicada para preservação da paisagem e, portanto, para o controle da poluição visual resultante da desfiguraçăo do meio urbano. .

Embora de caräter bastante subjetivo, é possível iden tificar-se áreas de grande valor paisagístico, as quais deverão ser ocupadas de forma planejada, aproveitando-se as caracteristi cas naturais do meio.

Sendo impossivel a desapropriação de todas estas äré as, a sua preservação é conseguida através do controle de sua cupação, fazendo-se com que isto ocorra de forma a causar o mín mo possível de desfiguração da paisagem.

E claro que as medidas de controle dependem,basicamen te, das características próprias de cada ärea a planejar. No en tanto, algumas medidas, de um modo geral, são aplicāveis em vá rias situações, entre as quais citamos:

(1) A disposição natural do solo deve ser mantida ao mäximo, pois os movimentos de terra - escavações e aterros - são, normalmente, acompanhados de des matamentos, muitas vezes daspojando o local de sua vegetação natural pröpria.

(2) As condiçōes naturais de drenagem das äguas devem ser mantidas, sempre que possível, pois, além das consequências indesejāveis, tais como a ocorrên cia de inundaçōes, estes cursos naturais de escoa mento, quando preservados, constituir-se-ão corre dores verdes de grande valor visual.

(3) A vegetação natural deve ser mantida, ou alterada - mínimo possível. Já enumeramos as diversas fun f̧ōes das àreas verdes em uma cidade. Aqui, acres centamos esta qualidade de grande valor visual proporcionado pelas mesmas. (FIGURA 5.22a)

(4) As construçōes, em locais de grande valor estēt co, devem ser feitas de modo a integrarem-se à 
paisagem, com taxas de ocupação bem baixas, garan tindo-sc, assim, grandes äreas livres. (FIGURA $5.22 a$ )

Uma forma de controle é permitir um maior adensa mento em zonas onde a preservaçāo não se faz ne cessäria, exigindo-se baixas densidades populacio nais - lotes grandes, com pequena taxa de ocupa ção - nas äreas a serem protegidas.

(5) Em terrenos acidentados, às vias püblicas devem ser construidas acompanhando o contorno natural do terreno, de modo a propiciar as vistas mais va riadas.

(6) As vistas püblicas devem ser mantidas, näo se per mitindo construçōes elevadas, em locais onde se pode desfrutar de uma bonita paisagem. (FIGURA $5.22 b$ )

Isto é conseguido proibindo-se construçōes em de terminados locais ou fixando-se alturas mäximas para as edificaçōes nestas äreas.

(7) Podem ser utilizadas elevaçöes naturais do terre no e recuos dotados de tratamento paisagistico,pa ra isolar.äreas residenciais de vias de grande mo vimento, atenuando-se assim, inclusive de modo psicolögico, os efeitos da poluiçäo do ar e acūs tica. Com isto, é mantida, tambëm, a privacidade das pessoas, isoladas pela barreira natural. (FI GURA $5.22 \mathrm{c}$ )

(8) Os equipamentos urbanos devem ser dispostos ade quando-se às características do meio e integran do-se, o māximo possível, à paisagem natural.

Reconhecemos ser bastante difícil o controle da polui ção visual, atravēs de regulamentação, pelas peculiaridades pró prias de cada local, bem como devido o caráter bastante sutjeti vo da mesma. No entanto, um planejamento urbano que considere es te aspecto pode, através de algumas medidas, contribuir para a preservação de äreas de valor paisagistico, evitando a sua des figuração. 

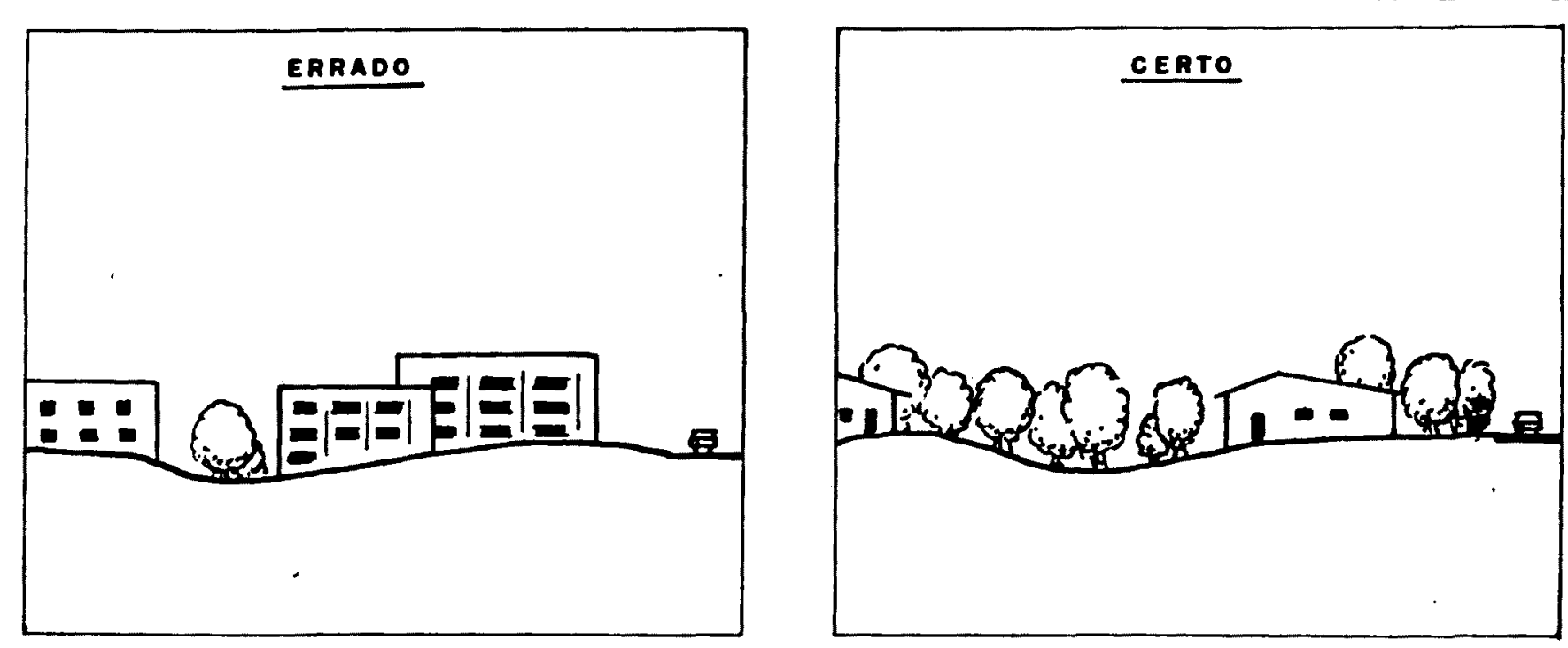

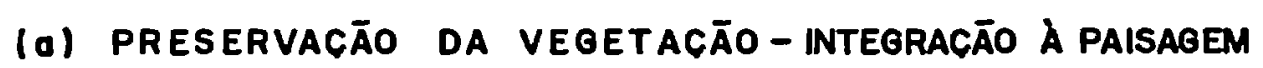
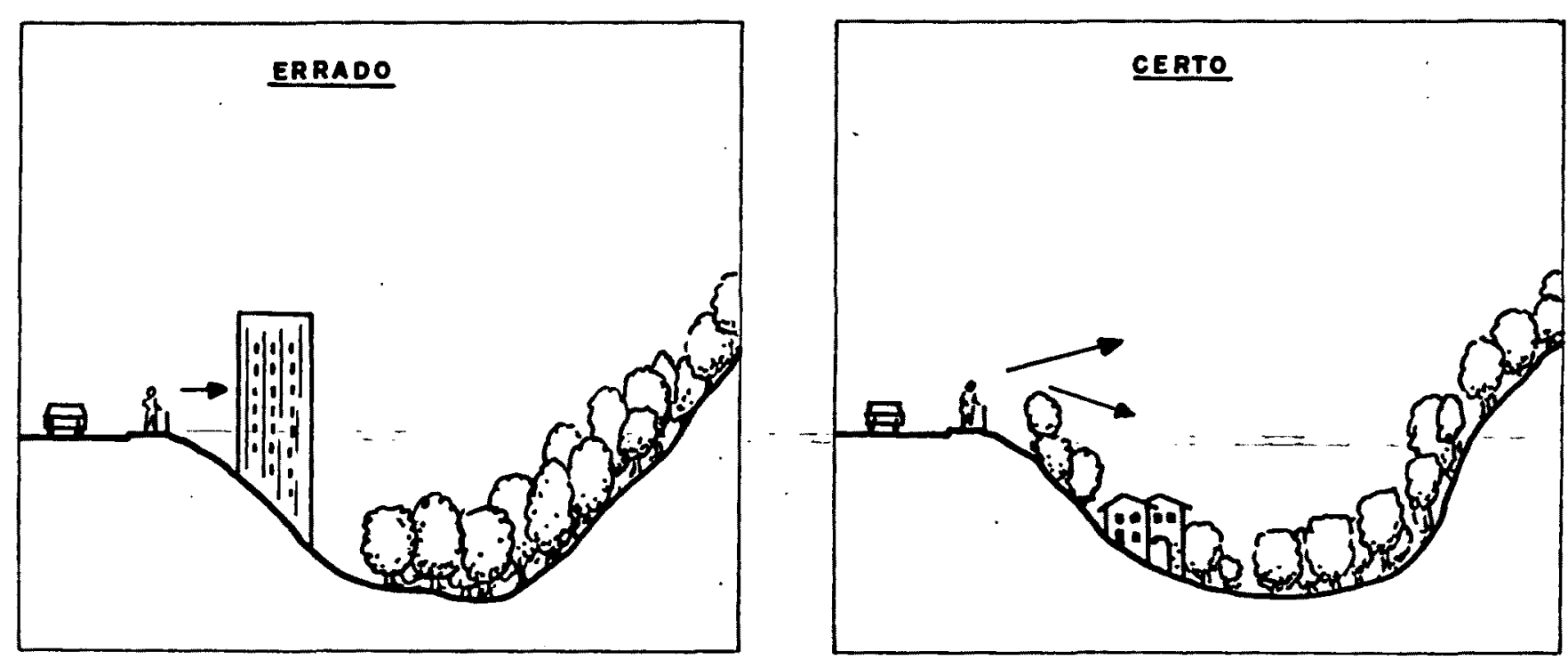

(b) PREservacāo de VSTAS públicas
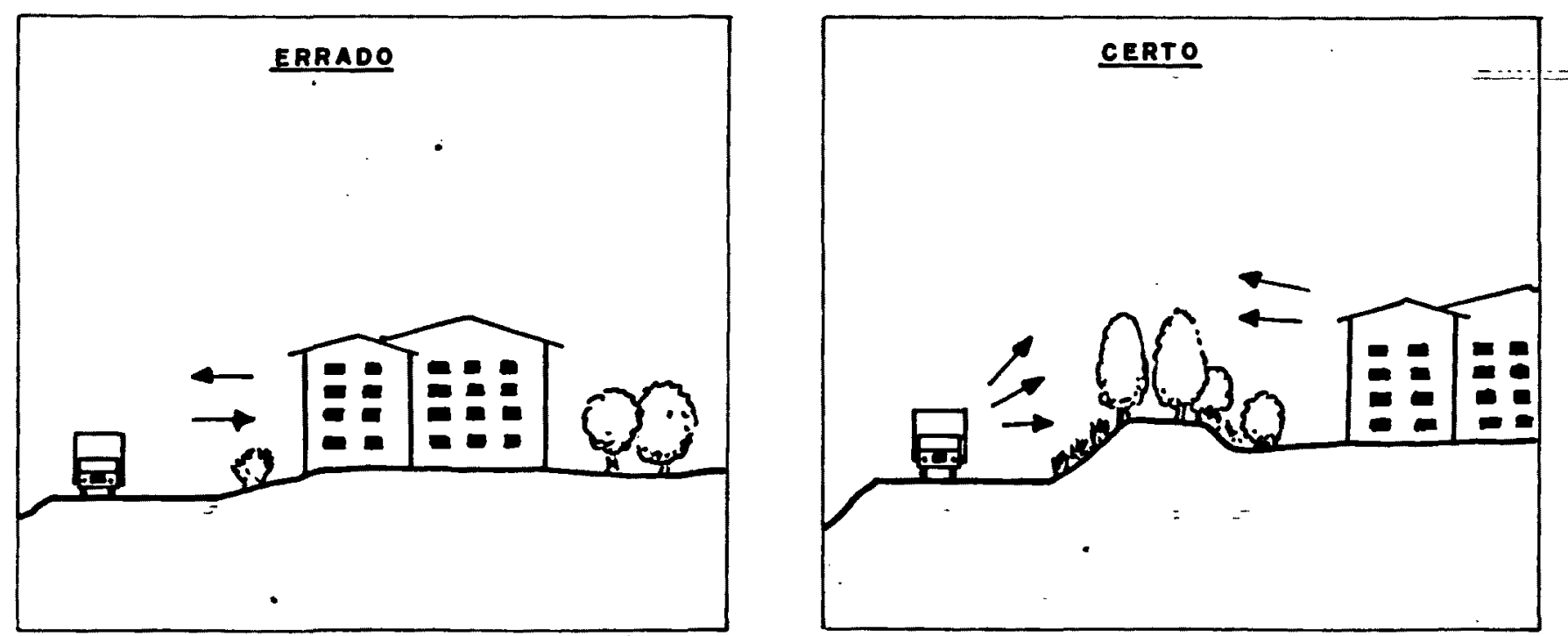

(c) Isolamento através de recursos paisagisticos

\author{
F I U R A 5.22
}

EXEMPLOS DE OCUPACŌES CERTAS E ERRADAS DO SOLO, EM TERMOS

DE A8PECTOS VIBUAIS 
São exemplos destas medldas:

- aquisição de ấreas para preservação.

- zoneamento, definindo estas äreas como locais de baixa densidade (baixas taxas de ocupação).

- legislação de controle da erosão, movimentos de ter ra, desmatamentos, e outras atividades correlatas.

- definição, quando da aprovação de loteamentos, das äreas a permanecerem livres e da distribuição dos lotes e vias püblicas.

- limitações em termos de altura das edificações.

- controle, na fase de aprovação de projetos, quando deverà ser exigida a manutenção, māxima possível, das características naturais do terreno.

A preservação da qualidade visual estä bastente asso ciada à proteção de algumas äreas com características prōprias, sob o ponto de vista ambiental e cultural. São recursos existen tes no meio urbano, naturais ou colocados pelo homem, os quais, pela grande importância dentro do meio, devemi ser preservados ou ocupados ordenadamente. Algumas destas äreas säo:

- coleções superficiais de ägua e respectivas äreas de inundaçöes

- äreas alagadas

- locais com vegetação intensa

- encostas

- äreas de recarga de aquíferos

- locais de valor histörico-cultural

- outros recursos naturais

Todas estas äreas devem ser identificadas e mapeadas, para fins de proteção. A FIGURA 5.23 é um exemplo de um mapa mos trando äreas de valor ambiental, sujeitas a disciplinamento ri goroso do uso do solo.

(a) Coleções superficiais de ägua e respectivas äreas de inundação 


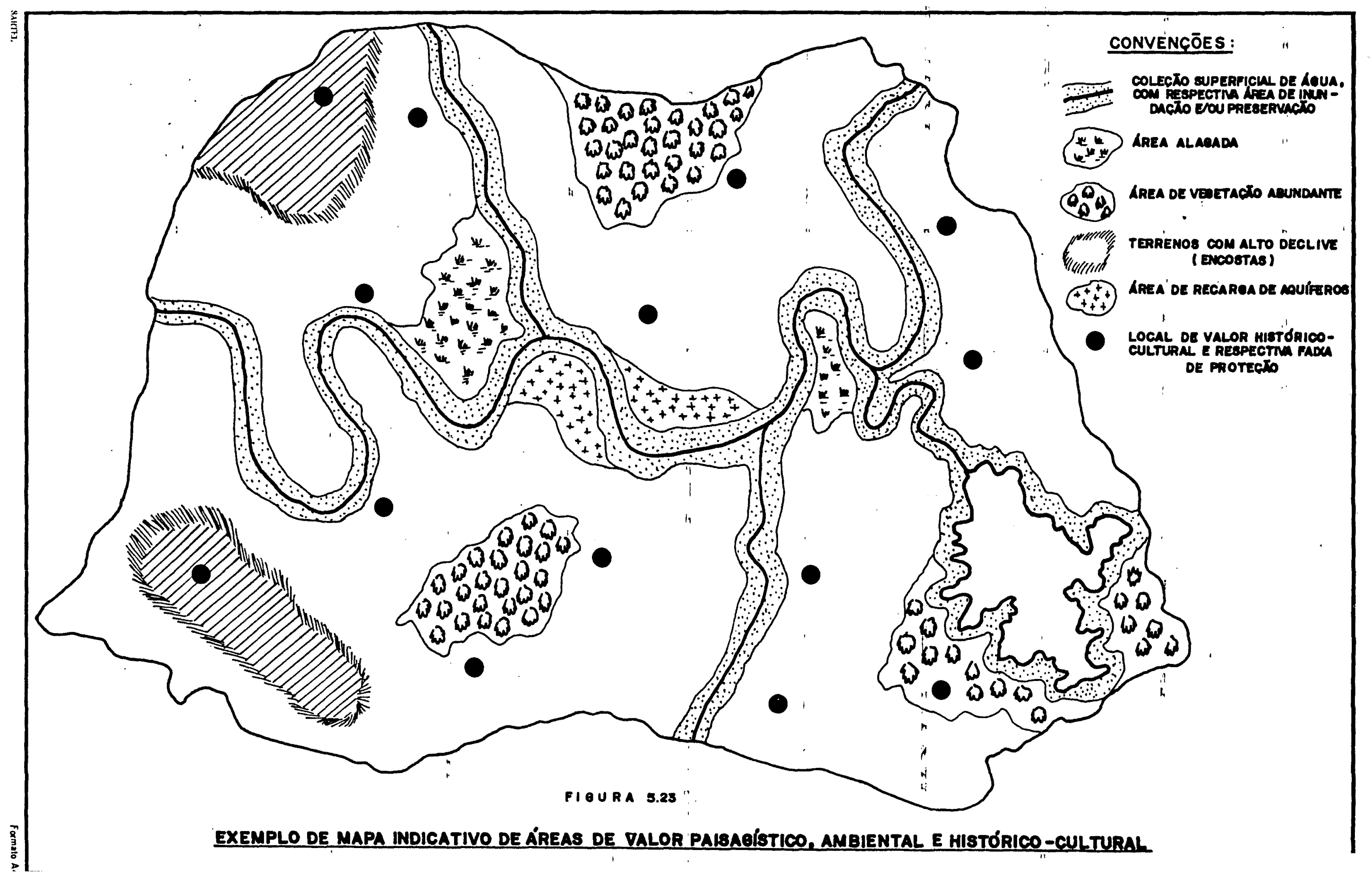


A preservação da àgua superficial e áreas adjacentes foi discutida no ítem 5.3.3. Conforme vimos, isto é conseguido a travēs de faixas de proteção e do disciplinamento do uso do so lo na bacla hidrográfica, principalmente nas proximidades das co leçõès de àgua.

(b) Areas alagadas

Os alagados ou pántanos, são, normalmente, āreas de baixa topografia, com drenagem precäria. Podem ser definidos co mo zonas de transição entre um terreno seco e uma coleção super ficial de àgua.

Estas āreas podem ter grande valor natural, sendo al gumas de suas funções:

- afetam a qualidade da coleção de água adjacente, pois retèm as impurezas das àguas de escoamento an tes que elas alcancem as formaçöes hidricas superfi ciais.

- moderam o fluxo d'água do escoamento superficial, funcionando como controladoras de inundaçōes.

- tèm papel ecológico importante pois proporcionam condições de vida para variadas espécies de vege tais e animais.

- funcionam como áreas de recarga ou descarga do len f̧ol freàtico.

A preservação de uma ārea deste tipo é conseguida a travēs da aquisição total da mesma, o que nem sempre é possível, ou por meio do disciplinamento do uso do solo, inclusive nas su as märgens. Conforme vimos anteriormente, esta ärea pode ser in cluída dentro da faixa de preservação, de largura variável, de re cursos hidricos superficiais, conforme indicado no item 5.3.3.1.

os usos recomendados para estes locais são: práticas de conservação; proteção de espëcies de valor ecológico; recrea ção; ancoragem de barcos; operação de barragens e outros dispos tivos de controle da àgua; algumas atividades agricolas, pasta gens e jardinagem..

(c) Âreas de vegetação 
Jä mostramos, por diversas vezes, a importância da ve getação no meio ambiente. Além de tudo isto, ela representa im portante papel do ponto de vista paisagistico.

Associando-se as äreas verdes com outras finalidades; taís como a recreação, proteção da erosão, preservação das măr gens de recursos hídricos, barreiras contra a poluição do ar, e acüstical corredores de circulação do ar, entre outras, pode-se dotar um meio urbano de grandes āreas com végetação, de excelen te valor estêtico:

Quando não for possível a desapropriaçăo destas äre as, o disciplinamento do uso do solo será a ferramenta mais ef ciente para a sua preservação.

os usos recomendados pâra estas äreas são: conserva ção; estudos e pesquisas ecológicas; recreação ativa ou passiva; composição de paisagem; uso agrícola, sem grandes desmatamentos; edificações, com baixa taxa de ocupação: no mäximo igual a 0,20 , devendo o restante da área permanecer na condição natural.

\section{(c) Encosicas}

No ítem 5.2.2 indicamos diversas medidas de planeja mento do uso do solo visando a proteção da erosão em terrenos com alta inclinação. A adoção das mesmas contribui consideravel mente para a preservação do paisagem natural.

Assim, a proteção destas āreas é conseguida atravēs do uso adequado do solo, sendo recomendados: vegetação; áreas de recreação; ou ocupação a baixas densidades, variávels com a in ciinação do terreno. (Ver FIGURA 5.3).

(e) Areas de recarga de aquíferos

Um aquífero è recarregado a partir de outros aquife ros adjacentes ou pela infiltração da ägua de superficie, oriun da de coleções superficiais, de alagados, ou da precipitação plü viomētrica.

Podem ser identificadas zonas de terreno por onde é feita a infiltração da āgua a partir da superfície, as quais são chamadas de "äreas de recarga de aquíferos".

o processo de urbanização pode causar a impermeabil zação destas äreas, devido às construções e pavimentações, redü zindo, portanto, a quantidade de àgua infiltrāvel. 
Assim, no planejamento do uso do solo devem ser iden tificadas as äreas de recarga dos aquíferos de utilização poten cial, as quais devem ser tratadas adequadamente. Huitas vezes,es tas āreas coincidem com as zonas de inundações adjacentes aos re cursos hídricos superficiais. Porēm, nem sempre isto acontece, havendo necessidade do conhecimento geológico do local.

A melhor forma de proteger äreas de recarga de aquife ros è mantê-las livres, totalmente ou em grande parte.para isto, as mesmas devem ser destinadas a usos leves, com baixa ocupaça: äreas de recreação; trechos de composiçäo paisagística; ou usos com baixa taxa de ocupaçāo - no māximo igual a 0,10 .

(e) Locais de valor histórico e cultural

Em um programa de promoção da qualidade íisual de um centro urbano, devem ser identificados e preservados os locais de valor histórico e cultural: monumentos histōricos;edificaçōes de valor patrimonial; äreas da ocorréncias histöricas; estrutú ras artísticas, etc.

Estes locais, associados aos demais elementos paisa gísticos de uma cidade, comporão, em conjunto, os recursos visu ais que constituirão a beleza do meio.

Muitas vezes, alēm da edificação em sí, devem ser pre servadas áreas em torno das mesmas, de modo a garantir sua prote ção e ressaltar suas qualidades visuais. Estas faixas de prote f̧ão devem ser definidas em acordo com os örgãos responsäveis pe la administração do patrimônio histórico.

\section{(f) outros recursos naturais}

Alêm dos recursos naturais já citados, outros podem ser incluídos em um programa de preservação ou ocupação ordena da: dunas, estuärios, mangues, etc. Cada local tem as suas carac terísticas naturais próprias, cabendo ao planejador definir as medidas visando a sua preservação. 
6. Metodologia de Planejamento Urbano visando a preservação do meio ambiente

6.1 - Etapas dó plánejamento

o planejamento urbano visando a preservaçä́o do meio amblente deve, obviantente, segulr a mesma sistemātica da planifi cdçăo, destenvolvendo-se através de diversas fases, desde o diag nōstico atē a implantação e avaliação.

No entanto, énfase maior deve ser dada aos aspectos ambientais, através do levantamento das características naturais da ärea em estudo, da situação existente em termos de qualidade ambiental e da estimativa dos possíveis impactos sobre o ambien te, tudo dentro de uma sistemätica de preservação.

o planejamento deve compreender, então, as seguintes

fases :

(1) - levantamento de dados

(2) - DIAGNOSTICO

(3) - FORMULAÇÃO DE OBJETIYOS

(4) - elaboraçāo de plano de uso do solo

(5) - EXECUÇĀO

(6) - AVALIAÇ̃̃̃O

A primeira etapa, do LEVANTAMENTO DE DADOS, compreende a coleta de informações sobre a situação existente da àrea de es tudo, devendo constar de:

a) Condições climäticas

- Precipitação

- Insolação

- Direção e velocidade dos ventos

- Condições das camadas atmosfëricas

b) Topografia

- Levantamento plani-altimétrico

- Declividade dos terrenos

- Posição de vales e elevações 
c) Geologia

- Tipos de solo

- Característ cas dos solos: permeabilidade, po rosidade

- Níveis do lençol freātico

- Solos problemas

d) Hidrologia

- Recursos hídricos superficiais

- Recursos hídricos subterrāneos. àreas de re carga

- Estudos de bacias hidrogräficas

- Alagados, pãntanos, mangues, etc.

- Ciclo hidrolögico

- Orenagem

- Áreas sujeitas a inundaçōes

e) outros recursos naturais

- Vegetação

- Areas de valor ecológico

- Areas da valor paisagístico

f) Locais de valor histórico-cultural

g) Qualidade ambiental existente

- Condiçöes de poluição. Levantamentos de àreas críticas

- Padrōes de qualidade ambiental

- Legislaçōes em vigor

h) Infra-estrutura sanitäria existente e/ou projetada

- Abastecimento de ägua

- Coleta e tratamento de esgotos domésticos e industriais

- Coleta, transporte, tratamento elou destino final dos resíduos sölidos

- Drenagem de āguas pluviais

i) Uso do solo existente e/ou projetado

- Zoneamento

- Lei de loteamento. Loteamentos jā aprovados

- Planos Diretores

E óbvio que muitas outras informaçōes sāo necessärias 
para o planejamentó de uma ărea urbana, conforme pode ser cons tatado nas publicacōes específicas sobre o assunto. Aqui, desta camos apenas os dados que interessam ao planejamento visando a preservação ambiental. Mesmo sob este aspecto, muitas outras in formaçōes poderăo ser necessārias, dependendo de cada caso espe cífico, ajustando-se às circunstāncias físicos, económicas, soci ais e políticas do local.

A partir dos dados coletados é feito o DIAGNOSTICO da situação existente, o qual, sob o nosso aspecto de interesse, de ve avaliar as condiçōes ambientais, identificando:

- Areas consideradas próprias ou impróprias para ocu pą̧ão urbana.

- Condições de poluição: características dos recursos hídricos, comparadas com os padrōes jā estabeleci dos ou desejados; classificação dos corpos d'água; teores de poluentes atmosfēricos; niveis de ruídos; poluição visual.

- Principais fontes de poluição do solo, ar, āgua, a cūstica e visual.

- Recursos naturais jā sujeitos a degradação

- Iaentificação dos usos de maiores impactos ambientais.

- Necessidades básicas, em termos de infra-estruturasanitäria.

- Areas de possível expansão da cidade. Loteamentos jä aprovados.

- Barreiras ao crescimento da cidade, incluindo limi taçōes naturais e limitaçōes impostas pelo homem.

Depois do diagnóstico segue-se a fase de FORHULAção DE OBJETIVOS, na qual serão definidas as metas a serem alcanca das, tais como:

- Areas a serem ocupadas por usos urbanos.

- Recursos que deverão ser preservados.

- Areas a serem atendidas por infra-estrutura sanita ria. 
- Padrões de qualidade ambiental a serem alcançados.

- Usos indicados para as diferentes zonas, em função das características ambientais das mesmas.

- Intensidade de ocupação de cada zona

- Legislaçōes de controle ambiental a serem elabora das.

A fase seguinte è a de ELABORAÇÃO dO PLANO DE USO DO SOlo propriamente dito. Nesta etapa, serão definidos os mecanis mos para que sejam alcançados os objetivos estabelecidos previa mente.

De um modo geral, podemos dizer que o Plano deve defi nir os diferentes usos do solo urbano, em função das caracterís ticas dos recursos naturais e de modo a causar o menor impacto possivel sobre as äreas mais sensiveis ao processo de urbaniza ção e/ou de maior valor ambiental. Deve estabelacer as diversas técnicas e os parâmetros urbanísticos a serem aplicados para a cançar estes objetivos.

o Plano de uso do Solo deve considerar, além dos as pectos ambientais, o relacionamento dos mesmos com os fatores conōmicos, sociais e políticos, de mudo a não se dissoclar da realidade do local.

Passa-se, entäo, à fase de ExeCuçăo do Plano, a qual deve ser permanentemente acompanhada de AVALIAÇÃo, para adoção dos ajustes que se fizerem necessärios.

Nenhum plano deve ser um instrumento rigido, mas sim, flexível, de modo a adaptar-se às circunstancias imprevistas na fase de elaboração do mesmo.

A avaliação deverā ser contínua e, a partir dela, se rão processadas mudanças nas outras fases anteriores do planeja mento.

A FIGURA 6.1 mostra, de forma resumida, as diversas etapas do planejamento do uso do solo urbano visando a preserva ção do meio amíiente. 


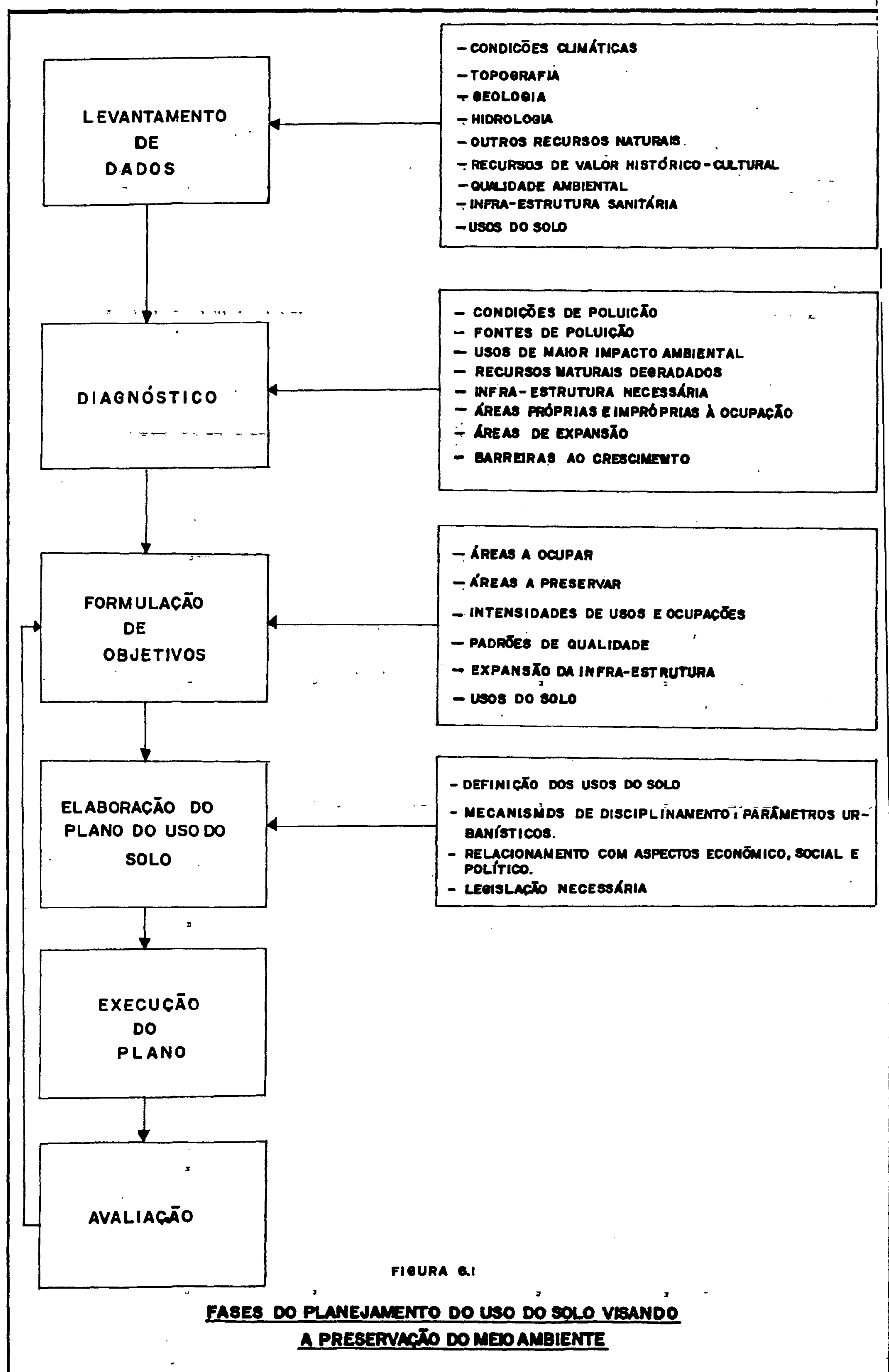


6.2 - Sistemātica de controle

6.2.1 - Aspectos legais e institucionais

De acordo com HELY LOPES MEIRELLES, a preservaçāo dos recursos naturais pode ser feita atravës de dois modos: pelas 1 mitações administrativas de uso do solo, ou pela desapropriação.

Diz o referido autor:

"A preservação dos recursos naturais, assim en tendidos todos os elementos da Natureza que mantêm o equilíbrio ecológico e a vida em nosso planeta, è de ver do Estado e apoia-se no domínio eminente que ele exerce scure todas as coisas que se encontram em seu território. Mas, como domínio eminente não é domíniopatrimonial, o Estado não tem o direito de proprieda de sobre todos os bens de seu territörio, podendo ape nas condicionar o uso da propriedade particular para cumprimento de sua função social (Constituição da Re püblica, art. 160, 111$)$, ou retirä-la compulsoriamen te je seu dono, por utilidade püblica ou interesse so cial, atravēs de desapropriação, com justa e prévia indenização (art. 153, \$22)".

"Assim, a preservação dos recursos naturais se faz por dois modos: pelas limitações administrativas de uso, gerais e gratuitas, sem impedir a normal ut lizaçāo econômica do bem, nem retirar a propriedade do particular, ou, pela desapropriaçāo, individual e remunerada de determinado bem, transferindo-o para o domínio püblico e impedindo a sua destruição ou de gradação". (33)

o disciplinamento do uso-ocupação do solo $\vec{e}$, de modo geral, de competência dos três níveis de governo: federal, esta dual e municipal.

A Constituição do Brasil estabelece como de competen cia da União: executar planos regionais de desenvolvimento;legís lar sobre a preservação ou recomposição da vegetação e da estabi lidade das encostas, bem como sobre jazidas, minas e outros re 
cursos naturais; proteger os locais de valor histōrico ou artís tico, os monumentos e paisagens naturais e as jazidas arqueológ cas.

Em. termos de preservação do meio ambiehte, o DecretoLei federal n\$ 1413, de 14 de agosto de 1975, dispöe sobre o con trole da poluição do meio ambiente provocada por atividades ín dustriais, obrigando as indústrias instaladas ou a se instalarem no territorio nacional a promover as medidas necessarias a preve nir ou corrigir os incoveniantes e prejuízos causados pela polu ção.

A Secretaria Especial do Meio Ambiente - SEMA, subordi nada ao Ministērio do Interior, foi criada em 1973, visando a conservação do meio ambiente e o uso racional dos recursos natu rais. Este örgāo jā elaborou algumas legislaçōes de preservaçāo e controle da poluição, estabelecendo padróes de qualidade do ar e da água e, de alguma forma, influindo no disciplinamento do uso do solo. (35)

A SEMA elaborou, também, legis lação visando controlar a poluição causada pelos resíduos sölidos, através da portaria n? 053, do Ministērio do Interior, de 01 de março de 1979.

outro controle a nível federal é o das bacias hidro gräficas, as quais, muitas vezes, são constituídas por äreas de diversos Estados.

A administração integrada de bacias hidrogräficas vem sendo feita, jä hä algum tempo, em alguns países desenvolvidos. relacionando o uso da àgua com o do solo.

No Brasil, este controle è recente e somente a par tir de 1979 foi instituído o Comitê Especial de Estudos Integra dos de Bacias Hidrográficas, visando acompanhar o planejamento físico e propor medidas disciplinadoras do uso do solo e da água nessas àreas. Alguns Comitês Executivos, a nível de cada bacia hidrográfica, encontram-se implantados, tais como os das Bacias do Paraíba do Sul, Paranapanema, Guaíba e Jari.

Consideramos da maior importância este disciplinamen to, de forma Integrada, das bacias hidrogräficas, pois sabemos que a qualidade da àgua de um recurso hídrico depende, basicamen te, do uso do solo na ärea de sua bacia.

Mais recentemente, foi sancionada a Lei Federal no.. 6.766 , de 19 de dezembro de 1979, dispondo sobre o parcelamento 
do solo urbano: A seguirir, destacamos alguns aspectos da referida legis laçāo:

(1) Näo será permitido o parcelamento do sclo:

a) em terrenos alagadiços e sujeitos a inundaçōes, antes de tomadas as providencias para assegu rar o escoamento das äguas;

b) em terrenos que tenham sido aterrados com mate rial nocivo à saúde püblica, sem que sejam pre viamente saneados;

c) em terrenos com declividade igual ou superior a $30 \%$, salvo se atendidas exigencias especifi cas das autoridades competentes;

d) em terrenos onde as condições geológicas não aconselham a edificação;

e) em äreas de preservação ecolögica ou naquelas onde a poluição impeça condiçōes sanitárias sü portāveis, até a sua correçäo.

(2) Ao longo das äguas correntes será obrigatório a reserva de uma faixa non aedificandi de 15 (quin ze) metros de cada lado, salvo maiores exigências da legis lạ̧ão específico.

(3) A percentagem de āreas püblicas destinadas a sís temas de circulação, de equipamento urbano e co munitärio, bem como a espaços livres de uso pübli co, será proporcional à densidade de ocupaçăo pre vista para a gleba, não podendo ser inferior a $35 \%$ da gleba, salvo nos loteamentos destinados ao uso industrial cujos lotes forem maiores de .... $15.000 \mathrm{~m}^{2}$, caso em que a percentagem poderā ser re duzida.

(4) Caberāo aus Estados o exame e a anuēncia prēvia para a aprovação, pelos llunicipios, de loteamento e desmembramento nas seguintes condiçōes:

a) quando localizados em äreas de interesse espe cial, tais como as de proteção aos mananciais ou ao patrimonio cultural, histórico, paisagís 
tico e arqueolōgico, assim definidas por legis lação estadual ou federal;

b) Quando o loteamento ou desmembramento local zar-se em área limitrofe de municiplo ou que perteriça a mais de úm município, nas regióes metropolltatias ou em agremlaçöes urbanas; def $I$ nidas em lei estadual ou federal;

c) quando o loteamento abranger àrea superior a um milhão de metros quadrados.

No caso de loteamento ou desmembramento localizado em ärea de municipio integrante de regiāo metropolitana, o exame e a anuência prévia à aprovação de projeto caberá à autoridade me tropolitana.

Como vemos, a Lei Federal n? 6.766 dispöe sobre o par celamento do solo urbano, atribuindo malor competêncla aos Esta dos, principalmente nos casos de äreas especiais de proteção. E, sem düvida, um instrumento legal eficiente que os Estados e Muni cípios dispõem para preservar áreas de valor ambiental,cultural, histórico, paisagístico e arqueológico.

De acordo com a referida Lei, os Estados, o Distrito Federal e os Municíplos poderão estabelecer normas complementa res relativas ao parcelamento do solo municipal para adequar o previsto nesta legislação às peculiaridades regionals e locais.

A competência estadual de legislar sobre o uso do so lo ganhou maior amplitude a partir da Lei Complementar Federal n? 14, de 08 de junho de 1973, a qual considerou como interesse metropolitano alguns serviços comuns aos municípios que integram cada regiāo, entre os quais: o uso do solo metropolitano; o pla nejamento integrado do desenvolvimento económico e social; o a proveitamento dos recursos hídricos e controle da poluição ambi ental, na forma que dispuser a lei federal.

Com base nesta lei, alguns Estados brasileiros já le gislaram sobre o uso do solo visando a preservaçäo dos recursos hídricos, em äreas metropolitanas. Já foram, tambēm, aprovadas leis sobre zoneamento industrial.

observa-se uma tendência de aumentar a competência da Uniăo e dos Estados no controle do uso do solo,principalmente vi 
sando a preservação ambiental.

No entanto, ainda é muito ampla a competencia munici pal de disciplinamento do uso-ocupação do solo. A definição do zoneamento, o controle especifico do parcelamento do solo, bem como a fixação de parâmetros urbanísticos - tais como dimensões mínimas de lotes; recuos; indices de aproveltamento, ocupação e elevação; porcentagens de āreas livres ou destinadas a usos comu nitārios, entre outros - são atribuiçóes pröprias da esfera mu nicipal.

De modo geral, as legislaçōes de disciplinamento de uso-ocupação do solo, a nível dos municípios, podem representar importante papel na preservação do meio ambiente urbano.

Conforme já dissemos, o melhor disciplinamento do uso do solo é aquele que considera os aspectos ambientais, apoiandose em princípios de saneamento.

Desta forma, o örgão de planejamento e controle do uso do solo urbano deve trabalhar de forma integrada com o res ponsável pela preservação e controle do meio ambiente, tendo, am bos, o mesmo objetivo final:a melhor qualidade de vida.

Estes dois organismos se integrarão aos outros respon säveis pelos serviços püblicos da cidade. (FIGURA 6.2)

Alguns exemplos da necossidade deste Interrelacionamento podem ser citados:

- Os serviços de infra-estrutura sanitäria devem ser usados como limitantas ou impulsionadores do desen volvimento de determinada área, cabendo ao órgão de planejamento, em comum acordo com o de preservação ambiental, definir os locals mais propícios à ocu pação urbana.

- A localização de um aterro sanitārio ou de outra instalação para tratamento elou destino final do li xo deve ser feita levando em conta aspectos de pre servação da qualidade do meio e fatores urbanísti cos, entre outros.

- o ordenamento do sistema de transportes consideran do aspectos ambientais é uma medida importante no controle da poluição do ar elou acüstica. 


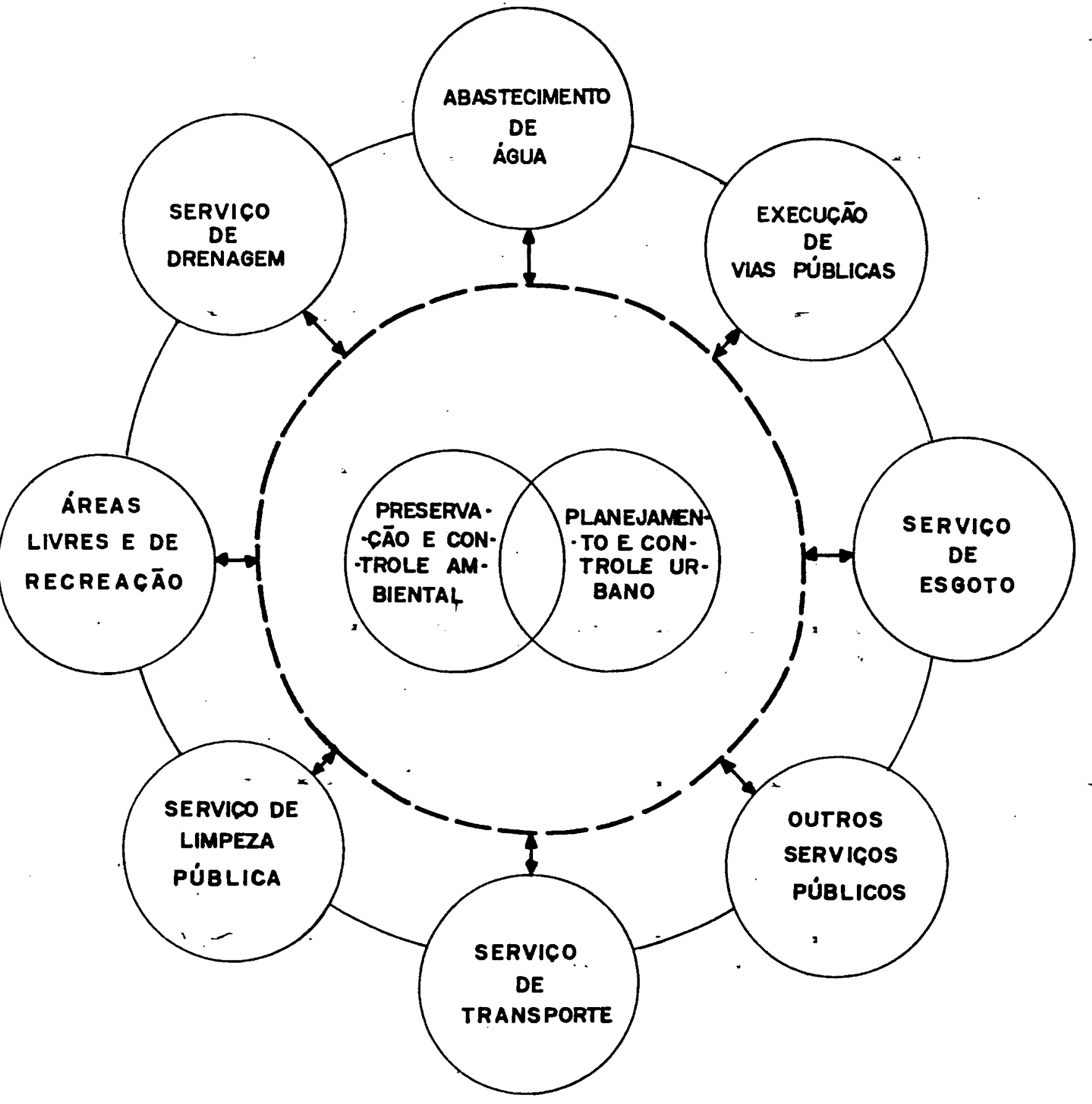


- A abertura de vias, induzindo à expansāo da cidade em determinada di reção e contribuindo para o aumen to do träfego em uma ārea, sō deve ser feita após analisados os impactos ambientais resultantes.

- Um sistema de äreas livres pode ser disposto em uma zona urbana associado js medidas de isolamento de äreas elou dispersão de poluentes.

Alēm destas situações, muitas outras já foram discut das durante todo o texto deste trabalho, quando procuramos mos trar a importáncia deste relacionamento entre os örgãos de plane jamento, controle ambiental e de serviços püblicos.

Visando garantir esta perfeita integração, è recomen dävel a organização de um Conselho Consultivo de Preservação Am biental, composto de representantes dos diversos órgãos, o qual serla responsável pela definição das normas e objetivos a serem alcançados no trabalho conjunto.

6.2 .2 - Técnicas de controle

o planejador e/ou responsāvel pela preservação do meio ambiente dispōe de alguns mecanismos para disciplinar o uso ocupação do solo dentro deste enfoque de conservaçāo ambiental.

A seguir, comentaremos algumas destas tëcnicas:

a) Plano de Proteção Ambiental

- lano de Proteção Ambiental constitui o elemento mais amplo, devendo conter os objetivos gerais e servir como guia para as demais medidas a serem adotadas.

No Plano, devem ser identificados os fatores limitan tes à urbanização, sejam de carāter natural ou impostos pelo ho mem.

Os fatores limitantes naturais são as áreas com carac terísticas ambientais mais sensiveis ao processo de urbanização, as quais devem ser preservadas ou ocupadas de forma mais contro lada.

As dificuldades impostas pelo homem são os serviços de usos comanitärjos, tais como os sistemas de infra-estrutura - 
urbana, os quais, quando não são disponiveis, podem ser conside rados como fatores limitantes do desenvolvimento.

A identificação das äreas ambientais sensíveis ao pro cesso de urbanização pode ser feita através do Mëtodo de Super posição de Mapas. Esta técnica consta do seguinte: (FIGURA 6.3)

- Em papel transparente, traçam-se diversos mapas, on de sāo identificadas, atravēs da intensidade do som breamento, as äreas onde o impacto da urbanização $\bar{e}$ MAIOR, MEDIO E MENOR. Para cada tipo de caracterís tica è elaborado um mapa.

- Os mapas são superpostos um sobre os outros, resul tando em um mapa composto, onde são identificadas desde as äreas mais críticas (sombreamento mais es curo) atē as āreas menos sensíveis (äreas em bran co na FIGURA 6.3).

Todas as äreas consideradas sensiveis, do ponto: de vista ambiental, devem ser mapeadas:

- Areas de vegetação intensa

- Zonas de valor ecológico

- Locais de valor paisagístico (visual)

- Coleções superficiais de āgua e àreas de inundaçōes correspondentes.

- Terrenos com inclinações elevadas

- Alagados, estuärios, mangues e outros

- Areas de recarga de aquíferos

- Terrenos não apropriados para uso de fossas sēpti cas (onde não existe sistema de esgoto)

- Solos não recomendados para construções

- Locais de valor histōrico-cultural

o mapa composto, resultante da superposição dos de mais, indicará as zonas onde o desenvolvimento poderá ser mais intenso (ärea em branco), onde algumas restriçōes deverão ser feitas (ärea hachuriada clara) e os locais a serem preservados ou ocupados com maiores restriçōes (ärea hachiriada escura). 


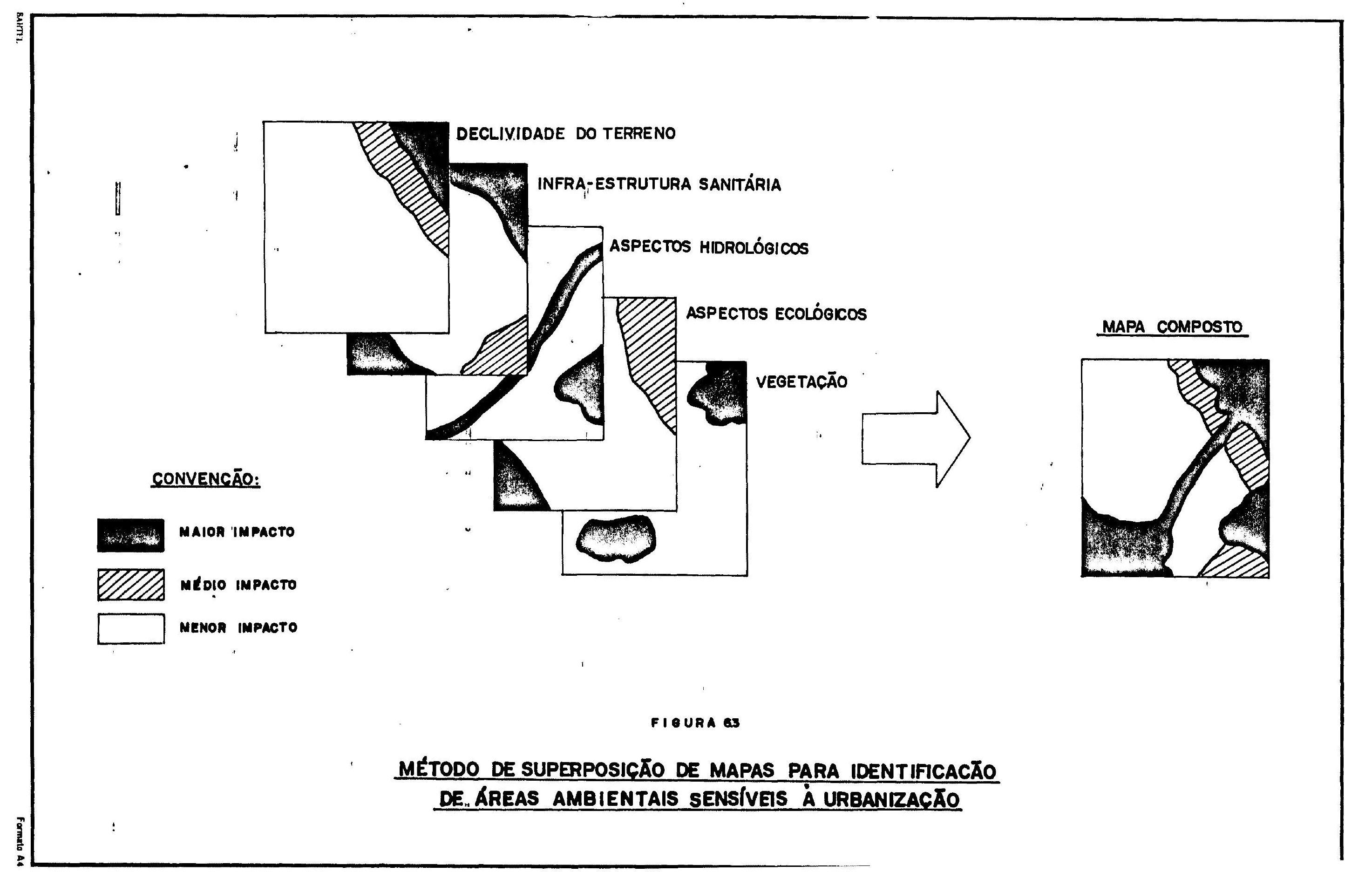


Este mapa auxilia bastante no estabelecimento do zo neamento, o qual deve ser feito em função da capacidade do meio de acomodar determinadas intensidades de ocupação dos diversos usos do solo.

Isto é o que chamanos de "capacidade natural de utili zação" de determinado meio e a mesma deve ser respeitada, para evitar degradaçöes ambientais.

- Plano de Proteção Ambiental deverä ldentificar, tam bēm, os usos que mais contribuem para alterações ho meio, tais como:

- Atividades poluidoras do ar: möveis e estacionárias

- Fontes de ruídos: veículos, aeroportos, equipamen tos, etc.

- Grandes contribuidores de resíduos líquidos, domés ticos ou industriais

- Sistemas de tratamento de esgoto e de dispusição de lodos

- Sistemas de tratamento e/ou destino final dos resí duos sölidos

- Desmatamentos

- Movimentos de terra

- Lançamento de esgoto no sub-solo

Estas atividades devem ser compativeis com os ambien tes onde deverão ser exercídas, respeitando as suas característi cas naturais, Para isto, o Plano, com tase no conhecimento deta lhado da situação, definirä os objetivos a serem alcançados e os mecanismos de ação necessärios para que isto ocorra.

o objetivo principal é preservar ou ocupar adequada mente as äreas de significação ambiental. Alguns mecanismos para conseguir esta meta seräo discutidos a seguir.

b) Zoneamento

A definição dos usos adequados, inadequados, ou ade quados com restrições, para as diferentes zonas de uma àrea urba na, constitui uma das importantes ferramentas para o disciplina mento do uso-ocupação do solo. 
Com vistas à preservação ambiental, o zoneamento deve ser feito com base nas caracteristicas do meio, considerando a "capacidade natural de utilização" dos recursos disponíiveis.

A partir da identificação das äreas mais apropriadas e das mals sensíveis à urbanização (FIGURA 6.3), serão definidos os vários usos para as diversas zonas e estabelecidos indices ur banisticos para ocupação das mesmas.

A distribuição dos usos e respectivos indices urbanís ticos será feita considerando aspectos ambientais, tais como:

- Quallidade ambiental existente

- Capacidade do meio de dispersar e depurar poluentes

- Posição das atividades poluidoras em relação aos sos mais sensiveis

- Importāncia do meio, do ponto de vista ecológico, paisagistico ou histórico-cultural

- Padrões de qualidade já definidos ou propostos (qua lidade ambiental a alcançar)

- Interrelacionamento das caracteristicas ambientaiscom os aspectos económicos, sociais e políticos.

São exemplos de índices urbanísticos visando a preser vação ambiental:

- Porcentagem de impermeabilização dos terrenos. Nas ảreas internas aos lotes serão definidas taxas de ocupação, de forma a serem preservadas äreas mais extensas em condiçāo natural, nos locais de maior valor ambiental. o controle da impermeabilização de verả estender-se, também, às àreas exteriores aos lotes, e de uso comum.

- Definição de densidades populacionais, em funçăo da capacidade de ocupação do local e da disponibilida de dos serviços de infra-estrutura. Estas densidades são conseguidas atravēs de formas indiretas,tais co mo: dimensōes minimas para os lotes, em função do uso e das características do meio; nümero de habita çōes por unidade de ärea; nümero de empregados por ărea ocupada pela atividade dos mesmos, etc. 
- Altura e volume das edificaçóes, estabelecidos atra vés do coeficiente de aproveitamento, taxa de ocupa ção e indice de elevação, os quais deverão conside rar, entre cutros aspectos, a circulação do ar, a i luminação, a insolação e a preservação da paisagem natural.

- Porcentagem de àreas livres ou destinadas aos equi pamentos de uso püblico. A escolha destas äreas de verä ser orientada de modo a garantir a preservação de determinados locais, possibilitar isolamentos (barreiras) ou facilitar a circulação do ar.

- Recuos mínimos das edificaçōes, com vistas a garan tír a ventilação, a insolação, a iluminação e o isó lamento de outras atividades, bem como possibilitar a adoção de soluções individuais de destinação de resíduos líquidos no solo.

Neste trabalho, jā definimos alguns índices urbanís ticos a serem aplicados em diversas situações, com o objetivo de preservar a qualidade ambiental. Huitos outros poderão ser esta belecidos, em função das características pröprias de cada recur so.

c) Transferència de densidades

A preservação de determinadas àreas é conseguida ut lizando-se a técnica da transferência de densidades, a qual con siste na permissão para o adensamento de edificaçōes nas zonas de características mais favoráveis à ocupação urbana, em troca da não utilização, ou uso de modo menos intenso, dos locais mais sensíveis do ponto de vista ambiental.

Assim, consegue-se que determinadas äreas permaneçam livres, mantendo-se a densidade total requerida para uma zona es pecífica.

Um exemplo desta tëcnica estä indicado na FIGURA 6.4, onde mostramos dois modos de parcelamento do solo nas märgens de Lm curso d'ägua. No primeiro caso, os lotes têm äreas aproxima das, enquanto que na segunda alternativa hä uma diminuição grada tiva de suas dimensões com o afastamento em relação ao corpo d'ä gua. Observa-se uma melhor utilização do solo no segundo caso, 
tendo sido projetada, inclusive, uma faixa de proteção. 0 nümero total de lotes é o mesmo nas duas situações (45 lotes).

Esta tēcnica pode ser utilizada para a proteção de ou tras äreas de valor ambiental, utillzando-se inclusive a forma de adensamento através da ocupaçäo vertical, nos locais de carac teristicas naturais favorávels e com serviços de infra-estrutura satisfatörios.

\section{d) Desapropríação}

A aquisiçāo de āreas pelo Poder Püblicoē, sem düví das, o meio mais eficiente de proteção. Áreas de valor paisagís tico e/ou ecológico têm os seus usos mais facilmente controlados quando sāo de propriedade püblica.

No entanto, devemos reconhecer que isto nem sempre é possivei devido aos custos de aquisição, multas vezes impraticá veis aos Municípios.

Mesmo assim, é indispensāvel que āreas a serem desti nadas à recreação, aos equipamentos comunitaärios, à proteção pai sagística e ecolögica, ou ao uso público em geral, sejam declara das de utilidade püblica para fins de desapropriação gradativa, dentro das possibilidades do Poder püblico.

Multas äreas sāo incorporadas ao patrimōnio municipal na aprovação de loteamentos, conforme veremos a seguir:

e) Controle do parcelamento do solo

A lei de loteamentos é um dispositivo de muito valor para o controle da ocupação do solo. Atravēs da aprovação de pro jetos de parcelamento do solo, o município pode exigir uma dís tribuição adequada dos lotes, equipamentos e vias públicas, no sentido de preservar a qualidade ambiental.

Na aprovação de loteamentos podem ser disciplinados, através de lei especifica: dimensōes mínimas dos lotes; taxas de ocupaçäo; áreas a serem destinadas à recreação e aos outros usos comunitários; dimensōes de vias públicas; infra-estrutura mínima exigida.

Compete ao örgão aprovador dos projetos de loteamen tos orientar o parcelamento da ärea de modo a garantira áreas li vres, internas e externas aos lotes, visando o controle da ero são e da infiltraçāo da àgua; uma melhor distribuição dos espe 
ços livres de uso comum; a manutenção das condições de drenagem; a adoçāo de faixas de preservação de recursos naturais; a previ säo de densidades compatíveis com a capacidade de utilização do local; o controle do movimento de terra, cortes e aterros; o tra çado das vias públicas de acordo com a topografia do local.

Assim, alēm da existência de legislação adequada, è importante o controle na aprovação dos projetos, visando orien tar o parcelamento do solo.

Como exemplo, podemos citar as áreas livres. Normalmen te, as leis de uso-ocupação do solo exigem a destinação de uma determinada porcentagem da ärea total a lotear, para espaços li vres. Cabe ao örgão municipal responsável pela aprovação do pro jeto, orientar a localização destas äreas, associando-as, por exemplo, à proteçāo das märgens de coleçōes superficiais de à gua, à preservação dos caminhos naturais de escoamento da àgua,à circulação do ar na cidade ou ao isolamento contra a propagação de poluentes atmosféricos ou de ruídos.

observa-se, quando não hā este controle na aprovação, a destinação de terrenos para espaços livres sem a mínima condi çäo de aproveitamento ou situados em locais onde terão pouca in fluência na preservaçāo da qualidade ambiental da cidade como um todo.

outro exempló de orientação do parcelamento do solo estä indicado na FIGURA 6.5. No primeiro desenho, a distribuição das vias públicas e dos lotes näo considerou a topografia da á rea nem os aspectos de drenagem natural. No segundo, observa-se uma adequaçäo do traçado às características naturais do local, - que, com certeza, resultará numa melhor utilizaçäo da área.

f) Dotaçäo de infra-estrutura

Já dissemos que a infra-estrutura existente em uma ci dade deve ser um elemento orientador da definiçāo das suas densi dades de ocupação. Por outro lado, pode-se encorajar o desenvol vimento de āreas propícias, atravēs da dotação de infra-estrutura, tais como, vias de acesso, iluminação, serviços de āgua e es goto, transporte, etc., assim como não incentivar a ocupação de äreas sensiveis, näo executando tais serviços.

0 adensamento de edificaçōes, comentado anteriormen 

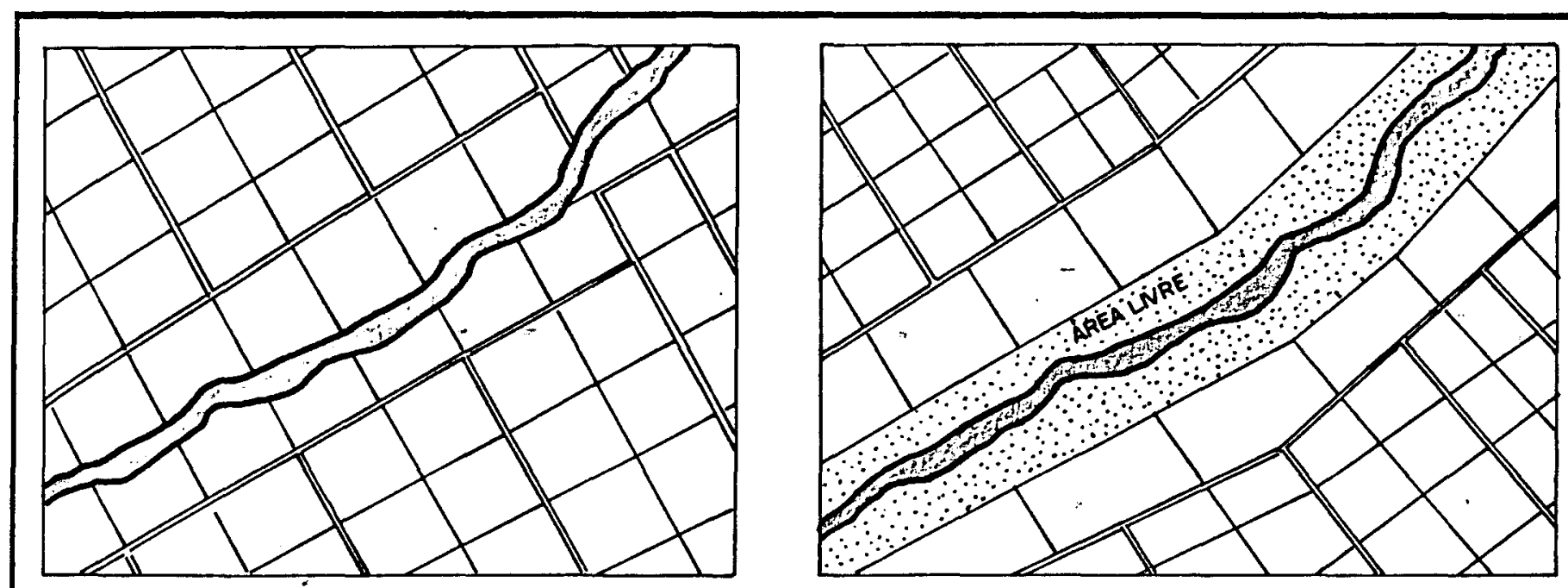

F I O URA 6.4

EXEMPLO ESOUEMÁTICO DE DOIS PARCELAMENTOS DIFERENTES

DE UMA MESMA ÁREA MANTENDO-8E A MESMA DENSIDADE

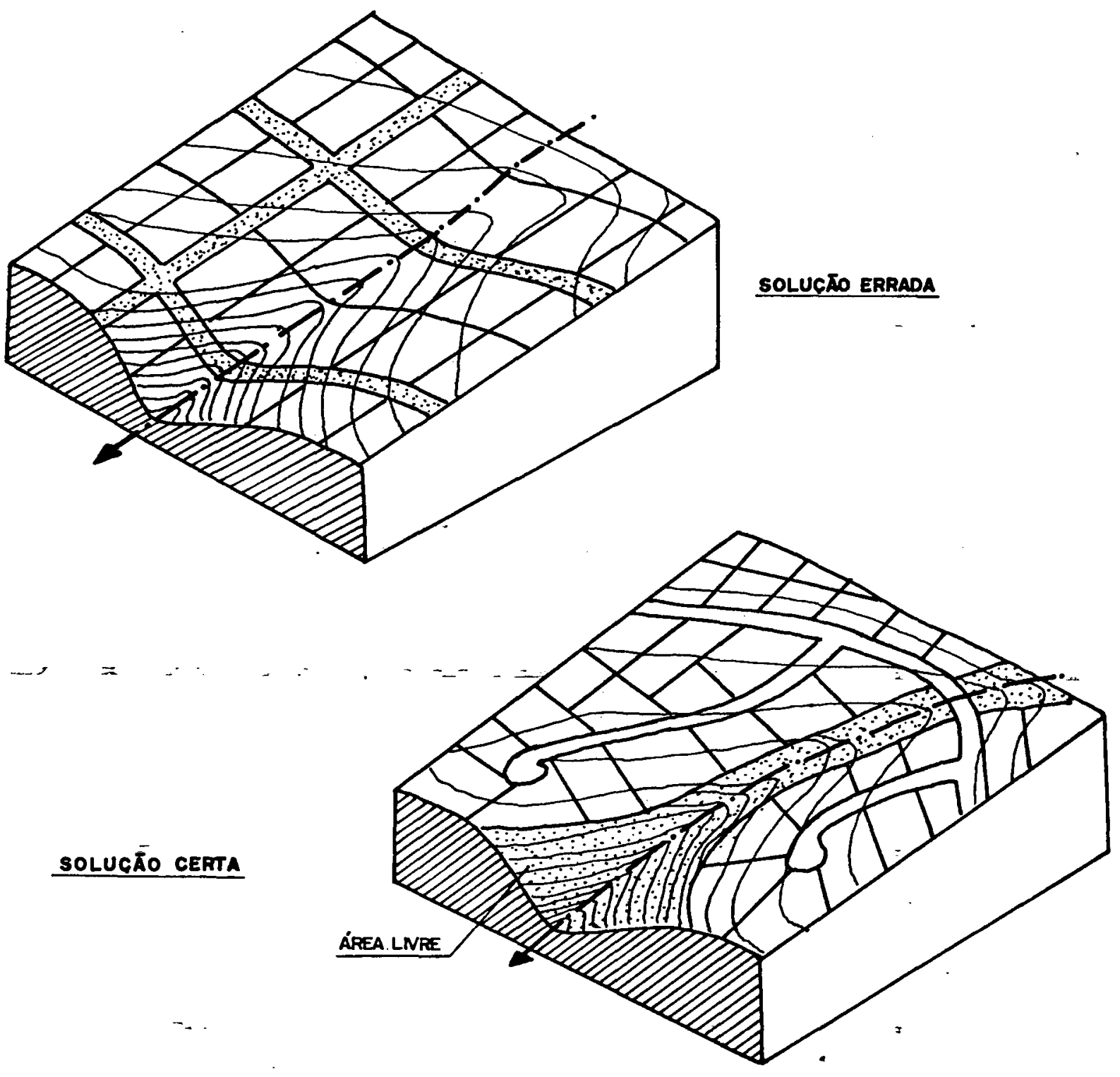

FIOURA 6.5

EXEMPLO DE PARCELAMENTO DO SOLO CONBIDERANDO ASPECTOS TOPOERÁFICOS E CONDICOEES DE DRENAOEM MATURAL DO TERREHO 
te, será incrementado pela existência de serviços públlcos nas à reas onde a ocupação possa ser mais intensa.

Por exemplo, a existência de uma rede coletora de es gotos com capacidade de receber contribuições razoāvels, possib i litará um maior adensamento de uma área propícia à ocupação urba na, ensejando a liberação de outras äreas de maior valor preser vativo.

Aqui $\bar{e}$ ressaltada, novamente, a importância da inte gração dos örgãos de planejamento urbano, de controle ambiental e de serviços püblicos em geral.

g) Outros regulamentos

Como parte das leis de zoneamento e loteamentos, ou constituindo-se legislação separada, outros regulamentos podem ser elaborados visando a preservação ambiental, tais como:

- Legislação específica de controle da poluição, com - estabelecimento de padrões de qualidade ambien tal, adaptando-se às normas federais existentes.

- Classificação das ãguas, de acordo com legislação da Secretaria Especial do Meio Ambiente.

- Regulamentos de controle de escoamento superficial, da erosão do solo e de movimentos de terra.

- Legislação de controle de desmatamentos e de preser vação vegetal, associada ao código florestal.

- Regulamento dispondo sobre os níveis de ruídos e o controle da poluição acūstica.

- Normas relativas ao controle da poluição visual.

- Administração integrada de bacias hidrográficas,com legislação específica para cada caso.

\subsection{3 - Aspectos econômicos e sociais}

Aliados ao aspecto físico-territorial, o disciplina mento do uso do solo urbano deve considerar os fatores económi cos e sociais. Mesmo quando se analisa sob o enfoque de preserva 
çäo ambiental, estes aspectos devem ser estudados.

Teoricamente, um exame sob o ponto de vista econōmico deve ser felto atravēs de uma análise custo-benefício, de forma a determinar um nível ötimo de controle ambiental. Este nível 으 correria quando a soma das despesas com o controle e com os cus tos dos danos resultantes da degradação ambiental atingisse o va lor minimo.

No entanto, podemos dizer que é impossivel efetuarse, com precisão, esta anālise. De acordo com SEWELL,"no planeja mento do ambiente, uma anālise de custo-benefício só pode servir como orientação grosseira e, mesmo assim, quem toma decisões de ve examinar com muito critério cada cálculo de benefícios e cus tos". (46)

Devido à multiplicidade de fatores a considerar, bem como por causa dos aspectos subjetivos dos mesmos, é difícil efe tuar-se uma anālise económica exata no planejamento urbano.

No entanto, devemos ter em mente os benefícios resul tantes para a população, quando se ordena a ocupação de determi nadas äreas, principalmente quando se leva em consideração os as pectos ambientais.

Os efeitos da degradação ambiental, principalmente na forma de poluiçāo, jä foram por demais constatados, refletindo-se sobre a saūde da população, com a consequente diminuicão da capa cidade produtiva da mesma, além de repercutir sobre o desenvolvi mento econōmico de uma localidade.

Acreditamos que isto seja suficiente para justificar uma ação visando a preservação da qualidade ambiental. Além do mais, pode-se dirigir o trabalho no sentido de não prejudicar o desenvolvimento econômico e social da comunidade.

- planejamento deve ser feito com o objetivo de disci plinar o uso-ocupação e não de criar empecilhos ao desenvolvimen to.

Pelo fato das indústrias serem fontes potenciais de poluição, não se pode querer proibir totalmente a sua implanta ção. O desenvolvimento industrial tambēm pode significar qualida de de vida, pelos inümeros benefícios resultantes. Assim, o que deve ser feito é uma distribuicão adequada das fábricas em uma cidade ou região, considerando aspectos ambientais.

o planejamento deve ter um carāter de disciplinamento 
do uso do solo, permitindo a ocupação de äreas em função

das suas características ambientais.

Algumas técnicas de compensação podem ser adotadas vi sando atenuar alguns efeitos economicos que possam ser aponta dos, como consequência da preservação de ãreas para a proteção ambiental. Por exemplo:

- As äreas a serem preservadas às märgens de cursos d'ägua, ou visando outro tipo de proteção,podem ser computadas dentro da porcentagem dos terrenos a per manecerem como ärea livre, e exigida, normalmente, na aprovação de loteamentos.

- Pode-se permitir o adensamento de determinadas zo nas, onde as condições de ocupação são mais favorä veis, em troca da utilização, de forma menos inten sa, de outros locais. A FIGURA 6.4 è um exemplo, on de, para uma mesma ārea, foi mantida a mesma densi dade, mas em parcelamentos diferentes.

- A preservação de āreas verdes ou de valor paisagís tico pode induzir a uma valorização natural dos ter renos vizinhos.

- Areas preservadas podem ser utilizadas como locais de recreação, com grande beneficios sociais.

- A preservaça da qualidade da ägua de mananciaís de abastecimento humano e de fābricas significa uma re dução nos custos dos tratamentos, resultando em á gua potável mais barata, e produtos industrlaliza dos de menor custo.

- Através de incentivos diretos ou indiretos pode - se favorecer a ocupação de determinadas äreas. 0s in centivos diretos podem ser abatimentos em impostos a pagar, enquanto que os indiretos podem ser, por exemplo, a dotação de uma infra-estrutura que indu za o desenvolvimento para os locais desejados.

Estes são alguns exemplos de como encarar economica mente uma política de preservação ambiental. No entanto, devemos ressaltar que o objetivo principal deve ser o bem estar físico, mental e social do homem, o qual não é facilmente computado sob 
- ponto de vista econômico.

6.2 .4 - Recursos humanos e educação ambiental

Os mültiplos aspectos compontentes do disciplinamentodo uso do solo urbano exige a particlpáçăo de uma equipe mult profissional relativamente grande.

Alēm dos tēcnicos jä normalmente envolvidos com o pla nejamento urbano, alguns outros precisam participar da equipe, quando este trabalho é feito visando a preservação ambientad. As sim, no planejamento do setor físico-territorial deverão traba lhar arquitetos, engenheiros civis, engenheiros sanitaristas, en genhel ros agrónomos, geógrafos, hidrólogos, ecólogos, urbanistas, meteorologistas, geölogos, etc. O setor econômico social deverá ser desenvolvido por demögrafos, sociólogos, estatísticos, econo mistas, psicológos, assistentes sociais, bacharéis em Direito, en tre outros.

o importante é que haja uma integração perfeita entre os profissionais considerados planejadores e aqueles com forma ção bāsica sanitarista.

Devemos reconhecer que poucos municípios no Brasil poderäo compor uma equipe com todos os profissionais enumeradosacima. No entanto, esta deficiencia poderá ser contornada atra vës da participação dos Estados no trabalho dos Municípios. As sim, uma equipe a nível estadual elaboraria os planos de Uso-ocu pação do Solo dos Municípios que não dispusessem de pessoal para isto, cabendo ao poder local a implantação dos mesmos, atravēs de uma equipe reduzida.

outro aspecto a considerar na preservaçäo do meio am biente é a participação da comunidade no processo. E necessäria a formação de uma consciência de que não só o poder püblico é responsāvel, mas tambēm toda a população deve trabalhar pela ma nutenção da qualidade de nosso ambiente de vida.

o processo educativo representa, assim, papel de gran de valor em qualquer atividade de preservação ambiental.

A Secretaria Especial do Meio Ambiente (SEMA) definiu a Educação Ambiental como um "instrumento de tomada de conscienn cia do fenômeno do desenvolvimento e suas implicaçöes ambientais 
e de transmissão de conhecimentos, habilidades e experlèncias que permitam ao homem atuar eficientemente no processo de manu tenção ou recuperação do equilibrio ambiental, de forma a manter a qualidade de vida condizente com suas necessidades e aspira çōes". (36)

Este mesmo trabalho da SEMA enfatizou tambēm alguns aspectos que caracterizam o processo de Educaçäo Ambiental:

"Enfoque global e integrado - a Educação Ambiental de verā considerar o ambiente ecológico em sua totalida de: o político, o econômico, o tecnolöglco,o social, - legislativo, o cultural e o estētico; no que se re fere à educação formal, não poderá ser mantida a tra dicional fragmentação dos conhecimentos ministrados atravës de disciplinas escolares consideradas como compartimentos estanques":

"Participação - Educação Ambiental deverä estender-se à toda a comunidade proporcionando-lhe uma tomada de consciência e consequente participaçāo no equaciona mento dos problemas ambientais vivenciados":

"Adequaçăo e continuidade - os diversos aspectos do ambiente variam no tempo definindo novas configura ções biofísicas e novas estruturas socials e cultü. rais e, portanto, novas problemáticas. A Educação Am biental deve adaptar-se permanentemente a elas, para a elas responder adequadamente".

o trabalho da SEMA caracterizou multo bem o processo de Educaçāo Ambiental, o qual deve, alēm de proporcionar uma to mada de consciencia, conseguir a participaça efetiva de todos. A Educação deve ser, portanto, um instrumento de mudança.

Qualquer plano de preservação ambiental deve envolver toda a populaçäo, induzl.ndo-a ao uso racional dos recursos natu rais. Esta participaça deve acontecer nas diversas fases do pla no, desde a elaboraçāo, atē a execução e avaliaçăo.

Acreditamos que somente assim poderão ser conseguidos a manutenção e a recuperação do equilíbrio natural, proporcionan do a todos a qualidade ambiental desejada. 
7. Resumo das principais recomendaçöes

Com o objetivo de facilltaf o manuselo deste trabaino pelos Interessados, agrupamos nos QUADROS 7.1 a 715 as princl. pais recomendăções visando o controle da poluição do solo, da ä gua, do ar e acústica bem como objetivando a ṕreservação dos re cursos de valor palsagístico; ambiental e cultural.

os citados Quadros Indicamj tambêm, os trechos do tra balho onde são feitas referências äs recomendações, nós quals pó derāo ser encontradas informaçōes mais detalhadas sobre as mes. mas.

Estes Quadros estāo assim distribuidos:

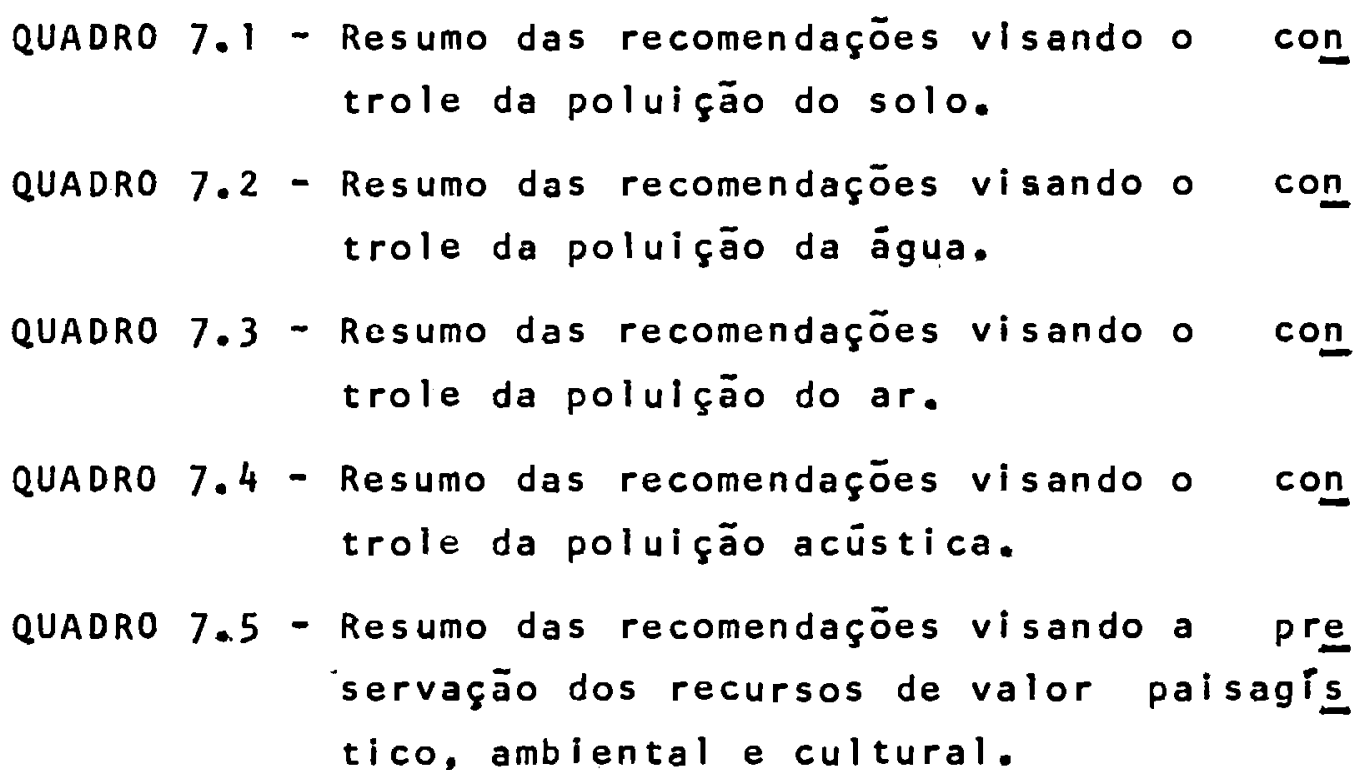


QUADRO 7.1

Resumo das recomendações visando o controle da poluição do solo

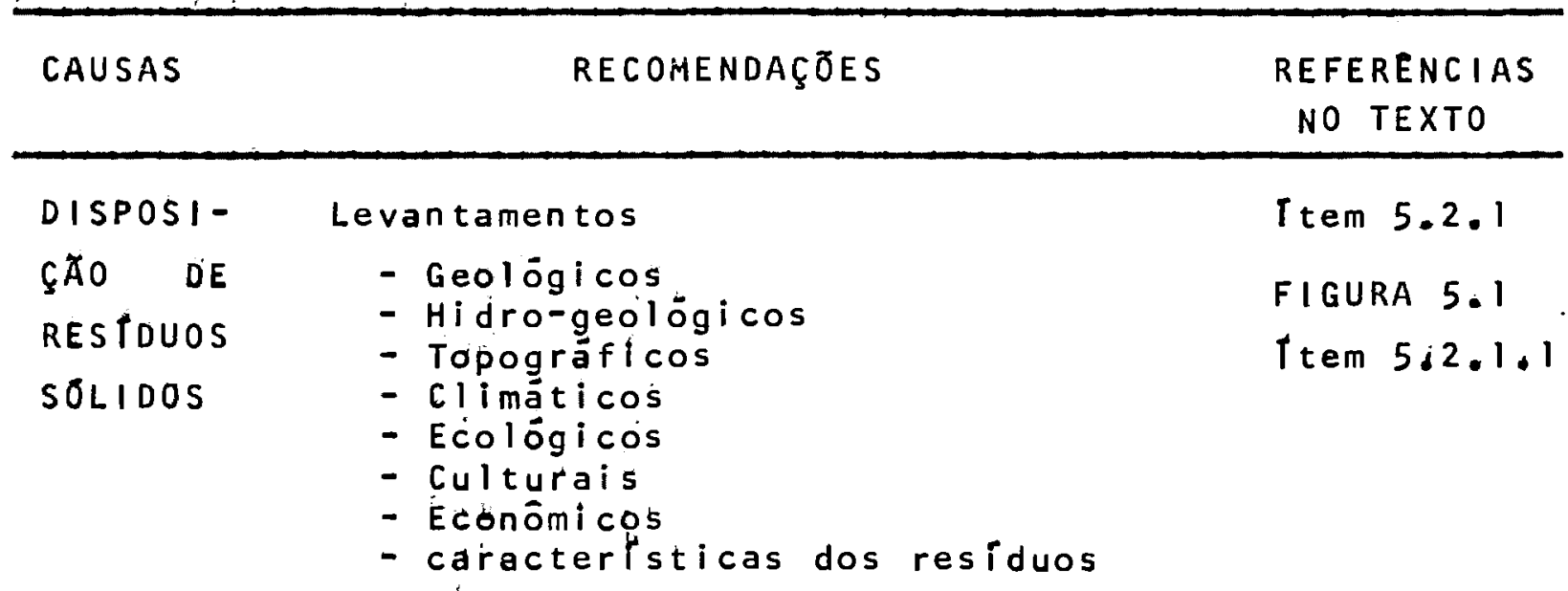

Posictonamento

a) Em relação à ãrea urbana

Ttem 5.2 .1 .1

- Sentido conträrio aos ventos predominantes

- Isolado de zonas residenciais, recreacionais e outras

- Evitando intensa circulação de veículos em zonas residenciais

- Considerando aspectos econômi $\cos$

b) Em relação às coleções superfici ais de àgua:

Resíduos municipais:

Mínimo: $50 \mathrm{~m}$

Recomendāvel: $300 \mathrm{~m}$

Resíduos industriais:

Mínimo: $1.000 \mathrm{~m}$

Recomendável: estudo mais deta lhado

c) Em relação ao lençol freātico:

Mínimo: $1,50 \mathrm{~m}$

Outros aspectos a considerar

T tem 5.2.1.1

- Poluição visual. Barreiras natü rais ou artificiais

- Produção de ruídos

- Maus odores eventuais

Outras medidas de controle

- Material de cobertura adequado

Ttem 5.2.1.

- Desvio de águas de escoamento su perficial

- Drenagem e tratamento de líquidos de percolação

- Drenagem de gases

- Impermeabilização do fundo e pare des laterais

Ttem 5.2.1.1 QUADRO 5.2 
QUADRO 7.1 (continuação)

CAUSAS

RECOMENDAÇÕES

REFERENCIAS

NO TEXTO

DISPOSI-

CAOO DE

RESTDUOS

LTQUIDOS

E LODOS

\begin{abstract}
EROSAOO DO
\end{abstract}
SOLO

\section{Levantamentos}

Ver recomendações relativas aos síduos sölidos

Posicionamento

- Em relação aos recursos hídricossuperficiais e subterrāneos:

Ver recomendaçōes relativas aos resíduos sölidos

- Em relação à àrea urbana

Afastamento minimo de $1.000 \mathrm{~m}$ de nücleos habitados

Afastamento mínimo de $400 \mathrm{~m}$ de residências isoladas

Considerar local de lançamento do efluente

Direção conträrija aos ventos predominantes (para lagoas a naerōbias)

\section{Levantamentos}

- Topografia

- Drenagem das águas superficiais

- Características do solo

- Vegetação

Controle

a) Ocupaçāo do solo Decllvidade Taxa de Ocupação

$\begin{array}{rlr} & <5 \% & \leqslant 90 \% \\ 5 \text { a } 15 \% & \leqslant 60 \% \\ 15 \text { a } 30 \% & \leqslant 30 \% \\ & >30 \% & \leqslant 10 \%\end{array}$

b) Faixas de preservação às märgens de coleções superficiais de ăgua

c) Preservação de solos sujeitos à erosäo

d) Preservação do escoamento natu ral das äguas

e) Preservaçăo da vegetaçāo natural

f) Outras medidas: proteçäo e redu ção das āreas expostas à erosäo; drenagem ou retençäo de äguas de escoamento superficial; constru ção de vias acompanhando o con torno natural do terreno.
Ttem 5.2.1

Ttem 5.2.1.1 FIGURA 5.2

Ttem $5.2 \cdot 1.2$

Ttem 5.2 .2

P tem 5.2 .2

FIGURA 5.3

Ttem 5.2.02

Ttem 5.3.3.1

FIGURA 5.6

FIGURA 5.7

T tem 5.2.2

T tem 5.2 .2

FIGURA 5.4

Ttem 5.2.2

Ttem 5.2 .2 
QUADRO 7.2

Resumo das recomendações visando o controle da poluiçäo da ăgua

CAUSAS

RECOMENDAÇðES

REFERENCIAS

NO TEXTO

INFILTRA

ÇÃO DE

ESGOTO -

NO SOLO

\section{Levantamentos}

- Infra-estrutura sanitāria existente

Ttem 5.3 .1

- Características geolögicas do ter reno

- Capacidade de absorção do solo

- Profundidade do lençol freático

- Direção e taxa de escoamento da à gua subterrânea

- Declividade do terreno

- Distância para corpos superficiais de ägua e poços

- Profundidade da camada de rocha im permeävel

- Elaboração de Mapa indicando zonea mento de áreas para uso de fossas sépticas

T tem 5.3 .2

Ttem 5.3.2

Ttem 5.3 .2

Ttem 5.3 .2

Ttem 5.3 .2

Ttem 5.3 .2

r tem 5.3 .2

I tem 5.3 .2 FIGURA 5.5

Medidas de proteção do lençol freātico e de äguas superficiais

a) Absorçāo do terreno: não recomen- Ttem 5.3.2 dado o uso de fossas para os solos com coeficiente de absorção superior a $1401 / \mathrm{m}^{2} / \mathrm{dia}$ ou inferi or a $25 \mathrm{l} / \mathrm{m}^{2} / \mathrm{dia}$

b) Profundidade do lençol freätico:- Ttem 5.3.2 distāncia mínima de $1,50 \mathrm{~m}$ entre - fundo do sistema de infiltração e o nível máximo do lençol

c) Poços devem situar-se na parte - Ttem 5.3 .2 mais alta do lote

d) Sistemas de fossa sëptica devem Ttem 5.3.2 ser usados com cautela em terre nos com declividade superior a $20 \%$

e) Distāncia entre sistemas de absor item 5.3 .2 ção de esgoto no solo e poços ou QUADRO 5.5 coleçöes superficiais de água : mínimo de $30 \mathrm{~m}$

f) Uso do solo em função da infra-es trutura sanitäria existente

- Uso-ocupação do solo em função Ttem 5.3.1 da infra-estrutura sanitária

- Densidades compatíneis com a in fra estrutura sani tāria

- Dimensões mínimas e índice de o Ttem 5.3 .2 cupação de lotes em funçäo da QUADROS 5.7 e infra-estrutura sanitäria $\quad 5.8$ 
QUADRO 7.2 (continsaçāo)

CAUSAS

RE COMENDAÇÕES

REFERENCIAS

NO TEXTO

FONTES -

NÃO LOCA-

LIZADAS
Medidas de controle

a) Redução da quantidade de ägua de Ttem 5.2 .2 escoamento e da erosão

- Cobertura vegetal adequada

- Preservação do escoamento natural das àguas

- Uso do solo em função da declivi dade

Ttem $5 \cdot 3 \cdot 3 \cdot 1$

FIGURA 5.4

- Dispositivos para desvios ou

tençäo do líquido escoado: vale

tas, diques, bacias de acumulação e sedimentação

b) Faixas de Proteção

Ttem $5.3 \cdot 3.1$

- Faixas de largura variāvel, função das características locais

- Faixas de largura fixa:

FIGURA 5.6

FIGURA 5.6

1: FAIXA (DE PROTEÇÃO)

FIGURA 5.7

Largura mínima, a partir do nível FIGURA 5.8 máximo de água:

1) Agua e esgoto existentes - re comendada pelo cōdigo flores tal ou necessäria à drenagem

2) Esgoto não existente

Cursos d'ägua com largura até $60 \mathrm{~m}: 30 \mathrm{~m}$

Cursos d'ägua com largura supe rior a $60 \mathrm{~m}: 30$ a $100 \mathrm{~m}$, de acor do com o Código Florestal

Usos: Atividades recreacionais e conservacionistas, sem grandes a teraçōes no estado natural.

20 FAIXA (OE CONTROLE)

Largura mínima: $100 \mathrm{~m}$

Usos: qualquer tipo, desde que -

náo cause poluição
Áreas dos lotes:

Taxa de ocupação: $\leqslant 0,30$

3: FAIXA (DE COHTROLE)

Largura minima: $200 \mathrm{~m}$

Usos: qualquer tipo, sem causar polvi çăo

Areas dos lotes: $\geqslant 500 \mathrm{~m}^{2}$

Taxa de ocupação: $\leftarrow 0,50$ 


\section{QUADRO 7.2 (continuação)}

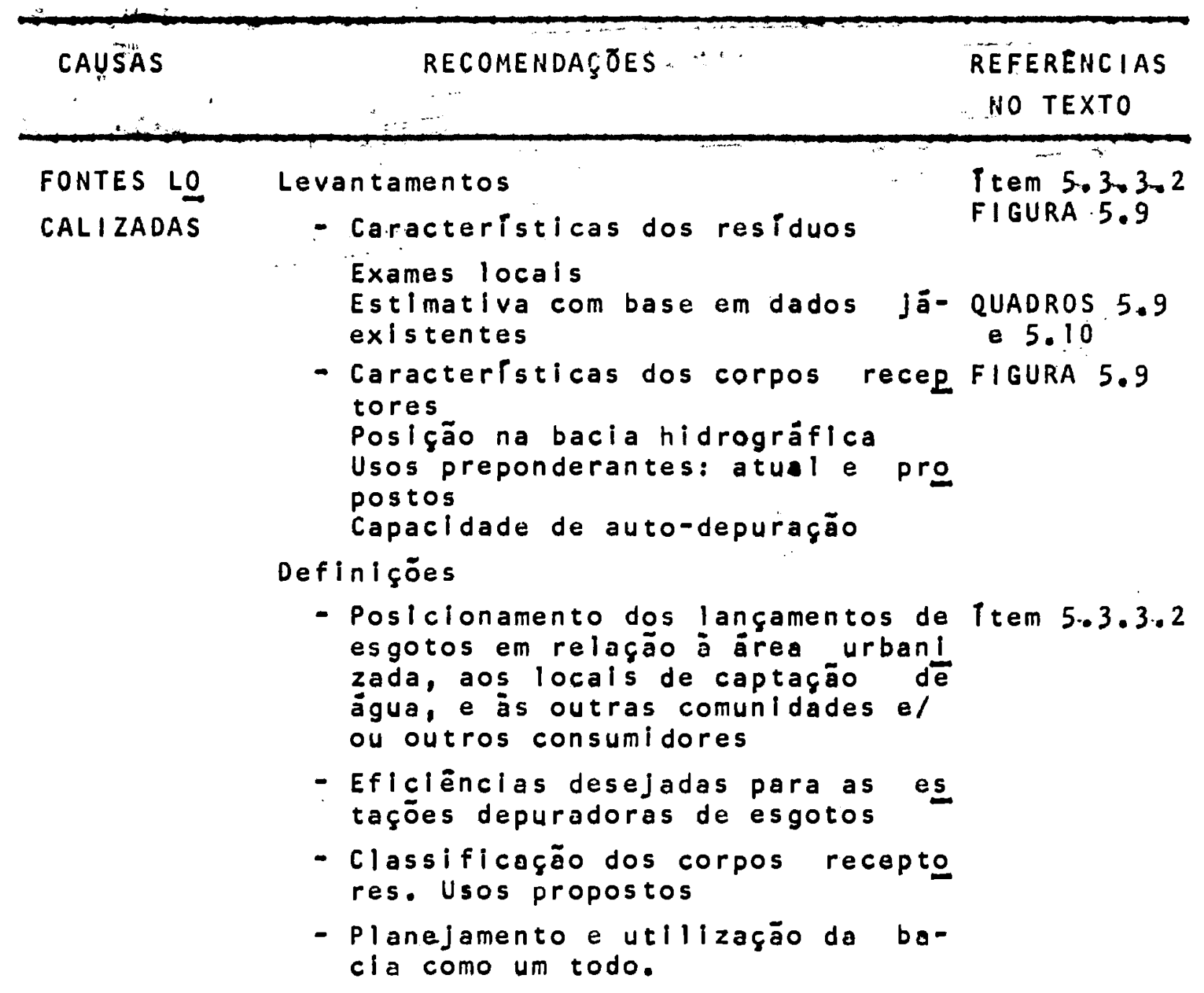


QUADRO 7.3

Resumo das recomendaçōes visando o controle da poluição do ar

$\begin{array}{lc}\text { CAUSAS RECOMENDAÇOES } & \text { REFERENCIAS } \\ & \text { NO TEXTO }\end{array}$

FONTES -

ESTAC IO-

NÁRIAS
Levantamentos

a) Condições existentes de poluição

b) Potencial de poluição. Estimativa da carga poluidora

Determinaçoes locals

Estimativa com base em dados jä existentes

Classificação das indüstrias em fünção do potencial de polu ição

c) Condiçōes de dispersão de poluen Ttem 5.4.1.2 tes

- Velocidade e di reção dos ventos. Rosa dos ventos

- Estabilidade atmosférica

- Modelos de dispersão

Modelo da Caixa

Modelo da pluma gaussiana

Modelos de simulaçăo numēri ca

- Curvas de concentração de polu antes

d) Condições topogräficas

e) outros aspectos ambientais. Circu lação do ar; äreas verdes

Medidas de controle

a) Estabelecimento de padrões a se rem alcançados

b) Controle na fonte

c) Localização adequada das fontes Ttem 5.4 .1 .3 em termos de condiçōes climáticas e topogrāficas

d) Afastamento de àreas de habita ção, saüde, educação, recreação

e de usos sociais:

- Função das características lo Ttem 5.4.1.3 cais

- Controle do uso do solo nas proximidades de fontes. Faixas sanitärias:

Indūstrias GRANDE poluidoras:

$$
\geqslant 1.500 \mathrm{~m}
$$

Indústrias MEDIO poluidoras:

$\$ 500 \mathrm{~m}$
Ttem $5.4 \cdot 1.3$

a 5.13

QUADROS 5.14

a 5.17

FIGURA 5.10

FIGURA 5.11

FIGURA 5.12

Ttem 5.4 .1 .3

$\operatorname{ten} 5 \cdot 4 \cdot 1 \cdot 3$

Ttem 5.4.1.1

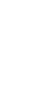

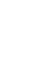


QUADRO 7.3 (continuaçāo)

\begin{tabular}{lc}
\hline CAUSAS & RECOMENDAÇOES \\
NO TEXTO \\
\hline
\end{tabular}

Indüstrias PEQUENO poluidoras:

$\geqslant 300 \mathrm{~m}$

Indüstrias LEVE poluidoras:

$\geqslant 100 \mathrm{~m}$

Indüstrias NAOO poluidoras:

$\geqslant 50 \mathrm{~m}$

- Indüstrias de características es Ttem 5.4.1.3 peciais - a critério de estudo de talhado

e) Avallação permanente das condiçōes- FIGURA 5.13 de poluição atmosfërica

FONTES

MOVEIS
Levantamentos

Ttem 5.4 .2

- Estimativa da carga poluidora. Emis são de poluentes por veículos

- Determinação de áreas críticas

- Aspectos ambientais

Medidas de controle

- Controle da emissão nos veículos

- Incentivo ao uso do transporte cole tivo

- Mudanças no sistema de transporte:melhoria e ampliação dos sistemas de transporte coletivo

- Redução do número de viagens: mistu ra ordenada dos usos do solo, visañ do reduzir o número e percursos de viagens residência - trabalho e/ououtras atividades

- Melhoria do fluxo de veículos

- Disciplinamento do uso do solo em figura 5.15 torno de vias de grande movimento. Afastamento de usos sensiveis (resi) dências, escolas, recreaçäo, hospī tais, etc.) destas vias; isolamento por barreira de vegetação ou outra. 
QUADRO 7.4

Resumo das recomendaçōes visando o controle da poluição acüstica

- Principais fontes de ruídos

- Niveis de ruídos existentes

- Determinação de äreas críticas

- Estimativa da emissão de novas fontes

- Aspectos ambientais favoräveis ou não à propagação

FONTES - Medidas de controle

ESTAC 10-

- Estabelecimento de padrões, especifi NARIAS cando níveis desejáveis de ruídos

- Controle nas fontes: limitação dos ni veis de emissão de ruídos; fixação de horārios de funcionamento de equipa mentos ruidosos

- Isolamento das fontes de barulho

- Isolamento dos receptores

- Adoção de medidas preventivas:

- Afastamento entre fonte e receptor

- Barreiras contra a propagação do som. Vegetação densa.

- Disciplinamento do uso do solo em torno. de fontes de ruídos

TRÁFEGO- Hedidas de controle

DE VETCU - Controle da emissão de ruídos nos veí LOS culos

- Restriçōes ao träfego pesado em deter minadas áreas e horários

- Incentivo ao transporte coletivo

- Melhoria do fluxo de veículos

- Construção de barreiras contra a pro flguRA 5.18 propagaçäo do som: elevaçöes do tér reno; paredóes de alvenaria, concretō ou madeira

- Disciplinamento do uso do solo às már gens de vias de grande circulaçāo dē veículos

- Projeto adequado de vias, de modo atenuar a propagação do ruído

TRÁFEGO- Medidas de controle

a FIGURA 5.19

Ttem $5.5 \cdot 2 \cdot 3$

\section{AEREO}

- Redução do barulho na fonte

- Orientação das pistas e trajetórias de modo a atenuar a incidência de ruí dos na äreas sensíveis (residencias? escolas, hospitais, de recreação, etc.) 
QUADRO 7.4 (continuação)

\begin{tabular}{rr} 
RECOMENDAÇOES & REFERENCIAS \\
& NO TEXTO \\
\hline
\end{tabular}

- Disciplinamento do horário de funcio namento de aeroportos

- Disciplinamento da localização de he llportos: distantes de hospitals, es colas, bibliotecas, etc.

- Construção de barreiras físicas à propagação do ruído, aproveitando condiçós topogräficas ou outras ca racteristicas naturais

- Disciplinamento do uso do solo em torno de aeroportos:

- Determinaçäo do N.E.F. (Noise Ex posure Forecast) - Uso residenct al em locais exteriores à linhā de N.E.F. igual a 30

- Afastamento entre fontes e áreas FIGURA 5.21 residenciais e de outros usos sensíveis: superior a $2.000 \mathrm{~m}$

- Elaboração do Plano de Uso do So lo na vizinhança de aeroportos. 


\section{QUADRO 7.5}

Resumo das recomendações visando a preservação dos recursos de valor paisagístico, ambiental e cultural

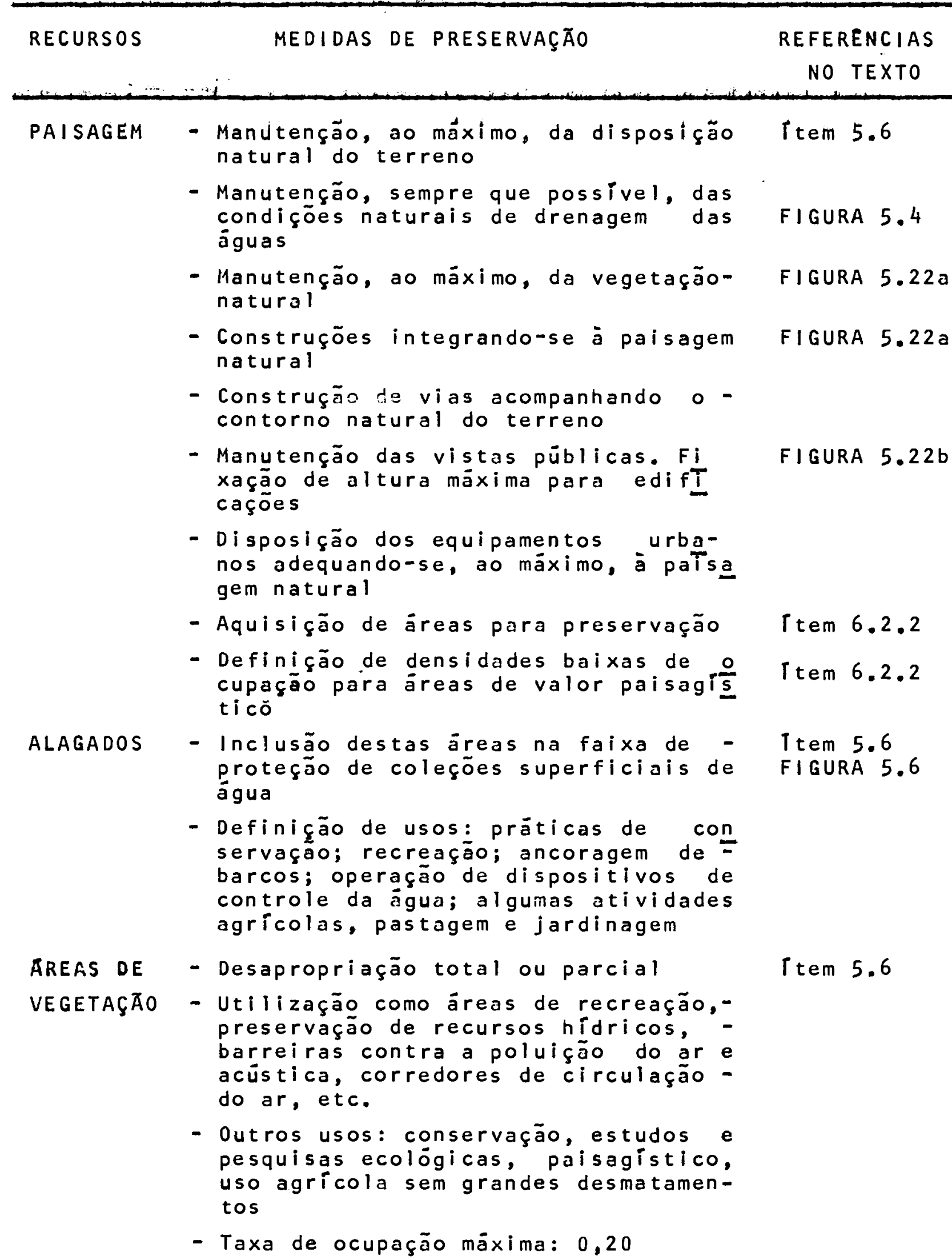


QUADRO 7.5 (continuação)

\begin{tabular}{|c|c|c|}
\hline RECURSOS & MEDIDAS DE PRESERVAÇĀO & $\begin{array}{c}\text { REFERENCIAS } \\
\text { NO TEXTO }\end{array}$ \\
\hline ENCOSTAS & $\begin{array}{l}\text { - Disciplinamento do uso do solo. Taxa } \\
\text { de ocupaça em funça da declividade } \\
\text { (Ver recomendaçöes relativas ao con } \\
\text { trole da erosão) } \\
\text { - Definlção de usos: preservação da ve } \\
\text { getação, äreas de recreação, usos } \\
\text { baixa taxa de ocupação (em função da } \\
\text { declividade) }\end{array}$ & $\begin{array}{l}\text { Ttem } 5.2 .2 \\
\text { FI GURA } 5.3 \\
\text { Ttem } 5.6\end{array}$ \\
\hline $\begin{array}{l}\text { AREAS DE } \\
\text { RECARGA } \\
\text { DE AQUT - } \\
\text { FEROS }\end{array}$ & $\begin{array}{l}\text { - Conservar livres, totalmente ou em } \\
\text { grande parte } \\
\text { - Definição de usos: recreação; composi } \\
\text { caão paisagística; outros usos coma } \\
\text { baixa taxa de ocupação: } 0,10 \text {, no mä } \\
\text { ximo }\end{array}$ & Ttem 5.6 \\
\hline $\begin{array}{l}\text { OUTROS - } \\
\text { RECURSOS }\end{array}$ & & \\
\hline $\begin{array}{l}\text { NATURAIS } \\
\text { OU DE VA } \\
\text { LOR HIS } \\
\text { TORICO - } \\
\text { CULTURAL }\end{array}$ & - Especificas para cada caso & Ttem 5.6 \\
\hline
\end{tabular}


1. ABOUT sound. Washington, D.C., U.S. Environmental Protection Agency, 1976, 45p.

2. Air pollution and the San Francisco Bay Area. 11.ed.San Francisco: Area Air Pollution Control District, 1977\& 51p.

3. AIRPORT nolse abătement platinling. Washington, D.C.,U.S. Envi ronmental Protection Agency, 1977. $11 \mathrm{p}$.

41 ANUARIÓ ESTATISTICO DO BRASIL. RIO de JanelHOd IBGEI Cantro Edtorials ig76

5. ASSUNçÃo, J.V. de - oplanejamento territorial aplicado no controle da poluição no Estado de São Paulo Sāo Paulo, CETESB, 1979

6. AZEVEDO NETO, J.M. \& LOTHAR HESS, M. - Tratamento de à guas residuárias. São Paulo. Separata da Revis ta D.A.E., 1970

7. BERANEK, L.L. - Noise and vibration control, New York, McGraw Hill Ed., 1971

8. BRAGDON, C.R. - Community noise ordinances: their evolution, purpose and impact. IN: $74 \mathrm{th}$ NATIONAL MEETING OF THE AMERICAN INSTITUTE OF CHEMICAL ENGINEERS, New Orleans, Louisiana, 1973

9. BRANCH, M.C. - Planning urban environment. Stroudsburg, Pennsylvania. Dowden, Hutchinson $E$ Ross, Inc.,1974

10. BRANCO, S.M. E ROCHA, A.A. - Poluicão, proteção e usos mültiplos de represas. São Paulo, Ed. Edgar Blucher, CETESB, 1977

11. BRIGGS, T.M. et al - Air pollution considerations in residential planning. Volume 1: Manual. Research Triangle Park, Noith Carolina, U.S. Environmental Protection Agency, 1974 
12. BRUNNER, D.R. E KELLER, D.J. - Sanitary landfill: design and operation. Washington, D.C., U.S. Environmental Protection Agency, 1972

13. CARPIGIANI, UBALDO - Preservação de recursos naturais: suporte técnico para legislação. Tese de douto ramento. Faculdade de Saúde Püblica, São Paulo, 1971

14. DEUTSCH, M. - Incidents of Choromium Contamination of ground water in Michigan. In: WATER QUALITY IN A STRESSED ENVIRONMENT. Minneapolis, Minnesota Burges Publishing Company, 1978

15. DORICH, LUIS - Planejamento urbano e abastecimento de àgua. In: LEITURAS de PLANEJAMENTO e URBANISMO. Rio de Janeiro, Instituto Brasileiro de Admi nistração Municipal, 1965

16. ENGRACIA DE OLIVEIRA, WALTER - Implicações sócio-econô micas, ambientais e de saüde dos resíduos söli dos. Rev. D.A.E., 120: $57-63,1979$

17. ENGRACIA DE OLIVEIRA, WALTER - Saneamento e Planificação. Tese para provimento do cargo de profes sor Catédrático. Faculdade de Saúde Pública, São Paulo, 1964

18. EPSTEIN, A.H. et al - Aguide for considering air quality in urban planning. Research Triangle Park;North Carolina, U.S. Environmental Protection Agency, 1974

19. ESTEVES, S.S. et al - Níveis de Poluição Sonora na Re gião da Grande São Paulo. São Paulo, CETESB,1979

20. FERRARI, C. - Curso de Planejamento Municipal Integra do. Urbanismo. São Paulo, Livraria Pioneira Editora, 1977

21. GATlEY, W.S. E FRYE, E.E. - Regulation of noise in urban areas. U.S. Environmental Protection Agency, 1971 
22. GEORGIA MOUNTAINS PLANNING AND DEVELOPMENT COMMISSION. Land Development Standards. At lanta,Georgia, 1974

23. GIANNESCHI, A. et al - Inventärio das fontes de polui ção no Estado de São Paulo. São Paulo,CETESB,1979

24. GOODMAN, WILLIAM I., ed. E FREUND, Eric C., ed. Principles and practice of urban planning. Washington, D.C., International City Managers' Association, 1968. $621 \mathrm{p}$.

25. HOME sewage disposal; special circular 212. Pennsylvania, The Pennsylvania State University, S.D. 21 .

26. IMHOFF, KARL - Manual de Eratamento de āguas residuárias. São Paulo, Editora Edgard Blucher Ltda., 1966

27. KORBITZ, WILLIAM E., ed. Urban public works administration, Washington, D.C., International City Managers'Association, 1976. $563 \mathrm{p}$.

28. LANDSBERG, H.E. - Climates and urban planning. In:URBAN CLIMATES. Geneva, World Meteorological Organiza tion. 1970

29. LANDSBERG, H.E. - Physical climatology. Du Bois, Pa., Gray Publ. Go., 1968

30. LEOPOLD, L.B. - Hidrology for urban land planning: A guidebook on the hydrologic effects of urban land use. U.S. Geological Survey Circular, 554, 1968

31. LOUREIRO, R.V. - Metodologia de efetuaça de levanta mentos visando a avaliação da carga poluidora dos resíduos líquidos industriais. Trabalho de Mestrado. Faculdade de Säüde Püblica, São Pau10,1974

32. MARCUS, M.G. E DETWYLER, T.R. - Urbanization and Environmente in perspective. In: URBANIZATION AND ENVIRONMENT. Belmont, Cali fornia, Duxbury Press 1972 
33. MEIRELLES, Hala - Direito Munictpal Brasilelfo. Săo Pau 10, Editora Revista dos Tribunais, 3a.ed.,1977

34. MESQUITA, A.L. de S. et al - Controle de emissão de fontes móveis no Estado de São Paulo, CETESB,1979

35. MINISTERIO DO INTERIOR. Legislação Básica. Secretaria Especial do Meio Ambiente. Brasília, 1976

36. MINISTERIO DO INTERIOR. Secretaria Especial do Meio Am biente. Educação Ambiental. Brasília, 1977

37. MOTA, F.S.B. - Aterro sanitärio e poluição da ägua. Tra balho de Mestrado. Faculdade de Saúde Pübli ca, São Paulo, 1974

38. NEFUSSI, NELSON - A poluição do ar no Estado de são Pau 10. In: CONGRESSO BRASILEIRO DE ENGENHARIA SE NITARIA, 8:. Rio de Janeiro, 1975

39. NEFUSSI, N. E GUIHARÃES, F. de A. - Curso sobre polui ção: Agua, Ar. (Apostila). Rio de Janeiro, Ins tituto Brasileiro do Petröleo, S.D.

40. NEW ENGLAND CONSORTIUM ON ENVIRONMENTAL PROTECTION.

Boston's tramsportation control plan... Washington, D.C., U.S. Environmental Protection Agency, 1975, 36p.

41. NOISE and its measurement. Washington, D.C., U.S.

Environmental Protection Agency, 1977

42. PARKER, H.W. - Wasterwater systems engineering.

Englewood Clift, New Jersey. Prentice-Hall, Inc., 1975

43. PLANO URBANTSTICO BÁSICO - Prefeitura Municipal de São Paulo, Grupo Executivo do Planejamento, São Paulo, 1969

44. ROMERO, J.C. - The movement of bacteria and viruses through porous media. IN: WATER QUALITY IN A STRESSED ENVIRONMENT. Minneapolis, Minnesota, Burgess Publishing Company, 1972 
45. SENGES, GiH. - Limpeza urbana: métodos e sistemas.

Rio de Janeiro, Instituto Nacional de Assistên cía aos Municípios, 1969

46. SEWELL; GịHd - Admínistracão e controle da qualidadeambiehtal. São Paulos E.P.U.; EdUSP,CETESB. 1978

47. STEVENJON Jr., G.M. - Hoise and the urban environment. In: URBANIZATION AND ENVIRONMENT. BelmOnt, Cali fornia. Duxbury Press. 1972

48. THUROW, C. et al - Performance controls for sensitive lands. A practical guide for local administrators. Chicago, American Society of Planning Officials. 1977

49. U.S.A. CITY OF EL PASO, TEXAS. Subdivision Ordinance. City Council, 1974

50. U.S.A. COUNTY OF WESTCHESTER. Dapartment of health. Rules and Regulations for the approval of plans for small sewage disposal systems, S.D.

51. U.S.A. DAVIDSON COUNTY, TENNESSEE. Metropolitan Health Department. Regulation Governing Private Sewage Disposal Systems in Metropolitan Nashville and Davidson County, Tennessee, 1974

52. U.S.A. ERIE COUNTY. Environmental Protection Plan:Erie County areas of natural significance. Erie County Metropolitan Planning Commission. 1977

53. U.S.A. MILLCREEK TOWHSHIP. Subdivision Ordinance. Millcreek Township, Erie County, Pennsylvania, 1965

54. U.S.A. NASHVILLE - DAVIDSON COUNTY. Airport Vicinity Plan: Metropolitan Nashville Airport. Metropolitan Planning Commission, 1977

55. U.S.A. NASHVILLE - DAVIDSON COUNTY. Natural Environmental Analysis. Planning lommission, Metropolitan Government Nashville, Tennessee, 1973 
56. U:S:A: WESTCHESTER COUNTY. Waste Treatment management plan. Final Report. Vol: 11, 1978

57. U.S. DEPARTMENT OF AGRICULTURE - Standards and specifications for soil erosion and sediment control in developing areas. College Park, Maryland. Soil Conservation Service. 1975

58. U.S. ENVIRONMENTAL PROTECTION AGENCY. Compilation of al pollutant emission factors. 2a. ed.0ffice of Air Quality Planning and Standards, Research Triangle Park, North Carolina, i973

59. U.S. FOREST SERVICE. Hydrologic Effects from Urbanization. 1969

60. VAZ OA COSTA, R. - Crescimento demogräfico e poluição do meio ambiente. Rio de Janeiro. BNH, 1973

61. VICTORETTI, B.A. - Contribuicão ao emprego de lagoas de estabilização como processo para depuracão de es gotos domésticos. São Paulo, CETESB, 1973

62. WOOD, CHRISTOPHER - Town planning and pollution control. Oxford Road, Manchester University Press, 1976

63. WORLD HEALTH ORGANIZATION. Environmental Health Aspects of Metropolitan Planning and Development. Technical Report Series n? 297, Geneva, 1965. 